\title{
A Phonological Study in the 'Phags-pa Script and the Meng-ku Tzu-yün
}

Miyoko Nakano

Faculty of Asian Studies in association with Australian National University Press

Canberra 1971 
This book was published by ANU Press between 1965-1991.

This republication is part of the digitisation project being carried out by Scholarly Information Services/Library and ANU Press.

This project aims to make past scholarly works published by The Australian National University available to a global audience under its open-access policy. 


\section{A Phonological Study in the 'Phags-pa Script and the Meng-ku Tzu-yün}

Oriental Monograph Series No. 7

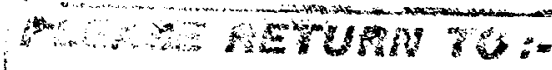

-

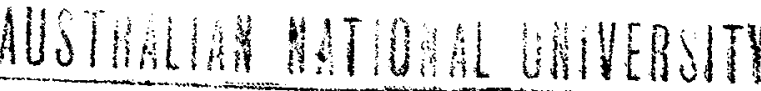

Publication date 17.9.71 


\section{Faculty of Asian Studies: \\ Oriental Monograph Series}

These monographs are a continuing series, on the languages, cultures, and history of China, Japan, India, Indonesia, and continental Southeast Asia.

1. A. H. Johns : The Gift Addressed to the Spirit of the Prophet (1965)

2. H. H. Dubs (compiled by Rafe de Crespigny) : Official Titles of the Former Han Dynasty (1967)

3. H. H. E. Loofs : Elements of the Megalithic Complex in Southeast Asia: An annotated bibliography (1967)

4. A. L. Basham (ed.) : The Papers on the Date of Kanișa (1969)

5. A. Yuyama : A Bibliography of the Sanskrit Texts of the Saddharmapundarikasūtra (1970)

6. I. de Rachewiltz and M. Nakano : Index to Biographical Material in Chin and Yuan Literary Works (1970)

7. Miyoko Nakano : A Phonological Study in the 'Phags-pa Script and the Meng-ku Tzu-yun (1971)

8. K. H. J. Gardiner : The Early History of Korea (1969)

9. R. de Crespigny : The Last of the Han (1969)

10. Frances D. M. Dow : Mandarin Phonetics. 2nd Edition (forthcoming)

11. D. N. Lorenzen : The Käpāilikas and Kālāmukhas : Two Lost Saivite Sects (forthcoming) 


\section{A Phonological Study in the 'Phags-pa Script and the Meng-ku Tzu-yün}

\section{Miyoko Nakano}

Faculty of Asian Studies in association with Australian National University Press

Canberra

1971 
(C) Miyoko Nakano 1971

This book is copyright. Apart from fair dealing for the purposes of private study, research, criticism, or review, as permitted under the Copyright Act, no part may be reproduced without the written permission of the publisher.

Printed by Southwood Press, Sydney, from type set by Sanyosha, Japan.

National Library of Australia Card no. and ISBN 0708104835

Library of Congress Catalog Card no. 76-173088 


\section{Contents}

Acknowledgments 1

Abbreviations 2

Introduction $\quad 7$

I A Biography of Bla-ma 'Phags-pa 24

II The 'Phags-pa Alphabet 39

III 'Phags-pa Orthography in Chinese Documents 59

IV The Sound System in the Meng-ku Tzu-yün

Appendix: 'Phags-pa Materials 134

Bibliography 147

$\begin{array}{ll}\text { Postscript } & 171\end{array}$ 


\section{ACKNOWLEDGEMENTS}

THIS paper is a preliminary to an intended Study in Middle Chinese Phonology, which I hope to complete within the next few years and which has for some time formed the major topic of my research. Generally speaking, the study of Middle Chinese still lags behind that of Ancient Chinese, which has been rapidly advanced by Professor $B$. Karlgren and other scholars, although even in Ancient Chinese studies there are still wide gaps.

The index to the whole body of characters in the Meng-ku Tzu-yün will be published separately in the near future, and it will include a table of the phonetic values of each character in comparison with Ancient Chinese and the Chung-yüan Yin-yün. This will, I hope, complement the Analytic Dictionary of Chinese and Sino-Japanese (Paris, 1923) compiled by Professor Karlgren, which deals very little with Middle Chinese.

In the course of this research, I have been much indebted to Professor E. G. Pulleyblank of the Department of Asian Studies of the University of British Columbia, who has given me a number of valuable suggestions and has encouraged me to publish this paper.

I should also like to express my sincere gratitude to Professor J. W. de Jong and $\mathrm{Mr}$ A. Yuyama of the Department of South Asian and Buddhist Studies of the Australian National University. They have given me constant support in the project of publishing this paper and have made many useful suggestions, especially on Sanskrit and Tibetan sources. I also owe a special debt of gratitude to Professor A. Tōdo of the University of Tōkyō, who has guided my studies in this field. Finally, I am most grateful to Dr A. Fraser and Dr K. H. J. Gardiner of the Australian National University for their help in improving my written English.

In making these acknowledgements, however, I intend in no way to disclaim my responsibility for the inadequacies and imperfections of this work.

M. Nakano

The Australian National University, Canberra. 4 April 1968. 


\section{ABBREVIATIONS}

$A A \quad=$ Acta Asiatica ( $=$ Bulletin of the Institute of Eastern Culture) (Tokyo)

$\begin{aligned} A M & =\text { Asia Major (Leipzig, later new series in London) } \\ A O & =\text { Acta Orientalia (Leiden, later Copenhagen) } \\ A O H & =\text { Acta Orientalia Academiae Scientiarum Hungaricae } \\ & \text { (Budapest) }\end{aligned}$

AS =Bulletin of Academia Sinica $(=$ Chung-yang Yen-chiu-yutan Li-shih Y Yü-yen Yen-chiu-so Chi-k'an 中央研究院歴史語言 研究所集刊) (Peking, Shanghai, later Taipei)

BA = The Blue Annals (=Deb-ther snon-po) tr. by G. N. de Roerich.

$B E F E O=$ Bulletin de l'École Française d'Extrême-Orient (Hanoi, later Paris)

$B S O(A) S=$ Bulletin of the School of Oriental (and African) Studies (London)

Bulletin = Bulletin de la Classe des Sciences Historiques, Philologiques et Politiques de l'Académie Impériale des Sciences de Saint-Pétersbourg (St Petersburg)

$C A J=$ Central Asiatic Journal (The Hague/Wiesbaden)

$C G=$ Chūgoku Gogaku 中國語學 (Tokyo)

CGKR =Chūgoku Gogaku Kenkyūkai Ronshū 中國語學研究會諭集 (Tokyo)

CKRS =Chügoku Kankei Ronsetsu Shiryō ......Bungaku, Gogaku, Geijutsu 中國關係論說資料 .......文學，語學，蓺術（Tokyo： Hokushin Shoten)

CYYY = Chung-yüan Yin-yün 中原音韻 by Chou Te-ch'ing.

CTT =Ching-yu T'ien-chu Tzu-yüan 景祐天等字源 by Wei-ching.

EYT =Erdeni-yin Tobzi by Saran Sečen Qong Tayiji.

FJHC =Fu-jen Hsüeh-chih 輔仁學誌 (Peking)

FLT =Fo-tsu Li-tai T'ung-tsai 佛祖歷代通載 by Nien-ch'ang.

FSK $=F a$-shu-k'ao 法書考 by Sheng Hsi-ming.

$G K=$ Gengo Kenkyū 言語研究 (Tokyo) 


\begin{tabular}{|c|c|}
\hline$H C$ & by $\mathrm{W}$ : \\
\hline HCCS & $\begin{array}{l}=\text { Huang-chi Ching-shih T'ien-sheng Ti-yin T" } u \text { 皇極經世天 } \\
\text { 聲地音圓 by Shao Yung. }\end{array}$ \\
\hline$H D G G K$ & $\begin{aligned}= & \text { Hokkaidō Daigaku Gaikokugo Gaikokubungaku Kenkyū } \\
& \text { 北海道大學外國語外國文學研究 (Sapporo) }\end{aligned}$ \\
\hline$H J A S$ & $=$ Harvard Journal of Asiatic Studies (Cambridge, Mass.) \\
\hline HYHP & $\begin{array}{c}=\text { Hsin-ya Hsüeh-pao 新亞學報 (Hong Kong: New Asia } \\
\text { College 新亞書院, Chinese University of Hong Kong) }\end{array}$ \\
\hline HYS & $=H \sin Y \ddot{u} a n-s h i h$ 新元史 by K'o Shao-min. \\
\hline IAN & $=$ Izvestija Akademii Nauk SSSR (Moscow) \\
\hline$I B K$ & =Indogaku Bukkyōgaku Kenkyü 印度學佛敨舉研究 (Tokyo) \\
\hline$J A$ & $=$ Journal Asiatique (Paris) \\
\hline$J A O S$ & $\begin{aligned}= & \text { Journal of the American Oriental Society (Boston/New } \\
& \text { Haven } / \text { New York) }\end{aligned}$ \\
\hline$J A S B$ & $=$ Journal of the Asiatic Society of Bengal (Calcutta) \\
\hline JOS & $=$ Journal of Oriental Studies (Hong Kong) \\
\hline JRAS & $=$ Journal of the Royal Asiatic Society (London) \\
\hline JSFOu & $=$ Journal de la Société Finno-Ougrienne (Helsinki) \\
\hline$K S z$ & $\begin{aligned}= & \text { Keleti Szemle ( }=\text { Revue Orientale pour les Etudes Ouralo- } \\
& \text { Altaiques) (Budapest) }\end{aligned}$ \\
\hline$M A S B$ & $=$ Memoirs of the Asiatic Society of Bengal (Calcutta) \\
\hline MIO & $=$ Mitteilungen des Instituts für Orientforschung (Berlin) \\
\hline$M K J I$ & $\begin{aligned}= & \text { Móko Jiin } \text { 蒙古字頱, a facsimile edition of the Meng-ku } \\
& \text { Tzu-yün published by Kansai University. }\end{aligned}$ \\
\hline$M K T Y$ & $=$ Meng-ku Tzu-yün 蒙古字親 by Chu Tsung-wen. \\
\hline$M S$ & $=$ Monumenta Serica (Peking, later Nagoya and Los Angeles) \\
\hline MSOS & $\begin{aligned}= & \text { Mitteilungen des Seminars fur orientalische Sprache an } \\
& \text { der Friedrich-Wilhelm-Universität zu Berlin (Berlin) }\end{aligned}$ \\
\hline$N C G H$ & =Nihon Chūgoku Gakkaihō 日本中國學會報（Tokyo） \\
\hline$N D B K R$ & $\begin{aligned}= & \text { Nagoya Daigaku Bungakubu Kenkyū Ronshū 名古屋大學 } \\
& \text { 交學部研究論集 (Nagoya) }\end{aligned}$ \\
\hline NSTH & $\begin{aligned}= & \text { Nü-shih Ta-hsüeh Hsüeh-shu Chi-k'an 女師大學學術季刊 } \\
& \text { (Peking) }\end{aligned}$ \\
\hline
\end{tabular}




\begin{tabular}{|c|c|}
\hline OJDJK & $\begin{aligned}= & \text { Ochanomizu Joshi Daigaku Jinbun Kagaku Kiyō 摔の } \\
& \text { 水女子大學人文科學紀要 (Tokyo) }\end{aligned}$ \\
\hline$O D K N$ & 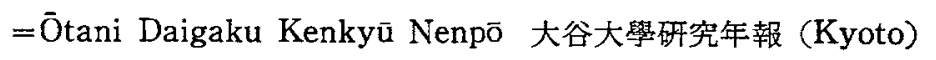 \\
\hline$P C H$ & $=$ Po-chia-hsing 百家姓. \\
\hline PCTH & $\begin{aligned}= & \text { Pei-ching Ta-hsüeh Kuo-hsüeh Chi-k'an 北京大學國學季刊 } \\
& \text { (Peking) }\end{aligned}$ \\
\hline PPTSK & $=$ Pei-p'ing T'u-shu-kuan Kuan-k'an 北平圖書館館刊 (Peking) \\
\hline$P S P T$ & $\begin{aligned}= & P a \cdot s s u-p a-t z u \text { yï Yüan-tai Han-yii 八思巴字與元代漢語 } \\
& \text { (資料魚編) edited by Lo Ch'ang-p'ei and Ts'ai Mei-piao. }\end{aligned}$ \\
\hline$R A$ & $\begin{array}{l}=\text { The Red Annals }(=H u-l a n \text { deb-ther/Deb-ther dmar-po })(= \\
\text { The Lineage of the Sa skya pa. A Chapter of the Red } \\
\text { Annals. }) \text { tr. by S. Inaba. }\end{array}$ \\
\hline RO & $=$ Rocznik Orjentalistyczny (Lwów) \\
\hline SO & $=$ Studia Orientalia (Helsinki) \\
\hline$S S H Y$ & $=$ Shu-shih Hui-yao 書史會要 by T'ao Tsung-i. \\
\hline$S Z$ & =Shigaku Zasshi 史學雜誌 (Tokyo) \\
\hline Taishō & $\begin{array}{c}=\text { Taishō Shinsh } \bar{u} \text { Daizōkyo 大正新修大藏經 (The Tripițaka } \\
\text { in Chinese) edited by J. Takakusu and K. Watanabe. }\end{array}$ \\
\hline$T H G$ & =Tōhōgaku 東方學 (Tokyo) \\
\hline Tōhoku & $\begin{array}{l}=\text { Chibetto Senjutsu Butten Mokuroku 西藏撰述佛典目録 }(=\mathrm{A} \\
\text { Catologue of the Tōhoku University Collection of Tib- } \\
\text { etan Works on Buddhism) (Sendai, 1953) }\end{array}$ \\
\hline$T P$ & $=$ T'oung Pao (Leiden) \\
\hline$T P S$ & $=$ Tibetan Painted Scrolls by G. Tucci. \\
\hline TSNP & $=T i$-shih Nieh-p'an 帝師涅槃 by Te-hui ch'an-shih. \\
\hline TSTP & $=T i$-shih Tien-pei 帝師澱碑 by Shih-yüan tsung-chu. \\
\hline TVOIRAO & $\begin{aligned}= & \text { Trudy Vostočnago Otdelenija Imperatorskago Russkago } \\
& \text { Arxeologičeskago Obščestva (St Petersburg) }\end{aligned}$ \\
\hline TYGH & $=$ Tōyō Gakuhō 東洋學報 (Tōkyō) \\
\hline$V D L$ & $=$ The Fifth Dalai Lama's Chronicle. \\
\hline$W W(T K)$ & $=$ Wen-wu (Ts'an-k'ao Tzu-liao) 交物(參考資料) (Peking) \\
\hline$W Z K M$ & $\begin{aligned}= & \text { Wiener Zeitschrift für die Kunde des Morgenlandes } \\
& \text { (Vienna) }\end{aligned}$ \\
\hline
\end{tabular}


YCHP = Yen-ching Hsüeh-pao 燕京學報 (Peking)

YS $=$ Yüan-shih 元史 by Sung Lien and others.

$Y S L P \quad=$ Yüan-shih Lei-pien 元史類編 by Shao Yüan-p'ing.

$Z D M G \quad=$ Zeitschrift der deutschen morgenländischen Gesellschaft

(Leipzig, later Wiesbaden)

ZIAN =Zapiski Amperotorskoj Akademii Nauk' (St Petersburg)

ZKM =Zeitschrift für die Kunde des Morgenlandes (Göttingen)

ŽMVD = Žurnal' Ministerstva Vnuternnix' del' (St Petersburg)

ZSOIRGO =Zapiski Sibirskago otdelenija Imperatorskago Russkago

Geografičeskago obščestva (St Petersburg)

ZSPANO =Zapiski Sankt'-Peterburgskago Arxeologičeskago i Numizmatičeskago Obščestva (St Petersburg)

ZY=Zhongguo Yuwen(=Chung-kuo Yü-wen)中國語文(Peking)

General (mainly used in tables)

abbr. = abbreviation(s), abbreviated.

AC $\quad=$ Ancient Chinese.

Bibl. =Bibliography in this paper.

c =ch'ï-sheng 去聲 (=falling-tone).

$\mathrm{Ch}(\mathrm{in}) . \quad=$ Chinese.

$\mathrm{E}$ (group) =cerebral group. See Table 1 .

$\mathrm{F}$ (group) =supradental and affricated alveolo-palatal group. See Table 1.

fasc. $\quad$ fasicle(s).

fol (s). $\quad=$ folio $(s)$.

$\mathrm{G}$ (group) = sibilant group. See Table 1 .

h.k. =ho-k'ou 合口 (=rounded-mouth sounds).

I./init. =initial consonant(s).

j =ju-sheng 入聲 (=entering-tone).

k.k. $\quad=k^{\prime} a i-k^{\prime}$ ou 開口 (=open-mouth sounds).

MC $\quad=$ Middle Chinese.

M. $/$ med. =medial(s).

Mong. = Mongolian.

N./nuc. =nucleus(-clei). 


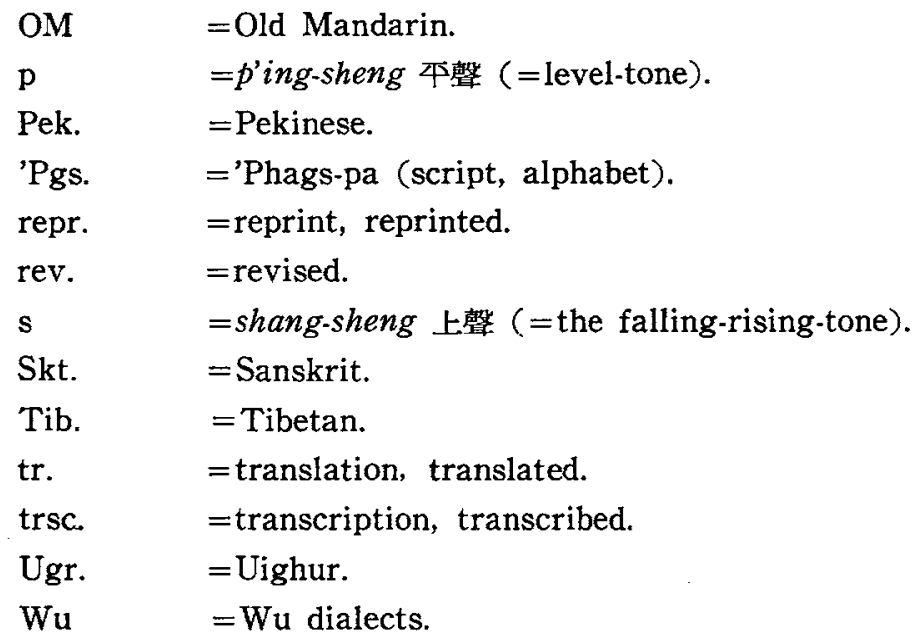




\section{INTRODUCTION}

THE 'Phags-pa script was invented by Bla-ma 'Phags-pa and was officially used by the Mongol Empire. The original plan of this script, mentioned in the Imperial decree that promulgated it in 1269, was to transcribe Mongolian and other neighbouring languages. As the time that the 'Phags-pa script was in official use was limited to the Mongol Empire, 'Phags-pa material at our disposal is extremely limited, and the only available material in the script is written in Mongolian, Chinese, and Tibetan.

The Mongolian documents in the 'Phags-pa script are mostly inscriptions, and in conjunction with documents in the Uighur script, which was adopted by the Mongols after 1204, ${ }^{1}$ they are very important material for the study of the Mongolian language in the thirteenth and fourteenth centuries.

The period of the Yüan dynasty (the Mongol Empire) can be regarded as a new stage in the history of the Chinese language, which had undergone great phonological changes since the late T'ang dynasty, and the phonetic system of Chinese in the Yüan dynasty should be strictly distinguished from Ancient Chinese. The 'Phags-pa documents are most important materials for the study of Chinese in the Yuian dynasty because they represent each Chinese character with a phonetic symbol. These documents show the features of Middle Chinese phonology more accurately than the rhyme dictionaries such as the Chung-yüan Yin-yün 中原吾韻 (abbr. CYYY)(1324). During the T'ang dynasty, the Chinese language was transcribed by the Uighur and Tibetan scripts, ${ }^{2}$ but the 'Phags-pa

1 See J.P. Abel-Rémusat, 'Tha-tha-toung-'a, Ministre ouigour', Nouveaux mé'anges asiatiques, II (Paris, 1829), pp. 61-3 ; B. Laufer, 'Skizze der mongolischen Literatur', $K S z$, VIII (1907), p. 183.

2 See B.Csongor, 'Chinese in the Uighur script of the T'ang-period', $A O H$, II (1952), pp. 73-121 ; T. Haneda, 'Kan-Ban taion Senjimon no dankan', TYGH, XIII, 3 (1923), pp. 390-410; F.W. Thomas and G.L. M. Clauson, 'A Chinese Buddhist text in Tibetan writing', JRAS, 1926, pp. 508-26, and 'A second Chinese Buddhist text in Tibetan characters', JRAS, 1927, pp. 281-306, 858-60; F. W. Thomas, S. Miyamoto, and G. L. M. Clauson, 'A Chinese Mahäyāna catechism in Tibetan and Chinese characters', JRAS, 1929, pp. 37-76 ; Lo Ch'ang-p'ei, T'ang Wu-tai Hsi-pei Fang-yin (Shanghai, 1933), 223 pp.; W.Simon, 'A note on Chinese texts in Tibetan trans- 
transcription of Chinese in the Yüan dynasty provides much more systematic material.

Tibetan materials, mostly seals, in the 'Phags-pa script were produced after the fall of the Yüan dynasty, much later than the Mongolian and Chinese materials. From the Tibetan viewpoint, the 'Phags-pa script was very probably a variant of Tibetan script, or simply seal-characters. As I will discuss later, some Tibetologists regard the 'Phags-pa script as Tibetan seal-characters or as Tibeto-Mongol characters, and it is difficult to decide whether the Tibetans, in using 'Phags-pa script for seals, had any great knowledge of the script. Even if the Tibetans had invented a seal-script based on the Tibetan dbu-can (printing characters), this would naturally resemble the 'Phags-pa script, which was also derived from the $d b u$-can. In this paper, however, Tibetan seal-characters will be regarded as a form of the 'Phags-pa script.

A brief history of 'Phags-pa studies is as follows.

The first systematic reference to 'Phags-pa studies was made by $H$. C. von der Gabelentz in $1839,{ }^{3}$ although a few scholars had touched upon it earlier. ${ }^{4}$ Von der Gabelentz dealt with the epigraph of The Edict of Buyantu Qan 1314, which he reproduced from the Shih-mo Chüan-hua 石墨䥰華 (1618) by Chao Han. ${ }^{5}$ In that text the 'Phags-pa inscription is written in the Chinese way, by vertical columns from right to left. Von der Gabelentz first transcribed it in this way, then rearranged it correctly in the Mongolian way, in vertical columns from left to right. He also gave a romanisation of the parallel Chinese inscription, with a German translation and some commentaries. As the reproduction of the

cription', BSOAS, XXI (1958),'pp. 334-43 ; B. Csongor, 'Some Chinese texts in Tibetan script from Tun-huang', $A O H, X(1960)$, pp. 97-140.

3 'Versuch über eine alte mongolische Inschrift', $Z K M$, II, 1 (1839), pp. 1-21+3 tables,

4 For example, P.S. Pallas, Sammlungen historischer Nachrichten über die mongolischen Völkerschaften, vol. II, p. 358, plate 22, and Catalogue des manuscrits chinois et mandchoux de la Bibliothèque royale de Berlin; J. Klaproth, Abhandlung über die Sprache und Schrift der Uiguren; J. P. Abel-Rémusat, Recherches sur les langues tartares ..., I, pp. 197-214, and 'Tha-tha-toung-'o, ...', p. 63.

5 Chih-pu-tsu-chai Ts'ung-shu edition ser. 3, vol. 6, pp.11b-14b, or Ts'ung-shu Chi$c h$ 'eng edition (based on the above) (No. 1607), pp. 77-82. 
'Phags-pa inscription in the Shih-mo Chüan-hua was not sufficiently clear, von der Gabelentz could not reconstruct the correct phonetic value of some letters. For example, he did not make any distinction between $g$, $q$ and - (intervocalic sign) but transcribed them all as $g .{ }^{6}$

In 1857 a Mongolian coin with the 'Phags-pa script was discovered by E. Netscher in Surabaya, in Java, and it was described and discussed by G. Pauthier. ${ }^{7}$ In 1862 Pauthier described a Chinese inscription in the 'Phags-pa script. ${ }^{8}$ His approach to 'Phags-pa orthography in Chinese documents was first to translate into French a biography of Bla-ma 'Phags-pa from the Yüan-shih 元史 and another passage concerning 'Phagspa script in the Shu-shih Hui-yao 書史會要 (abbr. SSHY). He then demonstrated the phonetic value of each letter in comparison with the Tibetan, Sanskrit, and Mongolian alphabets. His comment on the disappearance of the final consonants of the entering-tone is very likely the first reference to Middle Chinese phonology by a Western scholar. ${ }^{9}$

In 1871 six parallel inscriptions on the Wall of Chü-yung-kuan 居庸關 were described by A. Wylie. ${ }^{10}$ These inscriptions were of the [Sarvadurgati-parišsodhani-juṣnīșa-vijaya-nāma-dhärañi (cf. Taishō, Nos.967-71) on the east wall, and the Samanta-mukha-praveśa-raśmi-vimaloṣnișa-prabhāsasarva-tathägata-hrdaya-samaya-vilokita-nāma-dhärañī (cf.Taishō, No. 1025)on the west wall, and were written in Sanskrit (Lañtsha), Tibetan, Mongolian ('Phags-pa), Uighur, Hsi-hsia and Chinese. ${ }^{11}$ Wylie translated the Sanskrit inscription on the east wall and reproduced the original texts in the six scripts. In 1894-5 reports appeared after the lesser Chinese,

- For example, kiegen (read·ihe•en), erkegud (read èk'e-ud), iruger (read hiru-er), etc. But he corrected this point in his 'Nachtrag zur Erklärung der altmongolischen Inschrift', $Z K M$, III (1840), pp. 22-57.

7 'Rapport sur deux médailles en cuivre jaune trouvées à Sourabaya, ..., $J A, \mathrm{~V}$, 15 (1860), pp. 321-37+3 illustr. Two coins introduced in this article have Arabic and 'Phags-pa inscriptions. The 'Phags-pa inscription was deciphered as Ta-Yüan $t^{t}$ ung-pao 大元通寶 by Pauthier.

8 'De 1'alphabet de Pa'-sse-pa,...', JA, V, 19 (1862), pp. 5-47.

9 Ibid., p. 39.

10 'On an ancient Buddhist inscription at Keu-yung kwan, in North China', JRAS, n. s. V, 1 (1870), pp. 14-44+restoration of the Keu-yung-kwan Inscription.

11 Wylie (ibid.) gives a full account of 'Phags-pa studies until his time. He also (p. 26, n. 3) gives a specimen of 'Phags-pa script which he reproduced from a pillar 
Tibetan, Uighur, and Mongolian inscriptions of both walls had been de-

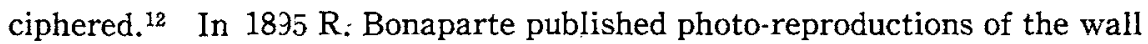
inscriptions of Chï-yung-kuan and some other 'Phags-pa documents such as The Edict of Buyantu Qan 1314, which von der Gabelentz and Wylie had already reproduced from Chinese sources. ${ }^{13}$ The publication of the Chüyung-kuan inscriptions was an epoch-making event in oriental palaeographical studies. Until then, for example, the Hsi-hsia script had been completely unknown. ${ }^{14}$ G. Devéria, who provided many reproductions of Chï-yung-kuan inscriptions to Bonaparte, also contributed to the decipherment of some 'Phags-pa inscriptions. ${ }^{15}$

Besides inscriptions of epigraphs in the 'Phags-pa script, some silver tablets ( $\left.p^{\prime} a i-t z u\right)$ had been found in Siberia, inscribed in Mongolian in the 'Phags-pa script. ${ }^{16} \quad$ D. Banzarov successfully identified the Minusinsk $p^{\prime} a i-t z u$ inscription as the 'Phags-pa script, ${ }^{17}$ although it had earlier been

of Yung-ho-kung, Peking. According to Wylie, Pallas (op. cit., vol, II, plate 22) also gives a similar specimen to his own. The 'Phags-pa alphabet in this speci. men is arranged in the Tibetan alphabetical order, i.e., om, $a, \vec{a}, \ldots k, k h, \ldots$, and it is most interesting that this specimen lacks voiced consonants, i. e. the $g, d, b$, ...series. But some of the letters are indecipherable either because the reproduction was inadequate or because the original was illegible. As regards other in scriptions, he mistakenly identified the Hsi-hsia script as Neuchih (Jurchen) script. For further details, see E. Teramoto, 'Kyoyōkan no hekibun oyobi sono chōkoku bijutsu ni tsuite', $S Z$, XX (1910), pp. 351-64,609-17, 1514-16 ; J. Murata (ed.), Kyoyōkan, 2 vols.

12 'Note préliminaire sur l'inscription de Kiu-yong koan': E. Chavannes, 'Première partie. Les inscriptions chinoises et mongoles', JA, IX, 4 (1894), pp. 354-68 ; S. Lévi, 'Deuxième partie. Les inscriptions tibétaines', ibid., pp. 369-73 ; W. Radloff, 'Troisième partie. Les inscriptions ouigoures', ibid., pp.546-50; G. Huth, 'Quatrième partie. Les inscriptions mongoles', ibid., IX, 5 (1895), pp. 351-60.

13 Documents de l'époque mongo'e des XIII et $X I V^{\mathrm{e}}$ siècles..., II $+5 \mathrm{pp}+15$ plates.

14 After Wylie identified the Hsi-hsia script as the Jurchen (op. cit. , pp. 36-44), Devéria corrected Wylie's mistaken assumption in his ' $L$ 'écriture du royaume de Sihia ou Tangout', Mémoirs présentes par divers savants à l'Académiedes Inscrip. tions et Belles-Lettres de l'Institut de France, sér, I, tome XI (1901), pp. 147-75. As to the history of deciphering the Hsi-hsia script, see T. Nishida, Seikago no kenkyū, vol. I (Tokyo: Zauhō Kankōkai, 1964), pp. 1-14.

15 'Notes d'épigraphie mongole-chinoise', JA, IX, 7, 8 (1896), pp. 94-128, 395-443.

16 In 1846 a $p$ ' $a i-t z u$ was discovered in Minusinsk and introduced for the first time in H. Yule (tr. and ed.), The Book of Ser Marco Polo, I, Book VII, plate facing p. 352. 17 'Über zwei mittelasiatische Alphabete...', Bulletin, V, 4 (1848), Sp. 49-57 ; 'Erklä- 
believed to be the Hsi-hsia script. ${ }^{18}$

The first scholar to study the 'Phags-pa script from the Tibetan sources was B.H. Hodgson (1828). ${ }^{19}$ He provided a 'Phags-pa specimen among his plates, to which an explanation written in dbu-med (Tibetan cursive script) letters is added. ${ }^{20}$ S.C. Das also gives a full account of various ornamental characters in which three 'Phags-pa specimens are included (1888). ${ }^{21}$ However, Das did not identify these specimens as the 'Phags-pa script but regarded them as Khon-sen, Sin-tu brjod-pa, and Yugur (Uighur) characters. ${ }^{22}$ Apparently he had no knowledge of the Uighur script, which continued to be used by the Mongols even after the invention of the 'Phags-pa script.

In 1905 two seals of the Dalai Lama were reproduced by L. A. Waddell. $^{23}$ One of these is a Lañtsha monogram ${ }^{24}$ and the other is in the

rung einer mongolischen Inschrift ...', ibid., V,9 (1848), Sp. 129-39; 'Pajze, ili metalličeskija došččki s' povelenijami' mongol'skix xanov', ZSPANO, II, 1 (1850), pp. $72-97$.

18 For example, V. Grigor'eev, 'Ob'jasnanie drevnej mongol'skoj nadpisi, najdennoj v' Sibiri', 'ZMVD, XVI (1846), pp. 126-49; Otvet' akademiku Šmidtu na zamečanija ego o mongol'skoj nadpisi vremen' Mönghe-xana, najdennoj v' Sibiri, Otečestvennyja Zapiski (St Petersburg, 1846), pp. 114-20. Grigor'eev suggested that the invention of the 'Phags-pa script was not made during Qubilai's reign but in the eleventh century by Li Yüan-hao 李元导 of Tangut. Since on this $p^{\prime} a i$-tzu there are the words 'Möngke Qan' Grigor'eev maintained that this script must have been used before Qubilai's reign. I.J. Schmidt opposed Grigor'eev's view and rendered the word 'Möngke' as an adjective 'eternal' ('Über eine mongolische Quadratinschrift aus der Regierungszeit der mongolischen Dynastie Jüan in China', Bulletin, IV, 9 (1848), Sp. 129-41). But Banzarov advanced on these interpretations by Schmidt and Avvakum ('O nadpisi, naxodjaščejsja na skale u Mangutskoj peščery', ZSOIRGO, II (1865), pp. 87-8) and concluded that the words 'Möngke Qan' on this p'ai-zu were a copy in 'Phags-pa of an original in Uighur script written in Möngke Qan's reign.

19 'Notices of the Languages, Literature, and Religion of the Bauddhas of Nepal and Bhot', Asiatic Researches, XVI, (1828), Article No. XII, pp. 409-49, esp. see the third plate after p. 420.

20 This explanation can be read 'di-yan hor-yig rigs gcig lun ("This is also a kind of authorized Hor-yig'). Hor-yig means the letters (yig) used in Mongolia (hor).

21 'The sacred and ornamental characters of Tibet', JASB, LVII (1888), pp. 41-8 +9 plates.

22 Ibid., pp. 45-6, plates V(b) (Khoǹ-sen), (e) (Śin-tu brjod-pa), plate VII, No. 1 (Uighur). $\quad{ }_{23}$ Lhasa and its Mysteries, p. 448.

24 Cf. Hodgson, op. cit., the fifth plate after p. 420; Das, op.cit., p.47, plate V(d). 
'Phags.pa script. S.W. Bushell gave a reading of the 'Phags-pa seal, ${ }^{25}$ of which A.H. Francke and Waddell both gave different interpretations. ${ }^{26}$ Francke also published some other Tibetan seals ${ }^{27}$ and E.H. Walsh gave many further examples. ${ }^{29}$ In these Tibetan pieces, some letters are slightly different in shape from those in Mongolian and Chinese materials. ${ }^{29}$

This period, from the second half of the nineteenth century to the early part of the twentieth, was thus the discovery period for materials in the 'Phags-pa script from Mongolian, Chinese, and Tibetan sources. However, while the two former sources have been dealt with by scholars of Mongolian and Chinese in collaboration, the Tibetan sources have always been treated only by students of Tibetan.

25 Bushell reads: 'Talai bLamai...Thamka rgyalva [ta-la'i bla-ma'i...tham-ka rgyal$b a$ ] ('The royal seal of the Dalai Lama') (review of Waddell, op. cit., JRAS, 1906, p. 478). Bushell states: 'The inscription seems to be rather an archaic form of the Tibetan script, and is to be read in vertical columns, passing from left to right, like the Bashpa script of the thirteenth century'. W.H. Walsh ('The coinage of Tibet', $M A S B$, II, 2(1907), p. 17) also gives a short comment on this seal, but apparently he did not consult Bushell's review. Walsh states: 'This character of the Dalai Lama's seal is called in Tibetan Shintu-Jod-pa [Śin-tu brjod-pa] or "perfectly finished" and resembles the Uighur characters, known in Tibet as Gyaser Yige [rgya-ser yi-ge] or "Great golden letters", and is found in almost all old seals of Tibet.'

26 Francke ('Note of the Dalai Lama's seal and the Tibeto-Mongolian characters', JRAS, 1910, p. 1206) reads: 'talai blamai ru thamka rgyal [ta-la'i bla-ma'i ru tham-ka rgyal] ('Standard seal of the Dalai Lama, bene!')'. But Waddell ('Seal of the Dalai Lama', JRAS, 1911, pp. 204-6) opposed this reading and gave another version as 'Om ta-lai bla-mai rtsa t'amka rgyal-va [Om ta-la'i bla-ma'i rtsa-tham$k a$ rgyal.ba] ('Om! The original seal of the Talai Lama, the Jina')'. Francke ('The Dalai Lama's seal', JRAS, 1911, pp. 523-33), however, did not accept Waddell's criticism.

27 'Ein Siegel in tibeto-mongolischer Schrift von Bhutan', ZDMG, LXIV (1910), pp. 553-4; 'Another version of the Dalai Lama's seal', JRAS, 1912, pp. 746-8.

28 'Seal of Dalai Lama', JRAS, 1911, pp. 206-7; 'Examples of Tibetan seals', JRAS, 1915, pp. 1-15; 'Examples of Tibetan seals: Supplementary note', ibid,, pp. $465-70$.

29 For example, the letters which are equivalent to the Tibetan $p h, t s, t s h, d z$, etc. Cf. Francke, 'Note on the Dalai Lama's seal...', pp. 1211-12 (comparative table of Hor-yig, Kon-sen, and Sin-tu brjod-pa). 
At almost the same time another great problem arose, concerning the inventor of this script. According to the Yüan-shih (1370), Bla-ma 'Phags-pa invented a new Mongolian script and offered it to the throne in 1269, and this statement has been followed by many Chinese sources. However, the famous Tibetan chronicles, Hu-lan deb-ther (The Red Annals) (1346) and the Deb-ther snon-po (The Blue Annals) (1476-8), make no mention of this. ${ }^{30}$ The Sñin-tshil (Mong. Jirüken-ï Tolta), which is said to have been written by Chos-kyi 'Od-zer, a monk of the Yüan dynasty, and which was translated into Mongolian between 1723 and $1735,{ }^{31}$ states that while Sa-skya paṇdita was staying in Liang-chou (1247-51), intending to confer the benefit of a script upon the Mongolians, he fell one night into a fit of abstraction. In the early morning a woman appeared with a notched-stick for tanning leather. Sa-skya pandita responded to this apparition by creating a Mongolian script in the shape of the notched-stick, embodying masculine, feminine and neuter genders as follows :

$\begin{array}{lll}\text { a } & \text { e } & \mathrm{i} \\ \text { na } & \text { ne } & \text { ni } \\ \text { ba } & \text { be } & \text { bi } \\ \text { qa } & \text { ke } & \text { ki } \\ \text { ra } & \text { ge } & \text { gi } \\ \text { ma } & \text { me } & \text { mi } \\ \text { la } & \text { le } & \text { li } \\ \text { ra } & \text { re } & \text { ri } \\ \text { sa } & \text { se } & \text { si } \\ \text { da } & \text { de } & \text { di } \\ \text { ta } & \text { te } & \text { ti } \\ \text { ya } & \text { ye } & \text { yi } \\ \text { ca } & \text { ce } & \text { ci } \\ \text { ja } & \text { ye } & \text { ji } \\ \text { va } & \text { ve } & \ldots\end{array}$

30 See Chapter I.

31 See H. Okada, 'Mōko shiryō ni mieru shoki no Mō-Zō kankei', THG, 23 (1962), p. 105. 
But, as the time was not yet ripe, Mongolian translations of Buddhist texts in this script did not appear. ${ }^{32}$

The Bolor Erike (1774-5) copies this passage of the Jirïken-ü Tolta, ${ }^{33}$ the Hor-chos-byun by Jigs-med rig-pa'i rdo-rje (1819), ${ }^{34}$ also copies this passage and adds the fact that Chos-kyi 'Od-zer revised the new Mongolian script invented by Sa-skya pandita. ${ }^{35}$ The accounts in the above sources have been adopted by Klaproth, de Lacouperie, Koeppen, Francke, Teramoto, and Krause, ${ }^{36}$ although their interpretations often differ. The Mongolian script referred to by these sources is generally supposed to be the Uighur script which the Mongols began to use no later than 1230. ${ }^{37}$ Probably the Mongolian sources mentioned above ascribe the invention of the Mongolian script to Sa-skya pandita because of their respect for him as the person who first introduced Buddhism to Mongolia. The reason these sources make no mention of the 'Phags-pa script was

32 See I.J. Schmidt, Geschichte der Ost-Mongolen und ihres Fürstenhauses, pp. 392-4; Okada, ibid., pp. 105-7.

33 Bolor Erike, Mongolian Chronicle (=Scripta Mongolica, III) (Cambridge, Mass., 1959), Part I, pp. 171-2; Part IV, pp. 121-2; Okada, ibid., p. 103.

34 The name of the author of the Hor-chos-byun was mistakenly believed to be Jigs-med nam-mka' until G. N. de Roerich ('The author of the Hor-chos- $h$ byun', JRAS, 1946, pp. 192-6) assigned it to Jigs-med rig-pa'i rdo-rje.

35 See G. Huth, Geschichte des Buddhismus in der Mongolei..., pp. 133-4, 162-3.

${ }^{36}$ J. Klaproth, 'De l'écriture ouigoure', Archives Palégraphiques, I (1872), p. 87; $\mathrm{T}$. de Lacouperie, Beginnings of Writing in Central and Eastern Asia,..., pp. 88-90; C.F. Koeppen, Die lamaische Hierarchie und Kirche, pp. 96-100; Francke, 'Note on the Dalai Lama's seal...', p. 1208; E. Teramoto, 'Pakupa Rama no shin Mōko moji', Bukkyō Shigaku, I, 11(1912), pp. 917-34, ibid., II, 2 (1912), pp. 108 27, and Chibettogo Bunpo, pp. 6-7; F.E.A. Krause, $J u-T a o-F o, \ldots$, p. 585, nn.291-2 (cf. P. Pelliot's review, TP, XXIII (1924), p. 62).

37 The earliest Mongolian document in the Uighur script is the so-called 'Stone of Činggis Qan' which was found in the Nerchinsk area near the River Onon. See Schmidt, 'Bericht über eine Inschrift aus der ältesten Zeit der Mongolen-Herrschaft', Mémoires de l'Académie des Sciences de St.Pétersbourg, sér. VI, vol. II (1834), pp. 243-56; von der Gabelentz, op. cit., pp. 18-21 ('Nachschrift'); Banzarov, 'Ob'jasnenie mongol'skoj nadpisi na namjatnike kniazja Isunke plemjannika Čingis; Xana', Sbornik' Černaja V'ra (ed. by G.N. de Potanin)(St Petersburg, 1891), pp.88105; Laufer, op. cit., pp. 191-2; S. Murayama, 'Jingisu-Kan sekibun no Kaidoku', Tóyoggo Kenkyua, 4 (1948), pp. 59-95. Schmidt puts the date of this stone between 1219 and 1220, but Banzarov places it between 1224 and 1230. The letter to 
probably because after the fall of the Mongol Empire it was no longer officially used and therefore Tibetan and Mongolian sources ignored it.

P. Pelliot demonstrates that Chos-kyi 'Od-zer corresponds to Shuossu-chi-yüeh-chi-erh 搠思吉月郎兒 in the Yüan-tai Hua-so-chi 元代畫塑記 or Shuo-ssu-chi-o-chieh-erh-pa-ha-shih 猢思吉斡節兒八哈失 in the Yüan-shih (fasc. 99), but these Chinese sources do not mention his revision of the Mongolian script. Pelliot instances a story that Tatatunga, a Naiman minister, taught the Uighur script to Cinggis Qan's princes and that the first Mongolian chronicle Monrol-un ni'uča tobči'an (The Secret History of the Mongols) was written in the Uighur script in 1240,38 and he then notes that:

...Mais par là les deux lamas [Sa-skya paṇita and Chos-kyi 'Od-zer], formés à la grammaire tibétaine inspirée elle-même de la grammaire hindoue, ont fait oeuvre de phonéticiens exerçant leurs facultés d'analyse sur un système d'écriture qui existait déjà. Ils n'ont rien inventé, et si leurs noms doivent être retenus peut-être dans l'histoire de la grammaire mongole, l'écriture mongole elle-même, à mon sens, ne leur doit rien. ${ }^{39}$

Points made by Pelliot are now regarded as self-evident, but they were not clearly grasped until Pelliot's deductions. Before Pelliot, B. Laufer had already concluded that Bla-ma 'Phags-pa invented the 'Phags-pa script but he also believed that the revision of the Uighur script was made by Chos-kyi 'Od-zer between 1307 and $1311 .^{40} \mathrm{M}$.Ishida also contributed

Philippe le Bel'(see Bonaparte, op. cit., plate XIV, No. 1) from Činggis Qan can be also regarded as one of the earliest Mongolian documents in the Uigur script.

38 'Les systèmes d'écriture en usage chez les anciens mongols', $A M$, II (1925), pp. 284-9. The most recent researches suggest a much earlier date for the writing of the Secret History of the Mongols than Pelliot ascribes. For example, I. de Rachewiltz ('Some remarks on the dating of the Secret History of the Mongols', MS, XXIV (1965), pp. 185-206) proposes it as exactly one year after the death of Cinggis Qan, in the seventh month of the year of the Rat (1228). Also see G. Doerfer, 'Zur Datierung der Geheimen Geschichte der Mongolen', ZDMG, 113 (1963), pp. 87-111; P. Ratchnevsky, 'Šigi-qutuqu, ein mongolischer Gefolgsmann im 12.-13. Jahrhundert', CAJ, X (1965), pp. 87-120.

39 Pelliot, op. cit., p. 289.

40 Laufer, op. cit., pp. 183-6. 
to this problem from the same viewpoint as Pelliot. ${ }^{41}$ G.N. de Roerich, following V. Vladimircovi2 and Pelliot on Chos-kyi 'Od-zer, suggested that he lived somewhat earlier ( -1292 ?) than the date given in the Yüan-shih (-1321 ?).43

Until this time, most scholars of 'Phags-pa studies had dealt with Mongolian and Chinese epigraphs and Tibetan seals. Very rarely, discoveries of 'Phags-pa specimens in block-prints or printings were also noted. In the Chinese block-print Rgya-dkar-nag rgya-ser ka-smi-ra bal bod hor-gyi yi-ge dair dpe-ris mam-grañs man-ba, there are three 'Phags-pa specimens, which were described by $\mathrm{O}$. Böhtlingk ${ }^{44}$ and $\mathrm{A}$. Schiefner. ${ }^{45}$ As their descriptions were too cursory, it is regrettable that Das, who also dealt with this text, did not identify them as 'Phags-pa script. ${ }^{46}$

The so-called Mannerheim fragment, discovered by the C.G. Mannerheim expedition (1906-3) to Eastern Turkestan, was first described by G.J. Ramstedt. ${ }^{47}$ Later P. Aalto identified this as part of a Mongolian transcription of the Subhassitaratnanidhi. ${ }^{48}$ These discoveries in block-print or printing stimulated the new idea that the 'Phags-pa script had been

41 'Mōko moji no kigen to enkaku', Töa, III, 12 (1930), pp. 84-92.

42 Sravnitel'naja Grammatika Mongol'skogo Pis'mennogo jazyka i Xalxaskogo Nareijia. Vvedenie i fonetika (Leningrad, 1929), pp. 23-36.

43 'Mun-mkhyen Chos-kyi hod-zer and the origin of the Mongolian alphabet', $J A S B, \mathrm{XI}, 1$ (1945), pp. 52-8.

44 'Ueber einige Sanskrit-Werke in der Bibliothek des Asiatischen Departements', Bulletin, II, 22 (1845), Sp. 342-4 (catalogue Nos. 574,590).

45 'Nachträge zu den von O. Böhtlingk und I.J. Schmidt verfassten Verzeichnissen der auf Indien und Tibet bezüglichen Handschriften und Holzdrucke im Asiatischen Museum der Kais. Akademie der Wissenschaften', Bulletin, V, 10 (1848), Sp. 147 (No. 125aaa), n. 1.

46 The nine specimens in Das's plate $\mathrm{V}$ are exactly the same as those in this text, fols. 13b-14b. As regards this text, see A. Yuyama, Indic Manuscripts and Chinese Blockprints (non-Chinese Texts) of the Oriental Collection of the Australian National University Library, Canberra, pp. 84-100; Nakano, 'The Rgya-dkar-nag ... and some remarks on the 'Phags-pa script', Indo-Asian Studies, III (1971), pp. 1-16.

47 'Ein Fragment mongolischer Quadratschrift', JSFOu, XXVII, 3 (1911), pp. 1-4.

48 'Altaistica I. The Mannerheim fragment of Mongolian "Quadratic" script', $S O$, XXII, 7 (1952), pp. 1-9. In 1925 T.F. Carter provided a fragment similar to the Mannerheim fragment in his The Invention of Printing in China and its Spread 
used not only in epigraphs and seals but also in printing.

Although many scholars such as Maspero, Karlgren, and Simon had steadily advanced Archaic and Ancient Chinese studies, ${ }^{49}$ studies of Middle Chinese had been ignored until A. Dragunov and H. Oshibuchi produced parallel contributions in $1930 .^{50}$ Dragunov referred to about 700 Chinese characters and their 'Phags-pa equivalents which had been found in epigraphs, and discussed some peculiarities of Middle Chinese phonology. Oshibuchi also chose a matching number of Chinese characters in the CYYY to those in 'Phags-pa inscriptions, and assigned their phonetic value. The works of Dragunov and Oshibuchi provided a form of material on Middle Chinese sounds and a realistic methodology for dealing with Chinese documents in the 'Phags-pa script. At this stage M. Lewicki systematised almost all the Mongolian 'Phags-pa inscriptions ever found, ${ }^{51}$ and $\mathrm{W}$. Kotwicz also clarified some problems regarding Mongolian transcription of Buddhist texts and some initial formulae in Mongolian inscriptions, especially edicts. ${ }^{52}$

The new stage of 'Phags-pa studies begins with two significant contributions by N.N. Poppe and S. Hattori.

Westward, plate facing p. 120 , and Aalto again identified this fragment in his 'A second fragment of the Subhāșitaratnanidhi in Mongolian quadratic script', JSFOu, LVIII, 5(1954), pp. 1-6 and 'Frangmente des mongolischen Subhāṣitaratnanidhi in Quadratschrift', MIO, III (1955), pp. 279-90. As to Carter's book, Pelliot gives a full account of critical and additional study (Les débuts de l'imprimerie en Chine)(=Oeuvres posthumes de Paul Pelliot, IV) (Paris: Librairie d'Amérique et d'Orient, 1953), viii +120 pp. + 'Appendice' by P. Demiéville (pp. 121-38)), but Pelliot gives no mention of this fragment.

49 For example, see $\mathrm{H}$. Maspero, 'Le dialecte de Tch'ang-ngan sous les T'ang', $B E F E O, \mathrm{XX}, 2$ (1920), pp. 1-124; B. Karlgren, Etudes sur la phonologie chinoise (=Archives d'Etudes Orientales, vol. 15); W. Simon, 'Zur Rekonstruktion der altchinesischen Endkonsonanten', MSOS, XXX (1927), pp. 147-67, ibid., XXXI (1928), pp. $175-204$.

50 A. Dragunov, 'The $h$ Phags-pa script and Ancient Mandarin', IAN, VII (1930), pp. 627-47, 775-97 ; H. Oshibuchi, 'Chügen On'in chū no Pasupaji nite utsusaretaru Kanjion ni tsuite', Ogawa Hakushi Kanreki Kinen Shigaku Chirigaku Ronso, pp. 601-41.

51 Les inscriptions mongoles inédites en écriture carrée $(=$ Collectanea Orientalia, 12).

52 'Quelques données nouvelles sur les relations entre les Mongols et les Ouigours', $R O$, II (1919/1924), pp. 240-7; 'Formules initiales des documents mongoles aux XIII.e et XIV-e ss.', $R O, \mathrm{X}(1934)$, pp. 131-57. 
Poppe's work was first written in Russian and then translated into Japanese. According to Poppe's preface to the Japanese edition, the original Russian text was published a few days after the beginning of Russo-German War in 1941, and he had fortunately retained one copy of the Russian edition. The Japanese edition, however, lacks the main part of his book, the texts of the inscriptions and the translations. In 1957 J.R. Krueger translated the whole text into English and, under Poppe's supervision, added some new materials to the new edition. This English edition includes thirteen 'Phags-pa texts and their transliterations, transcriptions, and translations, with exhaustive commentaries. ${ }^{53}$ Although most of the 'Phags-pa documents in Poppe's book had been studied since von der Gabelentz, it can be said that Poppe was the first to give a full account of these materials. He has also produced some articles on the 'Phags-pa script. ${ }^{54}$

Hattori's book was also damaged during the war. Two-thirds of his draft was destroyed by fire, and only the remainder was published in 1946. ${ }^{55}$ This book was intended as an approach to the Mongolian language of the Secret History of the Mongols through the Chinese transcription of Mongolian. As the first step in this attempt he tried to clarify the sound system of Chinese in the period between the Yüan and the early Ming dynasties, when the original text and the Chinese translation of this text were composed. In particular, description and analysis of the Mengku Tzu-yïn 蒙古字䫓(abbr. $M K T Y$ ) was made by Hattori for the first time. He concluded that the sound system employed in the MKTY was the Pien-ching 洁京 dialect transplanted to Lin-an 臨安 by the transfer

53 Istorija Mongol'skoj pis'mennosti. vol. I. Kvadratnaja pis'mennosti (Moscow/ Leningrad, 1941), 167 pp. Translated by S. Murayama and T. Yamazaki as 'Hôkeiji' Nihon Bunka, 35 (1955), pp. 236-187 (1-50), with Poppe's preface to the Japanese translation dated 2 April 1954. Translated by J. R. Krueger as The Mongolian Monuments in hP' ags-pa script (=Göttinger Asiatische Forschungen, 8).

54 'Popravka k čteniju odnogo mesta edikta vdovy Darmabala', Sbornik 'Pamjati akademiku N. Ja. Marra' (Moscow/Leningrad, 1939), pp. 239-43; 'Zolotoordynskaja rykopis' na bereste', Sovetskoe Vostokovedenie, II (1941), pp. 81-136 ; 'Die Sprache der mongolischen Quadratschrift und das Yüan-ch'ao pi-shi', $A M$, n.s. I, 1 (1944), pp. 97-115; 'The groups *uya and *uge in Mongol languages', SO, XIV, 8 (1950), pp. 1-15.

55 Genchōhishi no Mōkogo o arawasu Kanji no Kenkyu. 
of the capital. ${ }^{56}$ The $C Y Y Y$, the famous rhyme dictionary composed at almost the same time as the $M K T Y$, represented the sound system of the North, which is one source of modern Mandarin. In his analysis of the $M K T Y$, Hattori made an important contribution to Middle Chinese studies. Furthermore, his tentative romanisation of the 'Phags-pa alphabet is more accurate for dealing with Chinese documents in the 'Phags-pa script than any other romanisation which had ever been tried (see Table 1).

As to the Chinese transcription of the Mongolian language, Lewicki adopted Dragunov's method by using the Hua-i I-yü 華夷譯語. ${ }^{57}$ These attempts to relate 'Phags-pa transcriptions of the Chinese language and Chinese transcriptions of Mongolian and 'Phags-pa script have been successfully adopted by L. Ligeti.

Ligeti's first work, written in Hungarian, ${ }^{58}$ was never in general distribution, but his article on the Po-chia-hsing 百家姓 (abbr. $P C H$ ) in the 'Phags-pa script was an advance upon the achievements of Dragunov, Oshibuchi, and Lewicki and enriched the body of Chinese material in the 'Phags-pa script. ${ }^{59}$ Also, in another article, Ligeti gives a full account of three difficult problems concerning 'Phags-pa orthography in Mongolian and Chinese documents. ${ }^{60}$

Since the 1950s, more authentic and concrete materials such as the $M K T Y$ and $P C H$ have been available for reseach. In 1956 the $M K T Y$ based on a manuscript held in the British Museum was published in Japan. ${ }^{61}$ Also, in 1959 two texts of the $P C H$ were published in China : one based on the Chih-yüan 至元 edition and the other on the Genroku $\bar{\pi}$ 禄 edition (originally based on the T'ai-ting 泰定 edition) with a reproduction of the $M K T Y$ in the British Museum. ${ }^{62}$ Comprehensive introduc-

\footnotetext{
56 Ibid., pp. $36-58,66-75$.

57 La langue mongole des transcriptions chinoises du XIVe siècle ..., I (=Prace Wro:tawskiego Towaraystwa Naukowego A 29).

5s 'A 'phags-pa irásos nyelvemlékek', Emlékkünyv Melich János hetvenedik születésenapjára, pp. 222-37.

59 'Le Po kia sing en écriture 'phags-pa', $A O H$, VI (1956), pp. 1-52.

80 'Trois notes sur l'écriture 'phags-pa', $A O H$, XIII (1961), pp. 201-37.

61 Kansai Daigaku Tōzai Gakujutsu Kenkyūjo (ed.), Eiin Daiei Hakubutsukan zō Kyushōhón Mōkojiin.

${ }_{62}$ Lo ch'ang-p'ei and Ts'ai Mei-piao (ed.), Pa-ssu-pa-tsu yü Yüan-tai Han-yü.
} 
tions and commentaries on these texts and some more materials in the 'Phags-pa script, such as epigraphs held in the Peking University, coins, $p^{\prime} a i-t z u$, seals, etc., some of which were unknown, are given by Lo Ch'ang-p'ei and Ts'ai Mei-piao in this Chinese edition.

E.R. Hope's monograph in an attempt to criticise Karlgren and his followers deals in great detail with the existence of the glottal stop initial in Ancient Chinese. ${ }^{63}$ Hope's argument begins with the assumption that the $y$ ing initial 影 is a clear null pitch and that the $y \ddot{z}$ initial 咏母 is a muddy null pitch, both being vocalic anlaut with differences of tone pitch. He gives schedules to indicate how in 'Phags-pa transcriptions an alternation occurred between the $k, t, p, \ldots$ series and the $g, d, b, \ldots$ series. It is extremely difficult to summarise Hope's discussions, ${ }^{64}$ but this problem will be discussed later. As P.L.M. Serruys maintains, ${ }^{65}$ it is difficult to accept Hope's argument that Ancient Chinese had no glottal stop initial: he tries to deal with an extraordinarily wide field, from the Indic, Tibetan, Mongolian, and Chinese to Japanese with few references, ${ }^{66}$ so that his hypothetical conclusions lack any evident consistency.

Hope also discusses the problem of shapes in other scripts which are supposed to have been influenced by 'Phags-pa script; that is, the problem of Korean Önmun, Tibetan seal-characters, a certain variation of Manchurian script. As to the Korean Önmun, it has long been recog. nised that the letter shape of Önmun was influenced by the 'Phags-pa script, ${ }^{67}$ and Hope again pointed out this fact, using the theory of

63 Karlgren's Glottal Stop Initial in Ancient Chinese,...

${ }_{64}$ See K. Whinnom, review of this book, JOS, II (1955), pp. 158-72, which is rather a summary of Hope's work.

65 See Oriens, VIII (1955), pp. 135-41.

66 For instance, Hope does not use important reference by Pauthier, Chavannes, Francke, Walsh, Oshibuchi, Hattori, Lewicki, etc. mentioned above. He ought especially to have referred to Hattori's work in which the MKTY and its initial consonantal system are discussed.

67 See J.S. Gale, 'The Korean alphabet', Transactions of the Asiatic Society of Korea, IV (1912), pp. 13-61 ; K. Shiratori, 'Chōsen moji (Onmon) no kōzō ni tsuite', SZ, XLIII, 7 (1932), pp. 931-3 ; M. Courant, 'Systèmes d'Écriture en corée', ibid. , XXIII (1934), pp. 5-23; Hattori, op. cit, . p. 137. 
dichotomy between muddy and clear pitch sounds which he had sought to prove in his previous work. ${ }^{68}$

Li Te-ch'i presented some materials on Manchurian sigillary letters which seem to me to have been influenced by the 'Phags-pa script. ${ }^{69}$ Even after the fall of the Mongol Empire, the 'Phags-pa script was used in lamaist monasteries in Tibet and Mongolia for seals, so it is not surprising that the Manchurians who adopted the Uighur script with some modifications created sigillary letters by making their script square, and that the seal script would naturally resemble the 'Phags-pa script. ${ }^{70}$

As far as seals are concerned, most of the 'Phags-pa seals recently discovered are written in either Chinese or Tibetan, ${ }^{71}$ but the silver seal of Qan Olan-a ergïgdegsen, which was introduced by Rintchen, ${ }^{72}$ and which

63 'Letter shapes in Korean Önmun and Mongolian hPhagspa alphabet', Oriens, X (1957), pp. 150-9. Hope suggests that, some letters of the Önmun alphabet such as $l$, $m, n$, etc. might have been modelled on the Tibetan dbu-med series rather than the $d b u$-can series.

69 See Li Te-ch'i, 'Man-chou wen-tzu chih lai-yiuan chi ch'i yen-pien', PPTSK, V, 6 (1931), plate 9 (=lakiyaxa ulmengge fukjingga xergen 倠針管), plate 11(=seal of of Xan $i$ boobal) and plate 12 (=seal of Forgon be badarambure boobai).

70 See Ii Te-ch'i, ibid; L. Ligeti, 'A Propos de l'écriture mandchoue', $A O H$, II (1952), pp. 235-301. Besides, the official seal of the Dalai Lama shown in Walsh, 'Examples of Tibetan seals', pp. 5-4 is supposed to be a variant of the Uighur script, whose letter shape was made square, although this seal inscription is indecipherable.

71 On the seals in Chinese see W. Simon, 'A $h$ Phags-pa seal of $1295, ' A M, \mathrm{n}$. s. VI (1958), pp. 203-5 ; E. Haarh, 'L'écriture 'phags-pa vraiment carrée des sceaux chinois des Yüan', $A O, \mathrm{XXIV}, 1-2$ (1959), pp. 59-64; Ts'ai Mei-piao, 'Yung-chia fa-hsien Yüan-tai Meng-wen-yin k'ao-shih', WWTK, 89 (1958), pp. 42-3 ; S. Hasumi, 'Liang K'ai hitsu $L i$ Po Yin-hsing t'u no Pasupa moji "Ta-ssu-t'u-yin" to A-niko ni tsuite', THG, 35 (1968), pp. 83-97. On the seals in Tibetan see Francke, 'Ein Siegel in tibeto-mongolischer Schrift von Bhutan', 'Note on the Dalai Lama's seal', and 'Another version of Dalai Lama's seal'; Walsh, 'Examples of Tibetan seals' and 'Examples of Tibetan seals : Supplementary note'. The reproduction of two seals from a bank-note of the Ming dynasty shown in Walsh, 'Examples ...', p. 13, and another example from a bank-note which is illustrated in H. B. Morse, Trade and Administration of Chinese Empire (London: Ketly and Walsh, 1908), plate facing p. 141 are not written in 'Phags-pa (or Tibetan seal-) script but in Chinese characters, although Walsh suggests they are written in the Tibetan seal-script.

72 'A propos de la sigillographie mongole...', $A O H$, III (1953), pp. 25-31, esp. see p. 30 (=plate of this seal). The 'Phags-pa part of this seal is also written in Tibetan (Bstan-srid zun-'brel 'dzin-byed $\tilde{x} i$-'od-can rje-rgyal-po'i tha-ma-ka). 
is written in the Soyombo, ${ }^{73}$ Uighur and 'Phags-pa scripts, is worthy of note.

G.L.M. Clauson, who had already contributed to this field in collaboration with S. Yoshitake, ${ }^{74}$ clarified the phonetic value of each letter of the 'Phags-pa script in Chinese documents by using the thirty-six tzu-mu (initials) and some Mongolian inscriptions. ${ }^{75}$ P. B. Denlinger also tries to clarify the phonetic value of each letter of the 'Phags-pa script in the MKTY in comparison with Ligeti's treatment of the $\mathrm{PCH}{ }^{76}$ Some mistakes in both Clauson and Denlinger's articles will be discussed later.

The most recent contributions have been made by Y. Ozaki, P. Aalto, T. Keiya, Cheng Tsai-fa, and myself and, except for Aalto, all have dealt with the $M K T Y$ from the viewpoint of Chinese historical phonology. Ozaki maintained that the manuscript of the MKTY held in the British Museum was written during the $\mathrm{Ch}$ 'ien-lung reign (1736-95), basing his argument on the evidence of tabu characters, a Chinese philological tradition to prevent identification with emperors' names. Ozaki then mainly discussed the meaning of a certain passage in Chu Tsung-wen's preface to the MKTY, and suggested that in the thirteenth century the $k i$ - series had already undergone palatalisation. ${ }^{77}$

As far as I know, no 'Phags-pa seal written in Mongolian has been found except two Tibeto-Mongol seals. See G. L. M. Clauson, 'A Mongolo-Tibetan seal', JRAS, 1929, pp. 117-19.; J.R. Krueger, 'Three Oirat-Mongolian Diplomatic Documents of 1691', CAJ, XII, 4(1969), pp. 286-95.

73 On the Soyombo script, see Rintchen, op. cit. and 'Zwei unbekannte mongolische Alphabete aus dem XVII. Jahrhundert', $A O H$, II (1952), pp. 63-7+1 table+ 1 plate; G. Kara, 'Un texte mongole en écriture soyombo', $A O H$, IX (1959), pp. 1-38; Yuyama, op. cit, , p. 87.

74 'On the phonetic value of the Tibetan characters $\mathrm{ZV}$ and $\$$ and the equivalent characters in the hPhags. pa alphabet', JRAS, 1929, pp. 843-62 (cf. Hope, Karlgren's Glottal Stop Initial....., pp. 50-2, xi).

75 'The $h \mathrm{P}$ 'ags-pa alphabet', BSOAS, XXII (1959), pp.300-23.

76 'Chinese in hP'ags-pa script', $M S$, XXII (1963), pp. 407-33.

77 'Daiei Hakubutsukan-bon Mōkojiin sakki', Jinbun, VIII (1962), pp. 162-80. In this article Ozaki criticises A. Tōdō's hypothesis on palatalisation ('Ki- to tsi. no kondö wa 18 seiki ni hajimaru', $C G, 94$ (1960), pp. 1-3, 12). For further details on palatalisation in Chinese, see Tōdō, 'Development of Mandarin from 14c. to 
Aalto, who discussed the Mongolian translation of the Subhassitaratnanidhi, produced a brief but accurate sketch of the 'Phags-pa script in the Mongolian documents. ${ }^{78}$

Keiya deals in great detail with the process of the extinction of the final consonants $-k,-t,-p$ of the entering-tone in the MKTY. ${ }^{79}$ An outline of his successful argument will be introduced later.

Cheng Tsai-fa gave a full account of textual criticism of the $\mathrm{Ku}$ chin Yün-hui Chü-yao 古今韻會學要] and $M K T Y{ }^{80}$ He also provides useful materials for 'Phags-pa transcription, mainly textual criticism of 'Phagspa spellings, in Chinese documents. ${ }^{81}$

I also have treated the sound system employed in the $M K T Y,{ }^{82}$ but I have abandoned some ideas and developed others here.

The history of 'Phags-pa studies can thus be divided into three periods: the 1830 s to the 1920 s, the 1930 s to the 1940 s, and the 1940 s to the present. When 'Phags-pa studies began in the last century, the three aspects in the Mongolian, Chinese, and Tibetan languages were completely confused, but they have been treated separately since the 1920 s. In the future, however, as our studies progress, they should again be synthesised. It may be hoped, moreover, that materials for 'Phags-pa studies, epigraphs, seals, coins, etc. in Mongolian, Chinese, and Tibetan will be discovered and introduced. We may yet discover the original manuscript of the $M K T Y$, or some other, hitherto unknown, rhyme dictionary.

19c.', $A A$, VI (1964), pp. $38-46$.

78 'Quadrat-Inschriften', Mongolistik (= Handbuch der Orientalistik, Band V, Abschnitt II) (Leiden/Köln, 1964), pp. 104-7. Also see his ' $\mathrm{Zu}$ den Berliner TurfanFragmenten T III D 322, JSFOu, LXI, 6 (1959), pp. 3-21.

79 'Nisshō inbi shōshitsu no katei ni tsuite no ichi kasetsu, ...', NDBKR, XXXVII (1965), pp. 1-37.

so Meng-ku Tzu-yiin ken ken Pa-ssu-pa-tzu yu-kuan te yün-shu (=Kuo-li T'ai-wan Ta-hsüeh Wen-shih Ts'ung-k'an, 15).

81 'Pa-ssu-pa-tzu piao-chu Han-ÿ̈ ts'ai-liao chiao-k'an-chi', Symposium in Honor of Dr. Li Chi on his Seventieth Birthday, Part II, pp. 933-1003+6 plates.

82 'Mōkojiin no kenkyū,...', HDGGK, XI (1964), pp. 15-37. 


\section{A BIOGRAPHY OF BLA-MA 'PHAGS-PA}

$\S 1$. Sources

\section{A. CHINESE SOURCES}

1. Yüan-shih 元史, fasc. 202, 'Shih-Lao chuan 釋老傳' (abbr. YS)

Authors: Sung Lien 梁濂 and others

Date : 1370

Edition: Erh-shih-wu-shih 二十五史 (Shanghai : K'ai-ming Shu-tien, 1936-7), vol. 8, pp. 454-5

2. Yüan-shih Lei-pien 元史類編, fasc. 41, 'Tsa-hsing chuan 雜行傳' (abbr. YSLP)

Author: Shao Yüan-p'ing 邵遠平

Date: 1720 s.

Edition: Sao-yeh Shan-fang 掃葉山房, 1795 ed., pp. 15a-b

3. Hsin Yüan-shih 新元史, fasc. 140, 'Shih-Lao chuan 釋老傳' (abbr. $H Y S$ )

Author: K'o Shao-min 柯劯莣

Date : 1919

Edition: Erh-shih-wu-shih, vol. 8, pp. 461-2

4. Fo-tsu Li-tai T'ung-tsai 佛租歴代通载 (abbr. FLT), fasc. 21, '[Fa-ssu-pa] Hsing-chuang [登思八] 行狀' (abbr. $H C$ )

Authors: Wang P'an 王整 and others

Date: 1280(?)

Edition: Taishō, No. 2036, vol. XLIX, pp. $707 \mathrm{~b}-\mathrm{c}$

5. Ibid., fasc. 22, 'Ti-shih tien-pei 帝師殿碑' (abbr. TSTP)

Author: Shih-yüan Tsung-chu 釋源宗主

Date : 1321

Edition: Taishō, No. 2036, vol. XLIX, pp. 732c-3b

6. Ch'ih-hsiu Po-chang Ch'ing-kuei 栜修百丈清規, fasc. 2, 'Ti-shih

Nieh-p'an 帝師涅槃' (abbr. TSNP)

Author: Te-hui ch'an-shih 德輝解師

Date: 1360 s(?)

Edition: Taishō, No. 2025, vol. XLIIX, p. 1117a-c 
7. Chih-yüan Pien-wei lu 至元辯䧦錄, vols. 3,4

Author : Hsiang-mai 㮖革

Date : 1291

Edition: Taishō, No. 2116, vol. LII, pp. $770 \mathrm{c}-4 \mathrm{c}$

8. Shih-chien Chi-ku-lüeh hsï-chi 䆁鑑稽古略續集

Editor : Huan-lun 幻輪

Date : 1627

Edition: Taishō, No. 2038, vol. XLIX, p. 906b-c

B. TIBETAN SOURCES

9. Hu-lan deb-ther or Deb-ther dmar-po (The Red Annals)

Author: Kun-dga' Rdo-rje

Date : 1346

Edition: The Red Annals, Part I (Gangtok : Namgyal Institute of Tibetology, 1961), fol. 22a

Translations :

(1) English: S. Inaba, 'The Lineage of the Sa skya pa. A Chapter of the Red Annals', Memoirs of the Research Department of the Töyō Bunko, No. 22 (Tokyo: The Tōyō Bunko, 1963), pp. $107-23$ (abbr. $R A$ )

(2) Japanese : S.Inaba and H. Satō, Hu-lan deb-ther-Chibetto Nendaiki フゥラン・テブデー—チベット年代記 (Kyoto：Hōzōkan, 1964), pp. 117-9, 129-33

10. Bod-kyi yul-du chos dan cho-smra-ba ji-ltar byun-ba'i rim-pa debther snon-po, short title Deb-ther snon-po (The Blue Annals) (Tōhoku, No. 7036)

Author: 'Gos-lo-tsa Gźon-nu-dpal

Date: $1476-8$

Translation: G. N. de Roerich, The Blue Annals, Part IC=Monograph Series of the Royal Asiatic Society of Bengal, vol. VII) (Calcutta: The Society, 1949), pp. 210-12 (abbr. BA)

11. Gáns-can-yul-gyi sa-la spyod-pa'i mtho-ris-kyi rgyal-blon gtso-borbyas-pa'i deb-ther, Rdzogs-ldan gźon-nu'i dga'-ston, generally known as Rgyal-ba lna-pa'i chos-byun (The Fifth Dalai Lama's Chronicles) ( Tōhoku, No. 5664) (abbr. VDL) 
Author: Nंag-dban blo-bzan rgya-mtsho (The Fifth Dalai Lama)

Date: 1643

Translation: G. Tucci, 'From the Fifth Dalai Lama's Chronicles', Tibetan Painted Scrolls (abbr. TPS), II (Roma: La Libreria dello Stato, 1949), pp. 625-51

12. Dbus-gtsan-gi gnas-rten rags-rim-gyi mtshan-byain mdor-bsdus dad$p a^{\prime} i$ sa-bon

Author: Dge-bśes karma bkra-śis chos-'phel

Date: 1892

Translation: A. Ferrari, Mk'yen brtse's Guide to the Holy Places of Central Tibet (=Serie Orientale Roma, XVI) (Roma : Istituto Italiano per il Medio ed Estremo Oriente, 1958), text, pp. 1-33; translation, pp. 37-76

C. MONGOLIAN SOURCES

13. Qad-un ündüsün-ü Erdeni-yin Tobči (abbr. EYT)

Author: Saran Sečen Qong Tayi ǰ

Date: 1662

Translations :

(1) Chinese : Chi Yün 紀旳 and others and annotated by Shen Tseng-chih 沈曾植 and Chang Erh-t'ien 張爾田, Meng-ku Yüan-liu Chien-cheng 蒙古源流篦證 (Taipei : Wen-hai Ch'upan-she, 1965. repr. based on the Ch'an-shou-chai chiao-ting pen 桪守栾校訂本, 1789 ed.), pp. 171-81

(2) German: I. J. Schmidt, Geschichte der Ost-Mongolen und ihres Fürstenhauses (St Petersburg: N.Gretsch/Leipzig:C. Cnobloch, 1829), pp. 110-9

(3) Japanese : M. Gō 江實, Mōko Genry $\bar{u}$ Yakuchū 蒙古源流譯註 (Tokyo: Kōbundō, 1940), pp. 70-5

(4) English: J. R. Krueger, History of the Eastern Mongols to 1662 (= The Mongolia Society Occasional Papers, No. 2),part 1. (Bloomington :The Mongolia Society, 1967, 2nd ed.),pp. 73-7

14. Jirüken-üTolta (Tib. Sñin-tshil) (The Jewel of the Heart)

Author: Chos-kyi 'Od-zer

Date of Mongolian tr. : 1723-35 
Text: A.M. Pozdnejev, 'Mongol'skaja Xrestomatija pervonačal'nago prepodavanija', Izdanija Fakul'teta Vostočnyx' Jazykov' lmp. S. -Pet. Universiteta, No. 7 (St Petersburg, 1900), pp. 360-79

15. Dai yüwen ulus-un bolor erike

Author: Rasipungsur

Date : 1774-5

Text: Bolor Erike (= Scripta Mongolica, III)(Cambridge, Mass.: Harvard University Press, 1959), Part I, pp. 171-2; Part IV, pp. $121-2$

16. Hor-chos-byun

Author: 'Jigs-med rig-pa'i rdo-rje

Date : 1819

Translation: G. Huth, Geschichte des Buddhismus in der Mongolei. Mit einer Einleitung: Politische Geschichte der Mongolen, II (Strassburg: K.J. Trübner, 1896), pp. 118-36

\$ 2. Sa-skya-pa_-Ancestors of Bla-ma 'Phags-pa

Bla-ma 'Phags-pa was descended from the Sa-skya-pa clan of Tibet. ${ }^{1}$ According to Tibetan chronicles, the earliest ancestor of this clan was Jo-bo 'Khon-par skyes ('The Lord Born Amidst Quarrels')' who was a son of gYa'-span skyes-gcig of Yar-kluñ-sar by Si-li-ma. 'Khon dpal-poche, a son of Jo-bo 'Khon-par skyes, was appointed 'Confidential Minister' (nan்-blon) to King Khri-sron lde-btsan. ${ }^{3}$ He had four sons: Khri-mdzes lha-legs, Tshe-la dban'-phyug, 'Khon klu'i dbań-po bsruń-ba, and Tshe-'dzin.

1 The Sa-skya-pa is one of the four largest Buddhist clans of Tibet (Rñin-ma-pa, Bka'-brgyud-pa, Dge-lugs-pa, and Sa-skya-pa) and occupied the south-west part of Gźis-ka-rtse. This clan was founded by Dkon-mchog rgyal-po in Sa-skya, west of Bkra-Sis Lhun-po, in 1072. For further details, see TPS, I, pp. 81-93, 'The Sects'. On the geography of Tibet, see A. Ferrari, op. cit., Map. A.

$2 R A$, p. $170 ; B A$, p. 210 .

3 This passage perhaps corresponds to the following passage in Chinese sources; TSTP says: 'In ancient Tibet, there lived a "National Preceptor" (kuo-shih) Ch'an-heng-lo-chi-ta 禪恒羅吉達 ( $H C$, Ch'an-t'a-lo-chi-ta 禪怛倠乞答), who gained an accurate knowledge [of Buddhism] and had miraculous powers. Each generation [of his descendants] has successively conducted itself in the correct [Buddhist] way. The kings [of Tibet] have for generations respected them as preceptors.' Ch'an-heng (or t'a)-lo-chi-ta in the Chinese sources cannot be identified. Frior to the above passage, these sources state: 'After about seventeen generations, this 
The descendants of Rdo-rje rin-po-che, ${ }^{4}$ a son of Tshe-'dzin, were Ses-rab yon-tan, Yon-tan 'byun-gnas, Tshul-khrims rgyal-po, Rdo-rje gtsug-tor, Dge-skyabs, Dge-mthon, Bal-po, and Śăkya blo-gros. They were all well versed in the Old Tantric texts. Sakyya blo-gros had two sons: the elder, Ses-rab tshul-khrims, became a monk; the younger, Dkon-mchog rgyal-po, who was born in the year Wood-Male-Dog (sin-pho-khyi, i.e. $1034),{ }^{5}$ founded the monastery of Sa-skya in the year Water-Male-Mouse (chu-pho-byi-ba, i.e. 1072). ${ }^{6}$ Dkon-mchog rgyal-po's son, Sa-chen Kundga' sñin-po, was born in the year Water-Male-Ape (chu-pho-spre'u, i. e. 1092), and learned the doctorine from 'Jam-dbyańs (Skt. Mañjughoșa), Bir-wa (Skt. Virüpa) and others. ${ }^{7}$ Sa-chen had four sons: in order of age, Kun-dga' 'bar, ${ }^{8}$ Slob-dpon rin-po-che Bsod-nams rtse-mo, Rje-btsun Grags-pa rgyal-mtshan, and Dpal-chen 'od-po.

Of the sons of this last, the eldest was Sa-skya pandita Kun-dga' rgyal-mtshan dpal-bzan-po, ${ }^{9}$ who was born in the year Water-Male-Tiger

family] arrived at Sa-ssu-chia-wa 薩斯加哇 (Sa-skya pandita).' But reckoning seventeen generations backwards from Sa-skya pandita, we find no trace of his ancestors in the Tibetan chronicles.

4 YS states: 'Legend says that more than ten generations ago, ['Phags-pa's] ancestor To-li-ch'ih 架栗赤 helped the kings [of Tibet] to conquer the West (Tibet) by the [Buddhist] law.' To-li-ch'ih in the above quotation must be identified as Rdo-rje [rin-po-che].

5 As to the Tibetan and Mongolian chronology, see K. Grønbech and J. R. Krueger, An Introduction to Classical (Literary) Mongolian (Wiesbaden: O. Harrassowitz, 1955), pp. 102-6; P. Poucha, 'Mongolishe Miszellen. VII : Innerasiatishe Chronologie', CAJ, VII (1962), pp. 192-204; C. Vogel, 'On Tibetan Chronology', CAJ, IX (1964), pp. 224-38; L. Petech, 'The Dalai-Lamas and Regents of Tibet: A Chronological Study', TP, XLVII (1959), pp. 368-94.

s $B A$ (p. 210) states that this was in the year Water-Female-Ox (chu-mo-glan, i.e. 1073).

$7 B A$ makes no mention of this.

$8 B A$ (p. 211) states: 'Kun-dga' 'bar went to India, was a learned man, and died in India at the age of 22 .'

$9 B A$ mentions his name as Sa-skya pan-chen (Kun-dga'-rgyal-mtshan). FLT, fasc. 22 (Taisho, No. 2036, vol. XLIX, p. 725c) states: 'When Shih-tsu 世祖 (Qubilai) was still in the Heir Apparent's Palace, hearing about $\mathrm{Ch}^{\prime} \mathrm{o}$-li-che-wa 絙 理哲瓦 (Tib. Chos-rje-ba) in the West (Tibet).' Hor-chos-byun mentions his name as Dharma-svāmin ('Master of the Law') which corresponds to the Tibetan Chos- 
(chu-pho-stag, i.e. 1182).$^{10}$ He learned the five vidyās ${ }^{11}$ under the guidance of Paṇ-chen Śãkyaśrībhadra and many other learned men. ${ }^{12}$ Having given Bla-brań śar-pa to Śer- 'byun, he founded Bźi-thog and lived there. ${ }^{13}$ Prince Godan of Mongolia, who was suffering from leprosy, dispatched an envoy named Doorda Darqan ${ }^{14}$ and requested him to come to

rje-ba (Huth, p. 141) (cf. Mahāoyutpatti, No. 18). According to VDL, 'he (Saskya-pandita) received the rules of perfect investiture with the great Kashmiri paṇtita Sākyaśrïbhadra, and adding the abbot's title to his name of Kun-dga' rgyal-mtshan, he puts: dpal-bzan-po (=\$rī-bhadra) after his name.' (TPS, II, p. 626 a)

10 In his translation of the Hor-chos.byun Huth (p. 118) miscalculates the year of Sa-skya pandita's birth as A.D. 1181, which is now to be amended to A. D. 1182 . See P. Pelliot, 'Le cycle sexagénaire dans la chronologie tibétaine', $J A$, mai·juin, 1913, pp. 633-67, esp. 655-7.

11 See Mahāvyutpatti, Nos. 1554-9, i.e. Śabda-vidya (sheng.ming 聲明=phonology), hetu-vidya (in-ming 因明 = logics), adhyātma vidy $\bar{a}$ (nei-ming 述明=philosophy), cikitsā-vidy $\vec{a}$ (i-ming 醫明 = medicine), and silpa-(kasma-)sthāna-vidy $\bar{a}$ (kung. (ch'iao)ming 工(项)明=arts). The Mongolian source $E Y T$ also mentions this as tabun uqa $a_{\text {an }}$ (Schmidt, p. 110, line 14), which is translated as 'fünf Wissen. schaften' (Schmidt, p. 111), 'wu-shih 五識' (Chien-cheng, vol. 4, p. 172), and 'gorui no gaku 五類の學' (Gc̄, p. 70). YS states: '['Phags-pa] was very intelligent and comprehended the wu-ming 五明 (five vidyäs, cf. Mahävyutpatti, No. 1554) from childhood; so thus he was also called Pan-mi-t'a 班帮怛.' This passage in the YS is very likely a mistaken account of Sa-skya pandita taken from Tibetan chronicles or legends. Pan-mi-t'a, which seems to correspond to the Skt. pandita, is not 'Phags-pa's title but that of Sa-skya Kun-dga' rgyal-mtshan. G. Pauthier takes Pan-mi-t'a in the $Y S$ as equivalent to the Skt. paramita ('De l'alphabet de Pa'-sse-pa, ..., p. 10, n. 2). There have been some cases of confusion between Sa-skya pandita and 'Phags-pa, which have probably arisen on account of this passage in the YS; for example an annotation added to the Chien-cheng (vol. 4, p. 172, 6-9) mistakenly declares a biography of Sa-ska pandita in the TSNP to be that of 'Phags-pa, and gives Sa-skya pandita's title as Pa-ke-pa Pa-la-mi-t'e 帕克 巴巴剩密特 ('Phags-pa pāramita). 巴喇密特 can only be taken as pāramita, but it seems to be a confusion of pandita. with pāramita. made by the Chinese, as shown in pan-mi.t'a (pandita./päramita.).

12 EYT states that Sa-skya pandita went to India (Mong. Enedkeg) to study under Pañ-chen Săkyasrïbhadra. But, in fact, he did not go to India. In 1208 he became a student of Paṇ-chen Śakyaśrīibhadra, who was in Tibet between 1204 and 1214 (see n. 9). For further details, see Okada, op. cit., p. 101.

13 See $R A$, p. 108 ; Ferrari, op. cit, p. 150 , n. 500.

14 See Schmidt, p. 111; TPS, I. p. 9a-b. His Tibetan name is Rdo-rta-nag, and he attacked Tibet in 1240. 
Mongolia. ${ }^{15}$ This was just as had been previously prophesied by Rjebtsun Grags-pa rgyal-mtshan, who said:

At some later age, from the North, a man whose language is different, wearing a hat which looks like a falcon flying and putting on shoes like the nose of a hog, will issue an invitation and render service to the teaching. 16

When Sa-skya pandita was aged sixty-three, in the year Wood-MaleDragon ('sin-pho-'brug, i.e. 1244), ${ }^{17}$ he started towards the North with his two nephews, 'Phags-pa and Phyag-na. ${ }^{18}$ They reached Liang-chou 涼州 in the Horse year (ria, i.e. 1246) ${ }^{19}$ Prince Godan returning from the 'Great Conference' (Mong. quriltai) and the Coronation of Güyük Qan (Tib. Go-yug), ${ }^{20}$ met Sa-skya pandita in the Sheep year (1247). ${ }^{21} \mathrm{He}$ carved an image of Avalokiteśvara Bodhisattva Siṃhanādin ${ }^{22}$ and gave a

15 See Schmidt, p. 111. This passage suggests the Prince Godan cordially invited Sa-skya pandita. But in fact, the Mongolian court threatend Sa-skya pandita saying that if he did not go to Mongolia, the Mongols would have to attack Tibet. See TPS, I. p. 9; Okada, op. cit., pp. 97-9.

$16 R A$, p. 108 . This episode is also mentioned in $E Y T$, Bolor Erkike and Jiriken.

it Tolta. See Okada, ibid., pp. 100-6.

$17 B A$ (p. 211) states: 'At the age of 63 in the year Wood-Male-Dragon (1244) he visited the Emperor (i.e. Godan in Kan-su)'.

$18 R A$, p. $109 ; B A$, p. 212 . Chinese sources do not mention Phyag-na.

19 EYT mentions the years of Sa-skya pandita's departure from Tibet and meet. ing with Godan, but does not record the year of his arrival in Mongolia. On Liang-chou, see n. 32 .

20 See 'Ting-tsung pen-chi 定宗本紀' of YS; i.e. 'In the first year [of Ting-tsung] (1246), autumn, seventh month, [Ting-tsung] mounted the Imperial throne.' Ting. tsung corresponds to Güyük Qan. EYT makes a miscalculation, ascribing the reigns of each Qan as follows:

$\begin{array}{cll}E Y T & & \text { real reign } \\ 1189-1227 & \text { Činggis Qan } & 1206-1227 \\ - & \text { Tului (Prince Regent) } & 1228 \\ 1227-1233 & \text { Ögedei Qan } & 1229-1241 \\ - & \text { (Queen of Ögedei) } & 1242-1245 \\ 1233 & \text { Güyük Qan } & 1246-1248 \\ 1234-1251 \text { (Godan Qan) } & \text { (Queen of Güyük) } & 1249-1250 \\ 1252-1260 & \text { Möngke Qan } & 1251-1260 \\ 1260-1294 & \text { Qubilai Qan } & 1260-1294\end{array}$

21 This accords with the description in EYT. BA gives no mention of this.

22 EYT (Schmidt, p. 113). In Schmidt's text, this is mentioned as Arslan 
consecration to Prince Godan. Sa-skya pandita gained the highest rank of the servants of Heaven, and propagated Buddhism throughout Mongolia. ${ }^{23}$ At the age of seventy, in the year Iron-Female-Hog (lcags-mophag, i.e. 1251), he passed away in the North. ${ }^{24}$

\section{§ 3. Bla-ma 'Phags-pa}

Sa-skya pandita's youngest brother was Zañs-tsha bsod-nams rgyalmtshan, ${ }^{25}$ born in the year Wood-Male-Dragon ('sin-pho'brug, i. e. 1184). He had two sons by his wife Jo-mo dkon-mchog-skyid; 'Gro-mgon 'Phags-pa Blo-gros rgyal-mtshan and Mńa' bdag phyag-na rdo-rje. He also had a daughter Slob-dpon-ma mdo-sde and a son Slob-dpon Rin-chen rgyal-mtshan by another wife Jo-mo 'bro. ${ }^{26}$ Zanis-tsha died at the age of fifty-six in the year Earth-Female-Hog (sa-mo-phag, i.e. 1239).

'Phags-pa was born in the year Wood-Female-Sheep (śnin-mo-lug, i.e. 1235). ${ }^{27}$ When he was seven years old, he was already able to recite a few hundred thousand words of scriptures and to understand their con-

Daquda Qomsim Bodhisatu, in which Qomsim is a Mongolian corruption of Chinese kuan-shih-yin 觀世普 (the character 岳 was pronounced $y i m$ in the Yüan period) [In Mongolian, the final $m$ sometimes alternates with $n$. See N. N. Poppe, Introduction to Mongolian Comparative Studies (=Suomalaise-Ugrilaisen Seuran Toimituksia, 110) (Helsinki: Societé Finno-Ougrienne, 1955), p. 101.]. The Chien-cheng (p. 173, line 10) translates this as 獅吼觀晋 which corresponds to the Skt. original term, but Schmidt does not transcribe the whole Mongolian term but only Chongschim Bodhisatwa (p. 113). Cf. Mahāvyutpatti, No. 685.

23 Sa-skya pandita is said in the Hor.chos-byun to have created a new Mongolian script between 1247 and 1251 (Huth, pp. 133-4). See 'Introduction'.

$24 V D L$ states the place of his death as Sprul-pa'i-sde (TPS, II, p. 626a). BA (p. 511) says that Sprul-pa'i-sde is one of the four monasteries in the vicinity of Liang-chou. According to Roerich (Mun-mkhyen Čhos-kyi hod-zer and the origin of the Mongolian alphabet', p. 54), Sprul-pa'i-sde was situated east of Liang-chou, and the stüpa (sku-gdun mchod-rten) containing his mortal remains is still preserved in the semi-ruined monastery.

25 His name is mentioned in TSNP as So-nan-kan-tsang 唆南紺藏 which corresponds to [Zañs-tsha] bsod-nams rgyal-mtshan. (The character 南 was pronounced as nam in the Yüan period.)

26 BA makes no mention of his wives and daughter.

27 YS and $H C$ do not state the year of his birth. But TSNP says: '[he]was born on the thirteenth day of the fourth month in the year of Chi.hai 己永 (1239)', and this accords with the following passages; YS, 'In the year Kuei-ch'ou 癸\# (1253), 
tent. $^{28}$ People called him an infant genius, so he was named 'Phags-pa. ${ }^{29}$ He was also called Pan-mi-t'a 班㢾怛. ${ }^{30}$

In 1244 , at the age of ten, ${ }^{31}$ he and his younger brother Phyag-na followed their uncle, Sa-skya pandita, in his journey to the North. They reached Liang-chou 涼州. ${ }^{32}$ Since Sa-skya paṇita met Prince Godan in 1247 and became a monk of the highest rank, 'Phags-pa is supposed to have remained in Liang-chou even after the death of his uncle in 1251.

when he was fifteen years old, ..'; HC, 'In the year Keng-shen 庚申 (1260), he was twenty-two years old, ...' According to Chinese sources, the year of 'Phags. pa's birth was very likely 1239 . Inaba follows this $(R A$, p. 116, n.38 'Gen no teishi ni kansuru kenkyü,...', ODKN, XVII (1964), p. 102). However, according to the $R A$ and $B A$, Zans-tsha bsod-nams rgyal-mtshan, 'Phags-pa's father, died in 1239. Moreover, Mna'-bdag Phyag-na rdo-rje and Slob-dpon Rin-chen rgyal-mtshan, 'Phags-pa's younger brothers, were born in 1239 and 1238 respectively. If only Chinese sources are followed, the years given for his father's death and his brothers' births would lack consistency, unless 'Phags-pa and Phyag-na were twins and Rin-chen was elder-step-brother of 'Phags-pa. Therefore I prefer to follow the Tibetan sources. EYT also gives the year of his birth as 1235 (Schmidt, p. 115).

28 See YS. TSNP states: '[When he was] seven years old, [his] comprehension of the [Buddhist] laws and expansion of [Buddhist] knowledge had [already been] completed.'

29 In the Chinese sources, the name 'Phags-pa is transcribed as Pa-ssu-pa 八思巴 (YS), Pa-ho-ssu-pa 八合斯八 (YS, 'Shih-tsu pen-chi 世祖本紀’), Fa-ssu-pa 發思八 (HC, Shih-chien Chi-ku-lüeh hsï-chi), Pa-ssu-fa 拔思發 (TSTP), Pa-ho-ssu-pa 拔 合斯八 (TSNP), etc. The word 'Phags-pa originally means the 'distinguished', 'ex. cellent', 'glorious' and refers to 'holy persons, things, places, etc; title of saints, and teachers of religion' (H.A. Jäschke, A Tibetan-English Dictionary, p. 355b), which corresponds to the Skt. ärya-. See n. 11.

30 YS. This is supposed to correspond to the Skt. pandita. See n. 11.

$31 B A$, p. 212. $R A$ (p. 108) states: 'At the age of 9 , he proceeded to the North in the retinue of his uncle.' 'Phags-pa was born in 1235; therefore in 1244 he should have been in his tenth calendar year.

32 Hor-chos-byun (Huth, p. 133) states: 'Er (Sa-skya pandita) begab sich daher im 65. Lebensjahre, (männlichen)Feuer-Pferde-Jahre(1245)[read 1246], nach dem grossen Palaste Lan ju.' But Roerich (op. cit., p.53)states: '... Tibetan transcriptions Lan-ju $\sim$ Lañ-gru (pron. Lay-d'u) Lyañ-ju stand for Liang-chou in Kansu, in the vicinity of which still stands the ruined monastery of Sprul-pa'i-sde, the former residence of the Sa-skya pandita.' Moreover, FLT, fasc. 22 (Taisho, XLIX, p. 725c, line 23ff.) states: 'When Shih-tsu (Qubilai) was still in the Heir Apparent's Palace, hearing about Ch'o-li-cho-wa 線理哲瓦 (Tib. Chos-rje-ba) in the West (Tibet), ... he dispatched an envoy to Hsi-liang 西涼 (=Liang-chou), where the King Godan was 
In 1253 , when 'Phags-pa was aged nineteen, ${ }^{33}$ Prince Qubilai dispatched an envoy to Prince Godan in Liang-chou, and asked to see Sa-skya paṇita. As Sa-skya paṇdita had already passed away, Prince Godan recommended 'Phags-pa to Qubilai. ${ }^{34}$ Prince Qubilai sent an escort of one hundred Mongolian cavalrymen to Liang-chou. ${ }^{35}$ Thus, 'Phags-pa was received in audience by Prince Qubilai at his Palace in Lu-pa'i-śan. ${ }^{36}$ From that time on, Prince Qubilai and 'Phags-pa were closely associated, the one as material patron, the other as spiritual guide and refuge (mchod). He gave the consecration of Kei Vačir to Qubilai. ${ }^{37}$ In the year Wu-wu 戊午(1258), when 'Phags-pa was twenty-four years old, he attended a big conference between Buddhists and Taoists to engage in polemical discussion of the books Hua-hu-ching 化胡經 and some others.

living,' Sa-skya pandita is supposed to have stayed with Godan after meeting him. Therefore, Lan-ju in the Hor-chos-byun is probably a mistake for Liang-chou.

33 YS states: 'In the year Kuei.ch'ou 癸丑 (1253), when ['Phags-pa] was fifteen years old, [he] was received in audience by Shih-tsu (Qubilai).' If the year of his birth was 1235, he should have been in his nineteenth calendar year. $B A$ gives his age in 1253 as eighteen.

34 See $F L T$, fasc. 22 (Taisho, XLIX, p. $725 \mathrm{c}$, line $25 \mathrm{ff}$. ).

35 See $R A$, p. 108.

36 Inaba does not identify this place name in the $R A$ or in his Japanese translation (in collaboration with $\mathrm{H}$. Satõ). This is supposed to be a Tibetan corruption of Liu-p'an-shan.六盤山, southwest of Ku-yüan 固原 prefecture in Kansu province. The 'Shih-tsu pen-chi' in the YS (Erh-shih-wu-shih ed. vol. 8, p. 11d) states: 'In the year of Chia-yen 甲家 (1254), on the date Keng-tzu 底尒 of the fifth month, [Qubilai] stayed at Liu.p'an-shan.' In the Tibetan documents, the Chinse character 六 is normally transcribed as lug which corresponds to the AC liuk. So it is possible that the Tibetans transcribed this character as $l u$ after dropping the final consonant $-k$ in Mandarin. $P a^{\prime} i$ is a genitive form of $p a$. It is supposed to have been influenced by the Tibetan nominal or verbal suffix $-p a(-b a)$ or by the northwestern dialect of Chinese $p$ 'an. See B. Csongor, 'Some Chinese texts in Tibetan script from Tun-huang', $A O H, \mathrm{X}$ (1960), No. 304 in 'Index' (喚, AC xuan; Tib. trsc. hwan, hwa). (But it is difficult to be sure whether this accords with ' $\mathrm{Lu}$. pe san (Liu.pin shan)' ( $B A$, II, p. 505).

37 According to the EYT, the first meeting was not very friendly ; in 1264 Qubilai's queen, Qubilga Čambui Gooa, suggested to Qubilai Qan that Mati Dhuvajwa (see n. 52) (Skt. Mati-dhvaja) should succeed to the post of Bla-ma (Mong. bogda), and that the Qan should receive the Kei vacir.u abisig (=Skt. hevajräbhişeka-); Mong. kei-vadir =Skt. he-vajra $\left[\right.$ [Tib. kye-rdo-rje, or dgyes. ${ }^{\circ}$ ]: Mong. kei, Tib. kye, dgyes $=$ Skt. he '(interj.) oh!' vacir=Skt. vajra $[$ [Tib. rdo-rje] 'thunderbolt' [hevajra., 
Möngke Qan commanded 'Phags-pa to analyse the discrimination of right or wrong laid down in those books. The Taoists could not continue the argument and were eventually defeated. ${ }^{38}$

In the first year of the Chung-t'ung 中統 reign (1260), Qubilai Qan ascended the throne. 'Phags-pa was appointed kuo-shih 國師 (National Preceptor) and was invested with a jade-seal. ${ }^{39}$ Thus, 'Phags-pa formally

name of a Tāntric deity or a work] ; Mong. abisig=Skt. abhişeka- 'consecration' [Tib. dban-bskur-ba] (cf. Mahãvyutpatti, No. 4306 金剛灌戒(金剛櫵頂); also F.D. Lessing, Mongolian-English Dictionary, pp. $4 \mathrm{~b}$ and $1174 \mathrm{a}$ ). The Qan agreed with her, but objected to sitting under 'Phags-pa to receive this consecration, but finally consented to do so. Furthermore, when the Qan and 'Phags-pa discussed the tantra of Kei-vazir (hevajra-tantra, see above), 'Phags-pa could not understand the words of the Qan, who kept the only scroll of it. In the night Mahākāla's apparition (see Mahavyutpatti, No. 3162) brought this scroll to 'Phags-pa. On the next day, the Qan could not equal him in argument. Thus Qubilai Qan came to respect him. For further details, see Schmidt, pp. 114-7.

38 See $H C$ which states: 'In the year of $W u$-wu (1258), when he was twenty [read twenty.four] years old, Buddhists and Taoists discussed on the Hua-hu-ching. Hsien-tsung 赖宗 (Möngke Qan) commanded them to analyse the right or wrong [of this book]. The Taoists could not reply.' For this argument between Buddhists and Taoists, details are given in the Pien-wei lu by Hsiang-mai. In 1222 Cinggis Qan invited to his court Ch'ang-ch'un chen-jen 長春真人 (Chi'u Ch'u-chi fr 處機, 1148-1227), a famous patriach of the Ch'ian-chen 全貪 sect of Taoism. Therefore, the Taoists, mainly followers of Ch'ang-ch'un chen-jen, had continuously attacked the Buddhists; destroying nearly five hundred Buddhist monasteries and changing them into Taoist shrines. Conversely, the Buddhists also burnt Taoist apocrypha and recaptured monasteries occupied by the Taoists. Möngke Qan issued an edict prohibiting the Taoists' subversive activities against Buddhism, but it was of no effect. According to the Pien-wei lu, in the year of Ting-ssu $丁 \mathrm{E}$ (1256), Möngke Qan convened several hundred representatives of the Buddhists, Confucians, and Taoists in the Palace. 'Phags-pa also attended this conference (Taisho, LII, 771a, line 7ff.) and asked the Taoists to explain the essence of Taoism and its miracles (Taisho, LII,771c, line 16-772a, line 3). After the conference, Möngke Qan again issued an edict saying that Taoists apocrypha such as the Hua-hu-ching, Pa-shih-i-hua-t'u八十一化圖, etc. should be burnt. For further details, see, for example, the following works : Li Chih-ch'ang 李志常 Ch'angch'un chen-jen Hsi-yu-chi 長春真人西遊記 (1228) (Wang Kuo-wei 王國維, Hai-ning Wang Ching-an hsien-sheng I-shu 海然王静安先生遗書, fasc. 39); Yeh-lü Ch'u-ts'ai 耶律楚材, Hsi-yu-lu 西遊錄 (1228) (Lo Chen-yü 羅振玉 ed. based on the Kanda Kiichirō 神田喜一郎 ed., 1927); Ts'ai Mei-piao, Yüan-tai Pai-hua-pei Chi-lu (Peking, 1955), pp. 101-6; S. Nogami, 'Gendai Dō-Butsu nikyõ no kakushitsu', $O D K N$, II (1943), pp. 213-75.

39 YS ('Shih-tsu pen-chi') states : 'On the twelfth month of the first year of Chung- 
started to control Buddhism in Mongolia. In 1265 he returned to Tibet, ${ }^{40}$ but in 1268 , he was again invited to Mongolia. ${ }^{41}$ Having been commanded by Qubilai, 'Phags-pa invented a Mongolian script and presented it to the throne. ${ }^{42}$ This new script was promulgated by Imperial decree in

t'ung, ... Shih-tsu (Qubilai) appointed the Tibetan priest Pa-ho-ssu-pa 八合思八 ('Phags-pa) to [the position of] $t i$-shih 帝師.' $T i$-shih in this quotation should be corrected to kuo-shih. The $R A$ (p. 108) gives no accurate account of the years of his appointments to kuo-shih and ti-shih. The $B A$ (p. 212) also mistakenly states: 'when Se-chen (Qubilai) had ascended the imperial throne, he ('Phags-pa) became Imperial Preceptor', and the VDL (TPS, II, p. 626b) follows this. $H C$ and TSNP state: '[Qubilai who] respected ['Phags-pa] appointed him kuo-shih, and invested him with a jade-seal. [Also Qubilai] appointed him Chung-yüan fa-chu 中 原法主: This title, Chung-yuian fa-chu, probably corresponds to the Tibetan rgyal-khams-kyi bdag-po (RA, Namgyal Institute ed. fol. 22a, line 5; $R A$, p. 108 translates this as the Chief Preceptor of the Kingdom). EYT states that Qubilai, who received four consecrations from 'Phags-pa, gave him the title Sang sing tai wang kuosiri (Chin. San-hsing ta-wang kuo-shih 三省大王國師; Tib. khams.gsum chos-rje rgyal-po bla-ma 'phags-pa ; Mong. Gurban gajar daki nom-u garang ulemji blama) (Schmidt, pp. 116-17; Gō, p. 74; Krueger, p. 76. Krueger's hsing hsing tai wang kuo-shiri must be corrected to san hsing...). The presents which 'Phags-pa received from Qubilai listed in the EYT accord with those in VDL (TPS, II, p. 626b).

40 See $B A$, p. 212 . $H C$ gives no accurate account of the year of his return to Tibet.

41 See $B A$, p. 212 .

42 It is difficult to ascertain the year in which the "Phags-pa script was invented. YS states: 'In the first year of the Chung-t'ung reign (1260), ...Qubilai appointed him kuo-shih,...[Qubilai] commanded 'Phags-pa to invent a new script. He did so and presented it to the throne. This script includes about a thousand words and consists of forty-one [alphabetical] signs.... In the sixth year of the Chih-yüan reign (1269), [this new script] was promulgated by Imperial decree.' On the other hand, $H C$ and TSNP state: 'In the seventh year of the Chih-yüan reign (1270), [Qubilai] commanded him to invent a Mongolian script. He was absorbed in tracing lines, [and after a few days (TSNP)] he completed it. [This script] satisfied [Qubilai's] intention, and was immediately promulgated by Imperial decree.' The date of the promulgation of the 'Phags-pa script was possibly the second month of the year Chi-ssu 己ᄅ (March/April, 1?69) as YS ('Shih-tsu pen-chi') and FLT, 21 (Taishō, XLIX, 705b, lines 3-4) state. Ts'ai Mei-piao (Yüan-tai Pai-hua-pei Chi-lu, pp. 23-4, n. 1; Pa-ssu-pa-tzu yü Yüan-tai Han-yü, p. 9) maintains that this script is supposed to have been tentatively used in 1268, because The Edict of Chou-chih Ch'ung-yang Wan-shou-kung 鳌屋重陽萬壽宮聖旨碑 in the 'Phags-pa script is dated the year of Dragon, which corresponds to 1268 . But this cannot be cited as evidence because it is quite possible that the epigraph dated 1268 was actually carved after 1269 . VDL states: 'He ('Phags-pa) returned to the imperial 
1269.43 'Phags-pa was promoted to $t i$-shih 帝師 (Imperial Preceptor) and was given a title of ta-pao fa-wang 大寶法王. ${ }^{44}$ Qubilai again invested him with a jade-seal.

Then he again returned to Tibet, ${ }^{45}$ and in the eleventh year of Chihyüan reign (1274), Qubilai dispatched an ambassador to invite him. At the end of this year, 'Phags-pa arrived at the capital. In the year FireMale-Mouse (me-pho-byi-ba, i.e. 1276), he again returned to his monastery. ${ }^{46}$ In 1277 he held a religious assembly at Chu-mig, and rendered perfect religious service to about hundred thousand men. ${ }^{47}$ In the year Iron-Male-Dragon (lcags-pho-'brug, i. e. $12: 0),{ }^{48}$ on the twenty-second day

palace and since he had submitted a specimen of an alphabet representing a new method of learning the Mongolian writing, the king conferred upon him the supreme diploma of "ban-de progeny of Manu (sed-skyes)" (TPS, II, p. 626a). This passage in the $V D L$ is the only Tibetan source for assigning the invention of the Mongolian script to 'Phags-pa.

43 The French and English translations of this decree quoted in the $Y S$ are given by Pautheir (op. cit., pp. 12-15) and Poppe (The Mongolian Monuments,...p.5).

44 His promotion to $t i \cdot s h i h$ is supposed to have taken place just after the promulgation of the new Mongolian script. YS gives no mention of this title.

45 No account of the year of his returning to Tibet at this time is given in the sources.

46 HC states: 'In the year of Chia-shu 甲成 (1274), he was thirty-six [read forty] years old. This year was in the eleventh year of the Chih-yüan reign. The Emperor [Qubilai] dispatched an ambassador to invite him. A't the end of this year, he arrived at the capital.' TSNP also follows this. But YS states: 'In the eleventh year [of the Chih-yüan] (1274), 'Phags-pa petitioned [the throne] for sanction to return to the West (Tibet). [Qubilai] urged him to stay [at his post], however, he refused [Qubilai's request].' It is difficult to conclude when he finally returned to Tibet, because $B A$ ascribes the date for this as 1276. If we follow both the Chinese and Tibetan sources (e.g. $B A$, p. 212), 'Phags-pa returned to Tibet some time after 1270 , and came to Mongolia in 1274, again returning to Tibet in 1276. In addition, EYT gives the date of his return to Tibet as 1280 (Schmidt, p. 119), but this is evidently incorrect.

$47 B A$, p. 212 ; VDL (TPS, II, p. 627a). As to Chu-mig, Ferrari, op. cit. (p. 62) states: 'Near Snar-than is Chu-mig rin-mo of Gtsan, which formerly was reckoned in the series of the great Bka'-gdams-pa monasteries; it is the place where 'Phags-pa Rin-po-che assembled a great council. But nowadays it is a village of laymen.'

48 Only the YS gives the year of his death as the sixteenth year of Chih-yüan reign (1279). Other Chinese sources accord with the Tibetan sources. 
of the eleventh month, ${ }^{49}$ 'Phags-pa passed away aged forty-six ${ }^{50}$ in the Lha-khań bla-brań. ${ }^{51}$

Qubilai Qan, being informed of his death, was deeply grieved, providing his burial expenses and granting him a posthumous title. ${ }^{52}$ Qubilai also built a great stuppa dedicated to 'Phags-pa in the capital to enshrine his relics. ${ }^{53}$

During the Chih-chih 至治 reign (1321-3), Gegen Qan issued an Imperial edict that shrines should be dedicated to 'Phags-pa in each district and prefecture. In the first year of the T'ai-ting 泰定 reign (1324), Yesüntemur Qan further commanded that eleven portraits of 'Phags-pa should be distributed to each province in his honour. ${ }^{54}$

49 See $H C$ and TSNP.

$50 H C$ naturally gives the age of his death as forty-two. See n. 27.

51 See VDL (TPS, II. p. 627a).

52 His posthumous title is “皇天之下, 一人之上, 開教宣交, 輔治大聖, 至德湆覺, 眞智 佑國, 如意大筤法王, 西天佛子, 大元帝師, [旺弹怛 $H C$ ] 八思巴' $(Y S)$. This seems to correspond to the title in $V D L$ (TPS, II, p. 627a): 'divine son (Devaputra) of India below the sky and upon the earth, inventor of the alphabet, incarnated Buddha, maintainer of the kingdom's prosperity, source of rhetoric, Pandita 'Phags. pa, master of the Emperor.' According to FLT, fasc. 22 (Taisho, XLIX, 732c, lines 12-5), Ying-tsung 英宗 (Gegen Qan) granted 'Phags-pa this posthumous title. Cho-keng-lu 輟耕錄 by T'ao Tsung-i 陶宗儀 also mentions this title (Ch'in-tai Pishu 津逮浇書 ed. vol. 12, p. 17a). Besides, the TSNP gives his sacred name as Hui-ch'uang hsien chi-hsiang 惠幢賢吉样, which consists of 慧幢 (惠 is supposed by later scholars to be a mistransliteration of 慧 because of its identical sound) corresponding to the Skt. mati-dhvaja (mati='intelligence'; dhvaja='a banner, flag, standard'), 堅 corresponding to the Skt. pantita ('wise man') and 吉祥 corresponding to the Skt. $s r \bar{z}$ and Tib. dpal ('holy, glorious'). In the EYT, 'Phagspa's name appears as Mati Dhuvajwa which exactly corresponds to the Skt. matidhvaja. P. Ratchnevsky gives 'Phags-pa's sacred name as Blo-gros rgyal-mtshan dpal bzañ-po (Skt. Ārya Matidhvaja śr̈̈bhadra) ('Die mongolischen Grosskhane und die buddhistische Kirche'. Asiatica. Festschrift für Friedrich Weller zum 65. Geburtstag, p. 492, n. 29). In the Tsao-hsiang-liang-tu-ching yin 造像量度經引 (='Introduction to the Buddha-pratima-lakșana') (cf. Taisho, No. 1419, XXI, p. 939a), Gombojab (Tib. Mgon-po skyabs) (1690-1750?) gives 'Phags-pa's name as Lo-chui-chien-ts'an 洛追建燃 which is supposed to be Chinese transcription of his Tibetan name Blo-gros rgyal-mtshan.

$53 \quad H C$ and $T S N P$.

54 YS. In addition, Ferrari (op., cit. p. 64, cf. pp. 150-1) states: 'In its (Gzi-thog Bla-brañ) lower part there is the universe-conquering (khams-gsum-zil-gnon) chair of 'Phags-pa Rin-po-che. 
The following books are believed to have been written by 'Phags-pa.

(1) Chang-so-chih lun 彰所知满, 2 vols. (Taishō, No. 1645)

(2) Ken-pen-shuo i-ch'ieh yu-pu ch'u-chia-shou-chin yüan-chieh-mo $i$-fan 根本說一场有部出家授近国羯磨儀範, 1 vol. (Taishō,No. 1904)

(3) Ken-pen-shuo i-ch'ieh yu-pu pi-ch'u hsi-hsüeh lüeh-fa 根本說一 切有部苾努習學略法, 1 vol. (Taisho, No. 1905)

The Tibetan texts of his complete works will appear in the near future ${ }^{55}$

55 The Complete Works of Chos rgyal 'Phags-pa (=The Complete Works of the Great Masters of the Sa Skya Sect of the Tibetan Buddhism, vols. 6, 7) (Tokyo: The Tōyō Bunko, 1968-). 


\section{II \\ THE 'PHAGS-PA ALPHABET}

\section{§ 1. The Invention of the 'Phags-pa Script}

According to the $Y S$, there were forty-one letters in the 'Phags-pa alphabet when it was invented by Bla-ma 'Phags-pa in 1269 . In both the $Y S L P$ and HYS the editors give commentaries quoted from the SSHY written by $T$ 'ao Tsung-i, which follows almost identically the description in the FSK written by Sheng Hsi-ming in the Yüan dynasty. The FSK states :

There are forty-one letters : 1 No. $1 . \pi$ ，葛；2. 秛，渴；3. 百，

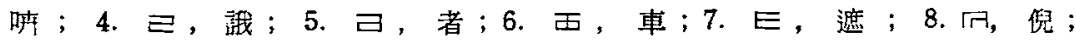

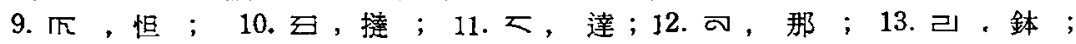

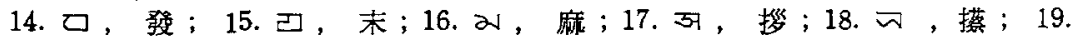

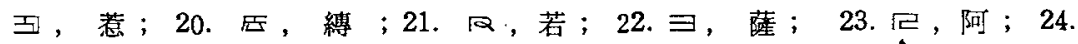

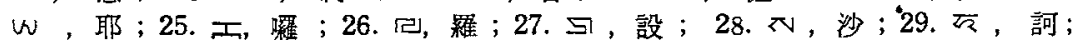

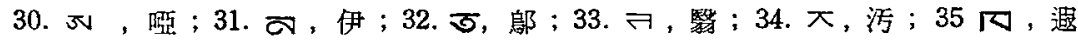

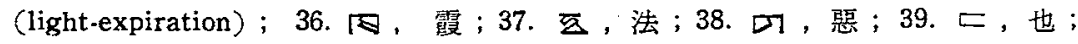
40. $\triangle$, 骨 ; 41. $上$, 耶, (light-expiration).

The above letters are represented by their Chinese phonetic equivalents. They are pronounced with an open-mouth. ${ }^{2}$ Among them three letters, Nos. $25,35$.

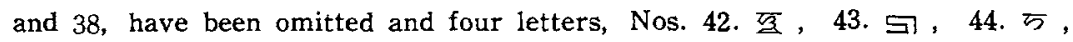
and 45. $W$, have been added instead. The spelling is mostly based upon the Sanskrit rules. ${ }^{3}$

In the FSK, the Chinese transcription of the initial consonants of 'Phagspa script follows that in the Ching-yu T'ien-chu Tzu-yüan 景新天䇥字源

1 According to the FSK (Ssu-k'u Ch'üan-shu 四莗全書 ed.) and SSHY, 'there are forty-three letters' notwithstanding that the actual number of letters is forty-one. But the FSK (Ssu-pu Ts 'ung-k'an hsü-pien 四部莎刊續編 ed.) and YSLP based on the $S S H Y$ mention forty-one letters, the sameras the description in the $Y S$, so I follow the FSK (Ssu-pu Ts'ung-k'an hsü-pien ed.) and the table of the SSHY.

2 This passage means that to the pronunciation of each letter the vowel $a$ must be attached because the letter $a$ is not included, in accordance with the Tibetan and Sanskrit rules. See Krueger's 'Supplementary Remarks' added to Poppe's The Mongolian Monuments..., p. 146.

3 This quotation from the SSHY is also translated into English in Poppe, ibid., p. 14. Clauson also gives a translation of this passage in the FSK ('The $h$ 'P. ags-pa alphabet', pp. 302-3). Pauthier translates this passage in the SSHY into French ('De l'alphabet de Pa'-sse-pa,...', pp. 24-31). 
(abbr. CTT) which was written by Wei-ching 惟淨 in 1035.4 This transcription of the Sanskrit alphabet seen in the CTT had itself been derived from the traditional way of transcribing Sanskrit since Fa-hsien 法顯, T'an-wu-ch'an 量無㙨 (Skt. Dharmakșema?), etc. ${ }^{5}$ Since the T'ang dyrasty, however, Chinese transcription had been partly influenced by the northwestern dialects of China, in which certain phonetic changes occurred at that time. Therefore, characters which are used in the CTT are mostly identical with transcriptions used by Pu-k'ung 不空 (Skt. Amoghavajra) and his followers. ${ }^{6}$

\footnotetext{
4 According to R.H. van Gulik, Siddham,... (=Sarasvati-Vihara Series, 36), pp. 91-2, 'this book, in seven chapters, was translated from the Sanskrit by an Indian monk called Dharmarakșa, and the text was edited by the Chinese monk Weiching.' But it is still doubtful whether Dharmarkșa really translated this book from Sanskrit or not. Moreover, the most recent study indicates that Dharmaraikșa (Chin. Fa-hu 法護) should be corrected to Dharmapāla (see Jan Yün-hua, 'Buddhist relations between India and Sung China', History of Religions (Chicago), VI, 1 (1966), pp. 39-41). Therefore, I do not follow van Gulik, but simply state the editor or compiler of the CTT to be Wei-ching. This text was published in a facsimile edition by Lo Chen-yü in 1916 based on the text held in the Tōkyō Imperial Museum.
}

5 For example, Wen-tzu-p'in 文字品 in the Ta-pan-ni-huan-ching 大般泥洹經(Skt. Mahāparinirvānasūtra) (Taishō, No. 376), tr. (A. D. 417) by Fa-hsien 法顯; $J u$-lai-hsing-p'in 如來性品 in the Ta-pan-nieh-p'an-ching 大般涅槃經 (Skt. Maha parinirvānasūtra?) (Taishō, No. 7), tr.(414-21) by T' an-wu-ch' an 爱哭鐵 (Skt. Dharmakșema?),; Tzu-mu-p' in 字母品 in the Wen-shu-shih-li-wen-ching 交殊師利 問經 (Skt. Mañjuśrizpariprcchā) (Taishō, No. 468) tr. (518) by Seng-chia-p' o-lo 僧伽婆羅 (Skt. Samghabhara ?), Fo-pen-hsing-chi-ching 佛本行集經 (Skt. Abhinișkramanasütra?) (Taisho, No. 190), tr. (589-92) by She-na-chuieh-to 閣那崛多 (Skt. Jñănagupta); Shih-shu-p' in 示書品 in the Fang-kuang-ta-chuang-yen-ching 方廣大莊噘經 (Skt. Lalitavistara) (Taishō, No.187), tr. (685) by Ti-p' o-ho-lo 地 婆訶羅 (Skt. Divākara); Hsi-t' an Tzu-chi 悉是字記 (Taishō ${ }_{3}$ No. 2132) (780-804) by Chih-kuang 智廣. For further detail see Lo Ch'ang-p'ei, 'Fan-wen o-yin wumu te Tsang-Han tui-yin yen-chiu', AS, III, 2 (1931), pp. 263-76. However, it is still doubtful whether the Chinese Buddhist texts were directly translated from Sanskrit or not. It is quite possible that the original Sanskrit Buddhist texts were first translated into the Tocharian, Sogdian, or other languages, and then translated into Chinese. Here, I simply follow the alphabetical tables of Sanskrit in the Chinese Buddhist texts regardless of the possibility of the existence of intermediary languages. This is because the rules for transcribing Sanskrit in the Chinese Buddhist texts had already been fixed, and it is impossible to estimate the influence of intermediary languages. See T. Haneda, 'Kanyaku no Butten ni tsuite', repr. in Haneda Hakushi Shigaku Ronbunshï, II, pp. 348-57.

6 For example, Yï-chia-chin-kang-ting-ching Shi-tzu-mu-p' in 瑜伽金网打頁桱䆁字母品 
The forty-one letters in the FSK are arranged in Table 1 with the hypothetical transcriptions given by various scholars.

Nos. 1-41 in this table are mentioned both in the FSK and SSHY, and they are supposed to be the letters invented by Bla-ma 'Phags-pa. Nos. 25, 35 and 38 were omitted later and Nos. 42-45 were added instead as a result of the needs of transcribing.

It should not be surprising that there are five letters (Nos. 42-45) in the MKTY, which the FSK mentions. It is supposed that these five letters were added by Chu Tsung-wen, a compiler of the $M K T Y$, as a result of transcribing the Chinese (non-Mandarin) sounds.

After the invention of the 'Phags-pa script, the Mongolian government tried to enforce the use of this new script; to establish Meng-ku Tzu-hsüeh 蒙古字學 (schools for the Mongolian script) in each province, ${ }^{7}$ to write edicts, epigraphs, codes, and rhyme dictionaries in the 'Phagspa script. ${ }^{8}$ It remained in general use throughout the Yüan dynasty ; ${ }^{9}$ but, after the Yüan dynasty fell it was no longer used and disappeared. Nevertheless, the 'Phags-pa script has occasionally continued in use as seal-script by the Tibetans, by whom it is known as one of the Hor-yig.

(Skt. ?) (Taishō, No. 880) and Wen-shu-wen-ching Tzu-mu-p' in 交殊問經字母 品 (Taisho, No. 469), both tr. (771) by Pu.k'ung 不空 (Skt. Amoghavajra); Pien Wen-tzu Kung-te chi Ch'u-sheng Tz'u-ti-pien 辨交字功德及出生次第筹 in the $I$ ch'ieh-ching Yin-i-hih-Sa-pan-nieh-p' an-ching一切經晋義釋大般涅然經 (Taishō, No.

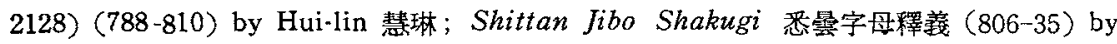
Kükai 空海; CTT by Wei-ching. For further details, also see Lo Ch'ang-p'ei, ibid., especially his 'Comparative table of Chinese characters used in transcribing the forty-nine letters of the Sanskrit alphabet in sutras'.

7 See the FLT (Taisho, XLIX, p. 705c), which states that the establishment of Mongolian schools took place in the seventh year lof the Chih-yüan reign (1270), probably after the eleventh month of this year.

8 On the enforcement of the 'Phags-pa script in the Yuian dynasty, see Lo Ch'angp'ei and Ts'ai Mei-piao, PSPT, pp. 1-30. On the rhyme dictionaries in the 'Phags-pa script, see Cheng Tsai-fa, MKTY ken ken Pa-ssu-pa-tzu yu-kuan te yün-shu, pp. 15-77. According to Cheng Tsai-fa, at least the two rhyme dictionaries, the Meng-ku Yün-lizeh 蒙古韻略 and Meng-ku Yün-pien 蒙古䫓編, are known to have existed before the $M K T Y$ was compiled. Also the $M K T Y$ is very likely based on these books, or is rather a revision of the Meng-ku Yün-lüeh.

- Even in the Yüan dynasty, however, the Uighur script was occasionally used in official documents. For example, see A. Mostaert and F.W. Cleaves, 'Trois docu- 


\section{\& 2. The Phonetic Value of Individual Letters}

The letters in Table 1 are divided into eleven groups mainly, in accordance with the traditional Chinese classification except groups $\mathrm{J}$ and $\mathrm{K}$, as follows, and will be discussed in this order:

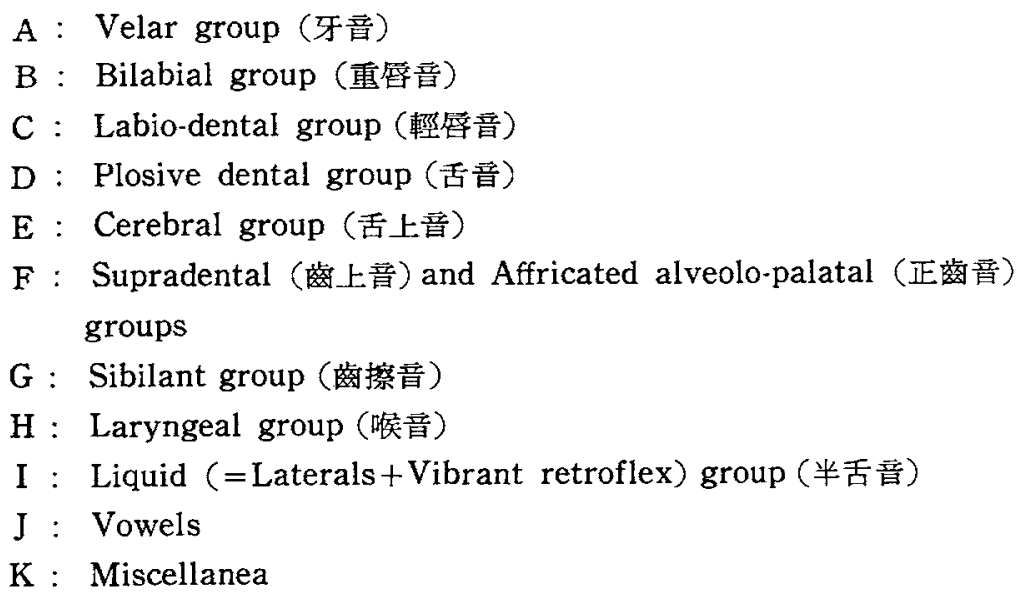

\section{A : Velar group}

The characters Nos. 1-4 refer to the Sanskrit alphabet $k a, k h a, g a$, $\dot{n} a$ respectively. In the $C T T$, or the other Chinese Buddhist texts, the character 竭 is added from the necessity of transcribing the Sanskrit gha, which does not exist in the Chinese language. ${ }^{10}$ Similarly, in the FSK no other initial group has a character for the Sanskrit aspirated voiced initials.

No. 3 is represented by the character 暁 wich has an initial $\eta^{11}$

ments mongols des archives secrètes Vaticanes', HJAS, XV (1952), pp. 419-506+ 8 plates [especially see plate II (Letter of Argun to Nicolas IV dated 1290) and plate V (Letter of öljeitü to Philippe le Bel dated 1305)].

10 Karlgren proposes that Ancient Chinese voiced initials had an aspiration, but this is still doubtful. However, the fact that no character has been used to transcribe the Sanskrit gha, dha,bha,... series cannot be cited as evidence against Karlgren's hypothesis, because in Ancient Chinese voiced initials there was phonological opposition between aspirate and non-aspirate as in Sanskrit.

11 This character gives trouble to Clauson (op. cit., p. 309, n. 1). Because 'the character used is not in Grammata Serica Recensa nor in Giles' dictionary,' he 
Table I-a.

\begin{tabular}{|c|c|c|c|c|c|c|c|c|}
\hline & No & 'Pgs. & $\begin{array}{l}\text { Tib. } \\
\text { equivalent }\end{array}$ & ESK & MKTY & $\begin{array}{l}\text { Gabelen } \\
t 2.1839\end{array}$ & ${ }_{1862}^{\text {authierp }}$ & $\begin{array}{l}\text { ragunot } \\
1930\end{array}$ \\
\hline & 1 & $\pi$ & $\eta$ & 莫 $\mathrm{k}$ & 群 g & ko & $k$ & $k$ \\
\hline & 2 & 向 & A kha & 渴 $\mathrm{k}^{\prime}$ & 溪 $k^{\prime}$ & kho & $\mathrm{kh}$ & $k^{\prime}$ \\
\hline $\mathbf{A}$ & 3 & 句 & 可 $g$ & 哇 凡 & 見 k & ko & $g$ & $g$ \\
\hline & 4 & $\rightleftharpoons$ & ᄃ $\quad$ ía & 誐 ク & 皆 & ngo & ng & \\
\hline & 13 & ᄅ & pa & 鈦 p & 前 $b$ & po & $\mathrm{p}$ & $p$ \\
\hline & 14 & 己 & \& pha & 登 $\mathrm{p}^{\mathrm{t}}$ & 滂 $\mathrm{p}^{\mathrm{t}}$ & pho & $p h, p$ & $p^{\prime}$ \\
\hline B & 15 & 己 & ba & 杰 m & 垬 $p$ & mo & $b, r$ & b \\
\hline & 16 & 21 & d $\quad \mathrm{ma}$ & 麻 m & 明 m & $\mathrm{ma}$ & m & $\mathrm{m}$ \\
\hline & 37 & 5 & - & 法 1 & 非乙。 & $\mathrm{fa}$ & ha, $f$ & - \\
\hline & 46 & $\sqrt{3}$ & - & $-\quad-$ & 敷」 & - & - & - \\
\hline c & 42 & 5 & - & $-\quad-$ & 奉 $\vee$ & - & - & - \\
\hline & 20 & 古 & wa & 縛 & 徏、 & fo & ॠŏ;ă̆,o & $\pi$ \\
\hline & 9 & $\sqrt{n}$ & ta & 怛 $t$ & 定 d & ta & $t$ & $t$ \\
\hline & 10 & $\varepsilon$ & 9 tha & 撻 & 透 t & the & th, $t$ & t \\
\hline$D$ & 11 & र & $5 \quad \mathrm{da}$ & 洋 d & 端 $\mathrm{t}$ & $\therefore$ ta & $\mathrm{d}$ & d \\
\hline & 12 & क & q $\mathrm{na}$ & 那 n & 泥 n & $\mathrm{n}$ & $\mathrm{n}$ & $n$ \\
\hline & 5 & $\Xi$ & $\mathrm{ca}$ & 都切 & 澄趽 & tche & $\operatorname{tch}$ & $\check{c}$ \\
\hline & 6 & 王 & $\Phi$ cha & 車袖 & 琉 & tchha & $\operatorname{tch}$. & č' \\
\hline$E$ & 7 & $E$ & E ja & 遮 & 知 & tche & $d j$ & క̆ \\
\hline & 8 & $\sqrt{7}$ & $3 \tilde{\mathrm{n}} \mathrm{a}$ & 倪 y & 艮 $\tilde{\mathrm{n}}$ & $n i$ & $\widetilde{\mathrm{B}} \mathrm{n}$ & - \\
\hline & (5) & - & $-\quad-$ & - & 床 & - & - & - \\
\hline & (6) & - & - & - & 穿探 & - & - & - \\
\hline F & (7) & - & - & - & 照垎 & - & - & - \\
\hline & 27 & క & q & 設 & 審 & che & ch & รั \\
\hline & 43 & 与 & - & $-\quad-$ & 禪 ₹ & - & - & - \\
\hline
\end{tabular}




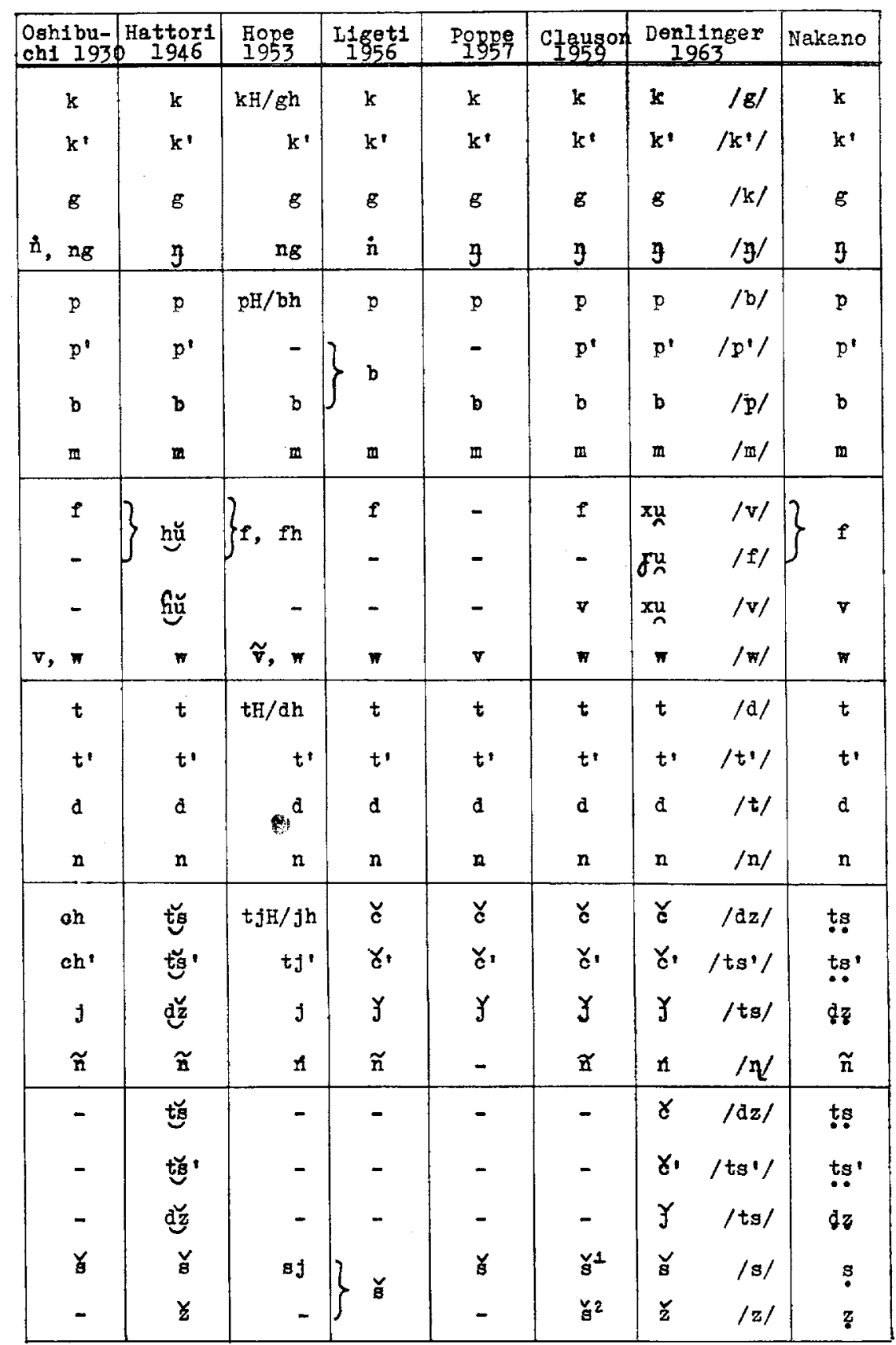


Table I-b

\begin{tabular}{|c|c|c|c|c|c|c|c|c|}
\hline & No. & 'Pgs. & \begin{tabular}{c|} 
Tib. \\
equival ent
\end{tabular} & FSK & MKTY & $\begin{array}{l}\text { caselen- } \\
\mathrm{tz}_{2}\end{array}$ & $\begin{array}{l}\text { Pauthier } \\
1862\end{array}$ & Dragunot \\
\hline & 17 & 37 & $\begin{array}{ll}\boldsymbol{z} & \text { tsa }\end{array}$ & 搩 ts & 從 dz & tsa & ds & ts \\
\hline & 18 & ज & Б tsha & 攃地' & 清 $t^{\prime}$ & ths & ths & $t_{s}$ \\
\hline$G$ & 19 & 弱 & $E \quad d z a$ & 惹 : & 精 ts & je & ts & $d \mathbf{s}$ \\
\hline & 28 & 지 & s $\mathrm{sa}$ & 沙 \& & 心 & cha & sz, s & $\mathbf{s}$ \\
\hline & 22 & $\exists$ & $z a$ & 薩 s & 邪 $=$ & sa & $s, z$ & $z$ \\
\hline \multirow{8}{*}{$\mathrm{H}$} & 29 & $\sqrt{2}$ & 5 ha & 訶 $h$ & 曉 h & ho & ih,f,e & h \\
\hline & 44 & 反 & - & $-\quad-$ & 闸 & - & - & - \\
\hline & 35 & ח & - & 起 & $-\quad-$ & hia & bôे & - \\
\hline & 36 & $\sqrt{8}$ & - & 霞 h & 匣(合) f & hia & ' $h$ & $f$ \\
\hline & 23 & e & a & 阿 • & 景 & ngo & $h, 1 h$ & - \\
\hline & 30 & ऊ & w & 吸荫 & 喻(魚)j & ou & $\hat{a}$ iñit. & e \\
\hline & 24 & $w$ & w $y a$ & 㠷 j & 喻 j & ye & $y, a$ & $j$ \\
\hline & 45 & $w$ & - & $-\quad-$ & 影(X) y & - & - & - \\
\hline \multirow[b]{2}{*}{ I } & 26 & 己 & $2 a$ & 羅 I & 來 I & 10 & 1 & 1 \\
\hline & 21 & $\alpha$ & $9 \quad 2 a$ & 若 的 & 日 $\dot{r}$ & jo & $j$ & $\check{\mathbf{z}}$ \\
\hline \multirow{7}{*}{$\mathrm{J}$} & 31 & क & 1 & 伊 - & & y & $\hat{1}$ init. & $i$ \\
\hline & 32 & চ & $u$ & 鄔 - & $-\quad-$ & u & oû init. & u \\
\hline & 33 & $\nabla$ & & 毉 - & & ye & $\hat{i}, i$ & 8 \\
\hline & 34 & 大 & $\checkmark$ & 活 - & & 0 & ou & 0 \\
\hline & 39 & $ᄃ$ & - & 也 - & - & e & e & e \\
\hline & 40 & $\Delta$ & $\Delta \quad(w)$ & 咼 - & - & $u, n$ & ou, oua & $\stackrel{u}{n}$ \\
\hline & 41 & $E$ & $<$ (ya) & 耶 - & - & - & $y \hat{e}, e$ & - \\
\hline \multirow{2}{*}{ K } & 25 & $I$ & $=\quad I$ & 囉 1 & & $10(r o)$ & $\mathbf{r}$ & - \\
\hline & 38 & पा & - & 惡 - & - & ngo & 10 & - \\
\hline
\end{tabular}




\begin{tabular}{|c|c|c|c|c|c|c|c|}
\hline $\begin{array}{c}\text { Pshibuc } \\
1930\end{array}$ & $\begin{array}{l}1 \text { Hattori } \\
1946\end{array}$ & $\begin{array}{l}\text { Hope } \\
\text { I953 }\end{array}$ & $\begin{array}{c}\text { Iigett } \\
1956 \\
\end{array}$ & $\begin{array}{r}\text { Poppe } \\
1957 \\
\end{array}$ & $\begin{array}{l}\text { Clauson } \\
1959\end{array}$ & $\begin{array}{l}\text { Denlinger } \\
1963\end{array}$ & Nakano \\
\hline $\mathrm{ds}$ & ts & $\mathrm{tzH} / \mathrm{zh}$ & c & \} & ts & c $/ \mathrm{dz} /$ & ts \\
\hline$t s^{\prime}$ & $\operatorname{tg}{ }^{\circ}$ & $t z$ & $c^{\prime}$ & & $t s^{\prime}$ & c' /ts'/ & $t_{s}$ ' \\
\hline ts & $d z$ & $\mathrm{dz}$ & $c, 3$ & $j$ & $\mathrm{~d} z$ & $j / t s /$ & $\mathrm{dz}$ \\
\hline $\mathbf{s}$ & $\mathbf{s}$ & $\mathbf{s}$ & $\mathbf{s}$ & s & $\mathbf{s}$ & $/ s /$ & 8 \\
\hline $\mathbf{z}$ & $\mathbf{z}$ & szh & $z$ & $z$ & $\mathbf{z}$ & $\mid z /$ & $\mathbf{z}$ \\
\hline $\mathrm{h}$ & $\mathrm{h}$ & $x$ & & h & $h^{1}$ & $\underline{n} \quad / x i /$ & $\mathrm{h}$ \\
\hline - & f & - & & - & $h^{2}$ & $\mathrm{~h} / \gamma^{i} /$ & G \\
\hline - & - & $(k x)$ & - & $q$ & $g(f)$ & $f$ & - \\
\hline$h^{\prime}$ & $\gamma$ & $h(\gamma)$ & $f$ & $\delta$ & $x(x)$ & $x \quad / f /$ & $\mathcal{J}$ \\
\hline${ }^{t} h$ & e & clear & • & - & $\underline{h}$ & - $\quad / \tau /$ & • \\
\hline a & , & $\begin{array}{l}\text { mudd } \\
\text { pitch }\end{array}$ & "u & a & $+(a)$ & $1 \phi 1$ & $y$ \\
\hline$y$ & $j$ & $\mathrm{y}$ & & $y$ & $y^{1}$ & $y \quad\{/ \phi i /$ & $j$ \\
\hline - & $\mathrm{y}$ & - & & - & $y^{2}$ & $\mathrm{y} \quad\left\{\begin{array}{l}|\phi i| \\
|x|\end{array}\right.$ & $\cdot j$ \\
\hline 1 & 1 & 1 & 1 & 1 & 1 & $/ 1 /$ & 1 \\
\hline $\mathrm{zh}$ & $z$ & $2 \mathrm{~h}$ & $\dot{\mathbf{z}}$ & $\check{z}$ & $\check{\mathbf{z}}$ & $\check{z}\{|\check{z}|$ & $\grave{r}$ \\
\hline 1 & $i$ & 1 & $i$ & $i$ & $i$ & $/ i /$ & $i$ \\
\hline$u$ & u & u & ' $u$ & $u$ & $u$ & $/ \mathrm{u} /$ & $u$ \\
\hline e & $\varepsilon$ & $e(i a)$ & e & $\dot{e}$ & e & $y+$ (a) /ia/ & $\varepsilon$ \\
\hline 0 & o & $o$ (ua) & $0, \hat{o}$ & o & 0 & 101 & 0 \\
\hline e & e & $\ddot{a}$ & .. & e & e & $i+(a) / i a /$ & $e$ \\
\hline w & $\breve{\mathrm{u}}$ & $v$ & $u_{n}$ & $\underline{n}$ & $-w$ & $u_{+}$(a)/ua/ & $\breve{u}$ \\
\hline ia & $Y(a)$ & $\mathrm{y}$ & ia & $\mathrm{y}$ & $-\mathrm{y}$ & $y+(a) / i a /$ & I \\
\hline$r$ & - & - & - & $r$ & $r$ & $\mathbf{r}$ & $r$ \\
\hline- & - & - & - & - & (?) & - & - \\
\hline
\end{tabular}


although the Tibetan and Sanskrit equivalents of this letter have a phonetic value $g$. A similar kind of alternation between $y$ and $g$ can be seen in Nos. 11, 15 and 19, which are represented by $d, b$, and $d z$ respectively, not only in the $F S K$ and $C T T$ but also in other Chinese Buddhist texts since the T'ang dynasty, as Table 2 shows:

Table 2

\begin{tabular}{cll}
\hline Skt. & \multicolumn{2}{c}{ Chin. } \\
& Old trsc. & \multicolumn{1}{c}{ Buddhist texts } \\
New trsc.
\end{tabular}

Conversely, we find other examples which show Chinese nasals transcribed by the Tibetan or Uighur plosives as Table 3 shows :

Table 3

\begin{tabular}{|c|c|c|}
\hline $\mathrm{AC}$ & Tibetan trsc. & Uighur trsc. \\
\hline$m-$ & $\begin{array}{l}\text { 妙 'byehu，莫 'bag [S]； } \\
\text { 磨 'ba, 窭 'bi, 微 'byi [C1]; } \\
\text { 漠 'bag, 門 'bun [H] }\end{array}$ & $\begin{array}{l}\text { 摩 } b a, \text { 昧 } b a i, \\
\text { 萬 ban, 戊 bou, } \\
\text { 默 bag }[\mathrm{C} 2]\end{array}$ \\
\hline$n-$ & $\begin{array}{l}\text { 農 'don', 念 'dyam (or nyam }{ }^{12} \text { ) } \\
{[\mathrm{S}] \text {;那 ' } d a \text { ', 納 'dab [C1] }}\end{array}$ & no example \\
\hline$\eta^{-}$ & $\begin{array}{l}\text { 五 'gu (or 'go), 礙 'ge [S]; } \\
\text { 業 'geb, 議 'gi [C1]; 鴈 'gan, } \\
\text { 蓺 'ge'i [H] }\end{array}$ & $\begin{array}{l}\text { 元 } g \ddot{o} n, \text { 彥 } g e n, \\
\text { 危 } g \ddot{u}, \text { 義 } g i[\mathrm{C} 2]\end{array}$ \\
\hline$n \dot{n z}-$ & 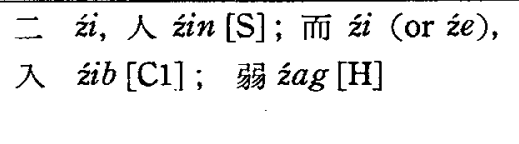 & $\begin{array}{l}\text { 壬 } n \check{z} i m \text { (or šim) } \\
\text { 1 žin, 如 } \check{z} \ddot{u}, \\
\text { 日 žir [C 2] }\end{array}$ \\
\hline
\end{tabular}

assumes that the phonetic value of this character is $x j w e i$ 'on the assumption that the "mouth" radical is not part of the character, but a sound modifier.' However, it is very easy to find this character in any Chinese dictionary by the fan-ch'ieh system; i.e. 牙葛切, 語訐切, and 許費切. The CTT annotates 五割切 for the Sanskrit $g a$ which is equivalent to No. 3 , therefore in this case this character should have an initial. $y$

12 It is believed that the characters which have the nasal finals $-n,-n,-\eta$ have 
Abbreviations in this table are follows:

$[\mathrm{S}]=\mathrm{W}$. Simon, 'A note on Chinese texts in Tibetan transcription', BSOAS, XXI (1958), pp. 334-43.

$[\mathrm{H}]=\mathrm{T}$. Haneda, 'Kan-Ban taion Senjimon no dankan', Haneda Hakushi Shigaku Ronbunshizi, II, pp. 396-419.

[C1] = B. Csongor, 'Some Chinese texts in Tibetan script from Tun-huang', $A O H$, X (1960), pp. 97-140.

[ C2 ] = Csongor, 'Chinese in the Uighur script of the T'ang-period', $A O H$, II (1952), pp. 73-121.

The above examples suggest that the Chinese transcription of Sanskrit and the Tibetan and Uighur transcriptions of Chinese have been influenced by the denasalisation which occurred in the northwestern dialects in the T'ang period. ${ }^{13}$ This denasalisation can be theoretically deduced as follows :

$$
\begin{aligned}
& m>m b>b \\
& n>n d>d \\
& \eta>n g>g \\
& n>n \dot{z}>\dot{z} \text { (or } \dot{r})
\end{aligned}
$$

According to this assumption, it is not surprising that the Sanskrit $g$, $d, b, j$ were represented by the Chinese $\eta, n, m, n \dot{z}$ respectively, and that the Chinese $m, n, \eta, n$ were transcribed as $b, d, g$, $z$ by the Tibet. ans and Uighurs.

This phenomenon, however, did not continue in the succeeding Sung and Yüan periods, because the capital returned to the Middle Plain after the fall of the T'ang dynasty. ${ }^{14}$ However, the Chinese transcription of

never undergone the denasalisation. Examples of this can be seen in the Tibetan and Uighur transcriptions and in the Kan-on version of Sino-Japanese. But this rule is not always applicable, as seen in two variant transcriptions for the character 念 and the Kan-on version used in the Tendai sect (Tendai Kan-on 天臺漢晋), For further details, see H. Arisaka, 'Mei, nei no tagui wa hatashite Kan-on narazaruka ?", Kokugo On'inshi no Kenkyū (rev. ed.), pp. 369-74.

13 On the denasalisation, see $H$. Maspero, 'Le dialecte de Tch'ang-ngan sous les T'ang', BEFEO, XX, 2(1920), pp. 1-124, especially pp. 29-36; T. Ogawa, ' $N i$ to erh oyobi jih-mu no seiritsu', $G K, 24$ (1953), pp. 7-11; S. Mizutani, 'Tōdai ni okeru Chūgokugo gotō bion no denasalization shinkō katei', TYGH, XXXIX, 4 (1957), pp. 1-31.

14 In the Tó-on version of Sino-Japanese which was influenced by some Middle Plain dialects of the Sung and Yüan periods, these phonemes have no longer been 
Sanskrit apparently still followed the pattern fixed in the T'ang time as seen in the CTT. Sheng Hsi-ming, the author of the FSK, also followed the CTT.

The phonetic values of Nos. 1-4 are, therefore, $k, k^{\prime}, g, \eta$ respectively, in accordance with the Chinese system of phonology.

On the other hand, this alternation between nasals and plosives in the $C T T, F S K$, and other Chinese Buddhist texts suggests that the phenomenon of alternation between voiced and voiceless initials of Chinese in the 'Phags-pa script does not occur through the aspiration of voiced initials as Karlgren explained but through the difference of phonological opposition between Chinese and Mongolian. This problem will be discussed in further details in the next chapter.

\section{B : Bilabial group}

In this group the phoneme $p^{\prime}$ does not appear in Dragunov's, Hope's, and Poppe's materials, because the phoneme $p^{\prime}$ has never existed in Mongolian. The $P C H$, according to Ligeti, ${ }^{15}$ includes many letters denoting $p, p$, and $b$, which are considerably confused in this book. Even in the $F S K$, No. 13 representing $p$ is given mistakenly as $\varpi$ which is exactly the same as $b$. Also, No. 14 has a shape which can be easily confused with No. 15. Comparing this with the Tibetan equivalent of No. 15, No. 14 might have had a shape somewhat similar to the Tibetan 4 as seen in some modern Tibetan seals. ${ }^{16}$ However, the Mongolians have never used this No. 14, and its lack of use might have increased the possibility for it to have become confused with No. 15.

\section{C: Labio-dental group}

It is supposed that Bla-ma 'Phags-pa invented only Nos. 37 and 20 in

influenced by denasalisation. For further details, see Arisaka, 'Fugin no Tẽ.on ni han'ei shita Kamakura jidai no on'in jōtoi', Kokugo On'inshi no Kenkyă, pp. $185-220$.

15 'Le Po kia sing en écriture 'phags-pa', p. 15, n. 49.

16

In Das' plate, Francke's table ('Note on the Dalai Lama's seal...', pp. 1211- 
this group. As far as the phoneme $f$ is concerned, he may well have invented No. 37 , which has a compound shape consisting of a combination of Nos. $29 h$ and $40 \tilde{u}$, by analogy with the fact that the phoneme $h$, when accompanied by a ho-k'ou 合口 (rounded-mouth) medial $\breve{u}$, can easily become an expiratory $f$. Originally, as shown by Pelliot and Aalto, the phoneme $f$ did not exist in the Tibetan and Mongolian languages. ${ }^{17}$ In Chinese, the phoneme $f$ came into existence in the Northern Sung time, ${ }^{18}$ and the earliest meterial indicating this fact is the Huangchi Ching-shih T'ien-sheng Ti-yin T'u 皇極經世天聲地豆圖 (abbr. HCCS), which is a simple rhyme table written by Shao Yung 邵雍. ${ }^{19}$ In this rhyme table the four bilabial initials pang-菩, p'ang-滂, ping-並 and ming-明 initials which had the third-degree final and the medial $u$ in Ancient Chinese might have changed to the labio-dental initials fei- 非, fu- 數, feng- 奉 and wei- 微 initials. Theoretically speaking, this change can be shown by the following schema:

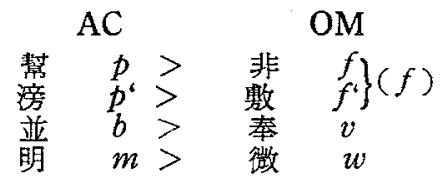

In fact, however, the phoneme $f^{\prime}$ ought not to exist because the phoneme $f$ is always accompanied by an aspiration, so this schema should be

12) and the Rgya-dkar-nag..., the variant shapes of No. 14 can be seen as $E$, ㄹ, 퍼, $冗$, etc.

17 Pelliot, 'Les mots à $h$ initiale, aujourd'hui amuie dans le mongol des XIII et XIVe siècles', $J A$, CCVI, 2 (1925), pp. 193-263; Aalto, 'On the Altaic initial p-', CAJ, I (1955), pp. 5-16.

18 Perhaps Ch'ien Ta-hsin 錢大所 is the first scholar to mention the derivation of labio-dentals from bilabials. See 'Ku wu ch'ing-ch'en-yin 古無輕唇音', Shih-chia-

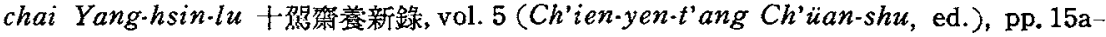
27 a.

19 On this rhyme table, see Chou Tsu-mo, 'Sung-tai Pien-Lo yü-yin k'ao', FJHC, XII, 1/2 (1943), pp. 221-85; Lu Chih-wei, 'Chi Shao Yung HCCS te t'ien-sheng ti-yin', YCHP, XXXI (1946), pp. 71-80; Li Jung, 'HCCS chieh', Ch'ieh-yün Yin. hsi (Peking, 1952), pp. 165-74; Chao Yin-t'ang, Teng-yïn Yüan-liu (Shanghai; 1957), pp. 84-92; A. Tōdō, Chügokugo On'inron (Tokyo, 1957), pp. 115-18 and 'Development of Mandarin from 14c. to 19c.', $A A$, VI (1964), pp. 31-40. 
corrected to $(f)$. In the Mandarin-speaking area the phoneme $v$ has never existed because the voiced initials have been assimilated to either voiceless non-aspirated or voiceless aspirated initials depending on their tones, although in the non-Mandarin area the voiced initials have been partly retained. From this fact, it is not difflcult to suppose that Blama 'Phags-pa invented only two letters denoting the phonemes $f$ and $w$ to transcribe the sounds of the Mandarin-speaking area. Nevertheless, appearance of another two letters, Nos. 42 and 46 in the MKTY, is probably due to the fact that No. 42 was needed to represent the southern dialects which retained the voiced initials, and No. 46 was fitted in by Chu Tsung-wen's adherence to the traditional concepts of Chinese phonology. Although Denlinger states: 'The distinction between $f$ and $v$ is probably an archaizing distinction with no basis in the spoken language of the time,'20 Chu Tsung-wen's archaising is, as mentioned above, limited only to No. 46. Denlinger mistakenly supposes it also affects No. 42 , but this conflicts with what we know of the phonology of Middle Chinese. He also fails to distinguish the letter shapes of Nos. 37, 46, and 42. He maintains that Nos. 37 and 42 are apparently identical, but it is very difficult to distinguish No. 46 from Nos. 37 and 42 in any original material. However, a study of the $M K T Y$ reveals clear distinctions in the use of Nos. 37, 46, and 42, and thus Denlinger is somewhat wide of the mark when he transliterates $x u$ for Nos. 37,42 and $\gamma u$ for No. 46 and also gives the Chinese phonemes $v$ for Nos. 37, 42 and $f$ for No. 46 . Nos. 37 and 46 should be transcribed $f$, as Clauson did, or $h \breve{l}$, as Hattori did, and No. 42 should be transcribed as $v$ (or hă in Hattori). (See Table 1.)

\section{D : Plosive dental group}

According to the $C T T$, the Chinese equivalent of the Sanskrit $d a$ is 挣, which also illustrates alternation by the denasalisation. The character 達 in the FSK is used for the Sanskrit dha in the CTT and other Chinese Buddhist texts. Nevertheless, this mistake by Sheng Hsi-ming suggests that his spoken language had not undergone the denasalisation

20 'Chinese in hP'ags-pa script', MS, XXII (1963), pp. 419-20. 
of the northwestern dialects in the T'ang period. He might simply have followed his own spoken language while on the other hand adopting the traditional usage of characters for Sanskrit. Therefore, from the viewpoint of traditional Chinese Buddhist texts, Sheng Hsi-ming's 達 is a mistake, but from the viewpoint of Chinese as spoken in the Middle Plain, this transcription is of course correct.

\section{E: Cerebral group \\ F : Supradental and Affricated alveolo-palatal groups}

A full account of the cerebral group is given by Lo Ch'ang-p'ei. ${ }^{21}$ This group has been assimilated to the group $F$ since the eleventh century. ${ }^{22}$ In the Mandarin-speaking area the phonetic changes of the groups $E$ and $F$ can be shown as follows;

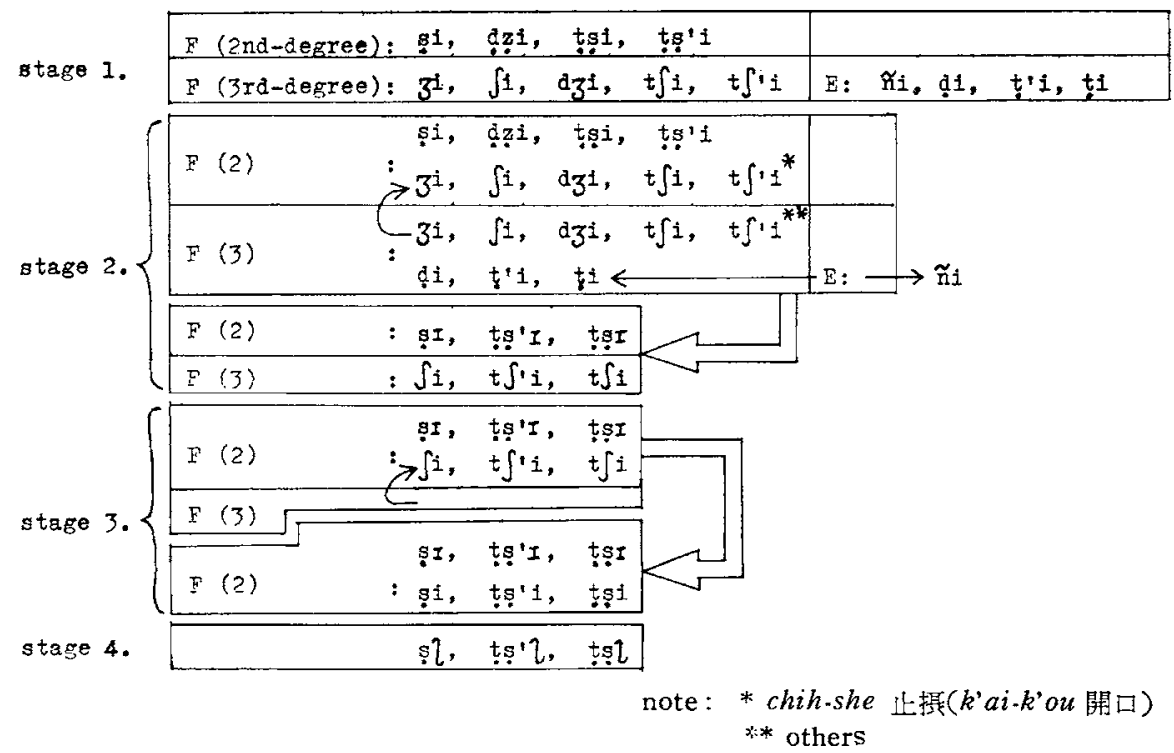

21 'Chih, ch'e, ch'eng, niang yin-chih k'ao', AS, III, 1 (1931), pp. 121-57.

22 The earliest indication of this change can be seen in the HCCS. In this rhyme table, affricated alveolo-palatals have been assimilated to the supradental group. However, this table is too simple to illustrate fully the structure of the sound system. 
In these schema, stages 1-4 signify Ancient Chinese, Old Mandarin (1117 C.), Middle Mandarin (17 C.), ${ }^{23}$ and Modern Mandarin respectively. The CYYY and MKTY are the products of stage 2, but it must be noted that in these rhyme dictionaries there is no phonetic distinction between $s, t s^{\prime}, t s$ and $\int, t f^{\prime}, t \delta$, although the $C Y Y Y$ distinguishes them in the case of vowels either as $\imath$ or $i$. In the $\mathrm{Wu}$ dialects, however, the sounds of the Ancient Chinese $\mathrm{E}$ and $\mathrm{F}$ groups have been assimilated to the simple sibilant group except in the Kiuchow 雔州 and Kinhwa 金華 dialects, in which $\left[t \int, t \int^{\prime}, d_{3}, \int, 3\right]$ appear very often. ${ }^{24}$ This fact suggests that in the $W u$ dialects the Ancient Chinese $t \delta, t f^{\prime}, \ldots$ series was still preserved in the Yüan period. So if the MKTY employed one of the $\mathrm{Wu}$ dialects, Nos. 5-7, 27, and 43 might have had the values $\left[\mathrm{t} f, \mathrm{t} \int{ }^{\prime}, \mathrm{d} 3, \int, j\right]$.

Denlinger's transliteration of this group follows Ligeti, Poppe, and Clauson, but his ascription of the Chinese phonemes $t s, t s^{\prime}, d z$ to Nos, 7 6,5 respectively is a great mistake. ${ }^{25}$ According to his transliteration, there is no distinction between groups $\mathrm{E}$ and $\mathrm{F}$ and group $\mathrm{G}$. This seems to be a misprint.

As regards No. 8 which was a nasal cerebral (niang-艮 initial) in Ancient Chinese, it appears only once in the $P C H$ as a character 鍵. In the $M K T Y$, this phoneme is distributed to $\tilde{n}, n$ or $\dot{r}$, although it has been completely assimilated into $n$ in the CYYY. The feature of confusion between these three phonemes is similar to that in the Wu dialects. ${ }^{26}$ This also suggests the similarity of the dialect employed in the MKTY and the $\mathrm{Wu}$ dialects. Denlinger again interprets this fact mistakenly: 'careful comparison between MKTY and Kuang-yün 億韻 with regard to

\footnotetext{
23 Source materials for Middle Mandarin include: Chiao-t'ai-yiin 交泰䁚 (1606) by Lü Kun 吕坤: Hsi-ju Erh-mu-tzu 西需耳目資 (1926) by Nicolas Trigault; Wu-fang

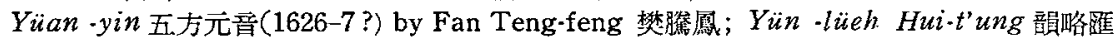
通(1642) by Pi Kung-ch'en 畢拱辰. The phonetic changes shown in stage 3 of my schema can be obviously seen in the Ssu-ma Wen-kung Teng-yün T'u-ching 司馬 溫公等潩圖經 (1606) by Hsï Hsiao 徐孝, which is supposed to have employed the sound system of Shun-t'ien 順天.

24 See Chao Yuen-ren, Hsien-tai Wu-yü te Yen-chiu, Table I, 4.

25 Op. cit., pp. 413-14, Chart Ia-9, 10, 11, 26, 27, 28 and pp. 418-19.

26 See Chao Yuen-ren, ibid; N. Osada, 'Soshūgo on'in taikei no sho tokuchō ni tsuite', $C G K R$, I (1953), pp. 35-50.
} 
his initial suggests that in this area the "archaising" of the MKTY was completely unsuccessful.' 27

With regard to the distinction between Nos. 27 and 43 , No. 43 occurs only in the MKTY which has retained all voiced initials. Clauson and Denlinger explain that No. 43 is 'peculiar' or 'archaising' without any specific reference to the $M K T Y{ }_{.}^{28}$ It is natural that Bla-ma 'Phags-pa did not invent No. 43 because it is supposed to be difficult to distinguish Nos. 43 from 7. Therefore, the phonetic values of Nos. 5-7, 27, 43 are phonetically denoted as $\left[t_{s}, t^{\prime}, d z, s, z\right]$ in Mandarin, and $\left[t \int, t f^{\prime}, d_{3}, f, 3\right]$ in the $\mathrm{Wu}$ dialects, but they can also be phonologically interpreted as $t s, t \varsigma^{\prime}, d z^{\prime}, s, z$ respectively.

\section{G : Sibilant group}

Nos. 17-19 are much different in shape from the Tibetan equivalents. Later, however, we find many other variants which are equivalent to the phonemes $t s, t s^{\prime}, d z$ in the Tibetan seal-script as follows :

\section{Table 4}

\begin{tabular}{|c|c|c|c|c|c|c|c|c|c|c|c|c|}
\hline \multirow[b]{2}{*}{ No. } & \multicolumn{3}{|c|}{ 'Phags-pa } & \multicolumn{2}{|c|}{ Devanāgarī } & \multicolumn{2}{|c|}{ Chin. trsc. } & \multicolumn{2}{|c|}{$\begin{array}{l}\text { Tib. equi- } \\
\text { valent }\end{array}$} & \multicolumn{3}{|c|}{$\begin{array}{l}\text { Tib. } \\
\text { seal-script** }\end{array}$} \\
\hline & & $F S K$ & Mong. & & & Old & New & & & & & \\
\hline 5. & $\exists$ & 者 & $z$ & - & - & - & - & $\delta$ & $c a$ & $\equiv$ & & $\Xi$ \\
\hline 6. & 王 & 車 & $\check{c}^{\prime}$ & - & - & - & - & $\Phi$ & cha & ळ, & & 五 \\
\hline 7. & $E$ & 遮 & y & - & - & - & - & $E$ & $j a$ & $E$ & & \\
\hline 8. & $\sqrt{\pi}$ & 倪 & - & अ & $\dot{n} a$ & 若 & 倪 & 3 & $\bar{n} a$ & & & \\
\hline 27. & 马 & 設 & $s$ & शT & $s a$ & 睮 & 設 & 9 & $s a$ & & & \\
\hline- & - & - & - & ष & $\underline{s a}$ & 沙 & 沙 & $p_{2}$ & șa & & & \\
\hline 43. & 与 & - & - & - & - & - & - & - & - & & & \\
\hline 17. & उन & 拶\} & $c^{\prime}$ & च & $c a$ & 遮 & 拶 & 5 & $t s a$ & 氜, & वन, & ¿ \\
\hline 18. & $\varpi$ & 擦 & & ₹ & cha & 車 & 擦 & ळ゙ & tsha & 至, & 포의, & 五 \\
\hline 19. & 그 & 惹 & $j$ & ज & $j a$ & 闍 & 惹 & $E$ & $d z a$ & 르, & $\vec{E}$ & $\sqrt{\text { 压 }}$ \\
\hline - & - & - & - & ङ & jha & 闍重 & 嵯 & - & - & & & \\
\hline 28. & $\pi$ & 沙 & $s$ & स & $s a$ & 妴 & 薩 & K & $s a$ & & & \\
\hline 22. & $\exists$ & 薩 & $z$ & - & - & - & - & $\exists$ & $z a$ & & & \\
\hline 21. & 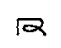 & 若 & $\check{z}$ & - & - & - & - & 9 & $z a$ & & & \\
\hline
\end{tabular}

note* The Mongolian transcription in this table follows Poppe, op. cit., pp.19-24.

** Examples of Tibetan seal-script are collected from Francke, op. cit., Walsh, op. cit. and the Rgya-dkar.nag....

27 Op. cit., p. $419 . \quad 28$ Clauson, op. cit., p. 307 ; Denlinger, ibid., p. 421. 
In this table, one should note that the Chinese transcription of the Sanskrit ca, cha, ja, jha has two different forms, as also in the case of the Sanskrit $g a, d a, b a$. Lo Ch'ang-p'ei suggests that this might be result of three factors; 1 . Indic dialects, 2. phonetic changes in Indic phonology, 3. differences between the Buddhist sects. ${ }^{29}$ In the $F S K$, the old Chinese transcription of Nos. 17-19 is removed to Nos. 5-7 and the new Chinese transcription of Nos. 17-19 is used for 'Phags-pa Nos. 17-19 respectively.

On the other hand, Nos. 17-19 of the 'Phags-pa alphabet much more resemble in shape the Devanāgari $c a, c h a, j a$ than the Tibetan equivalents $t s a, t s h a, d z a .^{30}$ According to Poppe, Nos. 17-19 have been rarely used expect for the phonemes of Chinese origin, because these phonemes have never existed in the Mongolian language. ${ }^{31}$ Therefore, Bla-ma 'Phags-pa has apparently invented Nos. 17-19 for Chinese phonemes only, and the Tibetans who have referred to Mongolian documents in 'Phagspa script might have felt it difflcult to find 'Phaga-pa equivalents of the Tibetan tsa, tsha, dza. They might also have invented Tibetan sealscript by analogy from the shape of $d b u$-can. The differrence of shape between 'Phags-pa script and the Tibetan equivalents of Nos. 17-19 is supposed to have been caused by Bla-ma 'Phags-pa's desire to avoid confusion. Otherwise, the Tibetan equivalents of Nos. 5-7 and 17-19 might easily have been confused. Hence it is considered that Bla-ma 'Phags-pa invented Nos. 17-19 on the basis of the Devanāgarì alphabet, and not on that of the Tibetan $d b u$-can as in other letters.

The use of the character 惹 for No. 19 is also the result of denasalisation. This character has jih initial $曰$, which is supposed to have a phoneme $h \dot{z}$ and which was always transcribed by the Tibetans as $z$ or Uighur $z$ (see Table 3). Therefore, it is not strange that the Tibetan

29 'Fan-wen o-yin wu-mu ...'.

so The three Tibetan letters $t s a$, tsha and $d z a$ were evidently differentiated from the palatals $c a$, cha and $j a$ respectively. 'Phags-pa perhaps tried to avoid the confusion of letter shapes between sibilants and palatals when he invented the 'Phags-pa script. Also see Clauson and Yoshitake, 'On the phonetic value of the Tibetan characters....., p. 845 , which gives a simple account of this problem.

31 Poppe, op. cit., p. 21. 
$d z a$ and $z a$ are transcribed by the Chinese $j i h$ initial, since it would have been different for the Chinese to distinguish the Tibetan $d z a$ from źa.

However, from the standpoint of Chinese phonology, the phonetic value of the $j i h$ initial in the Yüan period had already acquired a vibrant element which resulted in $\dot{r}$. In the MKTY, there is a distinction between $d z$ (chao initial 照母), $z$ (ch'an initial 㼛母), $z$ (hsieh initial 邪母) and $\dot{r}$, but the first three of these phonemes are assimilated to $t s$ $s$ and $s$ in the CYYY. According to Karlgren, the phonetic value of the jih initial in modern Mandarin is $z\left(=\left[z_{0}\right]\right),{ }^{32}$ which is apparently the coclusion of a theoretical process from $n>\hat{n}>n \hat{z}>\dot{z}$ to $z^{33}$ Careful observation of modern Pekinese illustrates that this phoneme has a strong retroflex element $[x]$ and that the actual value of modern utterance might have been derived from $\dot{r}(=[\mathrm{r}])$ at some stage in Old Mandarin. Also, Karlgren's process $\dot{n} \dot{z}>\dot{z}>z$ is inconsistent with the MKTY. Why was it necessary for Karlgren to distinguish $z$ from $z$, which are both regarded as the same in the MKTY? The character 惹 for No. 19 is, thus, the result of traditional transcription since Amoghavajra.

The character 沙 for No. 28 in the FSK should be corrected to 薩, according to the CTT, and the character 涯 for No. 22 should be also corrected to something which has an initial $z$.

Thus, the phonetic values of Nos. $17-19,28$ and 22 in this group are $t s, t s^{\prime}, d z, s, z$, respectively.

\section{$\mathrm{H}$ : Laryngeal group}

This group has given us many diffculties. The problems will be discussed in the next chapter (\$ 4).

32 Han-yü Fang-yin Tzu-hui (Paking, 1962) also adopts Karlgren's [z]. Phonetically speaking, $\left[z_{t}\right]$ is a voiced of $[s]$ in the retroflex group. But the $j i h-m u$ is not derived from the voiced of the shen-mu ; in other words, there is no phonological opposition between $s(=[\mathrm{s}])$ and $j i h \cdot m u$ in modern Pekinese. Therefore, this phoneticisation is inconsistent.

33 Maspero gives only the formulae associated with $m, n, y$. But according to Ogawa (op. cit., p. 8) this formula is also applicable to the jih.mu. Karlgren (op. cit., pp. 466-9) gives a different formula; $\mathrm{n} z>\mathrm{yg} z>\mathrm{g} z$. 


\section{I : Liquid group}

Phonetic values of Nos. 26 and 21 are $l$ and $\dot{r}$. This phoneticisation $\dot{r}$ is adequate to avoid confusion between $z, d z$, and $j i h$ initial, as mentioned above.

\section{$\mathrm{J}$ : Vowels}

Nos. $31,32,34$ should undoubtedly be $i, u$, o respectively. Ligeti's observation on the variant of No. $34(\pi)^{34}(=$ No. $34 \mathrm{a})$, which appears both in the $P C H$ and $M K T Y$, is correct, but he does not mention the peculiar final $\underline{n}$ accompanied by No. 34a. This problem will be discussed in the next chapter ( $\$ 2$ ).

Ligeti's suggestion as to No. 39 (central vowel symbol) is incorrect, and has been rectified by Clausion and Denlinger. ${ }^{35}$ Nos. 39 and 41 are very similar in shape; in the $M K T Y$ they are identical. Nos. 40 and 41 and No. $34 \mathrm{a}$ are medials. In the $M K T Y$, No. 33 is mistakenly described as $₹$ and Denlinger follows this, ${ }^{36}$ but in fact the equivalent should be $F$ or $\rightarrow$. Oshibuchi and Poppe proposed two central vowels $\ddot{o}$ and $\ddot{u}$ which are compound shapes of No. 41 and Nos. $32,34 \mathrm{a} .{ }^{37}$ The central vowels are unknown before the advent of modern Chinese, so they should rather be diphthongs in the MKTY or other Chinese 'Phags-pa documents. There were, however, central vowels in Mongolian, as Poppe has noted. Chinese transcription of Sanskrit, as far as the vowels are concerned, is much different from that in the FSK. For instance, the character for No. 33 has been used to transcribe the Sanskrit $\bar{i}$, but in the 'Phags-pa alphabet it is $\varepsilon$.

\section{$\mathrm{K}: \quad$ Miscellanea}

No. 25 was invented solely to transcribe the Mongolian $r$, and was omitted from Chinese material. The Mongolian $r$ is a 'strong rolled alveolar

\footnotetext{
34 'Trois notes sur l'écriture 'phags-pa', $A O H$, XIII (1961), pp. 201-37, especially pp. $212-25$.

35 Clauson, 'The hp'ags-pa alphabet', pp. 319, 322 ; Denlinger, op. cit., p. 428.

36 Denlinger, ibid., pp. 425-6.

37 Oshibuchi, 'Chügenon'in chū no.....' p. 606 ; Poppe, op. cit, p. 25.
} 
sound'38 and in the Tsung-k'uo Pien-hua chih t'u 總括變化之圖 in the $M K T Y,{ }^{39}$ it is annotated as chuan-she-erh 轉舌兒. This seems that the Mongolian $r$ was similar to Chinese retroflex vibrant $\dot{r}$. The reason why No. 25 was not transcribed by $j i h$ initial character but was transcribed by the lai initial (來母) character ( $l$ ) is also a result of the traditional transcription of the Chinese Buddhist texts.

As regards No. 38 , this seems to have been invented to transcribe the Sanskrit $a h$ as seen in the CTT. Later, however, this letter became completely useless to transcribe Chinese and Mongolian.

38 Poppe, Grammar of Written Mongolian, p. 13.

$39 \quad M K J I$ (Kansai Daigaku ed.) p. 7; PSPT ed., p. 97a. 


\section{III \\ 'PHAGS-PA ORTHOGRAPHY IN CHINESE DOCUMENTS}

\section{\$ 1 Alternation between Voiced and Voiceless Initials}

It has been frequently said that in the 'Phags-pa transcription of Chinese, voiced and voiceless initial consonants usually alternate. In fact, this phenomenon can be seen in both the PCH and MKTY as follows:

\begin{tabular}{crrll}
\hline group & No. & 'Pgs. & & Chin. \\
\hline \multirow{2}{*}{ A. } & 3 & $g$ & $\vdots$ & $k$ \\
& 1 & $k$ & $\vdots$ & $g$ \\
\hline \multirow{2}{*}{ B. } & 15 & $b$ & $\vdots$ & $p$ \\
& 13 & $p$ & $\vdots$ & $b$ \\
\hline \multirow{2}{*}{ D. } & 11 & $d$ & $\vdots$ & $t$ \\
& 9 & $t$ & $\vdots$ & $d$ \\
\hline E.F. & 7 & $d z$ & $:$ & $t s$ \\
\hline \multirow{2}{*}{ G. } & 5 & $t s$ & $:$ & $d z$ \\
\hline
\end{tabular}

However, in the following cases this phenomenon does not appear :

\begin{tabular}{ccccc}
\hline G. & 37 & $f$ & $\vdots$ & $f$ \\
& 42 & $v$ & $\vdots$ & $v$ \\
\hline F. & 27 & $\S$ & $\vdots$ & $s$ \\
& 43 & $z$ & $\vdots$ & $z$ \\
\hline G. & 28 & $s$ & $\vdots$ & $s$ \\
& 22 & $z$ & $\vdots$ & $z$ \\
\hline H. & 29 & $h$ & $\vdots$ & $h$ \\
& 44 & $h$ & $:$ & $h$ \\
\hline
\end{tabular}

That is to say, the alternation of voiced and voiceless initials always occurs in the plosive group (including affricated sounds) and not in the fricative group.

On this problem, Karlgren states:

La supposition $b^{\prime}, d^{\prime}, g^{\prime}$ etc. nous donne aussi la clef d'un autre problème. Les transcriptions mongoles ont régulièrement des sourdes pour les sonores 
chinoises et des sonores pour les sourdes chinoises. Or, si l'on interprète les sonores de l'ancien chinois par $b, d, g$ etc., il sera tout à fait incompréhensible que les mongols aient entendu $p$ pour $b$ et $b$ pour $p$. Mais en supposant que les phonèmes de l'ancien chinois ont été $b^{\prime}, d^{\prime}, g^{\prime}$ etc. et qu'en mongol les sourdes $p, t, k$ ont étá plus aspirées que les sonores $b, d, g$ - ce qui est la règle par ex. dans les langues germaniques - on ne trouvera rien d'étonnant à ce que le $b^{\prime}$ chinois, à cause de son aspiration, ait été perçu par les mongols comme un $p^{\text {, }}$, et qui la sourde faible chinoise $p$, vu son manque d'aspiration, ait été perçue comme un $b, 1$

According to Karlgren, this phenomenon can be indicated as the following scheme :

$$
\begin{aligned}
& \text { Chin. Mong. 'Pgs. } \\
& \text { stage } 1 . \quad b^{\prime} \longrightarrow \longrightarrow p\left(=\left[\mathrm{p}^{\prime}\right]\right) \longrightarrow p \\
& \text { Scheme } I \text { stage 2. } \quad p \longrightarrow-\rightarrow b \longrightarrow b \\
& \text { stage 3. } p^{\prime} \longrightarrow \longrightarrow \longrightarrow p^{\prime}
\end{aligned}
$$

On the evidence of alternation between voiced and voiceless initials in the Chinese and Mongolian languages, Karlgren concludes that Ancient Chinese voiced initials were aspirated. Chiang Yung 江永 and Ch'en $\mathrm{Li}$ 陳潧 assigned the voiced initials to the aspirated group, ${ }^{2}$ which would accord with Karlgren's hypothesis, and Lo Ch'ang-p'ei produces evidences from Chinese Buddhist texts to support this conclusion. ${ }^{3}$ However, Lu Chih-wei and A. Tôdō hold the opposite view, ${ }^{4}$ and Chao Yuan-ren, although he in general follows Karlgren's hypothesis, still leaves the question open. $^{5}$ Thus it is difficult to associate the phenomenon of alternation between voiced and voiceless initial in 'Phags-pa with the presence of aspiration in Ancient Chinese voiced initials, until the presence of aspiration in Ancient Chinese has itself been proved more conclusively.

As there is no phonological opposition concerning aspiration in Ancient Chinese voiced initials, it is possible to deal phonologically with Ancient Chinese voiced initials without further reference to Karlgren's theory.

1 Karlgren, Études sur la phonologie chinoise, p. 360.

2 Chiang Yung, Yin-hsuieh Pien-wei 音學辨微: Ch'en Li, Ch'ich-yün k'ao wai-pien 切䫓考外篇.

3 Lo Ch'ang-p'ei, T'ang Wu-tai Hsi-pei Fang-yin, pp. 27-30.

4 Lu Chih-wei, 'Shih CYYY', YCHP, XXXI (1946), p. 38, n. 2; A. Tc̄dō, Chagokugo On'inron, pp. 158-61.

5 Chao Yuen-ren, 'Lun ch'ing-cho', AS, XXX, 2 (1959), pp. 493-7. 
In Ancient Chinese there is a phonological opposition between voiced, voiceless aspirated and voiceless non-aspirated initials (e. g. $b: p^{\prime}: p$ ) in each group. On the other hand, in Mongolian there is a phonological opposition only between voiced and voiceless initiali (e. g. $b: p / b: p^{\prime}$ ).

Voiceless initials are all strong aspirated, ${ }^{6}$ so we can also denote them $p$ ' because there is no phonological opposition between them.

It can be supposed that the alternation between voiced and voiceless initials in 'Phags-pa transcription of Chinese is caused by the differences of phonological opposition in Chinese and Mongolian. The Mongols, who did not possess a phonological opposition between aspirated and nonaspirated initials, might have noticed the phonological opposition between them of Chinese. In this case, the transcription should be as follows:

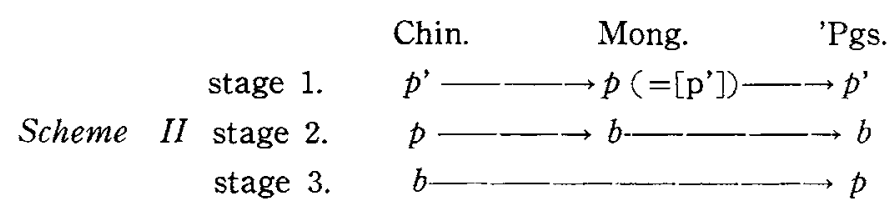

In this scheme, Chinese and Mongolian naturally correspond to each other; however the voiced initial $b$ excluded from Chinese in stages 1 and 2 should be replaced by $p$ which is also excluded from 'Phags-pa transcription in the stages 1 and 2 . Therefore it can be said that stages 1 and 2 are a natural alternation from the Mongolian point of view, but stage 3 is an artificial alternation introduced from a comparison with Chinese usage.

Another explanation is also possible. In the T'ang period, the Uighur script tended to transcribe Chinese voiced initials (except nasals) by voiceless initials. ${ }^{7}$ This was influenced by the denasalisation of the Northwestern dialects as discussed in Chapter II. This can be shown as follows :

6 See Poppe, Grammar of Written Mongolian, pp. 12-5; Introduction to Mongolian Comparative Studies, pp. 95-171.

7 See Csongor, 'Chinese in the Uighur script of the T'ang-period', pp. 110-9.

(comparative list of the Middle Chinese glosses in Uighur script)in which one may

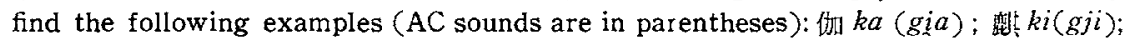
昆 $p i(b j i)$; 大tai (dai); 弟 $t a i i(d i e i) ; \quad$ 己 $k i(k j i)$; 般pan (puan); 等 tang

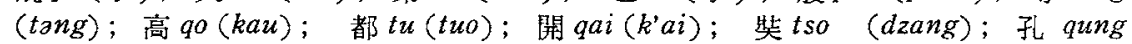
(k'ung)；統tung (t'ung)；摩ba (mua)；色 gii (ngjwie); 彦 gen (ngjiän); etc. 


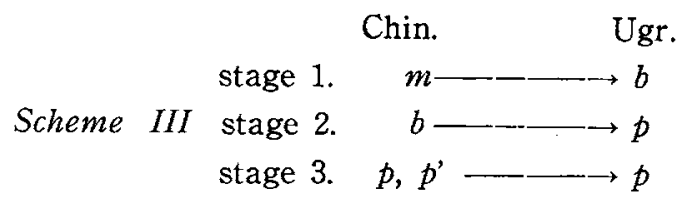

In the Yuan period, however, the Uighur transcription of Chinese was influenced by phonetic changes in Old Mandarin, by which voiced initials were distributed to either aspirated or non-aspirated voiceless initials depending upon their tones. Therefore, in Old Mandarin there is simply an opposition between aspirated and non-aspirated voiced initials. The Mongols regarded this phonological opposition in Old Mandarin as that between voiced and voiceless initials ${ }^{8}$. So in the case of Mongol, alternation might have occurred as follows:

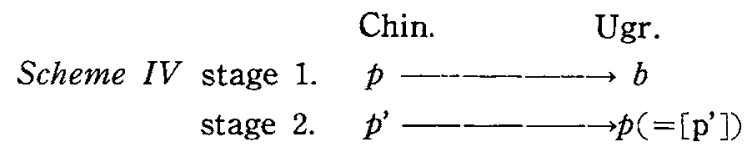

This principle had apparently already been established when the 'Phags-pa script came into existence. ${ }^{9}$ In the 'Phags-pa transcription of Chinese, the alternation suggested above also took place. In order to transcribe the voiced initials which were still retained in the non-Mandarin area, 'Phags-pa script had to use the only group of letters available, as follows:

8 Cf. F.W. Cleaves, 'The Sino-Mongolian inscription of 1362 in memory of Prince Hindu', HJAS, XII (1949), pp. 1-133+27 plates, esp. see pp. 69-82, 'Index verborum Mongolicorum'. In this index, the following examples may be seen (Pekinese sounds in parentheses)：伯 bai (pai/po); 部 $b u(p u)$; 籼 bun (p'an);

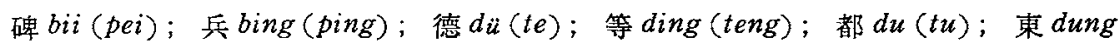

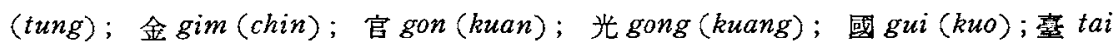
(t'ai); 腾ting (t'eng); 同 tung (t'ung); etc. The Uighur transcription of Chinese has definitely been influenced by old Mandarin. Furthermore, in the tentative romanisation of Chinese put forward in 1957 in mainland China, the phono. logical opposition between aspirated and non-aspirated initials is replaced by that between voiced and voiceless initials. The Japanese also tend to regard Chinese $p: \not p$ as $b: p$ respectively.

9 Hope also gives an explanation of alternation in the 'Phags-pa transcription of 


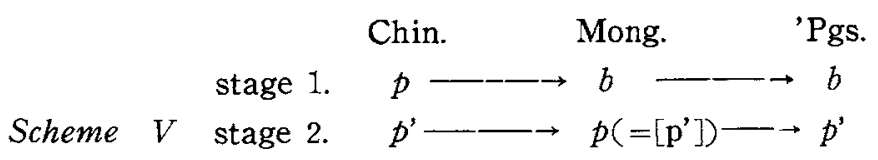

stage 3. $\quad b \longrightarrow \longrightarrow \longrightarrow-\longrightarrow p$

In this scheme, stages 1 and 2 are identical with those in Scheme $I V$, and stage 3 was necessarily added to transcribe the non-Mandarin voiced initials as seen in the MKTY and PCH. E.R. Hope's scheme is identical with the above Scheme $V$, but his intention is apparently to illustrate the alternation between 'clear null' and 'muddy null' pitches. He states, 'The Tibetan muddy null $\{$, which has the same tone as $\mathrm{KH} / \mathrm{Gh}[g]$, TH/Dh $[d]$ etc, becomes the clear-pitch null of Chinese, while the Tibetan clear-pitch null $\mathrm{W}$, which is of the same tonal series as the initials $\mathrm{G}$ $[k], \mathrm{D}[t]$, etc. becomes the muddy null in Chinese. ${ }^{10}([]$ indicates my adjustment.)

In the 'Phags-pa Mongolian documents, as Poppe points out, ${ }^{11}$ the confusion of fortes and lenes, especially initially, occurs. Although no explanation about this phenomenon is given by Poppe, it should be noted that in the 'Phags-pa Mongolian documents alternation between fortes and lenes does not occur but simply the confusion between them occurs. In Mongolian consonantalism, there is a phonological opposition between voiceless and voiced initials (e.g. $p / k: b / g$ ). Normally, how. ever, according to Poppe, the Mongolian voiceless stops are strong aspirated fortes. ${ }^{12}$ Also in Uighur orthography, the letters denoting $p / k$ and $b / g$ are not distinguished from each other; in other words, only one Uighur letter is provided to denote either $p / k$ or $b / g$. Since $p / k$ and $b / g$ are phonetically $\left[\mathrm{p}^{\prime}\right] /\left[\mathrm{k}^{\prime}\right]$ and $[\mathrm{b}] /[\mathrm{g}]$ respectively, these two

Chinese: 'Evidently the identification of Mongol $G[g]$ with Chinese $G[k]$ was already established at the time, and too strongly established to allow any change to be made.' (Karlgren's Glottal Stop Initials..., p. 35), but he gives no reference or reason for this phenomenon.

10 Hope, ibid, p. 36.

11 Poppe, Mongolian Monuments ..., p. 33.

12 Poppe, Grammar of Written Nongolian, pp. 12-5. 
phonemes are to be distinguished from each other, but they have no orthographical distinction at all. After the 'Phags-pa script was introduced, the letters denoting the voiceless aspirated consonants $p$ ' and $k^{\prime}$ were added to Mongolian documents. Thus, in 'Phags-pa Mongolian documents, the phonemes $p$ and $k$, which were phonetically $[\mathrm{p}]$ and $\left[\mathrm{k}^{\prime}\right]$, were represented by using the 'Phags-pa letters $p$ ' and $k$ ', while the 'Phags-pa letters $p$ and $k$ were used for representing $p$ and $k$ in the words of foreign origin. ${ }^{13}$ The confusion of $p^{\prime} \mid k^{\prime}$ and $b / g$ in the 'Phags-pa Mongolian documents took place of that of $p / k$ and $b / g$ in the Uighur orthography. This phenomenon is, thus, to be regarded as a consequent development from the Uighur orthography and not to be regarded as a phonological confusion between fortes and lenes.

Hattori also explains the confusion between fortes and lenes in the 'Phags-pa Mongolian documents and ascribes it to the result of the Tibetan transcription of Mongolian which tended to transcribe the Mongolian voiceless aspirated by the 'Phags-pa voiced letters, as in the Lhasa dialect of Tibetan of the time the voiced was actually pronounced like voiceless. ${ }^{14}$ This explanation is, however, hardly acceptable unless the fact that the Tibetans in Lhasa transcribed Mongolian in the 'Phagspascript is proved. The 'Phags-pa script is supposed to have not been used in Tibet at the time but only been used in Mongolian and China.

On the one hand, Hattori also explains tne peculiar phenomenon of alternation between voiceless and voiced initials in 'Phags-pa Chinese documents. Hattori states: 'At the time, the principle that the Chinese voiceless non-aspirated was represented by the 'Phags-pa voiced letters and the Chinese voiceless aspirated was represented by the 'Phags-pa aspirated letters was established, because the Chinese and Mongolians of the time, in comparing their languages, regarded the Mongolian voiced/ voiceless aspirated as the Chinese voiceless non-aspirated/voiceless aspirated. Thus, the Chinese voiced aspirated which did not exist in Mongolian was necessarily represented by the letters derived from the Tibetan voiceless letters.' ${ }^{15}$ This can be deduced as Scheme VI shows:

13 See Poppe, Mongolian Monuments.., pp. 19-21, esp. Nos. 5, 11, 12 and 21.

14 Hattori, Genchōhishi no Niōkogo..., p. $68 . \quad 15$ Hattori, ibid., p. 67. 


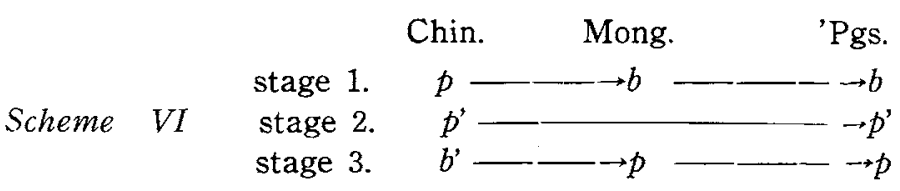

Although Hattori's premise of this explanation that the Chinese voiced initials were aspirated as Karlgren's cannot be accepted, his interpretation mentioned above illustrates that the alternation of Chinese voiced and voiceless initials in the 'Phags-pa orthography was a result of difference of phonological opposition between the Chinese and Tibetan languages and Mongolian language. That is to say, the Mongolian language has only distinction between sonants and surds, while the Chinese and Tibetan ('Phags-pa) languages have the phonological opposition between aspiration and non-aspiration as well as sonants and surds.

\section{$\S 2$. The Peculiar $n$}

The phoneme $n$ is usually denoted as No. 12 ( $\approx$ ) in the 'Phags-pa script. However, only in the $M K T Y$ a variant of No. 12 ( $/$ ) appears regularly, and this letter is always accompanied by the vowel ( $\pi$ ) which is also a variant of No. $34(\pi)$ and which occasionally appears in Mongolian documents. ${ }^{16}$ Concerning the distribution of $\pi$ and $\pi$, Ligeti has proposed a comprehensive theory, ${ }^{17}$ but he gives no mention of $₹$ accompanied by $\pi$.

The distribution of $\bar{\alpha}$ and $\pi$ in the $P C H$ and $M K T Y$ is as follows:

\begin{tabular}{|c|c|c|c|c|c|c|}
\hline \multicolumn{4}{|c|}{$A C$} & $C Y Y Y$ & $P C H$ & $M K T Y$ \\
\hline 黃 & huang & （宕攝 1，合， & 匣母) & hwang & rôn & rôn \\
\hline 岏 & puan & （山攝 1, 合 & ) & - won & - & on \\
\hline 官 & kuan & $"$ & ) & kwon & gôn & gôn \\
\hline 賁 & $k^{\prime} u a n$ & $"$ & ) & $k^{\prime}$ won & - & $k^{\prime} \hat{o n}$ \\
\hline 端 & tuan & $"$ & ) & twon & - & $d \hat{n} n$ \\
\hline
\end{tabular}

16 In Mongolian documents, Ligeti's $\hat{o}$ occurs in many cases, but the most peculiar case should be found in the word $m \hat{o} n g k$ ' $a$ ('eternal') in the initial formula of edicts. See W. Kotwicz, 'Formules initiales des documents mongols aux XIII-e et XIV-e ss.,' $R O, 10$ (1934) pp. 131-57 ; Poppe, Mongolian Monuments..., pp. 68-72 ; Pelliot, 'Un rescrit mongol en écriture 'phags-pa', TPS, II, pp. 621-4; Ligeti, ibid.

17 Ligeti, 'Trois notes ..., ' pp. 212-25. 


\begin{tabular}{|c|c|c|c|c|c|c|}
\hline 湍 t'uan & ( & $"$ & ) & $t^{\prime} w o n$ & - & $t^{\prime} \hat{o} \underline{n}$ \\
\hline 段 duan & $c$ & $"$ & ) & t'won & tôn & tón \\
\hline 暖 nuan & $c$ & $" 1$ & ) & nwon & - & $n \hat{o} \underline{n}$ \\
\hline 潘 p'uan & ( & $"$ & ) & p'won & pôn & $p^{\prime} \hat{n} \underline{n}$ \\
\hline 滿 muan & ( & $"$ & ) & mwon & $m \hat{n}$ & $m \hat{o n}$ \\
\hline 桓 ruan & $c$ & $"$ & ) & hwon & rôn & rôn \\
\hline 欒 luan & $c$ & $" H$ & ) & lwon & lôn & $l o \hat{n}$ \\
\hline 靰 kĩu $\Lambda n$ & （山攝 3, & 合 & ) & kjwen & -- & geôn \\
\hline 勸 $k^{\prime} \breve{z} u A n$ & $c$ & $"$ & ) & $k^{\prime} j w e n$ & - & $k^{\prime} e \hat{o} \underline{n}$ \\
\hline 戀 ľuAn & $c$ & $"$ & ) & ljwen & - & leŝn \\
\hline 浮 biou & （流攝 3 , & 開， & 唇亘) & $f u$ & $f u$ & fôw \\
\hline pц̌əu & ( & $n$ & ) & $f u$ & $f u$ & fôw \\
\hline
\end{tabular}

Ligeti's $\hat{o}$ or Hattori's $\theta$ in Chinese documents are considered to be denoted as [0] phonetically, because the nucleus is evenly the back-vowel [a] and the medial preceding it is also a back-vowel [ $\mathbf{u}$ ] in the 1st-degree of the both shan-she L攝 and tang-she 宿攝. On the other hand, 2nd-degree of these groups had a nucleus [a] and medial [w]. From these facts, it is supposed that the medial $[u]$ in these groups was much stronger than ordinary medial $[\mathrm{w}]$, so it is possible to assume that this medial [ $\mathrm{u}]$ has a tendency to assimilate [a] into [ $\mathbf{u}$ ] itself. Even in the CYYY this phenomenon occurs; the nucleus [a] in Ancient Chinese changes to [o] being attracted by the medial [u]; as a result of this medial [u] changes to [w] and the nucleus [a] changes to [o]. Similarly, in the $M K T Y$ as a result of mutual atraction, either [o] or [0] can appear. In this case, $\hat{o}$ (or $\rho$ ) should be [0], because [o] had already appeared in the $M K T Y$ as follows.

$$
\begin{gathered}
\text { shan, tang (-she), 1st h.k. } \quad\left\{\begin{aligned}
\text { CYYY } & \text { MKTY } \\
\text {-uang } \rightarrow[- \text { won }] & {[- \text { wan }] }
\end{aligned}\right] \\
\text {,"-on }]
\end{gathered}
$$


On the other hand, Hattori denotes $\propto$ as $n$ to distinguish it from other ordinary $n$, though he does not give any explanation of $n .{ }^{18}$ As seen in the $M K T Y$, this letter has obviously the different function from ordinary $n$. In the Genroku edition of the $P C H$, this letter appears often, but they are apparently misprints which 'Ts'ai Mei-p'iao corrected in the $P S P T .{ }^{19}$ Another evidence of the existence of the letter $\propto$ is the table of seal-script forms of the 'Phags-pa script. According to this table, ${ }^{20}$ each letter of the 'Phags-pa script has at least one seal-script form; e. g. No. 12 ( $\approx$ ) has three seal-script forms; $\square$, and an , and the variant of No. $12(\propto)$ has one; 西. From this it would seem to follow that two letters $\bar{\sigma}$ and $\varnothing$ had differrent functions. This may be confirmed by some considerations of modern dialects as follows:

Table 5

\begin{tabular}{|c|c|c|c|c|c|c|c|c|c|c|c|}
\hline final & \multicolumn{10}{|c|}{ shan-she 山攝 } & \multirow{4}{*}{$\begin{array}{c}\text { chen- } \\
\text { she } \\
\text { 臻攝 }\end{array}$} \\
\hline$k^{\prime} a i \cdot h_{0}$ & \multicolumn{3}{|c|}{ k. k. } & \multicolumn{7}{|c|}{ h. k. } & \\
\hline degree & 1,2 & 3 & 4 & 1 & 2 & \multicolumn{4}{|c|}{3} & 4 & \\
\hline initial & & & & & & $\mathrm{k}, \mathrm{h}$. & $t s$. & $f-$ & & & \\
\hline Soochow & E & $\mathrm{E}, \varnothing$ & I & \multicolumn{2}{|c|}{$\varnothing$} & iø & $\varnothing$ & $\mathrm{E}$ & I & $\mathrm{i} \Im$ & $\mathrm{n}$ \\
\hline Wenchow & $\mathrm{a}$ & $\mathrm{a}, \mathrm{i}$ & $\mathrm{i}$ & \multicolumn{2}{|c|}{$\varnothing$} & \multicolumn{2}{|c|}{$\mathrm{y}$} & a & & $\mathrm{y}$ & I \\
\hline Yangchow & $\tilde{\varepsilon}$ & $\hat{\varepsilon}, \tilde{\imath}$ & $\tilde{I}$ & uõ & $\tilde{\varepsilon}$ & ỹ & นõ & $\tilde{\varepsilon}$ & & ỹ̃ & $\mathrm{n}$ \\
\hline
\end{tabular}

18 Hattori, op. cit., p. 44.

19 PSPT, pp. 45-52.

${ }^{20}$ The table of the seal-script forms of the 'Phags-pa script in the MKTY is defectively compiled, e.g. $k^{\prime}$ and $d z$ appear in duplicate, the seal-script forms of $f$ and $t$ are too artificial, the seal-script form of $d$ is obviously a mistake, etc. But some of seal-script forms of the 'Phags-pa script in this table resemble those in the Tibetan seal-script, e.g. $j, y, l, s, \dot{z}, u, i$, etc. These seal-script forms were also sometimes used in epigraph inscriptions, and the Tibetans might have used these Chinese inscriptions in the 'Phags-pa script as models in inventing their own seal-script. Although the 'Phags-pa script is also called 'square script', some letters include round strokes such as in $\bar{\kappa}, W, \pi, \bar{\sigma}$ and $\sigma$. These letters are not suitable for seal-script, so the Chinese made them square as in the sealscript forms of Chinese characters. 


\begin{tabular}{|c|c|c|c|c|c|c|c|c|}
\hline Sian & \multicolumn{7}{|c|}{ a } & \multirow{2}{*}{$\frac{\widetilde{\mathrm{e}}}{\mathrm{y}}$} \\
\hline Taiyuan & $\widetilde{æ}$ & $\varepsilon$ & & & $\widetilde{\not}$ & & $\varepsilon$ & \\
\hline Amoy & $\mathrm{n}$ & $\mathrm{n}, \tilde{\mathrm{i}}$ & $\mathrm{n}, \tilde{\mathrm{a}}$ & uæ̃ & & $\mathrm{n}$ & & \\
\hline Foochow & & & & & $\eta$ & & & \\
\hline Mandarin & & & & & n & & & \\
\hline
\end{tabular}

(This table is based on the Han-yü Fang-yen Tzu-hui.)

This table shows different variants of the final consonant $n$ in modern dialects. From this table the following facts can be deduced: (1) in Peking and some other Mandarin-speaking areas the final $n$ has not changed; (2) in Foochow $n$ has evenly changed to $\eta$; (3) in Amoy it has not changed except for occasional nasalisation; (4) in both the Sian and Taiyuan dialects it has also been nasalised apart from $y$ of chen-she in Taiyuan; (5) in Yangchow (in the Mandarin-speaking area) it has been nasalised except chen-she ; (6) in the Wu dialects (Soochow and Wenchow) it has been dropped in the shan-she group, but in the chen-she group it has been kept except in Wenchow, where it has changed to $\eta$.

Comparing this table with the distribution of $n$ in the MKTY, we see that $\underline{n}$ which is a variant of $n$ cannot correspond to the Mandarin $n$ because in Peking and some other Mandarin-speaking areas $n$ has been a very stable dental plosive.

Most of Mandarin speaking areas, therefore, should be excluded from the possibility of accordance because the chen-she group in the $M K T^{\prime} Y$ has an ordinary $n$, although in Sian and Taiyuan it usually changed to either $y$ or nasalised sounds. Similarly Foochow can be excluded because $n$ has evenly changed to $\eta$. The Amoy dialect can also be excluded, because this dialect has retained an ordinary $n$ in ho- $k^{\prime}$ ou while in the MKTY $n$ had changed to the peculiar $n$ under the similar conditions to the Amoy dialect. Therefore, the possibility of similarity between the $M K T Y$ and modern dialects concerning the peculiar $n$ may be connected 
with one of the dialects of Soochow, Wenchow, or Yangchow. The Soochow and Wenchow dialects belong to the Wu dialects and the Yangchow dialect belongs to the Mandarin-speaking area (though Yangchow situates nearer to the $\mathrm{Wu}$ dialects area). The Yangchow dialect is more strongly influenced by the Wu dialects, although it still keeps some peculiarities of Mandarin; for example it has no retroflex initials, keeps the entering-tone as a glottal stop, and its proportion of the nasal final consonants reserved is similar to that of the $\mathrm{Wu}$ dialects etc., although it has dropped the voiced initials as in most of the Mandarin dialects.

In the $\mathrm{Wu}$ dialects (in this case, the Yangchow dialects is for convenience included in this group), the yang-lei 陽類 final group ${ }^{21}$ has a tendency to change depending on nature of their preceding nuclei regardless their original nature in Ancient Chinese.

According to Tōdo, in the Soochow dialect there is a phonological opposition between $n$ and $\eta$ similar to Pekinese, and this opposition can be denoted as [n], [n] and [ã] (nasalised) phonetically. ${ }^{22}$ However, these sounds supplement each other as follows:

$$
\text { 根：更 新 : 星爭俩 工 }
$$

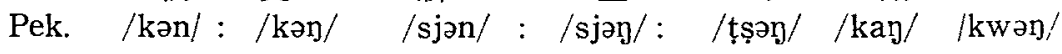

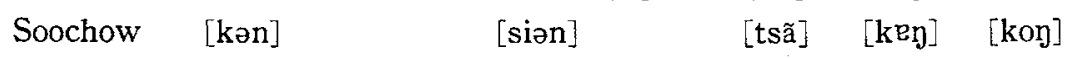

In other words, [n] appears after the back-vowel [n] and [o], [n] appears after the front-vowel [ə] and nasalisation occurs after [a].

${ }^{21}$ In the traditional Chinese phonology, the final consonants can be divided into the following threes groups:

\begin{tabular}{c|c|c|l}
\hline $\begin{array}{c}y i n-l e i \\
\text { 陰類 }\end{array}$ & $\begin{array}{c}\text { yang-lei } \\
\text { 陽類 }\end{array}$ & $\begin{array}{c}j u-l e i \\
\text { 入類 }\end{array}$ & \\
\hline \multirow{2}{*}{$a$} & $-a n g$ & $-a k$ & $\begin{array}{l}\text { ends with } \\
\text { velars }\end{array}$ \\
$-a j$ & $-a n$ & $-a t$ & $\begin{array}{l}\text { ends with } \\
\text { dentals }\end{array}$ \\
$-a w$ & $-a m$ & $-a p$ & $\begin{array}{l}\text { ends with } \\
\text { bilabials }\end{array}$ \\
\cline { 2 - 4 } & $-a p$ & \\
\hline $\begin{array}{l}\text { ends with } \\
\text { null }\end{array}$ & $\begin{array}{l}\text { ends with } \\
\text { nasals }\end{array}$ & $\begin{array}{l}\text { ends with } \\
\text { plosives }\end{array}$ & \\
\hline
\end{tabular}

A. Tōdō, op. cit., pp. 59-62. 
Therefore, from the viewpoint of phonology we can state that there is only one phoneme $n$ denoting the nasal final consonant in the Soochow dialect.

The latest observation of the Wu dialects also supports Tödö's explanation, though there are some differences between them on some minor points. The following table shows distribution of the yang-lei group. ${ }^{23}$ Table 6

\begin{tabular}{|c|c|c|c|c|c|c|c|c|}
\hline \multirow{2}{*}{ dialects } & \multirow{2}{*}{ 山, 咸 } & \multicolumn{2}{|r|}{ 瑧, 深 } & \multirow{2}{*}{ 宕 } & 梗 & 通 & \multicolumn{2}{|c|}{ 曾 } \\
\hline & & & k. k., 3 & & k.k.3,4 & h.k.3 & & k.k. 3 \\
\hline Yangchow & nasalised & $\mathrm{n}$ & nasalised & $n$ & $\mathrm{I}$ & $\mathrm{y}$ & $\mathrm{n}$ & $\mathrm{i}$ \\
\hline Soochow & $E, \varnothing, \quad x$ & & n & $\mathfrak{n}$ & I & n & & $\mathrm{n}$ \\
\hline Wenchow & $a, \varnothing, y$ & & $\mathrm{y}$ & $\rho \varepsilon$ & $\eta$ & $|n| ⿰$ & & $n$ \\
\hline Mandarin & & $\mathrm{n}$ & & & & I & & \\
\hline
\end{tabular}

As shown before, in the MKTY the group which has a peculiar $n$ appears only in the 1st-degree and a part of the 3rd-degree of ho-k'ou in the shan-she group. It therefore follows that this peculiar $\underline{n}$ would denote a transitional feature of either nasalisation in the Yangchow dialect or the disappearance of the final $-n$ in the Soochow and Wenchow dialects from the phonetical viewpoint.

Phonetically speaking there are four variants of the dental nasal stop as follows :

1. [y] : stop articulated with either blade, a front of the tongue or both.

2. [n] : stop articulated with front of tongue and front of palate.

3. [n] : nasalised; e. g. $\widetilde{a}, \widetilde{o}$.

4. $[\mathrm{N}]$ : loose stop articulated with back of tongue and rearmost part of back palate (including the uvula).

Among them, 1 and 2 can be phonologically denoted as $/ \eta /$ or $/ \tilde{n} /$, which appear as palatalized [ñ] in the MKTY. Therefore these two pho-

23 Han-yü Fang-yin Tzu-hui. Also investigation in Chao Yuen-ren's Hsien-tai Wu-yü te Yen-chiu is the same as above. 
nemes cannot be identified with the peculiar $\underline{n}$. If the stop articulated with blade and alveole ( $[\mathrm{n}]$ ) loosens and the point of articulation retreats to the back, then it changes to either nasalised [n] or post-velar [N]. The peculiar $\underline{n}$ in the $M K T Y$ is supposed to be one of these, and [n] or [N] have been loosened even more to complete the disappearance of $n$ as in modern Wu dialects. In this paper, especially in Chap. IV, $\$ 6, I$ shall use the sign $\mathrm{N}$ in denoting this peculiar $\underline{n}$, since at the time of the MKTY, nasalisation is considered to have not yet sufficiently undergone even in the $\mathrm{Wu}$ dialects.

\section{$\S 3$ The Vocalism of Peculiar $b$}

In both the $P C H$ and $M K T Y$ especially in the $M K T Y$, a peculiar $\underline{h}$ which vocalises as a medial appears frequently. Dragunov and Ligeti have discussed this but not in any detail, and Clauson and Denlinger have followed their conclusions. ${ }^{24}$ The distribution of vocalic $\underline{h}$ in the MKTY is as follows :

\begin{tabular}{|c|c|c|c|c|c|}
\hline & & $\mathrm{AC}$ & $C Y Y Y$ & $P C H$ & $M K T Y$ \\
\hline 證 & $\tan g$ & （曾攝, 1 , 開 & tang & $t \ddot{i n}$ & dhing \\
\hline 爭 & tșang & (梗攝，2，開， E,F) & $t \operatorname{sang}$ & - & dzhing \\
\hline 生 & füeng & $("), 3$, 開, F ) & șang & - & zhing \\
\hline 史 & $s \breve{z}$ & (止捼, 2 , 開, F ) & $s ̦ i$ & $\check{s i}$ & $z h i$ \\
\hline 司 & $s i$ & (" ${ }^{\prime \prime}, 4$, 開, G) & $s \imath$ & $s i$ & $s \underline{h i}$ \\
\hline 瑟 & șet & (瑧攝, 2 , 開, F入) & $s ̦$ & - & $2 h i$ \\
\hline 㦼 & $t s ̧ \not p$ & (深攝, 2 , 開, F入) & - & - & $d z \underline{h} i$ \\
\hline 德 & $t a k$ & (會攝, 1, 開, 入) & $t a j$ & - & $d \underline{h i j}$ \\
\hline 色 & $s ̧ k$ & (" & $s \partial i$ & - & $z h i j$ \\
\hline 根 & $k a n$ & (榛攝, 1 , 開 & $k a n$ & - & ghin \\
\hline 臻 & $t s ̧ a n$ & $(" \prime, 2$, 開, F) & $t s ̦ a n$ & - & dzhin \\
\hline 鈎 & kau & （流攝，1, 開 & $k a u$ & $g i w$ & ghive \\
\hline 刨 & $t s ̦ \partial u$ & $(" \prime, 2$, 開, F) & $t s ̦ a u$ & $j \ddot{i} w$ & $d z h i w$ \\
\hline 笒 & dzam & (深攝, 2, 開 F) & $t s^{\prime} \partial m$ & cim & țshim \\
\hline 莊 & tșang & (宕攝, 2, 開 F) & tșwang & jian & dzhang \\
\hline
\end{tabular}

24 Dragunov, op. cit., p. 30; Ligeti, 'Le Po kia sing...', pp. 11, 14 (n. 41); Clauson, 'The $h$ P'ags-pa alphabet', p. 320 ; Denlinger, op. cit., pp. $416,427$. 
From this table of distribution, the following formula can be deduced:

$\mathrm{AC}$

CYYY MKTY

（1） -2. （曾, 傣, 流, 1)

（2） -a. （會, 傃, 流, 梁 $2, \mathrm{E}, \mathrm{F}$ )

(3) $\quad-t \cdot \quad(15,2, F)$

(4) $\quad-i-(\mathbb{2}, 4, \mathrm{G})$

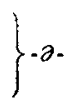

-ang

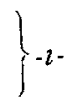

$-\underline{h} i$.

As far as (1) is concerned, there are very few dialects whose nucleus of the 1st-degree final has changed to the deflected sounds, ${ }^{25}$ except the Shuangfeng and Amoy dialects. ${ }^{25}$ Therefore, it may be easily suppos. ed that - $h i$ - in the MKTY is not a deflected sound but one of the straight sounds, As far as (2), (3) and (4) are concerned, the supradental had already lost the deflected element (-i-) by this time, both in the Mandarin-speaking area and amongst the Wu dialects. In other words, $-\underline{h} i$. in the $M K T Y$ should have something like the quality of a semi-vowel which is not a deflected sound. From this point of view, Ligeti's denotation $i$, which represents a central vowel, is reasonably correct but still not sufficiently inclusive to embrace all conditions mentioned above. Also, as Clauson explains: '...$-h i$ is obviously a back $i$,

25 As to the details of this term and straight sounds, see the following table:

\begin{tabular}{|c|c|c|c|c|c|}
\hline & $k^{\prime} a i \cdot k^{\prime} \circ u$ & & $-k^{\prime} o u$ & $\begin{array}{l}\text { nature of } \\
\text { vowel }\end{array}$ & $\begin{array}{l}\text { nature of } \\
\text { final }\end{array}$ \\
\hline 1 & \multirow{2}{*}{ (A) $\begin{array}{l}k a n \\
k \varepsilon n\end{array}$} & \multirow{2}{*}{ (B) } & \multirow{2}{*}{$\begin{array}{l}k w a n \\
k w \varepsilon n\end{array}$} & low and back & \multirow{2}{*}{ straight sound } \\
\hline 2 & & & & high and front & \\
\hline 3 & \multirow{2}{*}{ (C) kien } & \multirow{2}{*}{ (D) } & \multirow{2}{*}{$\begin{array}{l}\text { kxw६n } \\
\text { kiwan }\end{array}$} & central [ $\breve{\mathbf{I}}]$ & \multirow{2}{*}{$\begin{array}{l}\text { deflected sound } \\
\text { 拗意 }\end{array}$} \\
\hline 4 & & & & front [i ] & \\
\hline
\end{tabular}

The sounds which belong to the columns (A), (B), (C) and (D) are called $k$ 'ai$k^{\prime} o u-h u$ 開口呼, ho.k'ou-hu 合口烀, ch'i-ch'ih-hu 齊菌呼 and she-k'ou-hu 撮口呼 respectively.

26 According to the Han-yü Fang-yen Tzu-hui, tsay and-its group have changed to tcis in the Shuangfeng dialect and to tsiy in the Amoy dialect. The Foochow dialect also occasionally has this tendency. 
the sounds represented in the Wade transcription system by -ih (in such words as $c h i h$ ) and $\cdot \check{u}$ (in such words as $t z \breve{u}$ ); but it is hard to grasp its function in -hang.' ${ }^{27}$ This explanation is misleading, because in the $M K T Y$ - $h i$ - does not appear in any 'sound represented in the Wade transcription system by $-i h$ ' but only appears in the supradental group under the condition mentioned above. As shown in p. 52 (Chapter II, $\S 2, E, F)$, the phonetic changes of retroflex sounds since the Northern Sung period have been very complicated, but nevertheless the distinction between the supradental and affricated alveolo-palatal groups had been preserved until the early seventeenth century, although the initial consonants had already assimilated each other at that time. Even in the CYYY the supradentals in stage 3 (see p. 52 ) derived from the affricated alveolo-palatal still retained a deflected element as follows:

\section{Table 7}

\begin{tabular}{|c|c|c|c|c|}
\hline$C Y Y Y$ & $\begin{array}{c}\text { 齊 徽 韻 } \\
\text { - jei }\end{array}$ & $\begin{array}{c}\text { 支 思 頱 } \\
-\imath\end{array}$ & $\begin{array}{l}\text { Modern } \\
\text { Mandarin }\end{array}$ & $\begin{array}{c}\text { Modern } \\
\text { Wu }\end{array}$ \\
\hline$F(2 n d)$ & & 止 & \multirow{3}{*}[-1]{} & \multirow{3}{*}{$\begin{array}{c}{[-l]} \\
\text { or } \\
{[-\mathrm{y}]} \\
\text { (except } \\
\text { entering.tone) }\end{array}$} \\
\hline$F(3 r d)$ & $\begin{array}{c}\text { 蟹 } \\
\text { (entering-tone) }\end{array}$ & 止 & & \\
\hline E & $\frac{\text { 止 }}{\text { (entering-tone) }}$ & & & \\
\hline
\end{tabular}

On the other hand, in the $M K T Y$ the distinction between the supradental, affricated alveolo-palatal, and cerebral groups is as follows:

\section{Table 8}

\begin{tabular}{|c|c|c|}
\hline$M K T Y$ & $i^{\text {专 }}$ & 韻 \\
\hline$F(2 n d)$ & & $\begin{array}{l}\text { 止, 臻, 深 } \\
\text { (entering-tone) }\end{array}$ \\
\hline$F(\overline{r d})$ & $\begin{array}{c}\text { 止, 蟹 } \\
\text { (entering-tone) }\end{array}$ & \\
\hline $\mathrm{E}$ & (entering-tone) & \\
\hline
\end{tabular}

27 Clauson, op. cit., p. 320 . 
All the characters in these tables have changed to retroflex vibrant in modern Mandarin, however in both the CYYY and MKTY distinctions were still made between them on the basis of their origins in Ancient Chinese. Therefore, Clauson's explanation, ' $-h i$ is obviously. a back $-i$, the sound represented in the Wade transcription system by $-i h$ ' is completely erroneous.

Phonetically speaking, $-\underline{h} i$ should be placed somewhere near the vowels [i], [ə], [i] depending on its original vowel in Ancient Chinese. In the MKTY, the characters 士, 事, 四, 此, etc. (chih-she, 2nd-and 4th-degrees) should have a central closed vowel [x], and the characters 丽, 彭, 登, etc. (tseng-she, 1st-degree) should have a front half-closed vowel [ø].

As regards - hang, it is still difficult to infer its function as Clauson states. However, the chracters 莊, 創, 牃, 霜, etc. (supradental with a front vowel [a]) have changed to ho-k'ou in the Mandarin-speaking area despite their original nature as members of the $k^{\prime} a i-k^{\prime}$ ou group. In the $\mathrm{Wu}$ dialects they have changed to a back vowel $[\mathrm{D}]$ or $[0]$. Thus it is supposed that in the MKTY $h a$ - is used to indicate the change of [a] to the back vowels of either [u], [ $\mathrm{D}]$ or [o], therefore $h a$. may be located between them as the following diagram:
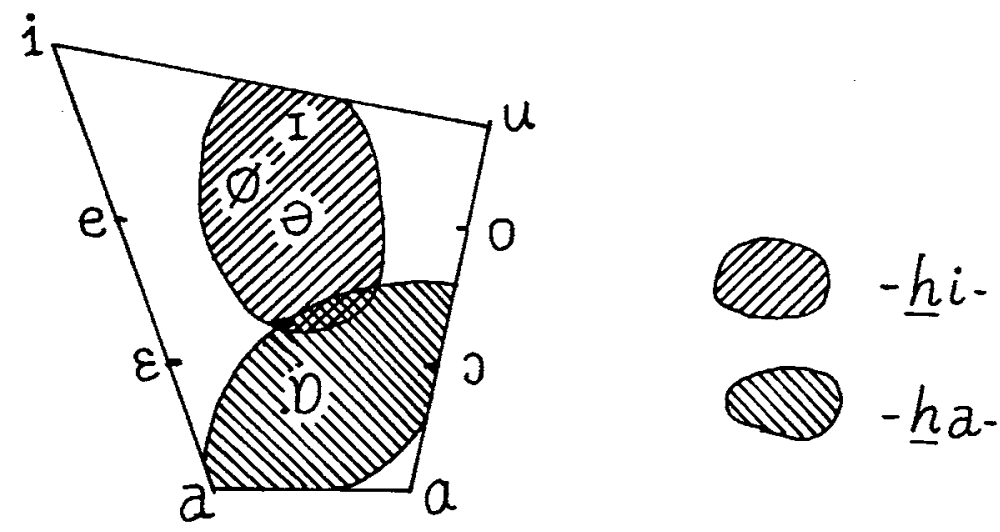
In the $M K T Y$, as shown later, there is no $[\varnothing],[\mathrm{x}]$ or $[\partial]$ as nuclei, and those vowels are very infrequent. Thus $-\underline{h}$ is supposed to be put forwards as a common medial to indicate these delicate phonetic distinctions.

From these observations, the following scheme can be deduced:

$\mathrm{AC}$

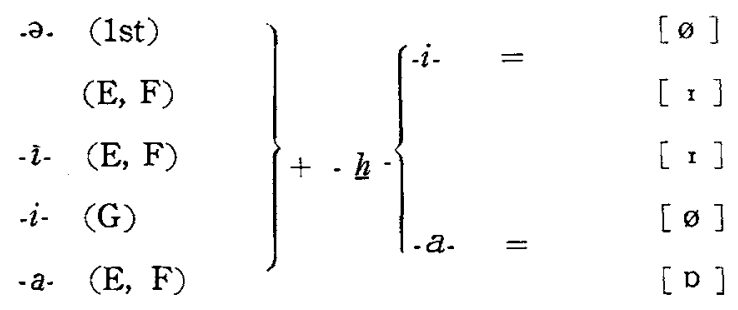

Of course, it is difficult to determine the phonetic values of $-\underline{h}$ - under the conditions mentioned above. So these three values are simply tentative, and indicate approximate quantity which might be able to satisfy some conditions.

\section{$\$ 4$ Differentiations in the Laryngeal Group}

In Ancient Chinese the laryngeal group ${ }^{28}$ is divided into the following four initials ; ying-mu 影母 $(=)$, hsiao-mu 曉 $(=h)$, hsia-mu 匣母 $(=h)$ and $y \ddot{u}$-mu 喻母 $(=j)$. On the other hand, in the Ku-chin Yün-yuiChü-yao 古今韻會擧要(abbr. $K Y C$ ) the following three initials were also added; ho$m u$ 合母, $y \ddot{u} \cdot m u$ 魯母 (to distinguish 踰母 and 魚母, the former will be called $y \ddot{u} \cdot m u 1$ and the latter will be called $y \ddot{u} \cdot m u 2$ ) and $a o-m u$ 幺; the $M K T Y$ follows this. The'Phags-pa script signs denoting these sounds are: No. 23 Г for ying-mu, No. 29 反 for hsiao-mu, No. 44 万 for hsia-mu, No. 24 $w$ for $y \ddot{u}-m u 1$, No. $36 \varangle$ for ho-mu, No. $30 \pi$ for $y \ddot{u}-m u 2$ and No. 45 $W$ for ao-mu. The conditions under which the various members of the laryngeal group are differentiated in the $M K T Y$ are as follows:

\footnotetext{
28 In this paper, the term 'laryngeal' is a translation of hou-yin 喉音 in the traditional Chinese phonology. In fact, hou.yin includes palatals $([\mathrm{j}],[\mathrm{y}])$, velars $([x],[\gamma])$, uvulars ([q], $[R])$ and laryngeals ([ ?], $[\mathrm{h}],[\hat{h}])$ phonetically. There. fore the term 'laryngeal' in this paper follows the traditional Chinese terminology.
} 


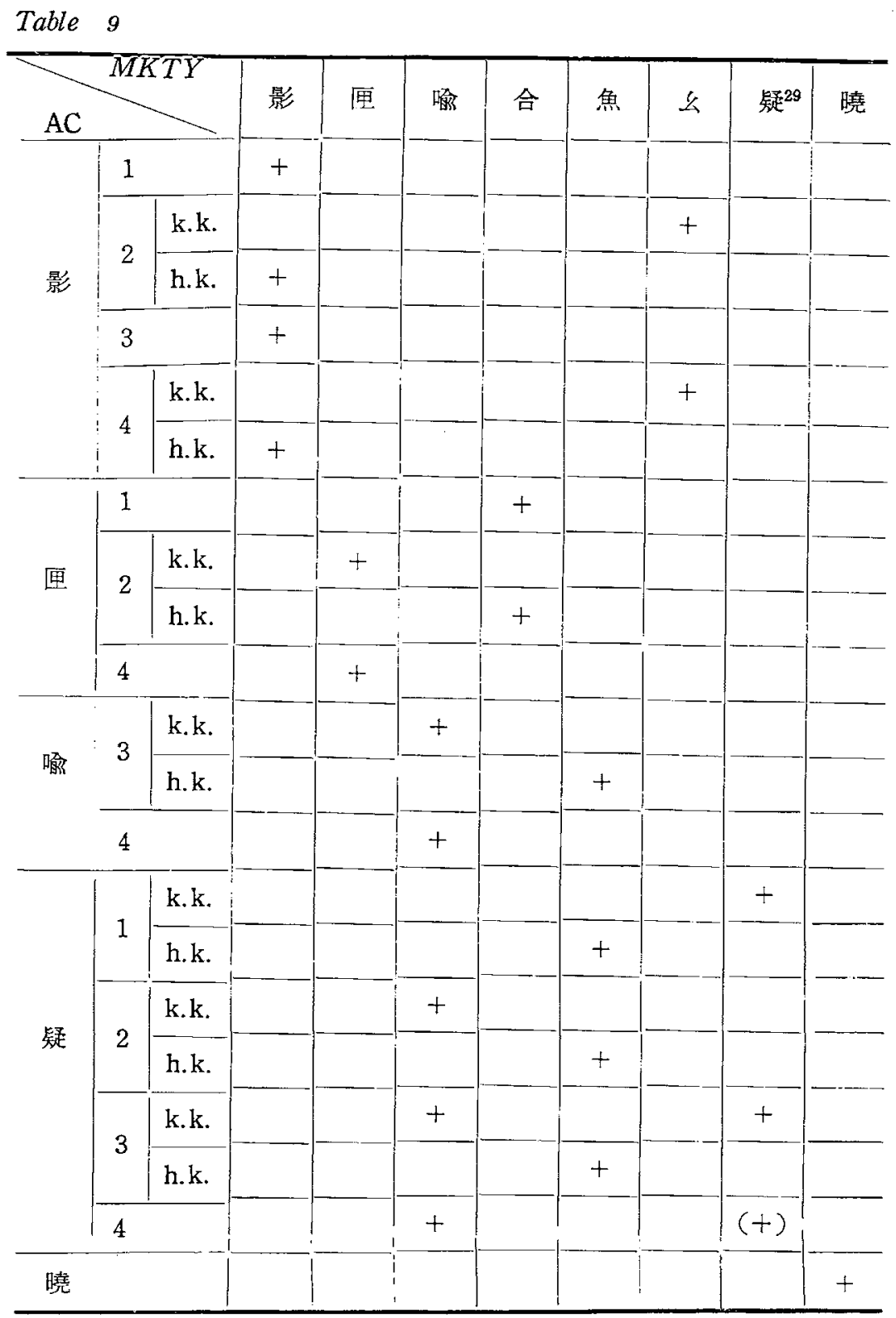

29 In this table, the column of $i-m u$ is insufficient because this initial still retains its original nature in Ancient Chinese under the condition of $k, k$. of 1,3 and 4 degrees. 
Hattori puts forwards as the actual phonetic values of these seven initials the following: ${ }^{30}$

$$
\begin{aligned}
& \text { - : ying-mu [?] } \\
& y: a o-m u \quad\left[?_{j}\right] \\
& \text {, : } y \ddot{u}-m u 2 \text { (gradual beginning of voice) } \\
& j: y \ddot{i} \text {-mu } 1 \text { [j] } \\
& h: h s i a o-m u \text { [h] } \\
& \gamma: \text { ho-mu }[\gamma] \\
& \text { ह: hsia-mu [6] }
\end{aligned}
$$

adding by way of justifications :

According to the established theory of Chinese phonology, this is the only way to infer the sounds. On the other hand, comparison with a Tibetan sound represented by the Tibetan letter ' $a(=e)$ and a Mongolian sound represented by a 'Phags-pa sign equivalent to this Tibetan chaoacter, suggests that it is better to take [ ] for', and, as the gradual beginning of voice'. Dragunov, in his article 'The hPhags-pa script and Ancient Mandarin', also takes the Chinese sounds represented by these 'Phags-pa signs as follows:

$$
\begin{aligned}
& \because[2] \\
& \because:[\mathrm{h}] \\
& \mathrm{j}:[\mathrm{j}]
\end{aligned}
$$

Dragunov does not explain his reasons, although he notices that the Tibetan sounds representing the first two are $[h]$ and [?] being exactly opposite to each other. I shall attempt to explain this difficulty by pointing out that in Mongolian documents in 'Phags-pa script, the initial vowels are represented either with an initial consonant, (and vowel) or a special vowel as follows:

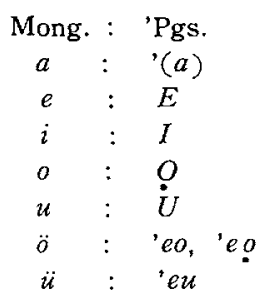

In exceptional cases, the letter $\mathrm{e}$ is rarely used like $\mathrm{i}$-he-sen and e eu-gu-le. The reason why the initial, is more frequently used than - is not due to the fact that the Mongolian initial vowel begins with clear [?], but is caused by the fact that in Tibetan, is more frequently used than e as an initial vowel. If it may be supposed that in Mongolian the initial vowels are always preceded by [?] as a phoneme, the letter, is probably used to represent the phoneme [?]. The Chinese might have regarded, which is the gradual beginning of voice in Mongolian initial

30 Hattori, op. cit., pp. 50-2,71-2(n.18). 
vowels as the same as $y \ddot{u}-m u 2$, and also identify the initial [j] with $y \ddot{u}-m u 1$. Thus they may have adopted an initial e to represent ying-mu and invented an initial $y$ which is derived from the 'Phags-pa $j$ to represent ao-mu. ${ }^{31}$

As far as the 'Phags-pa Mongolian documents are concerned, Hattori's theory corresponds exactly to the result of Poppe's investigations ${ }^{32}$; however, we still need to consider the ascription in the $K Y C$ to clarify the phonetic value in Chinese documents. The $K Y C$ denotes these sounds as follows :

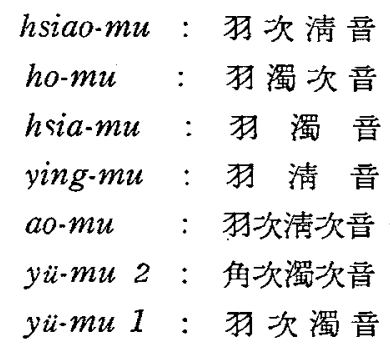

Namely, the terms $y \ddot{u}$ 炣 and chiao 角 correspond to hou-yin 嗼音 (=laryngeals) and ya-yin 牙亘 (=velars) in the Yün-ching 㽬鏡 system. ${ }^{33} T z^{\prime} u$ ch'ing.yin 次清吾, cho-yin 濁夏, ch'ing-yin 满音 and $t z^{\prime} u$-cho-yin 次濁晋 mean voiceless aspirated initials, voiced initials, voiceless non-aspirated initials and voiced nasal initials respectively. The function of $t z^{\prime} u$-yin 次音, however has not yet been clearly worked out.

According to Chang Fu's 章料 Ch'i-yin san-shih-liu-mu fan-ch'ieh ting. $c h \ddot{u}$ 七音三十六母反切定局 ${ }^{34}$ based on the $K u$-chin Yün-hui古今䫓會 (abbr. $\left.K Y\right)$, $t z^{\prime} u$-yin occurs only in the $h \sin -m u$ 心母, shen-mu 審母 and $c h^{\prime} a n-m u$ 禪母; i.e. as far as Chang Fu's table is concerned, $t z^{\prime} u \cdot y i n$ means a fricative element.

On the other hand, phonetically speaking, $[\mathrm{f}, \mathrm{v}, \mathrm{s}, z, \mathrm{~s}, z, \mathrm{x}, \gamma, \mathrm{h}$, hi] belong to the fricative sound group. The $K Y$ mentions that fei-mu 非母, $f u-m u$ 敷母 and feng-mu 奉母 which were derived from the bilabial plosives belong to tz'u-kung ch'ing-yin 次宮清音, t'zu-kung

31 Ibid., pp. 71-2.

32 Poppe, op. cit, pp. 19-24.

33 As regards the terms $y \ddot{u}$ 炣, chiao 角, kung 宮, chih 徵 and shang 商, see the following books: Wang Li, Han-yü Yin-yün-hsüeh, pp. 56-77; Chao Yin-t'ang, Teng-yün Yüan-liu, pp. 10-15, 53-4, 77,110, 141-2, ; etc.

34 For detail on this table, see Chao Yin-t'ang, ibid., pp. 139-142. 
$t z^{\prime} u$-ch'ing-yin 次宮次清晋 and tz'u-kung cho-yin 次宮濁音 which mean labio-dental voiceless non-aspirated, labio-dental voiceless aspirated and labio-dental voiced respectively. In this classification, these labio-dentals which came into existence in the eleventh century in China were classified as $t z^{\prime} u$-kung 次宮 or semi-labials (=labio-dentals), therefore they were not put into the tz'u-yin group. Also in Chang Fu's classification, hsieh-mu 邪母 should be included in the $t z^{\prime} u-y i n$ although he also included it amongst $t z^{\prime} u$-cho-yin (=voiced nasals) by mistake. The sounds $[h, f]$, according to Pike, should be classified into the 'vocoid'; i. e. fricatives like $[h, f]$ or semi-vowels $[j, w]$ which are the sounds 'which air leaves the mouth over the centre of the tongue (non-lateral) and without friction in the mouth (but friction elsewhere does not affect the classification).' 35

It is not surprising that Huang Kung-shao 黃公紹, the compiler of the $K Y$, noticed the peculiar nature of the fricative $[h, f]$ as vocoid and put them into the ordinary group. Thus we can explain the three initials in the $K Y C$ by using the concept of $t z^{\prime} u$-yin (=fricative element) as follows :

$$
\begin{aligned}
& \text { ying-mu : [?] = glottal voiceless (可清) } \\
& \text { hsiao-mu : [h] = glottal voiceless aspirated (炣次清) } \\
& \text { ao-mu : }[\mathrm{x}]=\text { velar voiceless aspirated fricative（狂次清次音） } \\
& \text { hsia-mu : [6]=glottal voiced (犽濁) } \\
& \text { ho-mu : }[\gamma]=\text { velar voiced fricative (㹦滥次音) } \\
& \text { yü-mu } 1 \text { : [j]=palatal voiced semi-vowel } k^{\prime} a i-k^{\prime} \text { ou (炣次濁) } \\
& y u ̈-m u 2 \text { : [u]= palatal voiced semi-vowel ho-k'ou (炣次濁次亘) }
\end{aligned}
$$

According to this hypothesis, [x] for ao-mu could be passively denoted $\left[?_{\mathbf{j}}\right]$, as Hattori infers; however, the combination of the glottal stop [?] and palated semi-vowel $[j]$ may be expected to produce the aspirated fricative sound $[x]$ which appears slightly front of the glottal voiceless aspirated [h]. Also unless otherwise indicated the glottal stop [?] occurs before $[j]$, this sound being very similar to yü-mu $1(=[j])$, and this is probably the reason why this letter No. 45, whose shape is slightly

35 K. L. Pike, Phonetics, A Critical Analysis of Phonetic Theory and a Technic for the Practical Description of Sounds (=Language and Literature, XXI) (Ann 
different but still easily mixed up with $y \ddot{u}$-mu 1 (No. 24), was later invented. From these facts, we may conclude firstly that Huang Kungshao distinguishes ao-mu from its original initial ying.mu, and secondly that he mentions this actual sound as similar to hsiao-mu by its aspiration, thirdly that Chu Tsung-wen, compiler of the MKTY, probably noticed the similarity between $a \sigma^{-m u}$ and $y \ddot{u}$ - $m u 1$ by virtue of their both including a semi-vowel $[j]$, and therefore invented a new letter to represent this sound by changing the shape of $y \ddot{u}-m u 1$. The ao-mu gives us many difficulties, i.e. its origin, denotation in the $K Y C$, and the shape of the letter used to denote it in the 'Phags-pa script. I can thus only offer a hypothetical equivalent for this sound. According to the description in the $K Y C$ the phonetic value of this initial should be [x] although Hattori's assumption is more realistic. As regards transcription of this letter, it is adequate to adopt $y$ as Hattori, Clauson, and Denlinger do. ${ }^{36}$ However the transcription $\cdot j$ may be better to distinguish it from the gradual beginning of voice $j$ ( $y \ddot{u}$-mu 1) because $y$ is easily mixed up with the phoneme [y]. As far as $y \ddot{u}$-mu 2 is concerned, my assumption of the phonetic value of this letter [ $]$ may be reasonably correct because this initial is derived from the ho-k'ou of $y \ddot{u}-m u 1$ and $i$-mu 疑母 in Ancient Chinese. For the transcription of this letter, $y$ will certainly be better than Hattori's , or Oshibuchi and Poppe's $a$.

Thus we can conclude that the transcription and phonetic value of these letters should be as follows: ${ }^{37}$

$\begin{array}{lcc}\text { initial : } & \text { transcription } & \text { phonetic value } \\ \text { ying-mu: } & \cdot & {[?]} \\ \text { hsiao-mu: } & h & {[\mathrm{~h}]} \\ \text { ao-mu : } & \cdot j & {[\mathrm{x}]} \\ \text { hsia-mu : } & h & {[\mathrm{G}]} \\ \text { ho-mu : } & \gamma & {[\gamma]} \\ \text { yü-mu 1: } & j & {[\mathrm{j}]} \\ \text { yü-mu 2: } & y & {[\mathrm{y}]}\end{array}$

\footnotetext{
Arbor: University of Michigan Publications, 1947, 3rd. ed.), pp. 76-8.

36 Clauson, op. cit., pp. 322, No. 24A ; Denlinger, op. cit., pp. 415 (No. 33a), 424. Besides the Chinese characters 压 (32), 影 (33a), 喻 (34) and 以 (34a) in Denlinger's Chart Ia should be corrected to 合, 玄, 魚 and 喻 respectively.

37 Cheng Tsai-fa also gives a full account of the laryngeal group in the MKTY in comparison with the $K Y C$. He deals in great detail with fan.ch'ieh of this group, but it is regrettable that he gives no actual phonetic value of each letter. See MKTY ken ken Pa-suu-pa-tzu yu-kuan-te yïn-shu, (Taipei, 1965), pp. 27-35.
} 


\section{IV \\ THE SOUND SYSTEM IN THE \\ $M E N G-K U$ TZU.YÜN}

\section{§1. On the Meng-ku Tzu-yün}

The $M K T Y$ ( 2 vols. ) is said to have been compiled by Chu Tsungwen in the first year of the Chih-ta 至大 reign (1308). ${ }^{1}$ According to the $S s u-k^{\prime} u C h^{\prime} u ̈ a n-s h u$ Tsung-mu $T^{\prime} i-y a o$ 四庫全書總目提要, Chu Tsung-wen was one of the students in the Meng-ku Tzu-hsueh ( $=$ 'School for the Mongolian Script') established by Imperial edict in each province after the invention of the 'Phags-pa script. ${ }^{2}$ Liu Keng 劉更 states in his preface to the $M K T Y$ that Chu Tsung-wen's Mongolian name is Po-yen 伯 頝 or Pa-yen 巴顔 (Mong. Bayan) which means 'rich' or 'wealthy'.

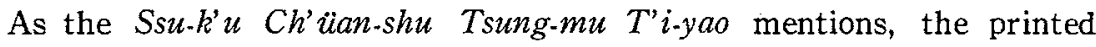
text of the $M K T Y$ has long been lost, and today the manuscript held in the British Museum is believed to be the only reliable text. ${ }^{3}$ Based upon this manuscript, the following editions are now available:

1. Eiin Daiei Hakubutsukan zō Kyūshōhon Mōko Jiin, 2 vols. 影印大 英博物館藏萑鈔本蒙古字韻二觉. This is based on the photos taken by J. Ishihama 石濱純太郎 in 1921.

1 According to Liu Keng's preface to the $M K T Y$, Chu Tsung-wen ( $t z u$, Yen-chang 彥章) simply revised and enlarged the original text of the $M K T Y$, which has been lost. The original text of the $M K T Y$ is supposed to have had at least two editions ; the Hupeh edition and the Chekiang edition. See Chu Tsung-wen's preface to the MKTY (Kansai Daigaku edition, pp. 5-6; PSPT edition, p. 96); Cheng Tsai-fa, op.cit., pp. 3-7.

2 The $T^{\prime} i-y a 0$ also states that Chu Tsung-wen was born during the Chih-cheng 至正 reign (1341-1368), but this should be corrected to the Chih-yüan 至元 reign (12641294), because the year in which Chu Tsung-wen compiled the $M K T Y$ was the year of wu-shen in the Chih-ta 至大 reign (1308). See Ts'ai Mei-piao, PSPT, p. 89 ; Cheng Tsai-fa, op. cit. p. 5. Liu Keng is said to have been a teacher of Chu Tsung. wen in the Meng-ku Tzu-hsüeh, but there are no reference to this man.

3 The manuscript of the $M K T Y$ held in the British Museum is supposed to have been copied in the Ch'ien-lung 乾隆 reign (1736-1795) of the Ch'ing dynasty (see Y. Ozaki, 'Daiei Hakubutsukan-bon Mōkojiin sakki', p. 164). This manuscript was bought by Mrs Russell in 1909 (6 April) (see Lo Ch'ang-p'ei, 'MKTY pa', PSPT, 
2. Hsieh-pen Meng-ku Tzu-yün 易本蒙古字韻 in the PSPT. This is based on the photos taken by Yü Tao-ch'üan 于道泉 in 1938.

The MKTY consists of a title page, a preface by Liu Keng, the compiler's preface, a list of errata in each edition, a diagram of Tsung- $k^{\prime}$ uo Pien-hua chih t' $u$ 總括變化之圖, a table of the 'Phags-pa alphabet, a table of the 'Phags-pa alphabet in seal-script form, a table of contents, the text (vol. 1, pp. 8a-33b; vol. 2, pp. la-30a, the PSPT edition lacks pp. 5a-b, both lack pp. 31a-b) and colophon.

The MKTY was, as Chu Tsung-wen states in his preface, based upon the $K Y$ whose text has been lost. The sound system employed in the $K Y$ is, therefore, still a matter of conjecture. However, according to the Ssuk'u Ch' üan-shu Tsung-mu T'i-yao, Huang Kung-shao 黃公紹, who composed the $K Y$, was born in Chaowu 昭武 in Foochow and became a chin-shih 進士 (a top-class successful applicant for bureaucracy examination) in the first year of the Hsien-ch'un 咸淳 reign (1265) in the Sung dynasty, and never held a post under the Yüan government. ${ }^{4}$ He is therefore believed to have been hostile to the Yiian government, and it is also supposed that he did not recognise the dialect of Ta-tu 大都 (the capital of the Yüan dynasty, Peking) as standard Chinese but took a dialect of either Pien-ching 泫京 (the capital of the Northern Sung dynasty, Kaifeng) or Lin-an 臨安 (the capital of the Southern Sung dynasty, Hangchow) as standard Chinese. ${ }^{5}$ Moreover, Hsiung Chung 熊忠, the compiler of the KYC which is a reduced edition of the $K Y$, was also born in Chaowu, while Chu Tsung-wen, the compiler of the MKTY was born in Hsin-an 信安 (Kiuchow) in Chekiang province. ${ }^{6}$ It is noteworthy that none of these three compilers was born in Peking or anywhere else in Northern China, and it therefore seems extremely unlikely that these books would have employed sound system of the Northern or Mandarin-speaking area. Only Chu Tsung-wen is

p. 84). The catalogue number of this manuscript in the British Museum is OR. 6972.

4 The T"i-yao makes no mention of the Ku-chin Yün-hui, but it gives an account of the Tsai-hsiian chi 在軒集, Huang Kung-chao's prose selection.

5 For further details, see Hattori, op. cit., pp. 39-40, 54-6.

6 There were two Hsin-an prefectures in the Yijan dynasty, one in Hopei province and the other in Chekiang province. In the case of Chu Tsung-wen, Hsin-an was 
generally said to have been appointed to the Yüan government.

Nevertheless, a satisfactory conclusion on the sound system employed in these books cannot be deduced unless we study them phonologically.

In this chapter, I intend to analyse the $M K T Y$ phonologically regardless of whether the sound system employed in the $M K T Y$ is identical with that in the $K Y$ (or $K Y C$ ) or not.

\section{$\S$ 2. Initial Consonantal System}

\section{(1) Voiced Initials}

The most distinctive peculiarity in the initial consonantal system of the MKTY is the existence of voiced initials. In the CYYY compiled almost at the same time as the $M K T Y$, voiced initials in Ancient Chinese were assimilated into either voiceless aspirated or voiceless non-aspirated depending on their tones.

Amongst modern dialects, only the $\mathrm{Wu}$ and Amoy dialects ${ }^{7}$ have still retained voiced initials. In the Mandarin-speaking area, the disappearance of voiced initials begins in the eleventh century. The earliest indication of their disappearance may be seen in the HCCS compiled by Shao Yung. Thus, the existence of voiced initials in the MKTY suggests a possibility that the sound system there employed is related to either the Wu or the Amoy dialects. Further difficulties involved by the assumption or the reconstruction of the old sound system will be discussed in $\S 5$ of this chapter.

(2) Changes of $i-m$ 疑母 ( $(y)$

In the $C Y Y Y$, very few characters retain their original initial $y$; all the others have devocalised or have been assimilated either to $y \ddot{z}$ $m u$ or to hiao-mu. ${ }^{8}$

On the other hand, in the $M K T Y$, the distribution of the initial $y$ is very complicated, as shown below:

probably in Chekiang province because the $T$ ' $i-y a o$ calls him 'a man from the South'. See Cheng Tsai-fa, op. cit., p. 13, n. 9.

7 See Lo Ch'ang-p'ei, Hsia.men Yin.hsi, (2nd ed.). pp. 5-9.

8 Lo Ch'ang-p'ei states that there is no distinction between $i-m u, y u-m u$ and $h$ siao. $m u$ in the CYYY ('CYYY sheng-lei k'ao' $A S$, II, 4 (1932), pp. 423-40), but as Chao Yin-t'ang infers only the characters which belong to kuo-she 果攝 retained their ori- 


\section{Scheme 1}

$$
\begin{gathered}
\mathrm{AC} \quad M K T Y \\
k^{\prime} a i-k^{\prime} \circ u\left\{\begin{array}{l}
1 \\
3 \\
2 \\
4
\end{array}\right\} \longrightarrow \text { i.mu }(y) \\
\text { ho. } k^{\prime} \text { ou }\left\{\begin{array}{l}
1 \\
2 \\
3
\end{array}\right\} \longrightarrow \text { yü-mu 1(j) }
\end{gathered}
$$

According to Chao's investigation, in most of the $\mathrm{Wu}$ dialects the initial $\mathfrak{V}$ has been kept when preceded by a straight final, and has changed to either $n$ or $\hat{n}$ when preceded by a deflected final. ${ }^{9}$ On the other hand, in the MKTY $y$ disappeared when preceded by the $h o-k^{\prime} o$ finals. Thus the distribution of $y$ in the $\mathrm{Wu}$ dialects and the $M K T Y$ is very dissimilar. However, in Hangchow (previously Linan), $y$ has been kept only when it follows the straight final of $k^{\prime} a i \cdot k^{\prime} o u$ and changed to $h(u)$ when preceded by the straight final of ho-k'ou. Also following the deflected sounds, $y$ has changed to either $n$ or $j$. This distribution again is different from that in the $M K T Y$, because the MKTY retains $\eta$ when preceded by $k^{\prime} a i \cdot k^{\prime}$ ou of 3rd-degree final. However, it is possible that $y$ in this may have disappeared at some time since the MKTY was compiled. The following scheme shows the distribution of $y$ in Hangchow in contrast to Scheme 1.

Scheme 2

$$
\begin{aligned}
& \text { AC Hangchow } \\
& k^{\prime} a i-k^{\prime} \text { ou }\left\{\begin{array}{l}
1 \\
2 \\
3 \\
4
\end{array}\right\} \longrightarrow n \text { or } j \\
& h o-k \text { ou }\left\{\begin{array}{l}
1-\longrightarrow \\
2 \\
3
\end{array}\right\} \longrightarrow h(u)
\end{aligned}
$$

Comparing Scheme 1 and 2, the change from 1 to 2 is phonologically

ginal initial in the $C Y Y Y$ [CYYY Yen-chiu (Shanghai, 1936), chapter III]. I Fu also maintains that many characters of the $i-m u$ group retain their initial $y$ in the $C Y Y Y$ ( 'CYYY 25 sheng-mu chi-shuo' $Z Y, 132$ (1964), pp. 337-59).

9 Hsien-tai Wu-yui te Yen-chiu, pp. 23-4, 31. 
natural, because $y$ belonging to the 3rd-degree of $k^{\prime} a i-k^{\prime}$ ou in Scheme 1 has an ability to change to $n$ or $j$, and the devocalised sounds in Scheme 2 can easily be accompanied by $h$ if pronounced with strong aspiration. Thus the distribution of the initial $y$ in both the $M K T Y$ and Hangchow dialect is quite similar. However, it cannot be concluded that the sound system employed in the $M K T Y$ is the Hangchow dialect without having investigated certain other elements. So far we are only entitled to assume that as far as the initial $y$ is concerned the sound system employed in the MKTY may be the Hangchow dialect.

(3) Crianges of niang-mu 娘母 ( $(\tilde{n})$

In the CYYY, niang-mu (palatal nasal $\tilde{n}_{-}$) was assimilated to $n i$ $m u$ 泥 $(n)$. In the $M K T Y$, this initial has almost retained its original nature although there were some confusions between this initial and $n i-m u$ and $j i h-m u$ as Table 10 shows:

This phenomenon can be also seen in Archaic Chinese, as Chang $\mathrm{P}^{\prime}$ ing-lin proposes. ${ }^{10}$ In the Mandarin-speaking area, as seen in the $C Y$. $Y Y, n i-m u$ and $j i h-m u$ are obviously distinguished as a dental plosive nasal and a retroflex vibrant respectively. In most $\mathrm{Wu}$ dialects, on the other hand, these three initials are confused. As already discus. sed, the initial $j i h \cdot m u$ presents some difficulties, but on the assumption that the phonetic value of this ancient sound was $\not \dot{z}$ as Karlgren proposes, in the Wu dialects 'the written form has adopted its fricative element to produce the same sound as ch'uang-mu and $c h$ 'an-mu 瀷母 and the spoken sound has adopted its nasal element to produce something similar to ni-mu and niang-mu.' ${ }^{11}$ However, in the MKTY the $j i h-m u$ initial exists as an independent initial, therefore 'the sound system employed in the MKTY does not accord with the spoken sound in the $\mathrm{Wu}$ dialects, because $z$ was supposed to represent the voiced alveolar fricative and not a nasal as is evident by the Tibetan prototype of this letter.' 12 Nevertheless, on the assumption that the $M K T Y$

10 'Ku-yin niang, jih erh-niu kuei ni shuo', Chang-shih Ts'ung-shu, vol. I, pp. 30b-33a.

11 Chao Yuen-ren, op. cit., p. $29 . \quad 12$ Hattori, op. cit., p. 52. 


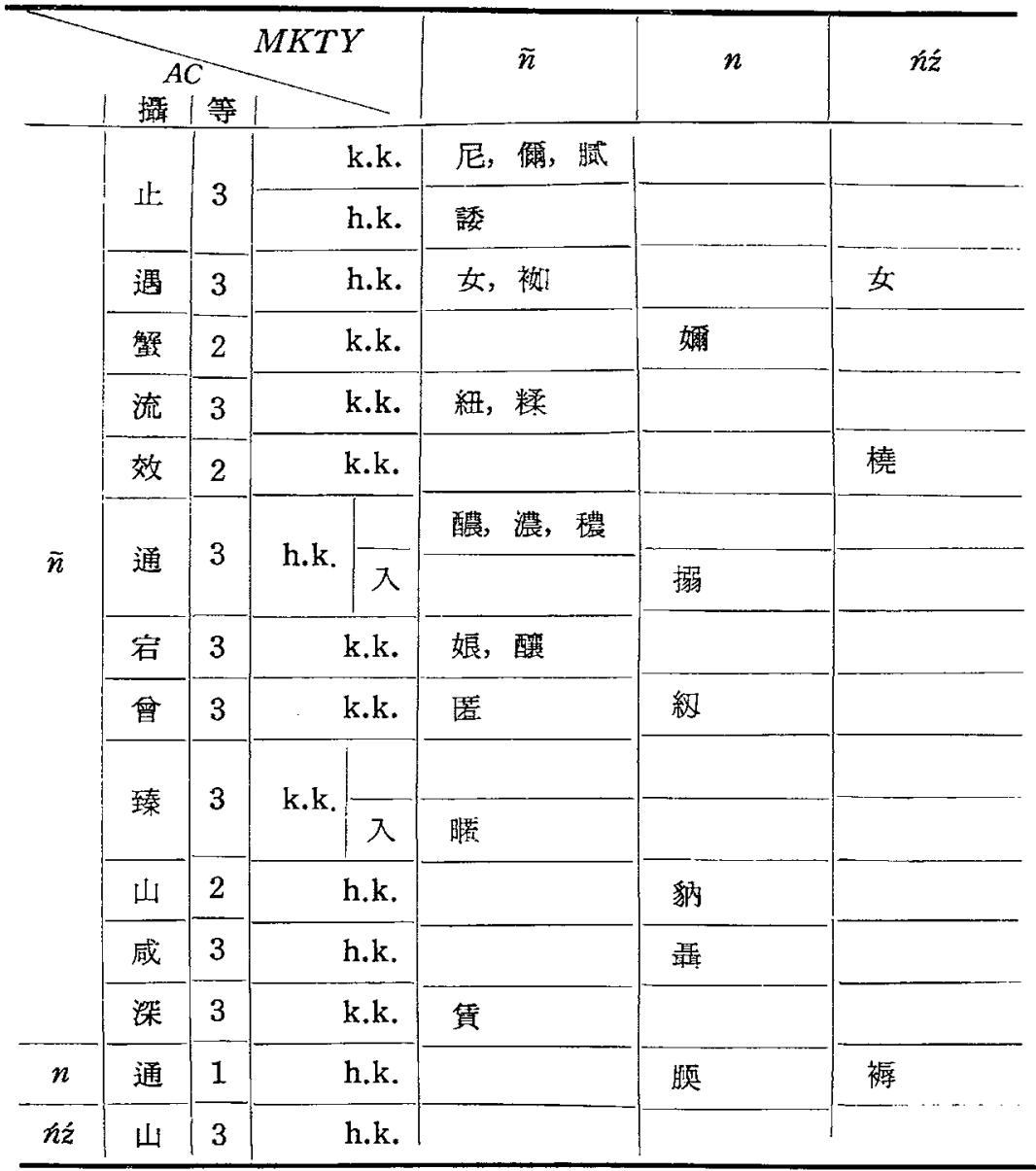

confuses the spoken and literary forms of the Wu dialects, the con. fusion between niang-mu, ni-mu, and jih-mu and the existence of a voiced alveolar fricative can be understood without difficulty.

(4) On the treatment of labio-dentals

The treatment of the labio-dental group in the $K Y C$ and $M K T Y$ can be said to be conservative or showing a tendency to archaise. The $K Y C$ distinguishes even $f e i$-mu 非好 and $f u-m u$ 數母, although the $M K T Y$ correctly unified them as only one phoneme $f$. The existence of 
feng-mu 奉母 $(v)$ in the $M K T Y$ can be said to be a consequence of the $M K T Y$ 's retention of voiced initials. Only one problem concerning the treatment of wei-mu 微母 $(w)$ in the $M K T Y$ requires comment. Initial wei-mu was derived from ming-mu 明母 of the 3rd-degree under the following conditions:

Table 11

\begin{tabular}{|c|c|c|}
\hline 攝 & $k^{\prime} a i$ or ho & \\
\hline 通, 曾, 梗, 流, 效 & & \multirow[t]{2}{*}{$m$} \\
\hline \multirow{2}{*}{ 此*,山，臻 } & k.k. & \\
\hline & h.k. & \multirow{2}{*}{$w$} \\
\hline 宕, 遇, 成 & & \\
\hline
\end{tabular}

(*with a few exceptions)

However, in the MKTY this initial is confused with ming-mu as follows :

Table

12

\begin{tabular}{|c|c|c|}
\hline $\mathrm{AC}_{\mathrm{AC}}^{M K T Y}$ & $m$ & $w$ \\
\hline$m$ & $\begin{array}{l}\text { (A) } \\
\text { 蒴, 謾, etc. }\end{array}$ & $\begin{array}{l}\text { (B) } \\
\text { 夢, 目, 繆, 牧, 矛, } \\
\text { 謀, 牛, etc. }\end{array}$ \\
\hline$w$ & (C) 曼 & 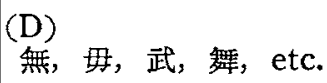 \\
\hline
\end{tabular}

In Table 12, the columns (B) and (C) show confusions between $m i n g \cdot m u$ and wei-mu. In the Hangchow dialect, the spoken sound of $w e i-m u$ has two initials $m$ and $v$. In the Shanghai dialect also the literary sound of wei-mu has two initials $\beta$ and $v$ (or $h(u)$ ), ${ }^{13}$ but the differentiating features of these initials in the $W u$ dialects are not the same as those in the MKTY.' According to Chou Tsu-mo, in the HCCS the initial wei-mu is divided into two sounds $m$ and $v$ depending on its tones; in the case of falling-rising-tone wei-mu changes to either zero or $v$, in the case of the other tones (=level-tone, falling-tone and entering-tone) it changes to $m .{ }^{14}$ The sound system employed in the HCCS is supposed to be the Pien-ching (Kaifeng) dialect of that

13 See Chao Yuen-ren, op. cit., p. 22.

14 'Sung-tai Pien-Lo yü-yin k'ao', FJHC, XXII, 1-2 (1943), pp. 268-9. 
day. If Hattori's hypothesis is correct, the sound system employed in the MKTY is the Pien-ching dialect transplanted to Lin-an by the transfer of the capital, and thus the confusions in the HCCS and $M K T Y$ should be similar to each other. Thus as far as the confusion between wei-mu and ming-mu in the MKTY is concerned, there is little possibility that this sound system is related to one of the $\mathrm{Wu}$ dialects or even to the Pien-ching dialect. This problem clearly requires further investigation.

(5) On the distribution of the retroflex initials

It is still difficult to establish the sound system in the MKTY on the evidence mentioned above, but in part at least it presents similarities to one of the $\mathrm{Wu}$ dialects. Nevertheless, another difficulty arises here which requires clarification; this is the problem of the existence of retroffex initials.

As is well-known, the retroflex initials in the modern Mandarinspeaking area have come from the supradental, affricated alveolopalatal and cerebral, and the development of these initials from old Mandarin has been very complicated, as shown in p. 52 above.

In the $M K T Y$, it is obvious that the retroflex initials in the modern Mandarin are clearly distinguished from other dental initials. On the other hand, in the $\mathrm{Wu}$ dialects, as already discussed (Chapter II, $\S 2, E, F$ ), they have been assimilated to the simple sibilant group with the exceptions of the Kiuchow 䧳州 and Kinhwa 金華 dialects. Kiuchow was previously called Hsin-an 信安, and was Chu Tsung-wen's birthplace. Although it is not certain whether Chu Tsung-wen referred to his own dialect or not, or whether the other Wu dialects had already assimilated the groups $E$ and $F$ to the sibilant group or not, the existence of the $t$ s series may be regarded as the result of Mandarin element. 


\section{§ 3. Final System}

(1) 15 final groups in the $M K T Y$

In the $M K T Y$. all the finals are classified into 15 groups as follows :

1. tung-yün 東韻: -ung, eung.

2. keng-yün 庆䫕： -ing, -hing, -iung, -eing, -üung,

-iing.

3. yang-yün 陽韻: -ang, -̌ang, -ŭang, - hang, -ong,

-üeng.

4. chih-yün 支韻: $\quad-i, \quad-h i, \quad-e i, \quad-u \varepsilon, \quad-i u \varepsilon, \quad-e u \varepsilon, \quad-\breve{u} i$.

5. $y \ddot{u}-y \ddot{u}$ 魚暗: $-u,-e u$.

6. chia-yün 佳䫓: $\quad-a j, \quad-\breve{u} a j, \quad-\check{\imath} a j, \quad-\underline{h} i j, \quad-i j$.

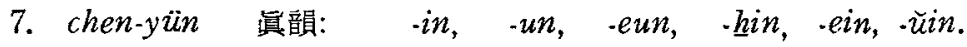

8. han-yün 寒韻: an, -on, - ǔan, -ĩan.

9. hsien-yün 先韻: -En, -en, -ǔen, -eon -ǐnn.

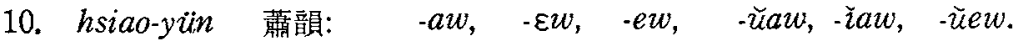

11. $y u-y u ̈ n$ 尤韻: $-i w,-u w,-h i w,-e i w,-o w$.

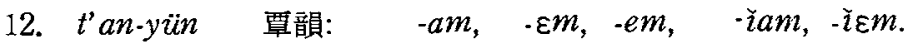

13. ch'in-yün 浸韻: -im, - him, -iim.

14. ko-yün 歌韻: $\quad-o, \quad-\breve{u} o$.

15. ma-yün 麻韻: $\quad-e, \quad-\breve{u} a, \quad-\check{\imath} a, \quad-\breve{u} e, \quad-\breve{u} \varepsilon,(-a,-\varepsilon)$.

Some peculiarities of the final system in the MKTY will be discussed below.

(2) $-e u$ - and $-\check{\imath} u-15$

In the 'Phags-pa Mongolian documents, $\bar{\sigma}(e u)$ represents the sound $[\mathrm{y}]$. In the 'Phags-pa Chinese documents, this compound of $e+$ $u$ also appears very frequently. Dragunov denotes this compound as $\dot{e} u$ and infers its Chinese phonetic yalue as $[\mathrm{y}]^{16}$ Ligeti gives the Chinese phonetic value of this compound as $\ddot{u}([y]),{ }^{17}$ as in Mongolian.

15 In my previous article, I corrected all the $e u$. greup to $-i u$, but in the present paper I keep the 'Phags-pa spelling.

16 'The $h$ Phags-pa script and Ancient Mandarin' (Chin. tr.), pp. 26-9.

17 'Le Pokia sing...', e.g. Index Nos. 287-309. 
In Ancient Chinese, - $\check{i} w$ - and -ǐ $u$ - did not have a central vowel [y], although the Uighur script tended to transcribe Ancient Chinese $-\check{\imath} w$ - and $-\grave{i} u$ - as $-\ddot{u}-.18$

Yet it is very difficult to decide whether in Old Mandarin -iw-and -ǐu- had changed to $[\mathrm{y}]$ or not. Chao Yin-t'ang infers that in the $C Y Y Y$ there was a sound $[y]$, such as in 容 $y n g$, 從 $t$ syng, 局 $t c y$, etc. ${ }^{19}$ Chao's denotation has been adopted by E. Nagashima, ${ }^{20}$ but the characters which include Chao's yng are -ung in modern Pekinese, with the exception of 兄, 凶, 雄, 熊, etc, which are now denoted as hsiung (or hsüng) in the Wade transcription. It would have been very unnatural for Ancient Chinese -iung to have changed to yng and for $y n g$ to have changed to -ung. In the CYYY, therefore, Chao's $y$ should be corrected to $\tilde{\imath} o$ or $\tilde{\imath} u_{*}^{21}$

But the question remains, when did -iu change to $y$ ? In the Hsi-ju Erh-mu-tzu 西需耳目資 (1626) by Nicolas Trigault, characters such as 中, 弓, 松, 龍, which were considered as -io in the CYYY are romanised as chum, kum, sum, lum ${ }^{22}$ respectively. So it can be seen that the sound -iong of the $C Y Y Y$ had already lost its deflected element $-i$ - (or $-j_{-}$) as a medial at the latest by the seventeenth century. On the other hand, the Hsi-ju Erh-mu-tzu distinguishes characters such as 於, 居, 須, 虛, 魚, which were derived from the yin-lei group from 曲, 菊, 欲, 局, which were derived from the Ancient Chinese entering-tone denoting the former group as $-i u$ and the latter group as io. The phonetic value of Trigault's $-i u$ must be $[y]{ }^{23}$ The Shansi dialect, the sound system employed in his book, replaced the final consonants $-k$,

18 Cf. Csongor, 'Chinese in the Uighur script ...', e.g. Index Nos. 29 癸 $k \ddot{u}, 51$ 慧

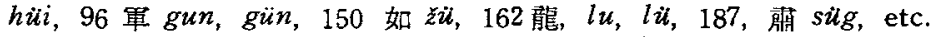

19 CYYY Yen-chiu, p. $104 \mathrm{ff}$.

20 Nagashima, 'Kinsei Shinago tokuni Hoppõgo keitō ni okeru on'inshi kenkyū shiryō ni tsuite', $G K, 7-8$ (1941), pp. 155-8.

${ }^{21}$ Cf. Lu Chih-wei, 'Shih CYYY', YCHP, XXXI (1946), p. 56. He says: 'It is very strange that $u$ and $y$ were rhymed together, because in the Yüan dramas mo. yiun $(u)$ and $y u ̈-y u ̈ n$ (iu) can be rhymed together'.

22 The final consonant $-m$ in the Hsi-ju Erh-mu-tzu and Matteo Ricci's romanisation is equivalent to $-n g$.

23 In Matteo Ricci's romanisation, [y] is denoted as $i u$ (e. g. 居 kiu, 虛 hiu, 决 kiue, etc.) and $y$ (e. g. 用 $y u m$, 遠 $y u e n$, etc.), João Soeiro's romanisation is ver y 
$-t$, $-p$ with a glottal stop after they had disappeared. Also, as Wang $\mathrm{Li}$ mentions, the Lei-yin 類音 (1712) by P'an Lei 潘末 classifies finals into 師, 衣, 疏 and 於, which represent the nuclei $\imath, i, u$, and $y$ respectively. ${ }^{24}$ Therefore, the phonetic change of $i u$ to $y$ in Old Mandarin might have occurred after the compilation of the CYYY and before the late seventeenth century.

Another problem is the existence of $y$ in the Wu dialects. $\mathrm{Lu} \mathrm{Yu}$ 陸游 (1125-1210), a poet of the Northern Sung dynasty, states in the Lao-hsïeh-an Pi-chi 老學庵筆記: 'Wu people have corrupted the sound of the word 魚 and its rhyme group to k'ai-k'ou.'25 This accords with some of the Wu dialects such as the modern Soochow, Wuhing 吳與, Taiping 太平 dialects, whose sounds of the 魚 group are either $i$ or 1.

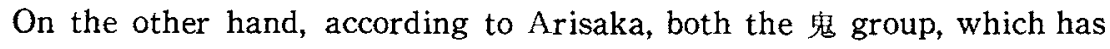
-uei or -ui finals in modern Mandarin, and the 魚 group already included the sound $[y]$ in the Yüan period on the evidence of the To-on version of Sino-Japanese. ${ }^{26}$ This assumption accords with $\mathrm{Ch}^{\prime}$ ien Tahsin's 錢大所 (1728-1804) observation that in the Wu dialects the word 鬼 (Pek. kuei) is pronounced as 擧 (Pek. chü), the word 歸 (Pek. kuei) is pronounced as 居 (Pek. chü), ... the word 椅 (Pek. $i$ ) is read as 于 (Pek. $y \ddot{u}) .{ }^{27}$

The $M K T Y$ in parts reflects some peculiarities of the colloquial sound $y$ in the Wu dialects. In the $M K T Y$, the characters 規, 桂, 葵, 惠, etc. are transcribed as $-i u \varepsilon$, and the characters 輝, 諱, 沙, etc. are transcribed as $-e u \varepsilon$. Almost all the $\mathrm{Wu}$ dialects pronounce these

similar. See Lo Ch'ang-p'ei 'Yeh-su-hui-shih tsai yin-yün-hsüeh shang te keng-hsien', $A S$, I, 3 (1930), pp. 267-338; A. Tōdō, 'Kanwa no seiritsu katei kara mita Seiju Jimokushi', THG, 5 (1930), pp. 99-122; W. Simon, 'The China Illustrata Romanisation of João Soeiro's (Soerio's) Sanctae Legis Compendium and its Attribution to Michael Boym', Studia Serica Bernhard Karlgren Dedicata, pp. 265$70+4$ plates.

${ }^{24}$ Han-yu-shih kao, vol. 1, p. 170. On the book Lei-yin, see Chao Yin-T'ang, Tengyün yüan-liu, pp. 181-7.

25 Lao-hsüeh-an Pi-chi (Ch'in-tai Pi-shu ed. vol. VI, p. 10b).

26 Arisaka, 'Fugin no Tō-on ni han'ei shita Kamakura jidai no on'in jōtai', Kokugo On'inshi no Kenkyü, pp. 199-203.

27 Shih-chia-chai Yang-hsin-lu, vol. V (Ch'ien-yen-t'ang Ch'üan-shu ed.), p. 34a. 
characters as $y$ in the colloquial form and - $2 e$ in the literary form. ${ }^{28}$ The sounds $-i z \varepsilon$ and $-e v \varepsilon$ in the $M K T Y$ perhaps indicate the sound $y$ or its approximation. However, it is difficult to distinguish between $-i u \varepsilon$ and $-e u \varepsilon$. Similariy, in the $M K T Y$, the characters 頻, 璝, 訶, 雄, 熊, etc. are transcribed as -inng, and the characters 弓，松，龍，胃，永 etc. are transcribed as enng. In the Wu dialects, the former group and 兇, 永 of the latter group have the sound -iong, and the latter group (except 希, 永) have the sound -ong. ${ }^{29}$ Therefore, the medial $\cdot i$. and $-e$ - seem in this case to have the function of indicating whether the sounds are deflected or not.

Generally speazing, in 'Phags-pa documents the letters $e$ and $i$ are easily confused with each other, because their shapes $ᄃ(e)$ and $\models$ (i) are very similar. Also it is doubtful whether the person who copied the manuscript of the $M K T Y$ was careful to make the distinction between these two letters. However, the existence of a distinction between them probably indicates that either -eu-or -iu-in the $M K T Y$ can be equivalent to $y$, although the distribution of $-e u$ - and - ir : in the MKTY is not sufficiently consistent because of the similarity of their letter shapes. Therefore, in this paper, I shall simply follow the 'Phags-pa spelling, and adjust the sound in each case in com. parison with modern dialects.

(3) -üeng

The sound hüeng which includes four characters 怳, 况, 貼 and 況 appears in the yang-yün group of the $M K T Y$. These four characters are now pronouncet as ' $k^{\prime}$ uang in Mandarin, and are given as huang in the CYYY. In the Wu dialects they are either huong (Soochow), husng (Hangchow) or hũ (Ningpo). ${ }^{30}$ The sound hüeng in the MKTY is closer to the hunng of Hangchow than to k'uang in Mandarin because of its front vowel.

(4) $-u \varepsilon$

With the exception of the entering-tone, the characters belonging

28 See Chao Yuen-ren, op. cit., Table II, 7.

29 See ibid., Table II. 5, 12 .

30 The characters 怳, 淔, 貺, and 海 have undergone a phonetic change $h>k$. 
to the $-u \varepsilon$ group in the $M K T Y$ are pronounced $-e i$ or $-u e i$ in Mandarin, while they are $-e,-E,-u e,-u E$ in the literary form and $-y$ in the colloquial form of the Wu dialects. ${ }^{31}$ But the characters of the Ancient Chinese entering-tone group are not always similar to the Wu dialects; for example 國 $(k u \mathcal{E})$ is $k o, k j, k u \partial$ and 域 $(\cdot u \mathcal{E})$ is $i, y o, y \partial$, etc. ${ }^{32}$ In general, the distribution of the entering-tone in the $M K T Y$ is very difficult to grasp, and this problem will be discussed in the next section.

(5) -ŭin

The characters 笽, 熅, 雲, 韻, etc. are pronounced as [yn] in

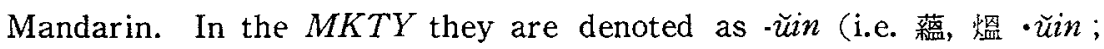
雲, 韻 $y \breve{u}(n)$, and are distinguished from the 君, 春, 允, 薰 group,

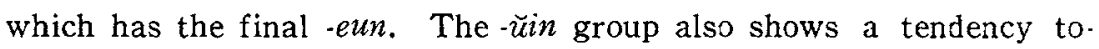
wards the $\mathrm{Wu}$ dialects, such as $y \imath n$ (Hangchow) and $y \imath(n g)$ (Kiuchow).33

(6) nuclei and medials

Basing upon all the finals in the $M K T Y$, the nuclei and medials and their connections with endings can be shown as the following table:

Other examples are given in Karlgren, Études sur la phonologie chinoise, p. 372. 31 See Chao Yuen-ren, op. cit., Table II. 2,7. But some of the characters of this group are pronounced as $y$ in the colloquial form, except in the Hangchow and Kiuchow dialects.

32 See ibid., Table III, 4.

33 She idid., Table II. 13. 


\begin{tabular}{|c|c|c|c|c|c|c|c|c|}
\hline \multirow{2}{*}{\multicolumn{2}{|c|}{ medials $\left.\right|_{\text {nuclei }} ^{\text {endings }}$}} & \multicolumn{4}{|c|}{ yin-lei } & \multicolumn{3}{|c|}{ yang-lei } \\
\hline & & - & $-j$ & $-w$ & $-\varepsilon$ & $-n g$ & $-n$ & $-m$ \\
\hline- & \multirow{4}{*}{$a$} & (a) & $a j$ & $a w$ & - & $a n g$ & $a n$ & $a m$ \\
\hline.$\check{\imath}$. & & $\breve{\imath} a$ & $\check{i} a j$ & zaw & 一 & žang & žan & Iam \\
\hline$-\breve{u}$. & & $\breve{u} a$ & $\breve{u} a j$ & $\breve{u} a w$ & - & ŭang & ŭan & - \\
\hline$-\underline{h}$. & & - & - & - & - & hang & - & - \\
\hline - & \multirow{2}{*}{$o(0)$} & - & 一 & $o w$ & 一 & ong & $o_{N}$ & - \\
\hline$e$ & & - & 一 & - & - & - & $e Q_{N}$ & - \\
\hline 一 & \multirow{2}{*}{$o$} & $o$ & - & - & - & 一 & - & - \\
\hline$\breve{u}$ & & $\breve{u} o$ & - & - & 一 & 一 & - & - \\
\hline- & \multirow{4}{*}{$u$} & $u$ & - & $u w$ & $u \varepsilon$ & ung & $u n$ & - \\
\hline$-\check{z}$. & & 一 & - & - & เัuर & žung & - & - \\
\hline$-e$ & & $e u$ & - & - & $e u \varepsilon$ & eung & eun & - \\
\hline$-\breve{u}-$ & & - & - & - & 一 & $\breve{u} u n g$ & - & 一 \\
\hline- & \multirow{3}{*}{$\varepsilon$} & $(\varepsilon)$ & - & $\varepsilon w$ & - & - & $\varepsilon n$ & $\varepsilon m$ \\
\hline$-\vec{z}$. & & - & - & - & - & - & $\check{\imath} \varepsilon n$ & ฉ̌ฒm \\
\hline$-\breve{u}$. & & $\check{u} \varepsilon$ & - & - & - & 一 & - & 一 \\
\hline - & \multirow{2}{*}{$e$} & $e$ & - & $e w$ & - & - & $e n$ & $\mathrm{em}$ \\
\hline$-\breve{u}-$ & & ŭe & - & ǔew & 一 & ŭeng & üen & 一 \\
\hline - & \multirow{5}{*}{$i$} & $i$ & $i j$ & $i w$ & - & ing & in & $i m$ \\
\hline$-\breve{i}$ & & - & - & - & 一 & žing & - & iim \\
\hline$e$ & & $e i$ & - & $e i w$ & - & eřng & ein & - \\
\hline$-\breve{u}-$ & & $\breve{u} i$ & - & - & - & 一 & ŭin & - \\
\hline$-\underline{h}$. & & $\underline{h} i$ & $\underline{h} i j$ & $\underline{h i w}$ & - & hing & $\underline{h i n}$ & $\underline{h i m}$ \\
\hline
\end{tabular}

From this table, the following seven nuclei can be abstracted; $a$, $o, \supset, u, \varepsilon, e$, and $i$. However, phonetically speaking, another three nuclei may also be supposed to exist in the $M K T Y ;[\mathrm{D}, \mathrm{r}, \propto]$. These three nuclei can be phonologically interpreted as equivalent to -ha-, $-\underline{h i},-\underline{h} i$ - respectively.

As regards the medials, the $M K T Y$ has four medials; $-\bar{\imath}-,-e-,-\breve{u}$ - 
and $-\underline{h}$-, while the $C Y Y Y$ has only two; $-i-$ (or $-j \cdot$ ) and $-w-$. Also the $M K T Y$ has four endings in the yin-lei group; null (ends with nucleus), $-j,-w$ and $-\varepsilon$, while the $C Y Y Y$ has three; null, $-j$ and $-w$. Therefore, in the $M K T Y$, the phonomes $e$ and $\varepsilon$ are used as nucleus and medial/ ending. As to the final consonants in the yang-lei group, both the $M K T Y$ and $C Y Y Y$ have $-n g,-n$ and $-m$ as in Ancient Chinese.

Seven nuclei in the MKTY can be diagrammed in comparison with Ancient Chinese and the $C Y Y Y$ as follows:

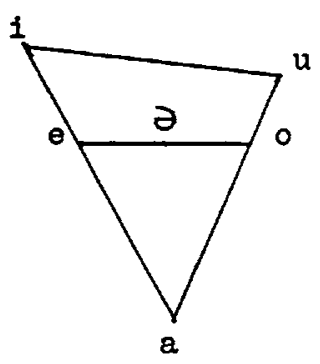

CYYY

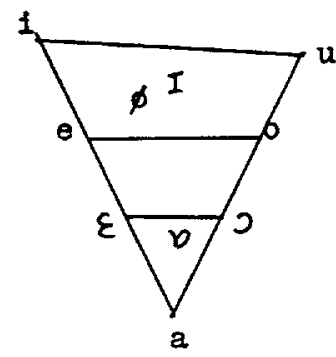

MKTY

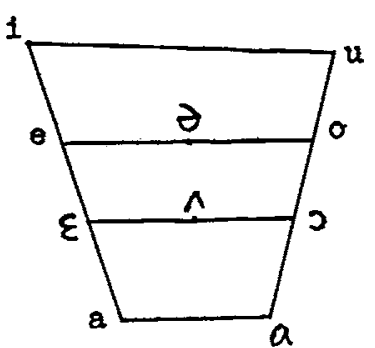

AC

\section{§ 4 Distribution of the Entering-tone}

As well known, the entering-tone in Ancient Chinese disappeared in the Mandarin-speaking area since about the eleventh century. In the HCCS, we see the first indications of the disappearance of the final consonants of the entering-tone, while by the time the CYYY was composed, there was no trace of this tone. Also in the $M K T Y$, it may be noted that the entering-tone had already disappeared as a phonetic value but still existed as a tone. For example, the sound $k i$ does not signify one of the finals $-k,-t,-p$, but is distributed to four groups depending upon its tone; $\boldsymbol{p}^{\prime}$ ing-sheng (level-tone), shang-sheng (fallingrising-tone), ch'ü-sheng (falling-tone), and $j u$-sheng (entering-tone). This shows that the entering-tone still existed as one of the four tones in Ancient Chinese, but the final consonants $-k,-t,-p$ had already disappeared. In this section, I intend to clarify the distribution of the entering-tone in the $M K T Y$, with particular reference to the exhaustive studies of this subject by Keiya. ${ }^{34}$

34 See 'Nisshō inbi shōshitsu no katei ni tsuite no ichi kasetsu-MTKY karano apu- 
The earliest source material which shows an indication of the disappearance of the final consonants of the entering-tone is the HCCS. In this simple rhyme table, the characters 岳, 霍, 六, 玉, 日, 骨, 德 and 北 are not allocated to the yong-lei group but to the yin-lei group which ends with either a nucleus or one of the medials. On the other hand, the characters + and are allocated to the $m$ series in the yang-lei group, just as in Ancient Chinese. This means that the final consonants $-k,-t$ and $-p$ no longer have the same nature as in Ancient Chinese. Chou Tsumo interprets this phenomenon as indicating that the entering-tone had changed to a comparatively short and quick sound, ${ }^{35}$ but he does not establish the actual sounds of these characters which had formerly ended with either $-k$ or $-t$. On the other hand, Ogawa proposes that in the HCCS the dental final consonant $t$ and velar final consonant - $k$ are confused with each other, having already been assimilated to the glottal stop .. ([?]), and only the bilabial consonant $-p$ has still retained its original nature. Ogawa points out that the most of the $k u$ - $t^{\prime} i$-shih 古體詩 ('old style poems') by Su Tung-p'o 蘇東坡 (1036-1101) rhyme between - $t$ and $-k$ although the other poets of his day still archaised to the traditional rhyming. This would reflect the spoken language in North China at that time, supposing Su Tung-p'o to have made free use of colloquial sounds. ${ }^{36}$

However, in the $t z$ ' $u$ poetry (lyric poems) of the Sung period, confused rhyming between $-k,-t$ and $\cdot p$ final consonants can be seen very frequently. According to Sakai's study of rhyme in the $t z^{\prime} u$ poetry, the

\footnotetext{
rōchi,' $N D B K R, X X X V I I(1965)$, pp. 1-37. Keiya also contributes to this problem in the following articles: 'Pei-yin ju-sheng yen-pien k'ao fusetsu', ibid, XL (1966), pp. 45-110; 'Nisshē inbi no shōshitsu ni kansuru ichi mondai', Kotoba, XXXIV (1966), pp. 15-37; 'Onsetsu kōsei to on'in henka - Kohoku hōgen ni okeru nisshō inbi shōshitsu no katei', NDBKR, XLIII (1967), pp. 17-49.

35 Chou Tsu-mo, 'Sung-tai Pien-Lo yü-yen k'ao', pp. 237-8.

36 Ogawa, 'Su Tung.p'o koshi yc̄in kō,' Kyōto Daigaku Bungakubu Gojisshūnen Kinen Ronsh $\bar{u}$, pp. 843-70. Also the rhyming pattern in the chu-kung-tiao poems [Ch'en Shou-yi translates this term as 'a song of narrative nature in which musical airs of various keys were used' in his book, Chinese Literature (New York: The Ronald Press Company, 1961), p. 441] is helpful for understanding the distribution of the entering-tone. Cf. Liao Hsün-ying, 'Chu-kung-tiao te yung-yün', $Z Y$, 128 (1964), pp. 19-27.
} 
confusions between three final consonants are as follows: ${ }^{37}$

Table 14

\begin{tabular}{cccccc}
\hline & $-k$ & $-t$ & $-p$ & $-k,-t,-p$ & total \\
\hline$-k$ & 70 & 25 & 8 & 20 & 123 \\
$(\%)$ & $(57)$ & $(20)$ & $(7)$ & $(16)$ & $(100)$ \\
\hline$-t$ & 25 & 20 & 48 & 20 & 113 \\
$(\%)$ & $(22)$ & $(18)$ & $(42)$ & $(18)$ & $(100)$ \\
\hline$-p$ & 8 & 48 & 5 & 20 & 81 \\
$(\%)$ & $(10)$ & $(59)$ & $(6)$ & $(25)$ & $(100)$ \\
\hline
\end{tabular}

From the proportion of confusions between these three final consonants, Sakai proposes that the final consonants of the entering-tone in the Sung period can be divided into two groups; the $-k$ group, and the $t$ group which assimilated the $-p$ group. This contrasts with the hypothesis derived from the HCCS, which suggests that confusion between $-k$ and $-t$ came first and resulted in $\cdot \cdot$. The two hypotheses are illustrated in the fol. lowing scheme.

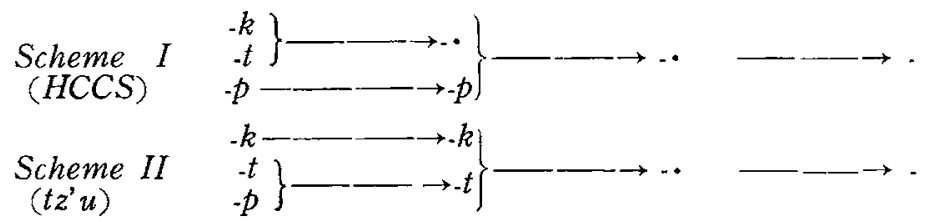

It is still difficult to conclude which of these is more adequate to explain the disappearance of the final consonants of the entering-tone during the transitional period of Old Mandarin. However, it may be suggested that differences between the two pypotheses reflect differences in the Sung period dialects. ${ }^{38}$ To clarify this problem, it will be useful to examine the distribution of the entering-tone in the $M K T Y$ as shown by Keiya : ${ }^{39}$

37 Sakai, 'Sõshi cinji ni mirareru on'injō no ichini no tokushoku', TYGH, XXXVIII, 2(1955), pp. 85-113, esp. see p. 100 .

38 P. Serruys, 'Chinese dialectology based on written documents', MS, XXI(1962), p. 335 describes the manner of merging between $-k,-t$ and $-p$ only as in Scheme II without considering the case of the HCCS, but, as Table 14 shows, the confusion between.$k$ and $-t$ is not consequent but shows only a statistical majority.

39 'Nisshō inbi shōshitsu no katei ni tsuite no ichi kōsatsu', pp. 166-8. The ori- 
Table 15

(i)

\begin{tabular}{c|c|c|c}
\hline$-p$ & $-t$ & $k-$ & $M K T Y$ \\
\hline \hline & $a u k$ & \\
& $a k$ & $-a w$ \\
& $\check{\imath} a k$ & \\
\hline & $a u k$ & $-\check{u} a w$ \\
& $u a k$ & \\
\hline & $a u k$ & $-\check{\imath} a w$ \\
\hline & $\check{\imath} a k$ & $-\varepsilon w$ \\
\hline & $\check{\imath} a k$ & $-e w$ \\
\hline & $\breve{\imath} u a k$ & $-\breve{u} e w$ \\
\hline
\end{tabular}

(ii)

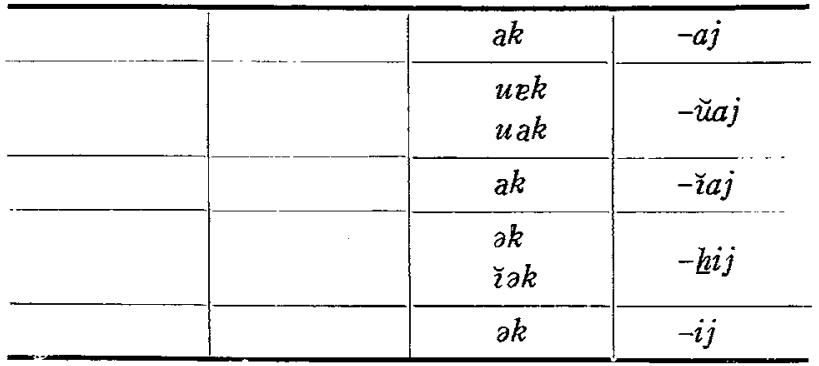

(iii)

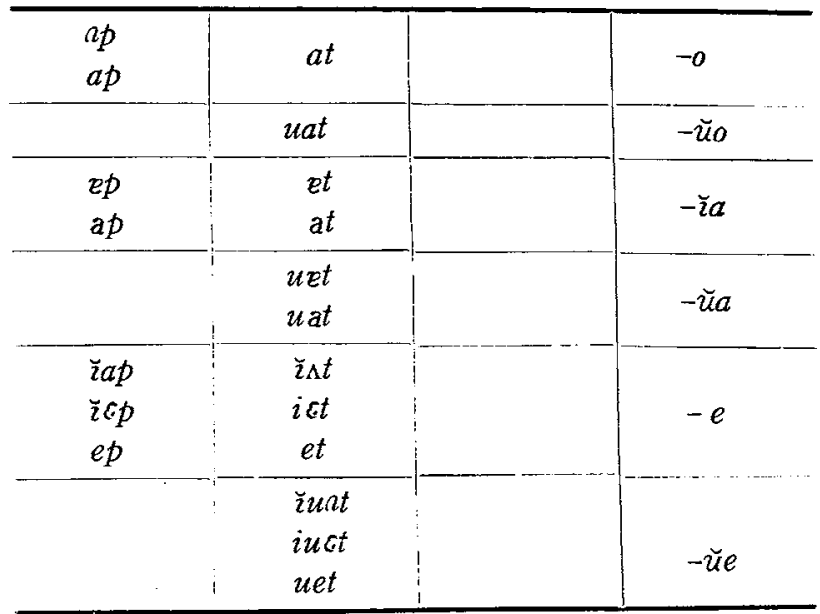




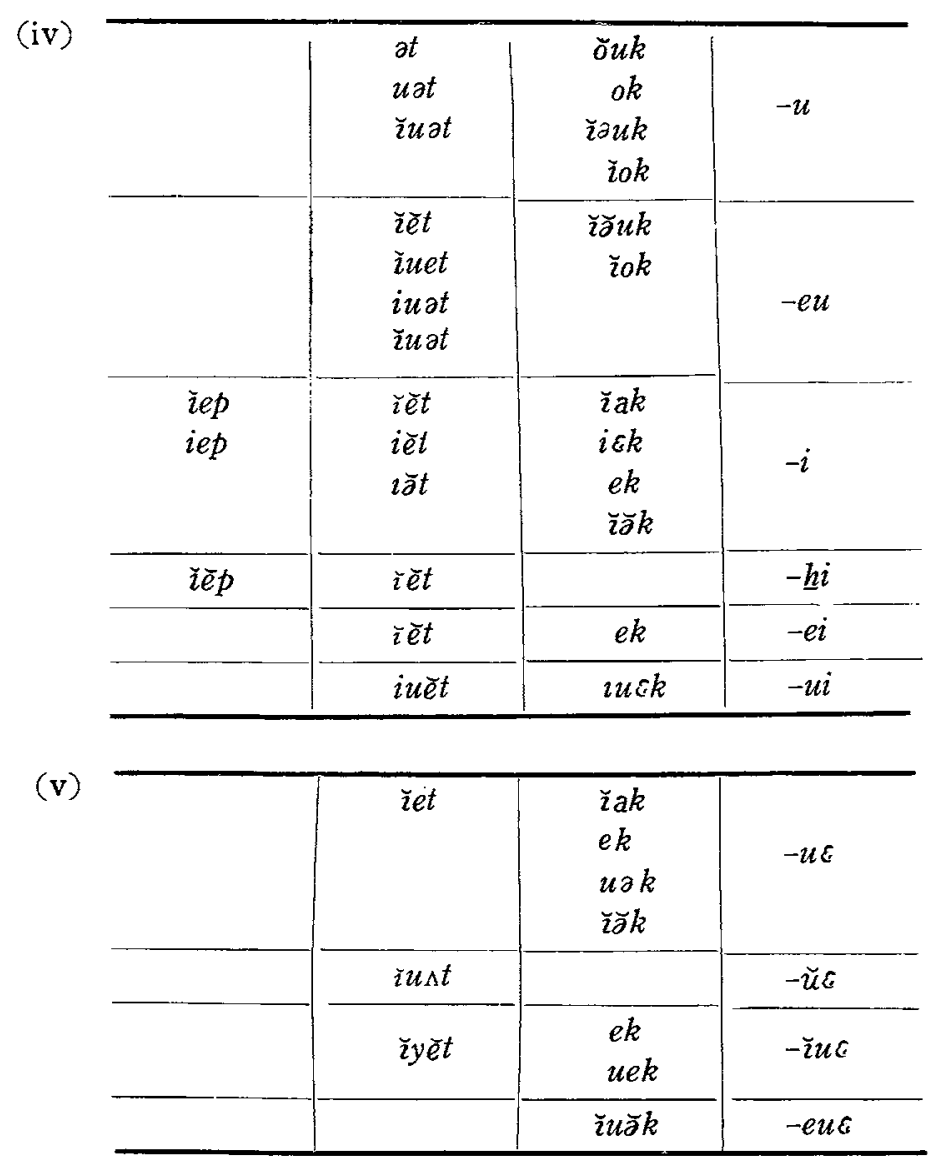

Keiya also summarises the above tables in the following table:

Table 16

\begin{tabular}{llc}
\hline group & \multicolumn{1}{c}{ conditions } & MKTY \\
\hline $\begin{array}{l}k \mathrm{I} \\
(\mathrm{ImN} k)\end{array}$ & $\begin{array}{l}\text { high vowel }+k \\
i(\mathrm{med})+\text { mid. vowel }+k\end{array}$ & $\begin{array}{c}\mathrm{I}^{\prime} \mathrm{m}^{\prime} \\
\left.\text { (or } \mathrm{I}^{\prime} \mathrm{m}^{\prime} \text { ) }\right)\end{array}$ \\
\hline $\begin{array}{l}k \mathrm{II} \\
(\mathrm{ImN} k)\end{array}$ & $\begin{array}{l}\text { mid. vowel }+k \\
\text { (no med. } i)\end{array}$ & $j$ \\
\hline$k \mathrm{III}$ & $\begin{array}{l}\text { low vowel }+k \\
\text { (regardless med. } i)\end{array}$ & $w$ \\
\hline
\end{tabular}




\begin{tabular}{llc}
\hline $\begin{array}{l}t, p 1 \\
(\operatorname{ImN} t, \operatorname{ImN} p)\end{array}$ & high syllable 40 & $\begin{array}{l}\mathrm{I}^{\prime} \mathrm{m}^{\prime} \\
\left.\text { (or } \mathrm{I}^{\prime} \mathrm{m}^{\prime} ~ ?\right)\end{array}$ \\
\hline $\begin{array}{l}t 2, p 2 \\
(\operatorname{ImN} t, \operatorname{ImN} p)\end{array}$ & non-high syllable & $\begin{array}{c}\mathrm{I}^{\prime} \mathrm{m}^{\prime} \mathrm{N}^{\prime} \\
\left(\text { or } \mathrm{I}^{\prime} \mathrm{m}^{\prime} \mathrm{N}^{\prime} ?\right)\end{array}$ \\
\hline
\end{tabular}

$I=$ initial consonant ; $\mathrm{m} /$ med. = medial ;

$\mathrm{N}=$ nucleus $;$ mid. $=$ middle.

Keiya states:

In the above table, it seems to be a lack of consistency in that the final $\cdot k$ is divided into three groups, and the finals $-t$ and $-p$ into two groups. However, phonetically speaking, the region of change of $-k$ is wider than that of $-t$ and $-p$ because the point of articulation of $-k$ is further back than $-t$ and $-p$ in the mouth. For example, in the following cases, the initial consonant and nucleus in the same, but the final consonant is slightly different $p a k$, pat and $p a p$, it is even possible that these final consonants might disappear, to result in $p a .^{\circ}$ But in actual fact, the $a$ nucleus, in $p a k$ leads to a wider opening of the mouth than with other instances. 41

To interpret this peculiar function of the final $-k$, Keiya proposes the existence of the glides $-w$ and $-j$ as follows:

$$
\begin{aligned}
& -a k^{w} \longrightarrow-a g^{w} \longrightarrow-e^{w} g^{w} \quad(\text { or }-a w g w) \longrightarrow \longrightarrow-a w \\
& \left.-e k^{\prime} \longrightarrow-k g^{\prime} \longrightarrow-a^{i} g^{j} \quad \text { (or }-a j g j\right) \longrightarrow-a^{j}
\end{aligned}
$$

In fact, this formula follows Rai's hypothesis, which assumes a phonological opposition between $-k$ and $-q(=[\overparen{\mathrm{kW}}])$ in Archaic Chinese. ${ }^{42}$ Also Arisaka proposes a glide as follows :43

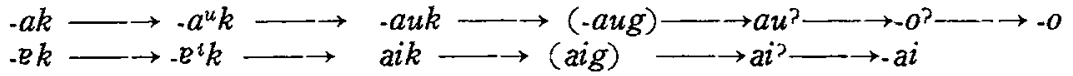

ginal tables presented by Keiya give Chinese characters which signify the traditional rhyme groups, but the denotation of these tables is the work of the present author.

40 According to Keiya, high vowel (syllable), middle vowel (syllable) and low vowel (syllable) can be shown in the right diagram (see Keiya, p. 184):

41 Keiya, op. cit., p. 169.

42 Rai, 'Jōko Chūgokugo no kõtō inbi ni tsuite', OJDJK, III (1953), pp. 51-64.

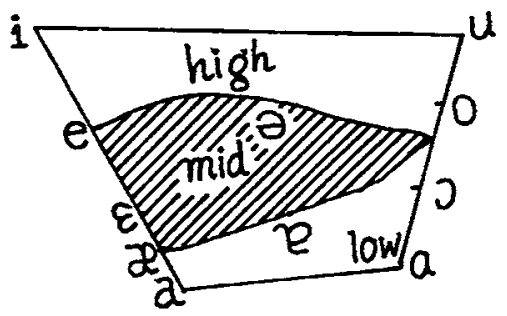

43 Arisaka, 'Nisshō inbi shōshitsu no katei', Kokugo On'inshi no Kenkȳu, pp. 
In general, the consonant $k$ has a peculiar nature. The syllables which had the final $-k$ and the initial $k$ - series accompanied by middle or low nuclei had easily combined with the medial $-\bar{\imath}$ - intending the further palatalisation (e. g. kauk/pauk $\rightarrow$ kĭaw/paw). ${ }^{44}$

In the $C Y Y Y$ the characters which formerly had final consonants of the entering-tone in Ancient Chinese are shared amongst the yang-p'ingsheng (rising-tone), shang-sheng (falling-rising-tone), or ch'ü-sheng (falling-tone) groups, depending on the nature of their initials. ${ }^{45}$ Lu Chih-wei proposes that even in the $C Y Y Y$ the entering-tone has been partly re-

601-7. This scheme is based on the suggestions of Arisaka as summarized by Keiya.

44 Ozaki points out that in the $M K T Y$ the velar initials of deflective syllables had already been palatalised, as is shown by the following passage of Chu Tsung. wen's preface to the $M K T Y$ : “古今䫓會於每字之首必以四聲釋之, 由是始知見經堅爲 ఐ]', which Ozaki interprets to mean 'In the Ku-chin Yïn-hui, all the sound groups are arranged under one of the $t z u-m u$ (initials). From this arrangement, I realized for the first time that the initial consonant of the characters 見, 經 and 堅 is $g$. [In fact, these characters are not pronounced as $g$ although they are denoted as $g$ in the 'Phags-pa script. But now $I$ realized that the original sound of these characters was $g$ by use of the Ku-chin Yün-hui.)(Ozaki, 'Daiei Hakubutsu. kan-bon MKTY sakki', pp. 167-174). Thus Ozaki proposes that the velar initials of deflective syllables had already been palatalised by this time. This hypothesis is similar to Chao Yin-t'ang's assumption (CYYY Yen-chiu, pp. 88-93). Ozaki also criticizes Tödo's theory that palatalisation occurred between the seventeenth and nineteenth centuries, in his ' $K i$ - to $t s i$ - no kondo wa 18 seiki ni hajimaru', $C G, 94$ (1960), pp. 1-3, 12; 'Development of Mandarin from 14c. to 19c.' $A A$, VI (1964), pp. 38-9. However, Todō's hypothesis is more acceptable, since in many rhyme dictionaries such as the Yün-lüeh I-t'ung, Wu-fang Yüan-yin and Hsi-ju Erh-mu$t z u$, written during the fourteenth and seventeenth centuries, velar initials have still not undergone palatalisation. Also Chu Tsung-wen's words quoted above might be interpreted as follows : '...From this arrangement $I$ realized for the first time that the initial consonant of the characters 見, 經 and 堅 is $g$. [In fact, these characters are pronounced as $k$ although they are denoted as $g$ in the 'Phags-pa script. But I now realized that in the 'Phags-pa transcription of Chinese there is an alternation between voiced and voiceless initials like $k$ and $g.]^{\prime}$. According to my interpretation of Chu Tsung-wen's preface, it is impossible to infer the exiitence of palatals in the $M K T Y$.

45 According to H. Hirayama, 'Chūko nisshō to Pekingo seichō no taiō tsūsoku', NCGH, XII (1960), pp. 139-156, it must be noted that the some of modern Pekinese sounds have colloquial and literary versions. The colloquial element may be taken as basic Pekinese, but the literary element is supposed to consist of many other dialects in the form of loan-sounds (cf. Table 3 in his article). 
tained, as [?], $[q]$ or $[6]$, and he explains: ' $\ldots$ the disappearance of [G] which is a fricative final consonant possibly originated from the changing of $t z^{\prime} u$-cho (nasals and semi-vowels) to the falling-tone, thereafter gradually leading to complete extinction.' ${ }^{46}$

Thus the difficulty in dealing with the disappearance of the entering. tone in the CYYY lies in its relationship with other tones. ${ }^{47}$ Although Lu Chih-wei proposes the existence of a glottal stop replacing the former $-k, \cdot t$ and $-p$, the fact that the entering-tone syllables had already been distributed amongst other three tones means that the trace of glottal stop at the end of syllables must have been very weak and already tending to disappear.

On the other hand, in the $M K T Y$ the four tones of Ancient Chinese have all been preserved, although the final consonants of the enteringtone have already been dropped. It is therefore considered that in the $M K T Y$ those characters which formerly had the final consonants of the entering-tone (except $-k$ accompanied by middle / low vowel) have a clear glottal stop [?] at the end of each syllable.

Comparing this feature in the $M K T Y$ with that in the $C Y Y Y$, we can phonologically interpret as follows:

Table 17

\begin{tabular}{clll}
\hline AC & CYYY & MKTY & Wu dialects $^{48}$ \\
\hline high vowel $+k$ & - &.$\cdot$ \\
middle vowel $+k$ & $-j$ & $-j$ & \\
low vowel $+k$ & $-w$ & $-w$ & \\
\hline$-t$ & - &.. & \\
\hline$-p$ & - &.$\cdot$ & \\
\hline
\end{tabular}

46 'Shih $C Y Y Y$ ', pp. 63-6. However, according to his 'Kuo-yü ju-sheng yen-pien hsiao-chu', YCHP, XXXIV (1948), pp. 21-8, [u] is corrected to [ $j]$. This theory was criticized by Chao Hsia-ch'iu and Tseng $\mathrm{Ch}^{\prime}$ 'ing-jui in their 'CYYY yin-hsi te chi-ch'u ho ju-p'ai san-sheng te hsing-chih', $Z Y, 117(1962)$, pp. 312-24.

47 See Keiya, 'Pei-yin-ju-sheng yen-pien $k$ 'ao fusetsu', which critically treats Po Ti-chou's proposal and adds many supplementary materials based on exhaustive investigation of the CYYY, Chung-chou Yin-yün, Tz'u-lin yün-shih and Yin-yiun ch'ih-cho chien. 
The MKTY reveals that the distribution of the ending .. is similar to that of the $\mathrm{Wu}$ dialects, while the existence of the endings $-j$ and $-w$ is more similar to the CYYY. It is very unlikely that the $M K T Y$ 's $-j$ and $-w$ have changed to .- because phonetic change such as $-j>\cdot \cdot$ is incongruous. Thus we may conclude that in the respect of the disappearance of the final consonants of the entering-tone the $M K T Y$ has two aspects of both the Wu dialects and Mandarin, although the Wu element seems to be more dominant in it.

\section{\& 5. Conclusion}

The sound system employed in the MKTY has many elements of the Wu dialects, although it has a partly Mandarin element. As far as the initial consonant system is concerned, it seems very strange that the $M K T Y$ preserves voiced initials and retroflex initials which are the peculiarities of the $\mathrm{Wu}$ and Mandarin dialects respectively. However, it must be noted that the $M K T Y$ was compiled in the Yü an dynasty, just after voiced initials had disappeared in the Mandarin-speaking area. It might have been easy for the Pien-ching people to preserve the voiced initials which were retained in the $\mathrm{Wu}$ dialects when they moved to Lin-an, because this transfer of the capital in the Northern Sung dynasty (1138) took place when Mandarin was still in the transitional period. As Hattori explains, ${ }^{49}$ when the Pien-ching dialect was transplanted to Linan, voiced initials might still have been preserved even in Mandarin. On the other hand, the retroflex initials in the $M K T Y$ are also rendered as affricated alveolo-palatals, which were vestiges of Ancient Chinese in the Wu dialects.

In the final system, the number and nature of nuclei are obviously much more complicated and archaised than in the CYYY. Also as to the other peculiarities of the final system, in particular the peculiar $n$, the $M K T Y$ shows more similar elements to the Wu dialects than to

48 According to the Hsien-tai Wu-yü te Yen-chiu, the phonetic change of the entering-tone in the $\mathrm{Wu}$ dialects is very simple. The nuclei have scarcely been influenced by the change of the final consonant to the glottal stop.

49 Hattori, op. cit., p. 55. 
Mandarin. On the Hangchow dialect, Chao Yuen-ren explains :

Harngjou (Hangchow), being the capital of the Southern Sonq (Sung) Dynasty, retain a good deal of Mandarin influence. Whereas all the other Wu-dialects have a literary and a colloquial pronunciation for a large number of words, Harngjou uses only the literary form whether in speech or in writing. There is therefore no striking difference in pronunciation between reading a literary passage in the Harngjou dialect and reading in the Shawhing (Shaohing) dialect, while the colloquial speech of Harngjou sounds very different from the surrounding dialects. ${ }^{50}$

Hattori's assumption and Chao's observation thus accord with each other. Although in general I agree with Hattori's hypothesis that the sound system employed in the MKTY may perhaps be the Pien-ching dialect as transplanted to Lin-an, I also think that Chu Tsung-wen might have referred to the sound system of the Kiuchow dialect in minor points. Therefore, as a general conclusion, it can be said that the sound system employed in the $M K T Y$ is one of the prototypes of literary form of the Wu dialects.

\section{§6. The Text of the Meng-ku Tzu-yün}

This section is intended to show all the syllables represented in the $M K T Y$. The table below consists of (1) 'Phags-pa spellings, (2) Chinese sounds, (3) distribution of tones and representative characters in each tone group, and (4) page number in the texts of the Kansai University edition (abbr. $M K J I$ ) and the new Chinese manuscript in the PSPT (abbr. PSPT' (in) parentheses).

$\mathbf{p}=p^{\prime}$ ing-sheng (level-tone); $\mathrm{s}=$ shang-sheng (falling-rising-tone); $\mathrm{c}=$ chü-sheng (falling-tone) $; j=j u$-sheng (entering-tone) $;, t, p$ after the $j u$-sheng column denote the final consonants $-k, \cdot t, \cdot p$ of the Ancient entering.tone respectively.

50 Chao Yuen-ren, op. cit., 'Introduction in English', p. xiv. 
1. tung-yün 東韻

MENG-KU TZU-YÜN

Volume I

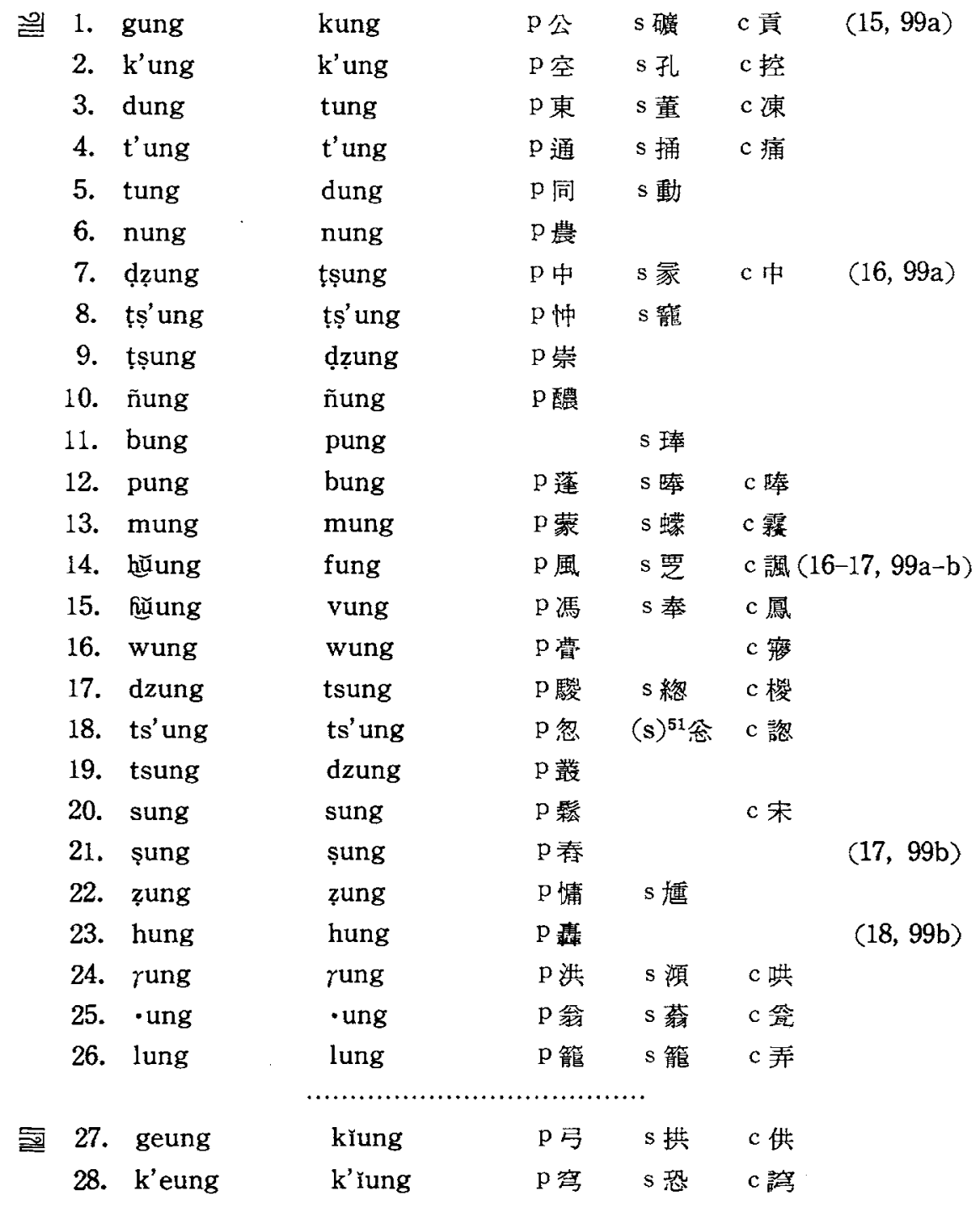

51 Both the $M K J I$ and $P S P T$ editions lack the character 上 (shang-sheng). 


\begin{tabular}{|c|c|c|c|c|c|}
\hline 29. keung & gǐung & $\mathrm{p}$ 窮 & & c 共 & \\
\hline 30. ḍzeung & ț̣̦iung & $\mathrm{p}_{\text {蟲 }}$ & $\mathrm{s}$ 重 & $\mathrm{c}$ 仲 & \\
\hline 31. dzeung & tsǐung & $\mathrm{p}$ 縱 & & $\mathrm{c}$ 從 & $(19,100 a)$ \\
\hline 32. ts'eung & ts'ǐung & $\mathrm{p}$ 樅 & & & \\
\hline 33. tseung & dzĭung & $\mathrm{p}$ 從 & & c 從 & \\
\hline 34. seung & sĭung & $\mathrm{p}$ 容 & $\mathrm{s}$ 悚 & & \\
\hline 35. zeung 52 & ziuung & $\mathrm{p}$ 松 & & ' $\mathrm{c}$ 頌 & \\
\hline 36. heung & hrung & $\mathrm{p}$ 胃 & & c 复 & \\
\hline 37. eung & • sung & $\mathrm{p}$ 䔨 & $\mathrm{s}$ 擁 & c 䔨 & \\
\hline 38. yeung & yǐung & $\mathrm{p}$ 顆 & $\mathrm{s}$ 永 & $\mathrm{c}$ 詠 & \\
\hline 39. - jeung & xǐung & $\mathrm{p}$ 蓀 & & & \\
\hline 40. jeung & jǐung & $\mathrm{p}$ 融 & $\mathrm{s}$ 角 & $\mathrm{c}$ 用 & $(20,100 a)$ \\
\hline 41. leung & lǐung & $\mathrm{p}$ 隆 & $\mathrm{s}$ 隴 & & \\
\hline 42. reung & rĭung & $\mathrm{p}$ 戎 & $\mathrm{s}$ 几 & & \\
\hline
\end{tabular}

2. keng-yün 庚韻

\begin{tabular}{|c|c|c|c|c|c|c|}
\hline 43. & ging & king & $\mathrm{p}$ 警 & $\mathrm{s}$ 整 & $\mathrm{c}$ 敬 & \\
\hline 44. & $k^{\prime}$ ing & $\mathrm{k}^{\prime}$ ing & $\mathrm{p}$ 卿 & & c 慶 & \\
\hline 45. & king & ging & $\mathrm{p}$ 擎 & & c 競 & \\
\hline 46. & ning & ning & $\mathrm{p}$ 迎 & & c 迎 & \\
\hline 47. & ding & ting & $\mathrm{p} 丁$ & $\mathrm{~s}$ 朾 & $\mathrm{c}$ 石 & \\
\hline 48. & t'ing & t'ing & $\mathrm{p}$ 汀 & s 理 & c 聼 & $(21,100 b)$ \\
\hline 49. & ting & ding & $\mathrm{p}$ 庭 & $\mathrm{s}$ 挺 & $\mathrm{c}$ 定 & \\
\hline 50. & ning & ning & $\mathrm{p}$ 等 & $\mathrm{s}$ 顎 & c 憲 & \\
\hline 51. & ḍz̧ing & ț̣sing & $\mathrm{p}$ 貞 & $s$ 整 & c 政 & \\
\hline 52. & țș'ing & țșing & $\mathrm{p}$ 檉 & $\mathrm{s}$ 涅 & c 邊 & \\
\hline 53. & ț̣̦ing & dzing & $\mathrm{p}$ 呈 & & $\mathrm{c}$ 鄭 & \\
\hline 54. & bing & ping & $\mathrm{p}$ 兵 & $s$ 丙 & $\mathrm{c}$ 柄 & $(21-22,100 \mathrm{~b})$ \\
\hline 55. & p'ing & $p^{\prime}$ ing & $\mathrm{p}$ 俜 & & $\mathrm{c}$ 聘 & \\
\hline 56. & ping & bing & $\mathrm{p}$ 平 & $\mathrm{s}$ 竨 & $\mathrm{c}$ 病 & \\
\hline 57. & ming & ming & $\mathrm{p}$ 冥見 & $\mathrm{s}$ IIII & $c$ 命 & \\
\hline 58. & dzing & $\mathrm{t}$ sing & $\mathrm{p}$ 蜻 & s 井 & c 臯 & \\
\hline 59. & ts'ing & ts'ing & $\mathrm{P}$ 鯖 & $\mathrm{s}$ 請 & c 倩 & \\
\hline 60. & tsing & dzing & $\mathrm{p}$ 情 & $\mathrm{s}$ 静 & c 凈 & \\
\hline
\end{tabular}

52 For $\exists \operatorname{read} \exists$. 


\begin{tabular}{|c|c|c|c|c|c|}
\hline 61. sing & sing & $\mathrm{p}$ 星 & $\mathrm{s}$ 醒 & c 醒 & $(23,101 \mathrm{a})$ \\
\hline 62. zing & zing & $\mathrm{p}$ 鶬 & & & \\
\hline 63. șing & șing & $\mathrm{p}$ 聲 & & $c$ 聖 & \\
\hline 64. zing & zing & p成 & & c 盛 & \\
\hline 65. ring & ring & $\mathrm{p}$ 恒 & & & \\
\hline 66. - ing & - ing & $\mathrm{p}$ 霆 & $\mathrm{s}$ 影 & $\mathrm{c}$ 映 & \\
\hline 67. ·jing & xing & $\mathrm{p}$ 販 & $\mathrm{s}$ 㿉 & $\mathrm{c}$ 鎣 & \\
\hline 68. jing & jing & $\mathrm{p}$ 媇 & $\mathrm{s}^{53}$ 趴 & $\mathrm{c}$ 䩿 & \\
\hline 69. ling & ling & $\mathrm{p}$ 令 & $\mathrm{s}$ 領 & $c$ 令 & $(24,101 a)$ \\
\hline 70. ring & ring & $\mathrm{p}$ 仍 & & & \\
\hline
\end{tabular}

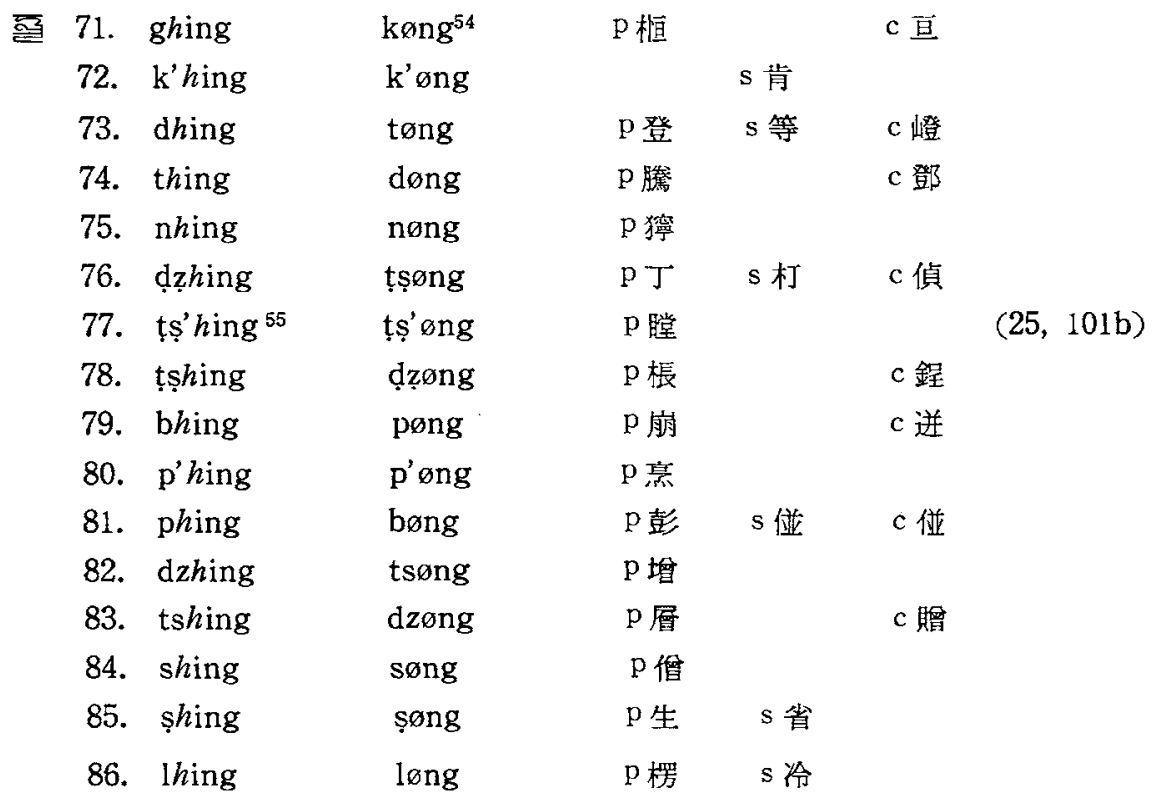

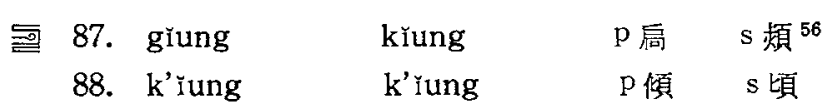

53 For 去 (after 䠉) read 上.

54 See Chapter III, $3 . \quad 55$ For $\square$ read $\bar{~}$.

56 The $P C H$ gives the Nos. 27-42 group as -eung. See Dragunov, op. cit., 熊 


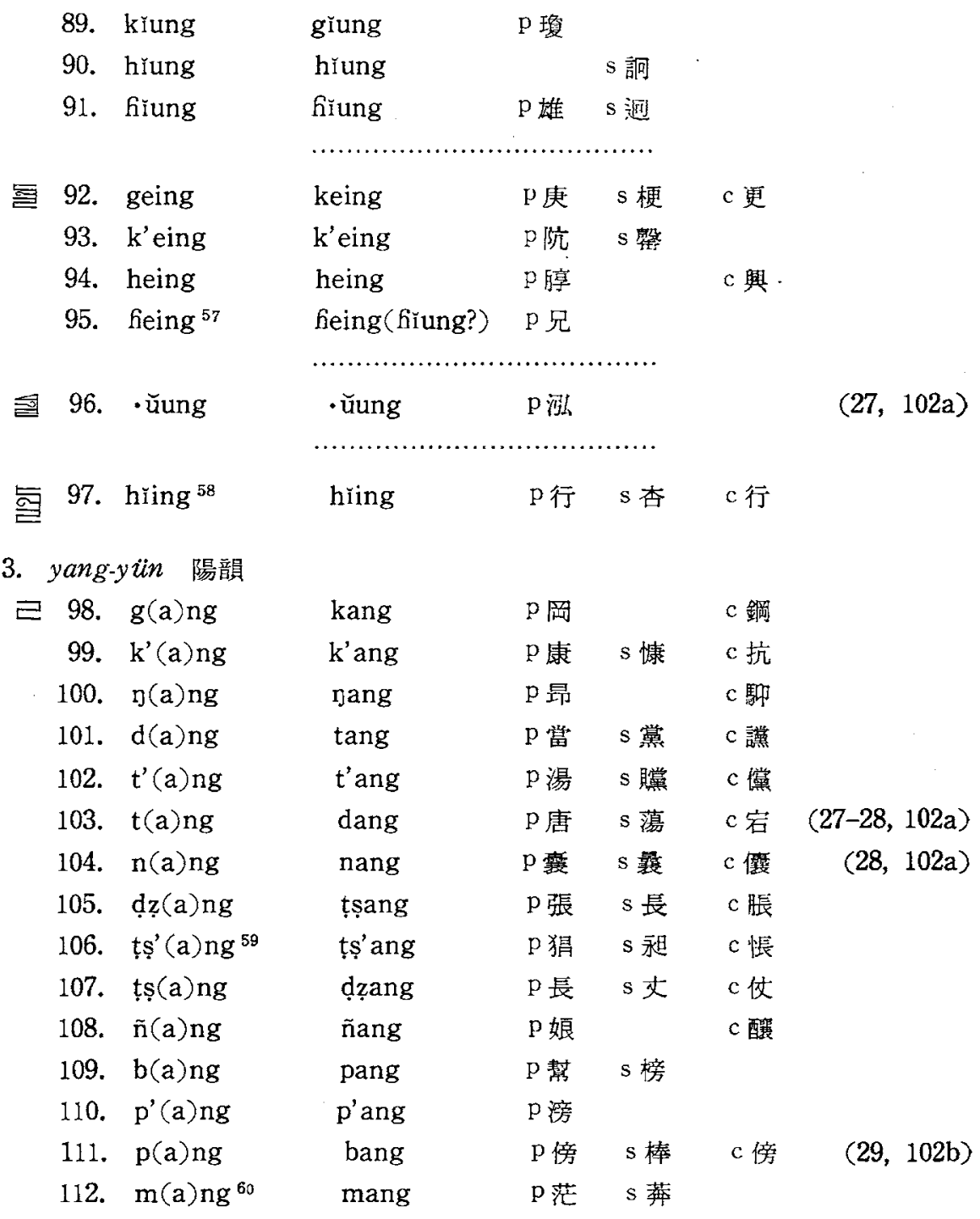

hẻung; Ligeti, op. cit., 熊 hüin. Cheng Tsai-fa makes no distinction between Nos. 27-42 and Nos. 87-91.

57 Hattori gives this as hüing (op. cit., p. 43). 58 The $P C H$ and some other inscriptions give $\lesssim$. Cf. Cheng Tsai-fa, op. cit., p.
950 .

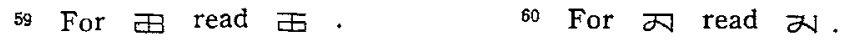




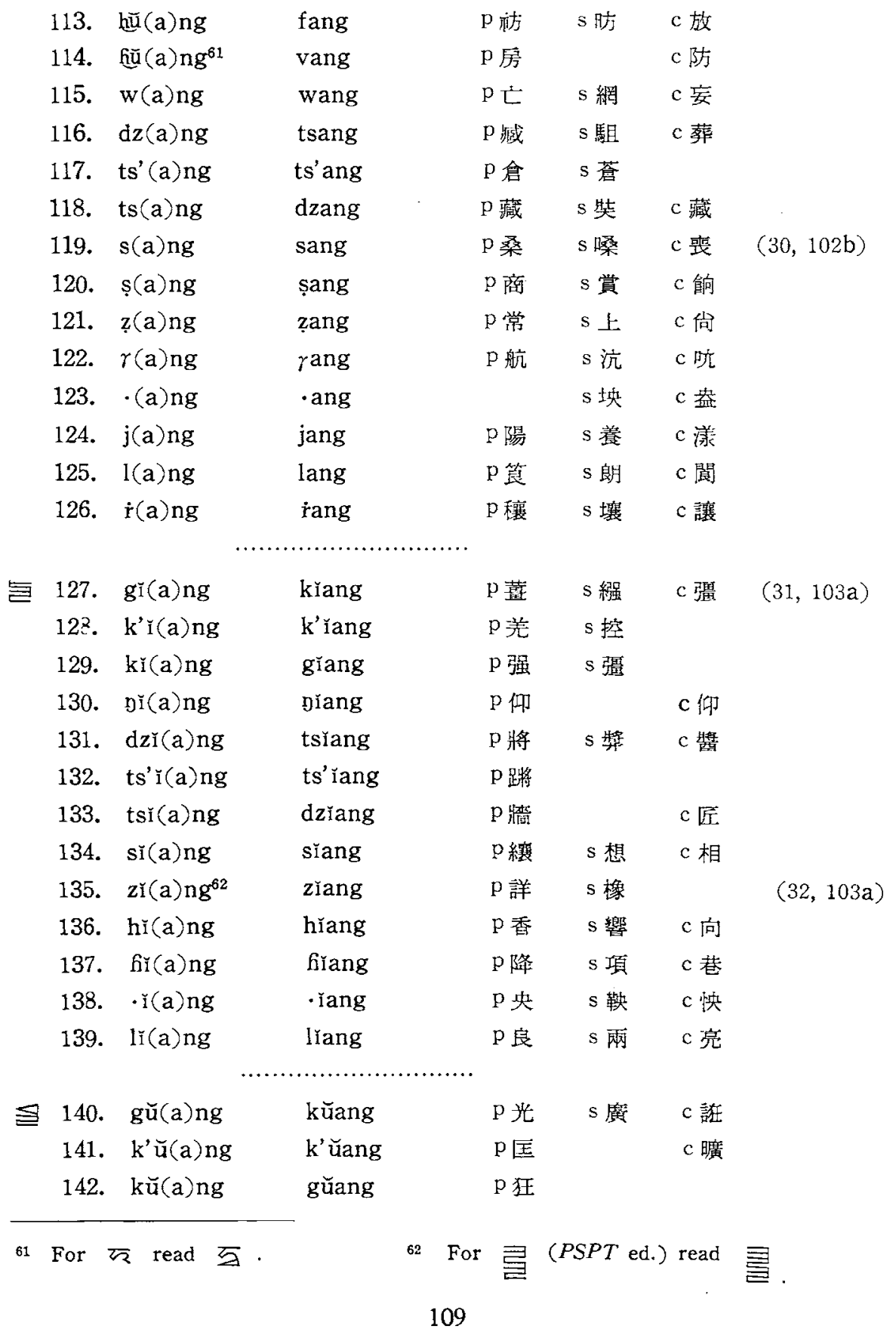




\begin{tabular}{|c|c|c|c|c|c|c|c|}
\hline & 143. & $d z \breve{u}(a) n g$ & ț̣̦ŭang & $\mathrm{p}$ 椿 & & & \\
\hline & 144. & $t s^{\prime} \breve{u}(a) n g$ & țṣ' ŭang & p 密 & & & $(33,103 b)$ \\
\hline & 145. & țșu $(a) n g$ & ḍ̨ŭang & $\mathrm{p}$ 憧 & & c 撞 & \\
\hline & 146. & șŭ(a)ng & șŭang & $\mathrm{p}$ 雙 & & & \\
\hline & 147. & $h \breve{u}(a) n g$ & hǔang & $\mathrm{p}$ 荒 & s 慌 & & \\
\hline & 148. & $\cdot \breve{u}(a) n g$ & - ŭang & $\mathrm{p}$ 汪 & s 枉 & $\mathrm{c}$ 汪 & \\
\hline & 149. & $\mathrm{y} \breve{u}(\mathrm{a}) \mathrm{ng}^{63}$ & yŭang & $\mathrm{p}$ 王 & s 往 & $\mathrm{c}$ 迋 & \\
\hline & 150. & lü $(a) n g$ & lŭang & $\mathrm{p}$ 㴰 & & & \\
\hline 粱 & 151. & $\mathrm{~d} z h(\mathrm{a}) \mathrm{ng}$ & ț̣̦png 64 & $\mathrm{p}$ 莊 & & $\mathrm{c}$ 㣟 & \\
\hline & 152. & țș'h(a)ng & țș'png & $\mathrm{p}$ 創 & $\mathrm{s}$ 教 & c 旅 & \\
\hline & 153. & $\operatorname{tss} h(a) n g$ & dụpng & $\mathrm{p}$ 新 & & $\mathrm{c}$ 狀 & \\
\hline & 154. & $\operatorname{shh}(a) n g$ & șpng & $\mathrm{p}$ 霜 & $\mathrm{s}$ 爽 & & $(34,103 b)$ \\
\hline 沓 & 155. & rọng & $\gamma$ ong & $\mathrm{p}$ 㯇 & $\mathrm{s}$ 晃 & $\mathrm{c}$ 攩 & \\
\hline 을 & 156. & hŭeng & fiǔeng & & s悦 & $\mathrm{c}$ 况 & \\
\hline
\end{tabular}

4. chih-yün 支韻

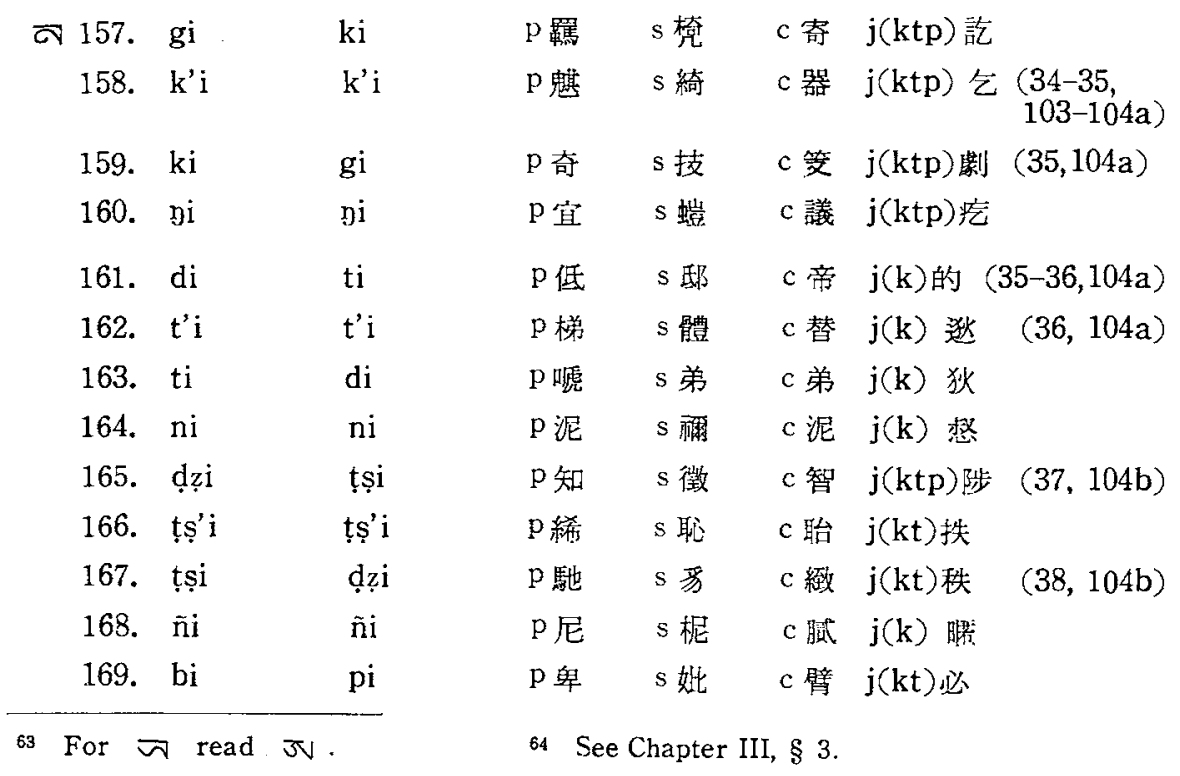




\begin{tabular}{|c|c|c|c|c|c|c|c|}
\hline 170. & $p^{\prime} i$ & $p^{\prime} i$ & $\mathrm{p}$ 絽 & s 諀 & $\mathrm{c}$ 譬 & $\mathrm{j}(\mathrm{k})$ 匹 & \\
\hline 171. & $\mathrm{pi}$ & $\mathrm{bi}$ & $\mathrm{p}$ 陴 & s 婢 & $\mathrm{c}$ 鼻 & $\mathrm{j}(\mathrm{kt})$ 䣇 & $(39,105 a)$ \\
\hline 172. & $\mathrm{mi}$ & $\mathrm{mi}$ & $\mathrm{p}$ 彌 & s 湖 & c㵀 & $\mathrm{j}(\mathrm{kt})$ 蜜 & \\
\hline 173. & $\mathrm{hi}^{65}$ & $\mathrm{fi}$ & $\mathrm{p}$ 菲 & s菲 & c 沸 & & \\
\hline 174. & $\mathrm{fii}^{66}$ & $\mathrm{vi}$ & $\mathrm{p}$ 肥 & & $c$ 㧈 & & \\
\hline 175. & wi & wi & $\mathrm{p}$ 微 & s 尾 & $\mathrm{c}$ 末 & & \\
\hline 176. & $\mathrm{~d} z \mathrm{i}$ & tsi & 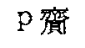 & $\mathrm{s}$ 濟 & $\mathrm{c}$ 䨎 & $\mathrm{j}(\mathrm{kp})$ 覒 & $(39-40,105 a)$ \\
\hline 177. & ts'i & $t^{\prime} \dot{i}$ & $\mathrm{p}$ 妻 & $s$ 泚 & c 砌 & $j(k t p) t$ & $(40,105 a)$ \\
\hline 178. & tsi & $\mathrm{dzi}$ & $\mathrm{p}$ 齊 & $\mathrm{s}$ 蒜 & $\mathrm{c}$ 碎 & $\mathrm{j}(\mathrm{ktp})$ 疾 & 1 \\
\hline 179. & si & si & $\mathrm{p}$ 西 & $\mathrm{s}$ 洗 & $\mathrm{c}$ 細 & $\mathrm{j}(\mathrm{kt})$ 悉 & \\
\hline 180. & $z i$ & $\mathrm{zi}$ & & & & $\mathrm{j}(\mathrm{ktp})$ 席 & \\
\hline 181. & și & și & p 絁 & $\mathrm{s}$ 弛 & c 翅 & $\mathrm{j}(\mathrm{kt})$ 失 & $(40-41,105 a-b)$ \\
\hline 182. & $z i$ & $\mathrm{zi}$ & $\mathrm{p}$ 時 & $\mathrm{s}$ 是 & c豉 & $\mathrm{j}(\mathrm{kp})$ 石 & $(41,105 \mathrm{~b})$ \\
\hline 183. & hi & hi & $\mathrm{p}$ 犠 & $\mathrm{s}$ 喜 & $\mathrm{c}$ 戲 & $\mathrm{j}(\mathrm{tp})$ 赩 & \\
\hline 184. & $\cdot \mathrm{i}$ & $\cdot \dot{i}$ & p 渏 & s 倚 & c 懿 & $j(t p) 己$ & $(41-42,105 b)$ \\
\hline 185. & $\cdot \mathrm{ji}$ & $\mathrm{xi}$ & $\mathrm{p}$ 伊 & & $\mathrm{c}$ 緢 & $j(t p)$ 壹 & $(42,105 b)$ \\
\hline 186. & $\mathrm{ji}$ & $\mathrm{ji}$ & $\mathrm{p}$ 移 & s 酏 & c 易 & $\mathrm{j}(\mathrm{kt})$ 逸 $(42$ & $-43,105 b-106 a)$ \\
\hline 187. & li & li & P離 & $\mathrm{s}$ 遷 & $\mathrm{c}$ 署 & $j(k t)$ 栗 $^{67}$ & $(43,106 a)$ \\
\hline 188. & $\ddot{\mathbf{r} i}$ & $\ddot{\mathrm{r}} \mathrm{i}$ & $\mathrm{p}$ 兒 & s 爾 & $c=$ & $j(t p)$ 日 & \\
\hline
\end{tabular}

厉 189. dzh $\mathrm{i}$

țș $\mathbf{1}^{68}$

$\mathrm{p}$ 藥 $\mathrm{s}$ 㳯 $\mathrm{c}$ 裁 $\mathrm{j}(\mathrm{kp})$ 櫛

$(44,106 a)$

190. țș'hi

țș' I

$\mathrm{p}$ 差

$\mathrm{s}$ 測

191. țșhi

dẹ 1

$\mathrm{p}$ 繁 $\mathrm{s}$ 士 $\mathrm{c}$ 事

192. $\mathrm{d} z h \mathrm{i}$

ts I

$\mathrm{p}$ 貲 $\mathrm{s}$ 紫 $c$ 積

193. ts' $h \mathrm{i}$

ts' I

$\mathrm{p}$ 政 $\mathrm{s}$ 此 $\mathrm{c}$ 刺

194. ts $h \mathrm{i}$

$\mathrm{dz}$ I

$p$ 慈

c 字

195. shi

$\mathrm{p}$ 思

賜

(44-45, 106a-b)

196. $z h \mathrm{i}$

$\mathrm{p}$ 詞 $\mathrm{s}$ 岂 $\mathrm{c}$ 寺

$(45,106 \mathrm{~b})$

65 For $\overline{2}$ read $\overline{3}$.

66 For 5 read $\overline{2}$.

67 The character 糜 in the $j u$-sheng group of the PSPT edition must be corrected to 歷, because in the Ch'ien-lung manuscript of the $M K T Y$, the last stroke of this character should be lacked to avoid the identity with 弘厤, the first name of the Emperor Ch'ien-lung. Cf. Ozaki, op. cit., p. 164.

68 For $\boxplus$ read $\varpi$. 


\begin{tabular}{|c|c|c|c|c|c|c|c|c|}
\hline 197. & $s^{l} l_{l i}$ & Ș I & $\mathrm{p}$ 䈣 & $\mathrm{s}$ 犀 & c 歌 & $j(t p)$ & 瑟 & \\
\hline 六 198. & gei & kei & $\mathrm{p}$ 鵎 & & c 話 & $j(k t)$ & 吉 & \\
\hline 199. & k'ei & k'ei & $\mathrm{p}$ 奚 & s 啓 & c 契 & $j(t)$ & 䝟 & \\
\hline 200. & kei & gei & p站 & & & & & \\
\hline 201. & hei & hei & $\mathrm{p}$ 䤀 & & & & & $(46,10 \circ b)$ \\
\hline 202. & fiei & ḩei & $\mathrm{p}$ 奚 & $\mathrm{s}$ 徯 & c 系 & $j(k t)$ & 檄 & \\
\hline 의 203 . & gue & $\mathrm{ku} \varepsilon$ & $\mathrm{p}$ 鸽 & $\mathrm{s}$ 詭 & c 媿 & $\mathrm{j}(\mathrm{k})$ & 國 & \\
\hline 204. & k'u $\varepsilon$ & $k^{\prime} u \varepsilon$ & $\mathrm{p}$ 㓺 & $\mathrm{s}$ 跍 & c 喟 & & & \\
\hline 205. & $\mathrm{ku} \varepsilon$ & gue & $\mathrm{p}_{\text {迬 }}$ & $\mathrm{s}$ 㻊 & c 厠 & & & \\
\hline 206. & $\mathrm{du} \varepsilon$ & tue & $\mathrm{p}$ 磓 & & c 對 & & & \\
\hline 207. & $t^{\prime} u \varepsilon$ & $t^{\prime} u \varepsilon$ & $\mathrm{p}$ 藩 & s 煺 & $c$ 娔 & & & \\
\hline 208 & tue & $\mathrm{du} \varepsilon$ & $\mathrm{p}$ 䫋 & & c 見 & & & $(47,107 a)$ \\
\hline 209. & nu $\varepsilon$ & nu $\varepsilon$ & $\mathrm{p}$ 捼 & $\mathrm{s}$ 餧 & $\mathrm{c}$ 內 & & & \\
\hline 210. & ḍ̨u $\varepsilon$ & țșu $\varepsilon$ & $\mathrm{p}$ 追 & $\mathrm{s}$ 捶 & $\mathrm{c}$ 㨫 & & & \\
\hline 211. & 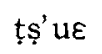 & țş'u $u$ & $\mathrm{p}$ 吹 & & $\mathrm{c}$ 吹 & & & \\
\hline 212. & ț̣̦u & $d z u \varepsilon$ & $\mathrm{p}$ 篇 & & c 鍾 & & & \\
\hline 213. & $\tilde{\text { nu }}$ & $\tilde{\text { ñu }} \varepsilon$ & & & c 諉 & & & \\
\hline 214. & bu $\varepsilon$ & pu $\varepsilon$ & p陂 & $\mathrm{s}$ 彼 & c 賈 & $\mathrm{j}(\mathrm{kt})$ & 碧 & \\
\hline 215. & p'uع & pu' $\varepsilon$ & p披 & $\mathrm{s}$ 㱟 & $\mathrm{c}$ 帔 & $\mathrm{j}(\mathrm{k})$ & 堛 & $(47-48,107 a)$ \\
\hline 216. & pu $\varepsilon$ & bue & $\mathrm{p}$ 皮 & s 被 & c 铰 & $\mathrm{j}(\mathrm{kt})$ & 㟲 & $(48,107 a)$ \\
\hline 217. & mue & mu $\varepsilon$ & $\mathrm{p}$ 酶 & $\mathrm{s}$ 磨 & c 媚 & $\mathrm{j}(\mathrm{kt})$ & 密 & \\
\hline 218. & $\mathrm{~d} z \mathrm{u} \varepsilon$ & tsue & $\mathrm{p}$ 劑 & $\mathrm{s}$ 觜 & c 醉 & & & \\
\hline 219. & ts'ue & ts'uع & p 崔 & $\mathrm{s}$ 皠 & $c$ 秋 & & & \\
\hline 220. & tsue & $\mathrm{d} z u \varepsilon$ & $\mathrm{p}$ 摧 & $\mathrm{s}$ 章 & $\mathrm{c}$ 萃 & & & \\
\hline 221. & sue & sue & $\mathrm{p}$ 眭 & $\mathrm{S}$ 髓 & $\mathrm{c}$ 選 & & & $(49,107 b)$ \\
\hline 222. & $z \mathrm{u} \varepsilon$ & $z \mathrm{u} \varepsilon$ & $\mathrm{p}$ 隨 & & c 逐 & & & \\
\hline 223. & șu $\varepsilon$ & șue & & $\mathrm{s}$ 水 & $\mathrm{c}$ 稅 & & & \\
\hline 224. & zue & zu $\varepsilon$ & $\mathrm{p}$ 垂 & $\mathrm{s}$ 華 & c 睡 & & & \\
\hline 225. & hu $\varepsilon$ & hus & $\mathrm{p}$ 灰 & $\mathrm{s}$ 賄 & $\mathrm{c}$ 臟 & & & \\
\hline 226. & ru $\varepsilon$ & $\gamma \mathrm{u} \varepsilon$ & $\mathrm{p}$ 迴 & $\mathrm{s}$ 魏 & c 會 & $\mathrm{j}(\mathrm{k})$ & 或 & \\
\hline 227. & $\cdot \mathrm{u} \varepsilon$ & $\cdot \mathrm{u} \varepsilon$ & $\mathrm{p}$ 逶 & $\mathrm{s}$ 委 & $c$ 尉 & $\mathrm{j}(\mathrm{k})$ & 域 & $(49-, 50107 \mathrm{~b})$ \\
\hline 228. & yu & yu & P色 & s 硊 & $c$ 僞 & & & $(50,107 \mathrm{~b})$ \\
\hline
\end{tabular}




\begin{tabular}{|c|c|c|c|}
\hline 29. Iu $\varepsilon$ & lue & $\mathrm{p}$ 覇 & $\mathrm{s}$ 累 \\
\hline 230. ru & rue & $\mathrm{p}$ 茗 & $\mathrm{s}$ 警 \\
\hline
\end{tabular}

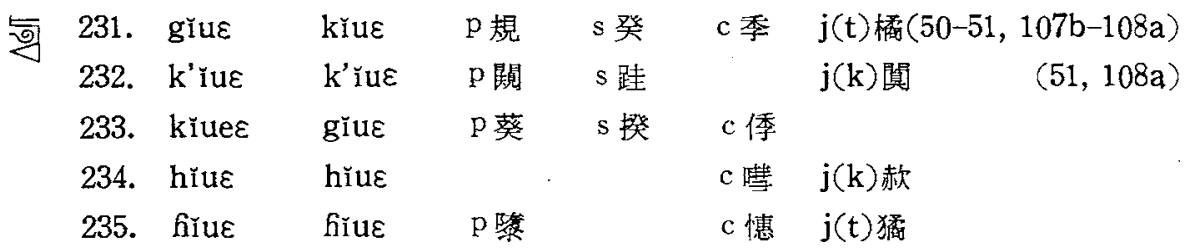

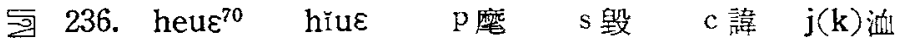

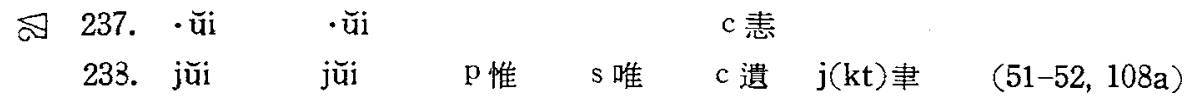

5. yü-yün 魚韻

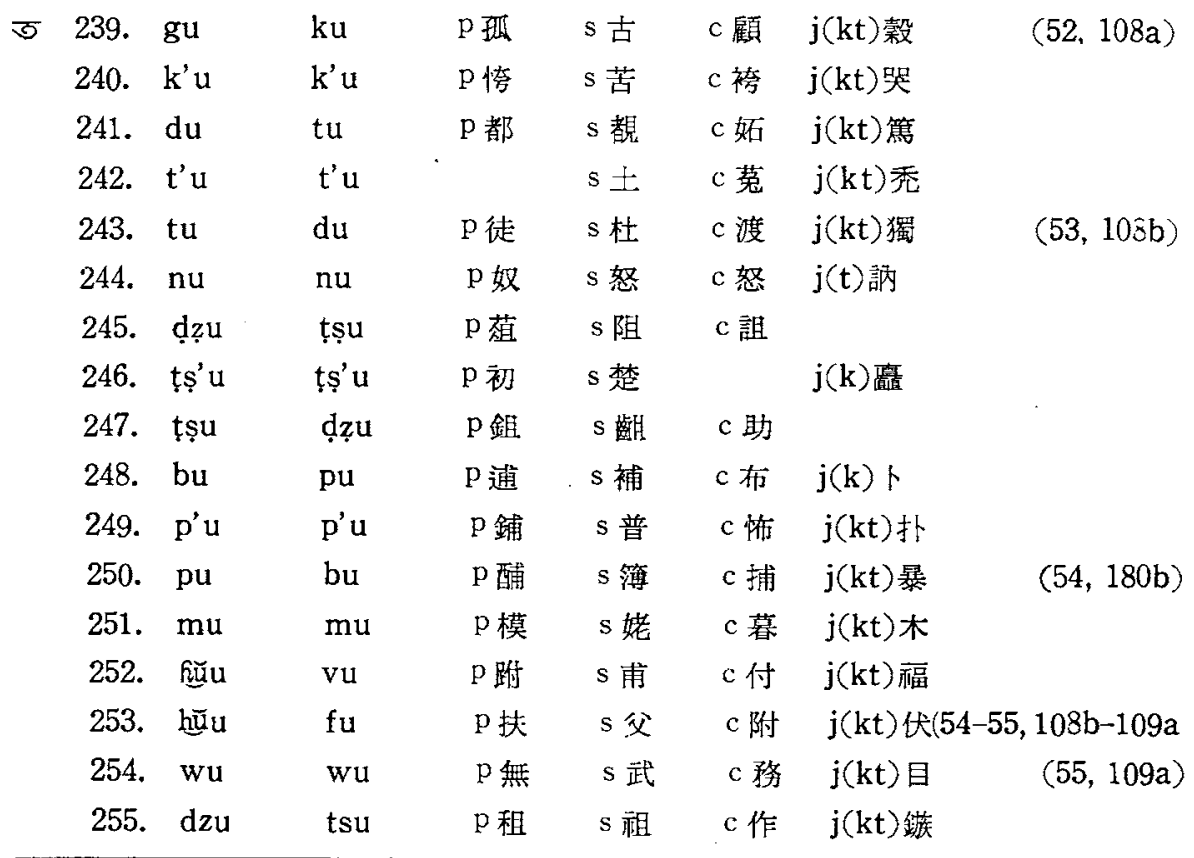

69 The s. and c. groups are to be reversed.

70 For $ᄌ$ read $\overline{2}$. 


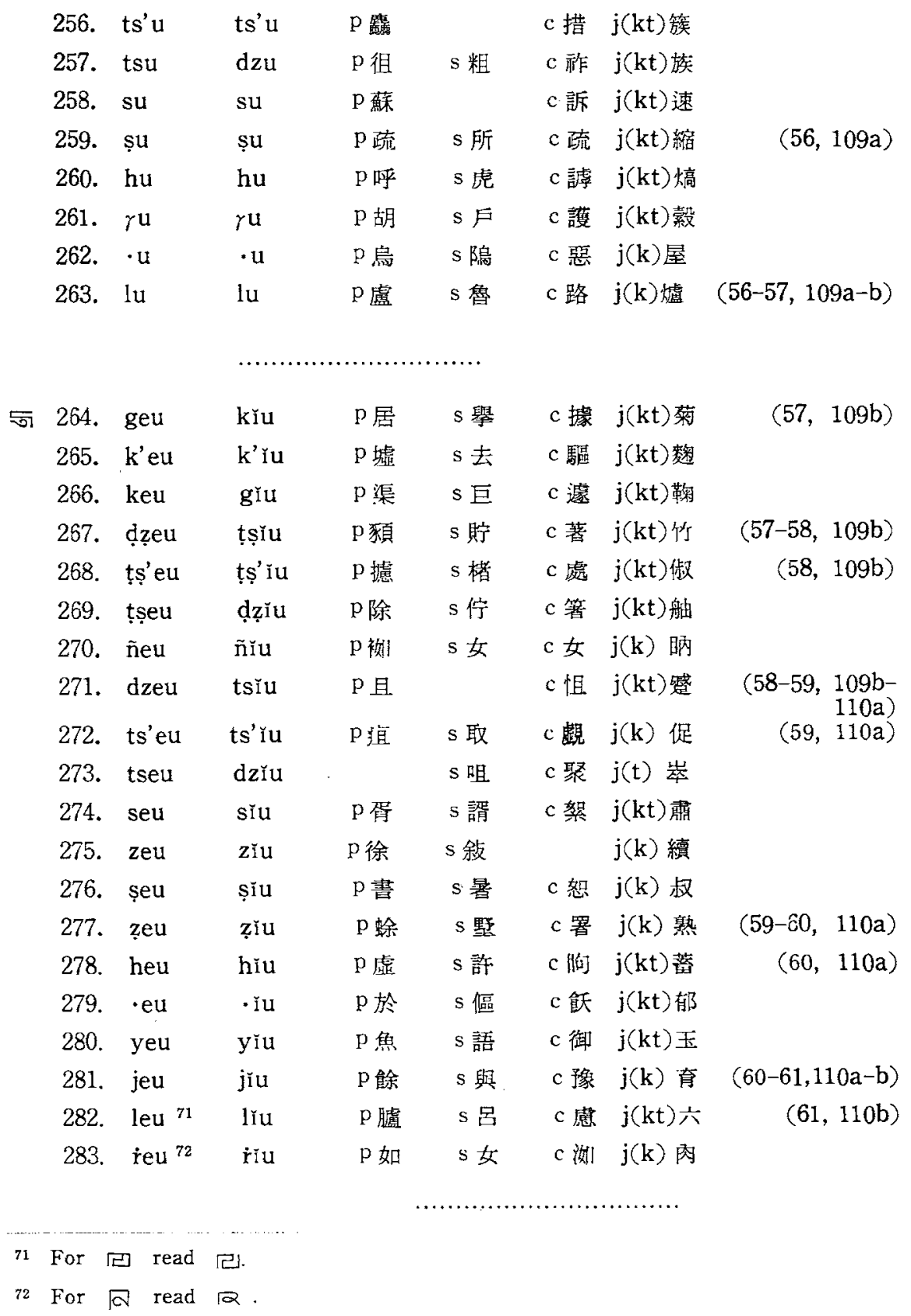




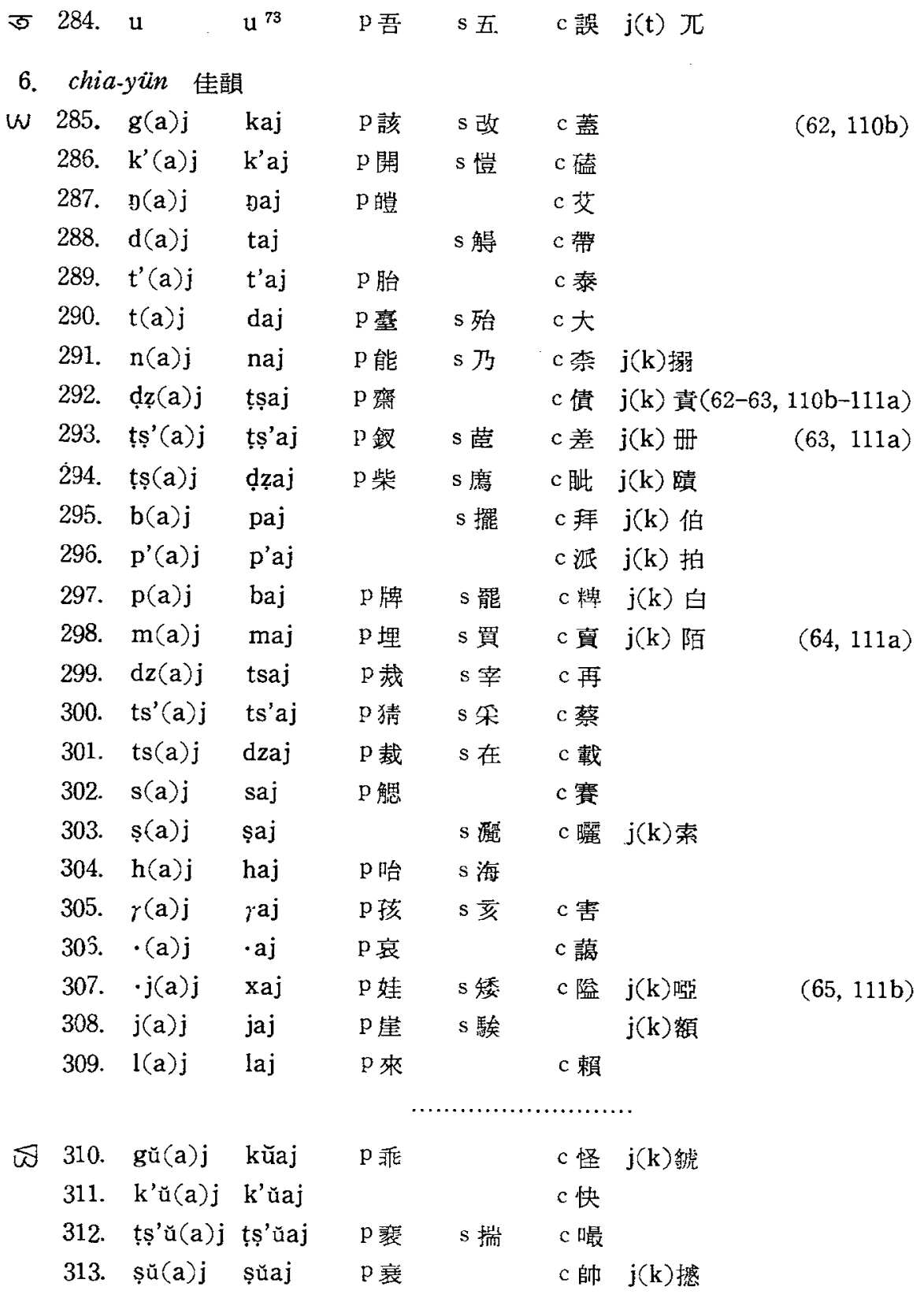

73 This group ought to belong to the Nos. 239-263 group. 


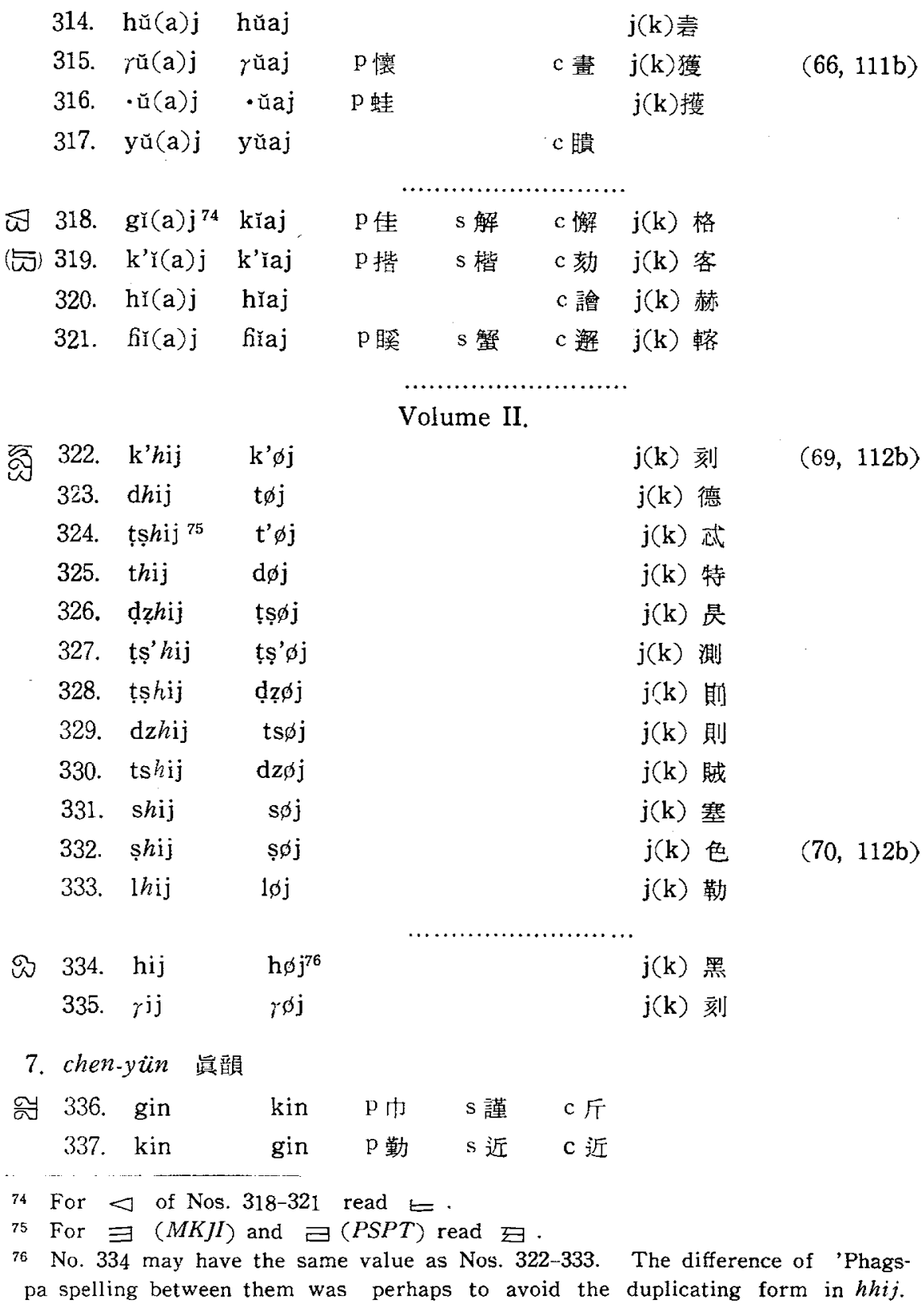




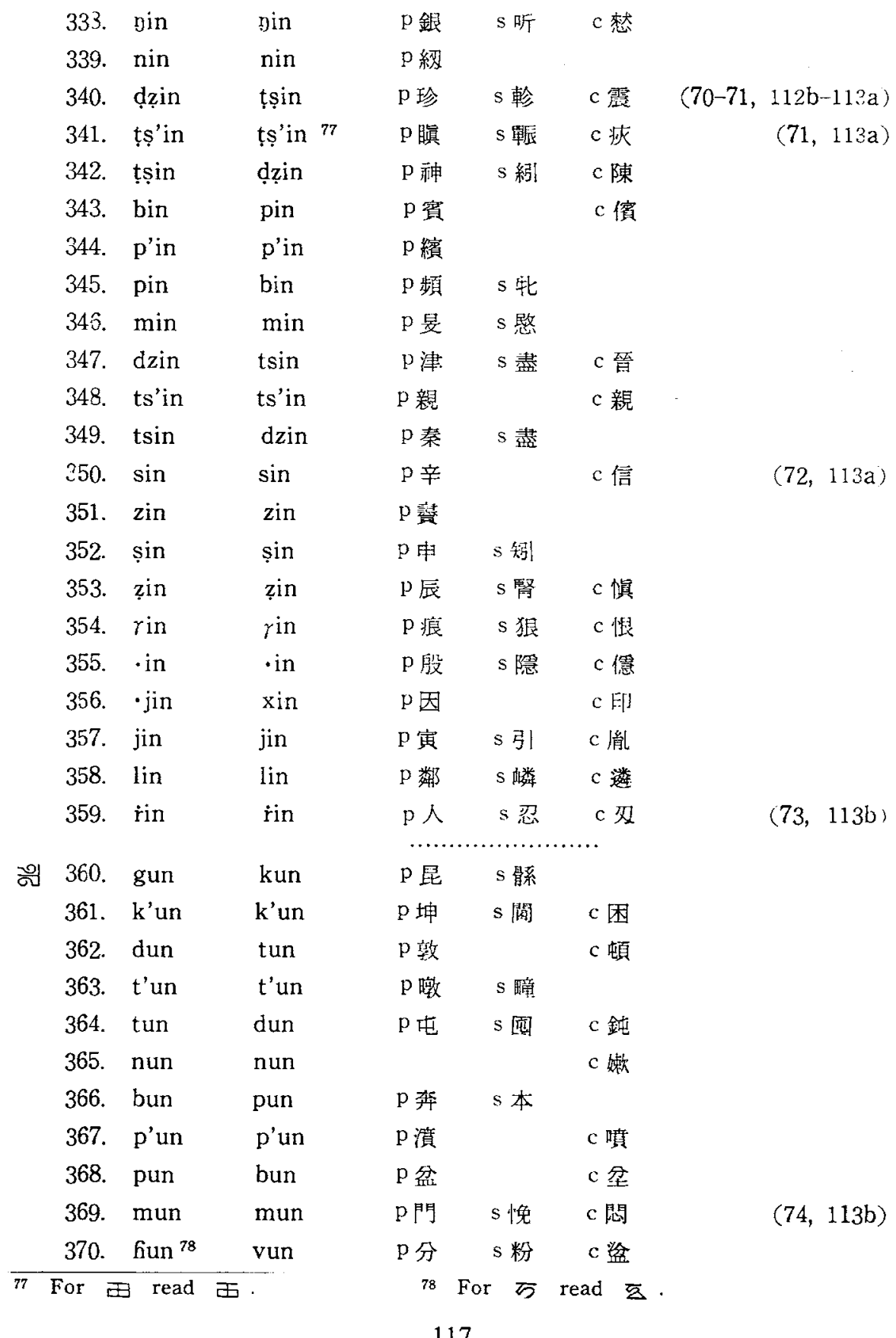




\begin{tabular}{|c|c|c|c|c|c|c|}
\hline & 371. hun ${ }^{79}$ & fun & $\mathrm{p}$ 添 & $\mathrm{s}$ 憤 & c 分 & \\
\hline & 372. wun 80 & wun & $p$ 交 & s吻 & $\mathrm{c}$ 問 & \\
\hline & 373. dzun & tsun & $\mathrm{p}$ 拿 & s 椐 & c 捘 & \\
\hline & 374. ts'un & ts'un & $p$ 村 & $\mathrm{s}$ 忖 & $c$ 寸 & \\
\hline & 375. tsun & dzun & $\mathrm{p}$ 存 & $\mathrm{s}$ 鐔 & & \\
\hline & 376. sun & sun & $\mathrm{p}$ 孫 & $\mathrm{s}$ 損 & $\mathrm{c}$ 巽 & $(75,114 a)$ \\
\hline & 377. hun & hun & $\mathrm{p}$ 昏 & & & \\
\hline & 378. run & run & $\mathrm{p}$ 魂 & s 混 & c 窇 & \\
\hline & 379. $\cdot$ un & - un & p 溫 & $\mathrm{s}$ 穏 & & \\
\hline 诵 & 380. lun & lun & $\mathrm{p}$ 論 & & $c$ 論 & \\
\hline & 381. geun & kĩun & $\mathrm{p}$ 君 & & $c$ 捰 & \\
\hline & 382. k'eun & k'iun & $\mathrm{p}$ 困 & & & \\
\hline & 383. keun & gĩun & $\mathrm{p}$ 群 & $\mathrm{s}$ 䆖 & c 郡 & \\
\hline & 384. ḍeun & ț̣̦iun & $\mathrm{p}$ 屯 & s 準 & $\mathrm{c}$ 橔 & \\
\hline & 385. țş'eun & ț̣̦’iun & $\mathrm{p}$ 春 & $\mathrm{s}$ 蛋 & & \\
\hline & 386. ț̣̦eun & dẓ̂uun & $\mathrm{p}$ 勈 & $\mathrm{s}$ 盾 & $\mathrm{c}$ 順 & $(76,-81)$ \\
\hline & 387. dzeun & tš̃un & $\mathrm{p}$ 潭 & & $\mathrm{c}$ 儶 & \\
\hline & 388. ts'eun & ts'ǐun & $\mathrm{p}$ 逡 & & & . \\
\hline & 389. seun & sĩun & $\mathrm{p}$ 䓪 & $\mathrm{s}$ 笋 & c 峻 & \\
\hline & 390. zeun & zĭun & $\mathrm{p}$ 旬 & & c 徝 & \\
\hline & 391. șeun & ș̆un & & & c 舜 & \\
\hline & 392. zeun & žrun & $\mathrm{p}$ 醇 & & & \\
\hline & 393. heun & hĩun & $\mathrm{p}$ 薰 & & 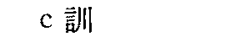 & \\
\hline & 394. jeun & jŭun & $\mathrm{p}$ 约 & s $\exists^{\exists}$ & & \\
\hline & 395. leun & līun & p 淪 & & & \\
\hline & 396. reun & řĭun & $\mathrm{p}$ 特 & s 䖨 & c 閏 & $(77,-)$ \\
\hline 蒆 & 397. $\mathrm{g} h \mathrm{in}$ & $k ø n$ & $\mathrm{p}$ 根 & & c 宠 & \\
\hline & 398. k'hin & $k^{\prime} ø n$ & & s 荱 & & \\
\hline & 399. t' $h$ in & $t^{\prime} \phi n$ & $\mathrm{p}$ 吞 & & c 褪 & \\
\hline & 400. dzhin & 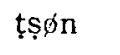 & $\mathrm{p}$ 㯃 & & & \\
\hline & 401. țș'hin & $t s^{\prime} \phi n$ & & & $\mathrm{c}$ 襯 & \\
\hline 7 & 不 & & 80 & or 厉 & 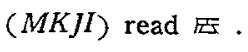 & \\
\hline
\end{tabular}




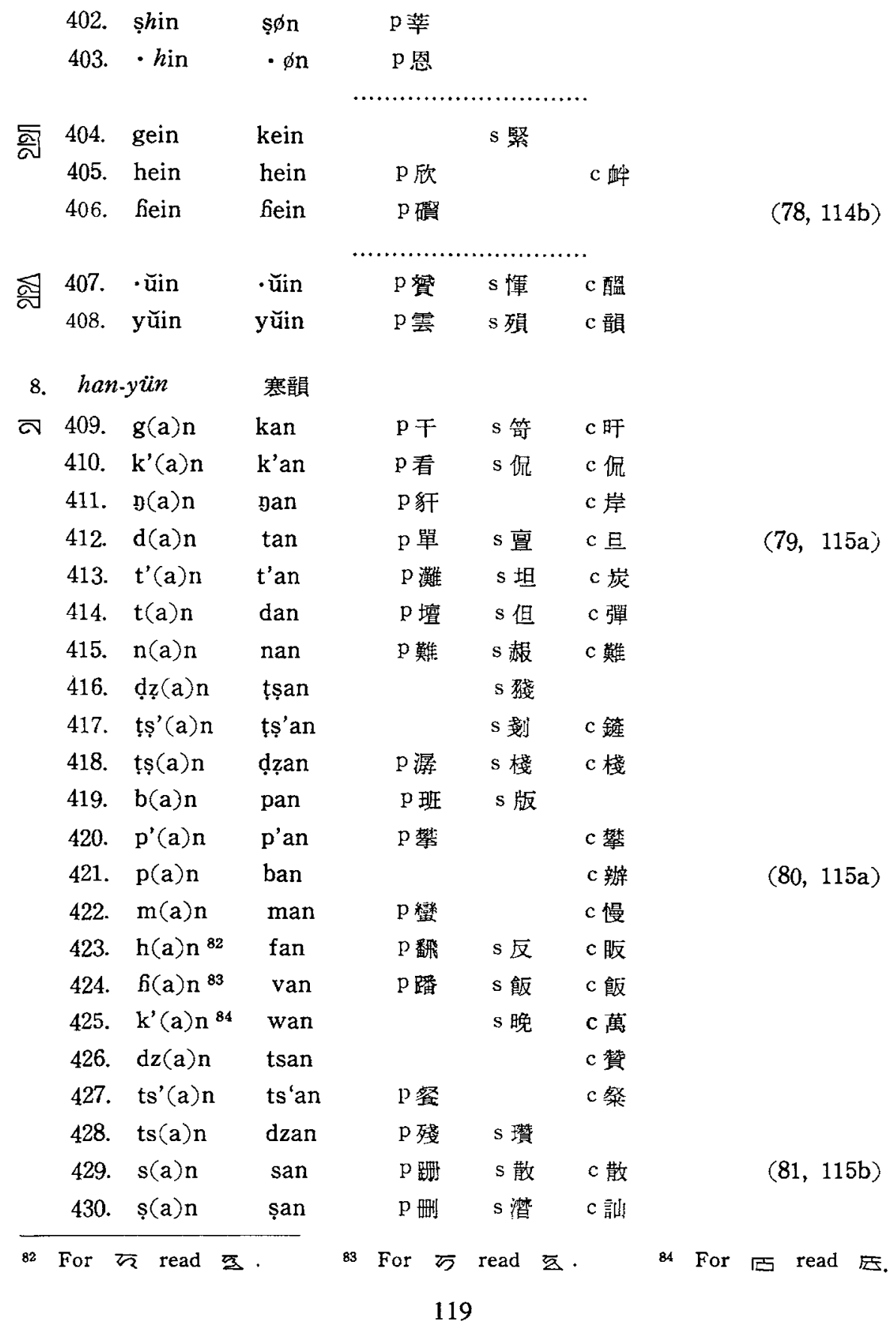




\begin{tabular}{|c|c|c|c|c|c|c|c|}
\hline 431. & $h(a) n$ & han & & $\mathrm{s}$ 眾 & c 漢 & & \\
\hline 432. & $\gamma(\mathrm{a}) \mathrm{n}$ & ran & $\mathrm{p}$ 寒 & $\mathrm{s}$ 早 & $\mathrm{c}$ 翰 & & \\
\hline 433. & - (a)n & - an & $\mathrm{p}$ 安 & & $\mathrm{c}$ 按 & & \\
\hline 434. & $\cdot j(a) n$ & xan & $\mathrm{p}$ 殷 & & $\mathrm{c}$ 悬 & & \\
\hline 435. & $j(a) n$ & jan & p 顏 & $\mathrm{s}$ 眼 & c 鵳 & & \\
\hline 436. & $1(a) n$ & $\operatorname{lan}$ & $\mathrm{p}$ 闌 & $\mathrm{s}$ 嬾 & $\mathrm{c}$ 爛 & & \\
\hline 变 437 . & on & $\mathrm{ON}$ & $\mathrm{p}$ 梳 & & $c$ 玩 & & \\
\hline 438. & gon & kON & $\mathrm{p}$ 官 & s 管 & c 貫 & & $(82,115 b)$ \\
\hline 439. & $\mathrm{k}^{\prime} \mathrm{o} n$ & $\mathrm{k}^{\prime} \mathrm{ON}$ & p寬 & s 款 & & & \\
\hline 440. & $\mathrm{de \varphi n}$ & ton & p 端 & $s$ 短 & c 鍛 & & \\
\hline 441. & $\mathbf{t}^{\prime} \wp n$ & t'JN & $\mathrm{p}$ 湍 & $\mathrm{s}$ 曈 & $c$ 象 & & \\
\hline 442. & $\operatorname{ton} n$ & $\mathrm{~d} \partial \mathrm{N}$ & p團 & s 斷 & c 段 & & \\
\hline 443. & nọn & noN & & s 暖 & c 瀷 & & \\
\hline 444. & bop $n$ & por & p 播 & & $\mathrm{c}$ 牛 & & \\
\hline 445. & $p^{\prime} \circ n$ & p'ox & $\mathrm{p}$ 潘 & & c 制 & & \\
\hline 446. & $\mathrm{pop} n$ & box & p 槃 & s 件 & $\mathrm{c}$ 叛 & $(82-83$ & $115 b-116 a)$ \\
\hline 447. & $\operatorname{mon}$ & $\operatorname{mox}$ & $\mathrm{p}$ 䁧 & $\mathrm{s}$ 滿 & c 縵 & & $(83,116 a)$ \\
\hline 448. & $\mathrm{~d} z o n$ & tson & $\mathrm{p}$ 鑽 & $\mathrm{s}$ 纂 & $\mathrm{c}$ 鑽 & & \\
\hline 449. & ts'on & $t^{\prime} s^{\prime} \mathrm{N}$ & & & $\mathrm{c}$ 爺 & & \\
\hline 450. & $\operatorname{tso} n$ & dzon & $\mathrm{p}$ 攢 & & $\mathrm{c}$ 攢 & & \\
\hline 451. & $\operatorname{son} n$ & son & p 酸 & $\mathrm{s}$ 算 & c 籍 & & \\
\hline 452. & họn & haN & $\mathrm{p}$ 歡 & & $\mathrm{c}$ 㬇 & & \\
\hline 453. & rọn & rox & $\mathrm{p}$ 桓 & s 緩 & c換 & & \\
\hline 454. & $\cdot \mathrm{q}^{n}$ & $\cdot 2 N$ & $\mathrm{p}$ 宛员 & $\mathrm{s}$ 盌 & c 恀 & & \\
\hline 455. & $\log n$ & lon & $\mathrm{p}$ 鑾絭 & $\mathrm{s}$ 邲 & $\mathrm{c}$ 筬 & & $(84,116 a)$ \\
\hline
\end{tabular}

刃 456. $\mathrm{g} \check{\mathrm{u}}(\mathrm{a}) \mathrm{n}$ kŭan p閶 c 慣 457. dqŭ $(a) n$ țșŭan $p$ 跧

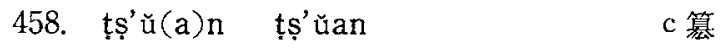

459. ț̣̆u (a)n ḍŭan s 撰 $c$ 饌

460. $r \breve{u}(a) n \quad \gamma \breve{u} a n \quad p$ 還 $s$ 脘 $c$ 患

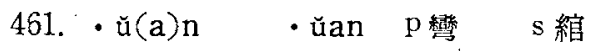




\begin{tabular}{|c|c|c|c|c|c|c|c|}
\hline & 462. & $t^{\prime} \cdot \breve{u}(a) n^{8 \bar{s}}$ & yŭan & $\mathrm{p}$ 碩 & & & \\
\hline 氞 & 463. & $g \check{l}(a) n$ & kian & $\mathrm{p}$ 間 & $\mathrm{s}$ 簡 & c 襇 & $(84-85,116 a-b)$ \\
\hline & 464. & $k^{\prime} i(a) n$ & k'ǐan & $\mathrm{p}$ 唕 & & & $(85,116 \mathrm{~b})$ \\
\hline & 465. & $h_{1}(a) n$ & fịan & $\mathrm{p}$ 閑 & $\mathrm{s}$ 䦔 & $\mathrm{c}$ 莧 & \\
\hline 9. & hsie & $n-y \ddot{u n}$ 先韻 & & & & & \\
\hline ন & 466. & gen & $\mathrm{k} \varepsilon \mathrm{n}$ & $\mathrm{p}$ 懍 & $\mathrm{s}$ 寒 & c 建 & \\
\hline & 467. & $\mathrm{k}^{\prime} \varepsilon \mathrm{n}$ & $\mathrm{k}^{\prime} \varepsilon \mathrm{n}$ & $\mathrm{p}$ 缺 & & c 譴 & \\
\hline & 468. & $\mathrm{k} \varepsilon \mathrm{n}$ & gen & $\mathrm{p}$ 乾 & s 件 & c 健 & \\
\hline & 469. & $\eta \varepsilon n$ & yعn & $\mathrm{p} \overrightarrow{\overrightarrow{\bar{⿳}}}$ & $\mathrm{~s}$ 獻 & $\mathrm{c}$ & \\
\hline & 470. & $\mathrm{~d} \varepsilon \mathrm{n}$ & $\operatorname{t\varepsilon n}$ & $\mathrm{p}$ 顛 & $s$ 典 & c 殿 & \\
\hline & 471. & t' $\varepsilon n$ & $t^{\prime} \varepsilon n$ & $\mathrm{p}$ 天 & $\mathrm{s}$ 腆 & $\mathrm{c}$ 瑱 & \\
\hline & 472. & $\mathrm{t} \varepsilon \mathrm{n}$ & $d \varepsilon n$ & $\mathrm{p}$ 田 & s殁 & c 電 & $(86,116 \mathrm{~b})$ \\
\hline & 473. & $\mathrm{n} \varepsilon \mathrm{n}$ & nen & $\mathrm{p}$ 季 & $\mathrm{s}$ 撚 & $\mathrm{c}$ 睍 & \\
\hline & 474. & d̨̦̣n & ţ̦̦ূn & $\mathrm{p}$ 邅 & & $\mathrm{c}$ 驏 & \\
\hline & 475. & ț̣̦દn & ḍ̨̣n & $\mathrm{p}$ 緾 & & & \\
\hline & 476. & $\mathrm{p} \varepsilon n$ & ben & $\mathrm{p}$ 嗝 & $\mathrm{s}$ 辫 & $c$ 下 & \\
\hline & 477. & men & $\mathrm{m} \varepsilon \mathrm{n}$ & $\mathrm{p}$ 眠 & $\mathrm{s}$ 緬 & $c$ 麵 & \\
\hline & 478. & $\operatorname{ts} \varepsilon n$ & $\mathrm{~d} z \varepsilon \mathrm{n}$ & $p$ 前 & s 踐 & c 荐 & \\
\hline & 479. & $z \varepsilon n$ & $z \varepsilon n$ & p㳄 & & $c$ 羡 & $(87,117 a)$ \\
\hline & 480. & șen & șદn & $\mathrm{p}$ 鋋 & $\mathrm{s}$ 善 & c 繕 & \\
\hline & 481. & $\mathrm{j} \varepsilon n$ & jen & p延 & s 演 & $c$ 街 & \\
\hline & 482. & $\operatorname{l\varepsilon n}$ & $\operatorname{l\varepsilon n}$ & $\mathrm{p}$ 蓮 & $\mathrm{s}$ 䊗 & c 練 & \\
\hline & 483. & $\dot{\mathbf{r}} \varepsilon \mathrm{n}$ & $\dot{\mathbf{r}} \varepsilon n$ & $\mathrm{p}$ 然 & s 㷬 & & \\
\hline 公 & 484. & gen & ken & $\mathrm{p}$ 髯 & $\mathrm{s}$ 鼠 & $\mathrm{c}$ 見 & \\
\hline & 485. & k'en & k'en & $\mathrm{p}$ & $\mathrm{s}$ 遣 & $\mathrm{c}$ 俔 & \\
\hline & 486. & dzen & ț̣en & $\mathrm{p}$ 穊 & $\mathrm{s}$ 展 & $\mathrm{c}$ 戰 & \\
\hline & 487. & țṣ'en & ț̣s'en & $\mathrm{p}$ 燀 & $\mathrm{s}$ 闡 & c 硟 & $(88,117 a)$ \\
\hline & 488. & ben & pen & $\mathrm{p}$ 櫋 & s 楩 & $\mathrm{c}$ 變 & \\
\hline & 489. & p'en & p'en & $\mathrm{p}$ 篇 & $\mathrm{s}$ 瓶 & c 片 & \\
\hline & 490. & dzen & tsen & $\mathrm{p}$ 箋 & $\mathrm{s}$ 剪 & $\mathrm{c}$ 蔍 & \\
\hline
\end{tabular}

85 For $\overline{\text { read }}$ उV. 


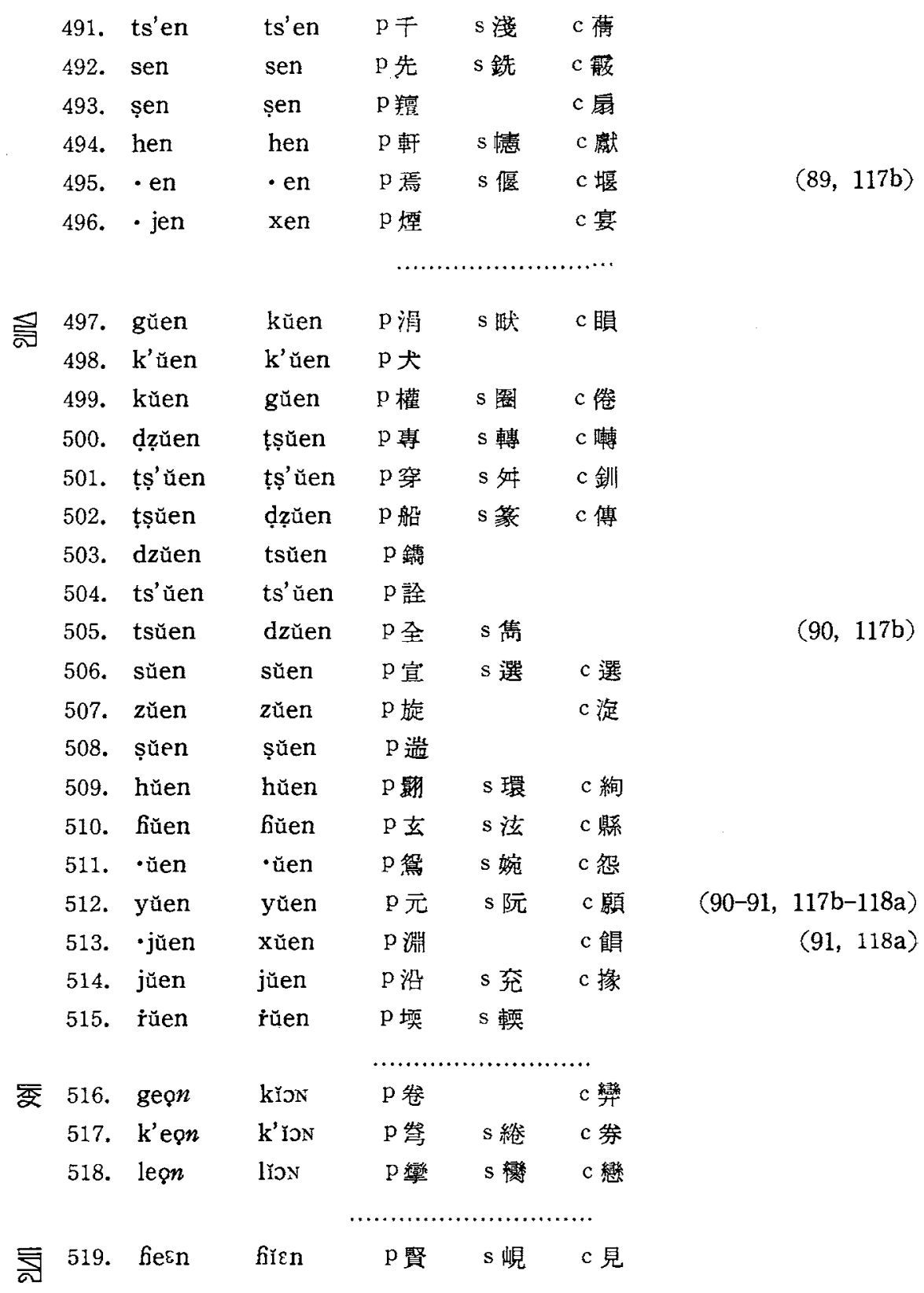




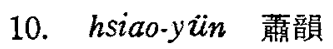

\begin{tabular}{|c|c|c|c|c|c|c|c|}
\hline 质 520 . & $g(a) w$ & kaw & $\mathrm{p}$ 高 & $\mathrm{s}$ 触 & $\mathrm{c}$ 誥 & $\mathrm{j}(\mathrm{k})$ 各 & $(92,118 a)$ \\
\hline 521. & $k^{\prime}(a) w$ & k'aw & & $\mathrm{s}$ 考 & c 館 & $\mathrm{j}(\mathrm{k})$ 恪 & \\
\hline 522. & $g(a) w$ & gaw & $\mathrm{p}$ 敖 & & c 傲 & $j(k)$ 骂 & \\
\hline 523. & $d(a) w$ & taw & $\mathrm{p}$ 刀 & $\mathrm{s}$ 倒 & $\mathrm{c}$ 到 & & \\
\hline 524. & $t^{\prime}(a) w$ & t'aw & $\mathrm{p}$ 坛 & s 討 & & $j(k)$ 託 & \\
\hline 525. & $t(a) w$ & daw & $\mathrm{p}$ 陣 & $\mathrm{s}$ 道 & $\mathrm{c}$ 導 & $\mathrm{j}(\mathrm{k})$ 鐸 & $(92-93, \quad 118 a-b)$ \\
\hline 526. & $n(a) w$ & naw & $\mathrm{p}$ 录 & $\mathrm{s}$ 腦 & $\mathrm{c}$ 墝 & $\mathrm{j}(\mathrm{k})$ 諾 & $(93,118 \mathrm{~b})$ \\
\hline 527. & $d z(a) w$ & țșaw & $\mathrm{p}$ 嘲 & $\mathrm{s} \pi$ & c 罩 & & \\
\hline 528. & $t s^{\prime}(a) w$ & tș'aw & $\mathrm{p}$ 抄 & $\mathrm{s}$ 炒 & $c$ 抄 & & \\
\hline 529. & $\operatorname{tṣ}(a) w$ & dzaw & $\mathrm{p}$ 巢 & & $\mathrm{c}$ 棹 & & \\
\hline 530. & $b(a) w$ & paw & $\mathrm{p}$ 褒 & $\mathrm{s}$ 寶 & $\mathrm{c}$ 報 & $\mathrm{j}(\mathrm{k})$ 愽 & \\
\hline 531. & $p^{\prime}(a) w$ & p'aw & $\mathrm{p}$ 胞 & & $\mathrm{c}$ 䆛 & $\mathrm{j}(\mathrm{k})$ 濼 & \\
\hline 532. & $\mathrm{p}(\mathrm{a}) \mathrm{w}$ & baw & $\mathrm{p}$ 危 & $\mathrm{s}$ 鮑 & $\mathrm{c}$ 鉋 & $\mathrm{j}(\mathrm{k})$ 需 & $(94,118 b)$ \\
\hline 533. & $\mathrm{~m}(\mathrm{a}) \mathrm{w}$ & maw & $p$ 毛 & $\mathrm{s}$ 卯 & $\mathrm{c}$ 帽 & $\mathrm{j}(\mathrm{k})$ 寞 & \\
\hline 534. & fü $(a) w$ & vaw & & & & $j(k)$ 囀 & \\
\hline 535. & $\mathrm{~d} z(a) w$ & tsaw & $\mathrm{p}$ 糟 & $\mathrm{s}$ 早 & $\mathrm{c}$ 篦 & $\mathrm{j}(\mathrm{k})$ 作 & \\
\hline 536. & $t s^{\prime}(a) w^{86}$ & ts'aw & $\mathrm{p}$ 操 & s 草 & $\mathrm{c}$ 操 & $\mathrm{j}(\mathrm{k})$ 錯 & \\
\hline 537. & $\operatorname{ts}(a) w$ & dzaw & $\mathrm{p}$ 曹 & $\mathrm{s}$ 辛 & c 漕 & $\mathrm{j}(\mathrm{k})$ 昨 $(\mathrm{s}$ & $94-95,118 b-119 a)$ \\
\hline 538. & $\mathbf{s}(\mathbf{a}) \mathrm{w}$ & saw & $\mathrm{p}$ 騷 & s 嫂 & $\mathrm{c}$ 喿 & $\mathrm{j}(\mathrm{k})$ 索 & $(95,119 a)$ \\
\hline 539. & ș(a)w & șaw & $\mathrm{p}$ 稍 & & $\mathrm{c}$ 稍 & & \\
\hline 540. & $\mathrm{~h}(\mathbf{a}) \mathrm{w}$ & haw & $\mathrm{p}$ 冏 & s 好 & c 耗 & & \\
\hline 541. & $r(a) w$ & raw & $\mathrm{p}$ 豪 & $\mathrm{s}$ 䊁 & c 號 & $\mathrm{j}(\mathrm{k})$ 涸 & \\
\hline 542. & - (a)w & - aw & $\mathrm{p}$ 鍾 & $\mathrm{s}$ 襖 & $\mathrm{c}$ 奧 & $\mathrm{j}(\mathrm{k})$ 惡 & \\
\hline 543. & $\cdot j(a) w$ & xaw & $\mathrm{p}$ 坳 & $\mathrm{s}$ 拗 & $\mathrm{c}$ 靮 & $\mathrm{j}(\mathrm{k})$ 渥 & $(96,119 a)$ \\
\hline 544. & $j(a) w$ & jaw & $\mathrm{p}$ 鳌 & $\mathrm{s}$ 龁交 & $\mathrm{c}$ 樂 & $\mathrm{j}(\mathrm{k})$ 㠍 & \\
\hline 545. & $\mathrm{I}(\mathrm{a}) \mathrm{w}$ & law & $\mathrm{p}$ 勞 & s 老 & c 嫪 8 & 7 j(k) 落 & \\
\hline
\end{tabular}

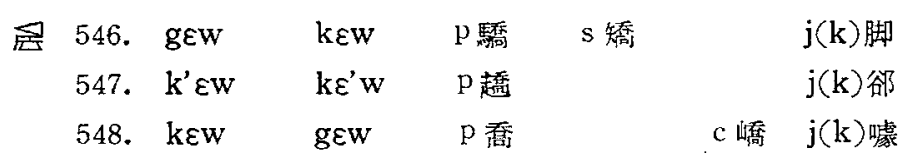

86 For $\overline{5}$ read $\sim$

87 The character 上 (shang-sheng) in the PSPT edition must be corrected to 去 (ch'ü-sheng). 


\begin{tabular}{|c|c|c|c|c|c|c|c|c|}
\hline & 549. & nEw & 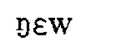 & $\mathrm{p}$ 鴣 & & & $\mathrm{j}(\mathrm{k})$ 虐 & \\
\hline & 550. & $\mathrm{t} \varepsilon w$ & dew & p 迢 & s 宊 & c 薙 & & \\
\hline & 551. & ḍz̨w & ț̨̣ & $\mathrm{p}$ 朝 & s 沼 & c 照 & $\mathrm{j}(\mathbf{k})$ 著 & $(97,119 b)$ \\
\hline & 552. & $t s^{\prime} \varepsilon w$ & țș' $\varepsilon w$ & $\mathrm{p}$ 妿 & & & $\mathbf{j}(\mathbf{k})$ 綽 & \\
\hline & 553. & țṣ $\varepsilon w$ & $\mathrm{~d} z \underline{\ell} \mathrm{w}$ & $p$ 㫤 & s 肇 & c 召 & $\mathrm{j}(\mathbf{k})$ 著 & \\
\hline & 554. & bew & prw & $\mathrm{p}$ 鏗 & s禋 & & & \\
\hline & 555. & pew & bew & $\mathrm{p}$ 骠 & s 摽 & c 驃 & & \\
\hline & 556. & $\mathrm{~m} \varepsilon w$ & $\mathrm{~m} \varepsilon \mathrm{w}$ & $\mathrm{p}$ 苗 & $\mathrm{s}$ 眇 & c 妙 & & \\
\hline & 557. & șદW & ș & $\mathrm{p}$ 燒 & s少 & c 燒 & $\mathrm{j}(\mathrm{k})$ 樂 & \\
\hline & 558. & $z \varepsilon w$ & $z \varepsilon w$ & p 韶 & & c 紹 & $j(k)$ 勺 & \\
\hline & 559. & hew & hew & $\mathrm{p}$ 譻 & & & $\mathrm{j}(\mathrm{k})$ 戱 & \\
\hline & 560. & $\cdot \varepsilon W$ & $\cdot \varepsilon W$ & $\mathrm{p}$ 妖 & s天 & & $j(k)$ 約 & $(98,119 b)$ \\
\hline & 561. & $\mathrm{j} \varepsilon \mathrm{w}$ & $\mathrm{j} \varepsilon \mathrm{w}$ & $\mathrm{p}$ 堯 & $\mathrm{s}$ 鷕 & c 穻 & $\mathrm{j}(\mathrm{k})$ 藥 & \\
\hline & 562. & lew & lew & $\mathrm{p}$ 聊 & s 了 & c 料 & $\mathrm{j}(\mathrm{k})$ 略 & \\
\hline & 563. & $\dot{\mathbf{r}} \varepsilon w$ & $\dot{\mathrm{r}} \varepsilon \mathrm{W}$ & $\mathrm{p}$ 餴 & s 擾 & & $\mathbf{j}(\mathbf{k})$ 若 & \\
\hline 空 & 564. & gew & kew & p 蹺 & s 鲛 & c AL & & \\
\hline & 565. & k'ew & k'ew & $\mathrm{p}$ 跨 & & $\mathrm{c}$ 竅 & & \\
\hline & 566. & kew & gew & $\mathrm{p}$ 䞨 & & & & $(99,120 a)$ \\
\hline & 567. & dew & tew & p貛 & $\mathrm{s}$ 鳥 & $c$ 吊 & & \\
\hline & 568. & t'ew & t'ew & $\mathrm{p}$ 眺 & $\mathrm{s}$ 朓 & c 䊮 & & \\
\hline & 569. & new & new & & s 慧 & & & \\
\hline & 570. & țș'ew & tș'ew & $\mathrm{p}$ 超 & & & $\mathrm{j}(\mathrm{k})$ 婼 & \\
\hline & 571. & pew & bew & $\mathrm{p}$ 漂 & $\mathrm{s}$ 縹 & $c$ 殆门 & & \\
\hline & 572. & dzew & tsew & $\mathrm{p}$ 焦 & $\mathrm{s}$ 勦 & c 醮 & j(k) 爵 & \\
\hline & 573. & ts'ew & ts'ew & $\mathrm{p}$ 鍫 & $\mathrm{s}$ 悄 & $\mathrm{c}$ 陗 & j(k) 鹊 & \\
\hline & 574. & tsew & dzew & $\mathrm{p}$ 樵 & & $\mathrm{c}$ 訜 & $\mathrm{j}(\mathrm{k})$ 嚼 & \\
\hline & 575. & sew & sew & $\mathrm{p}$ 箖 & $\mathrm{s}$ 簿 & $\mathrm{c}$ 笑 & $\mathrm{j}(\mathrm{k})$ 刢 & $(100,120 a)$ \\
\hline & 576. & hew & hew & $\mathrm{p}$ 嘵 & $\mathrm{s}$ 曉 & & & \\
\hline & 577. & fiew & hew & & s 㿟 & & & \\
\hline & 578. & · jew & xew & $\mathrm{p}$ 幺 & s 查 & $c$ 要 & & \\
\hline 胥 & 579. & $g u ̛(a) w$ & kŭaw & & & & $\mathrm{j}(\mathrm{k})$ 郭 & \\
\hline & 580. & $k^{\prime} \breve{u}(a) w$ & $k_{2}^{\prime}$ ŭaw & & & & $\mathrm{j}(\mathrm{k})$ 廊 & \\
\hline
\end{tabular}




\begin{tabular}{|c|c|c|}
\hline 1. & $\mathrm{w}$ & nŭaw \\
\hline 82 . & $\mathrm{d} z \overline{\mathrm{u}}(\mathrm{a}) \mathrm{w}$ & ț̣̦ŭaw \\
\hline 83. & țș'ú(a)w & țș' ŭau \\
\hline & tșŭ(a)w & dzŭaw \\
\hline & $s ̦ \breve{u}(a) w$ & șŭaw \\
\hline & $h \breve{u}(\mathbf{a}) w$ & hŭaw \\
\hline & $\gamma \breve{\mathrm{u}}(\mathrm{a}) \mathrm{w}$ & $\gamma$ ŭaw \\
\hline & $\cdot \breve{\mathrm{u}}(\mathrm{a}) \mathrm{w}$ & - ŭaw \\
\hline & $w$ & lŭaw \\
\hline
\end{tabular}

$\mathrm{j}(\mathrm{k})$ 㨨

$\mathrm{j}(\mathrm{k})$ 捉

$\mathrm{j}(\mathrm{k})$ 遑

$\mathrm{j}(\mathrm{k})$ 浞

$\mathrm{j}(\mathrm{k})$ 䩗

$\mathrm{j}(\mathrm{k})$ 霍

$\mathrm{j}(\mathrm{k})$ 穫

$\mathrm{j}(\mathrm{k})$ 艘

$\mathrm{j}(\mathrm{k})$ 犖:
(101, 120b)

$(102,120 b)$

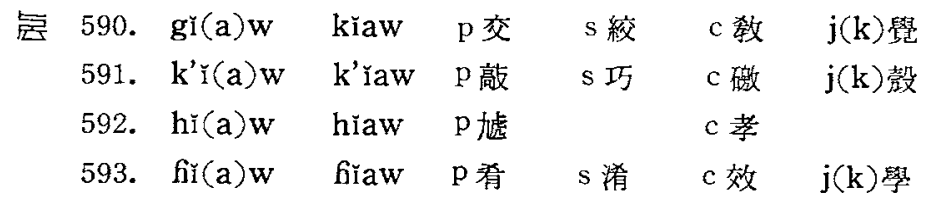

$\mathrm{j}(\mathrm{k})$ 獾

$j(k)$ 䨘

$\mathrm{j}(\mathrm{k})$ 㸌

$\mathrm{j}(\mathrm{k})$ 簿

598. $\mathrm{b}(\mathrm{a}) \cdot 0^{88}$ paw 御寶上用此寶字

11. $y u-y$ ün 尤韻

还 599. giw kiw p鳩 s 九 $\mathrm{c}$ 救

88 The character 璸 normally belongs to No. 530 (shang-sheng), but this spelling was used for this character only when written on Imperial treasure. In Chinese 'Phagspa documents, - in the intervocalic position occurs only in this character. In the Mongolian documents, ' - in intervocalic position served to indicate a hiatus between two adjacent vowels belonging to two separated syllables' (Poppe, The Mongolian Monuments ..., p. 23). The only interpretation of this spelling of $b a \cdot o$ is that people in the Yüan court pronouced paw very clearly to distinguish it from ordinary paw, thus resulting in pao. The Mongolians then denoted this as $p a \cdot o$ in the Mongolian way. 


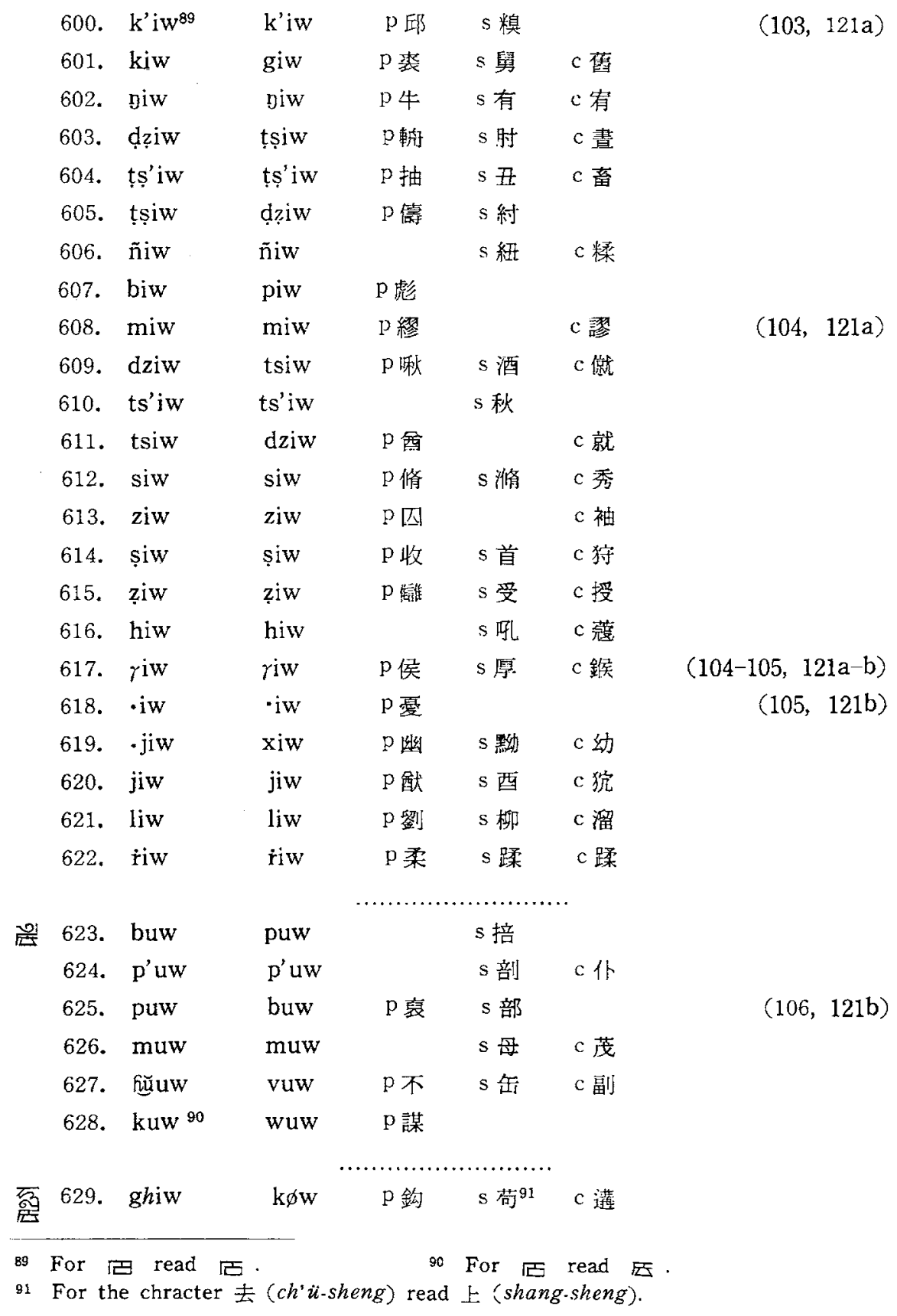




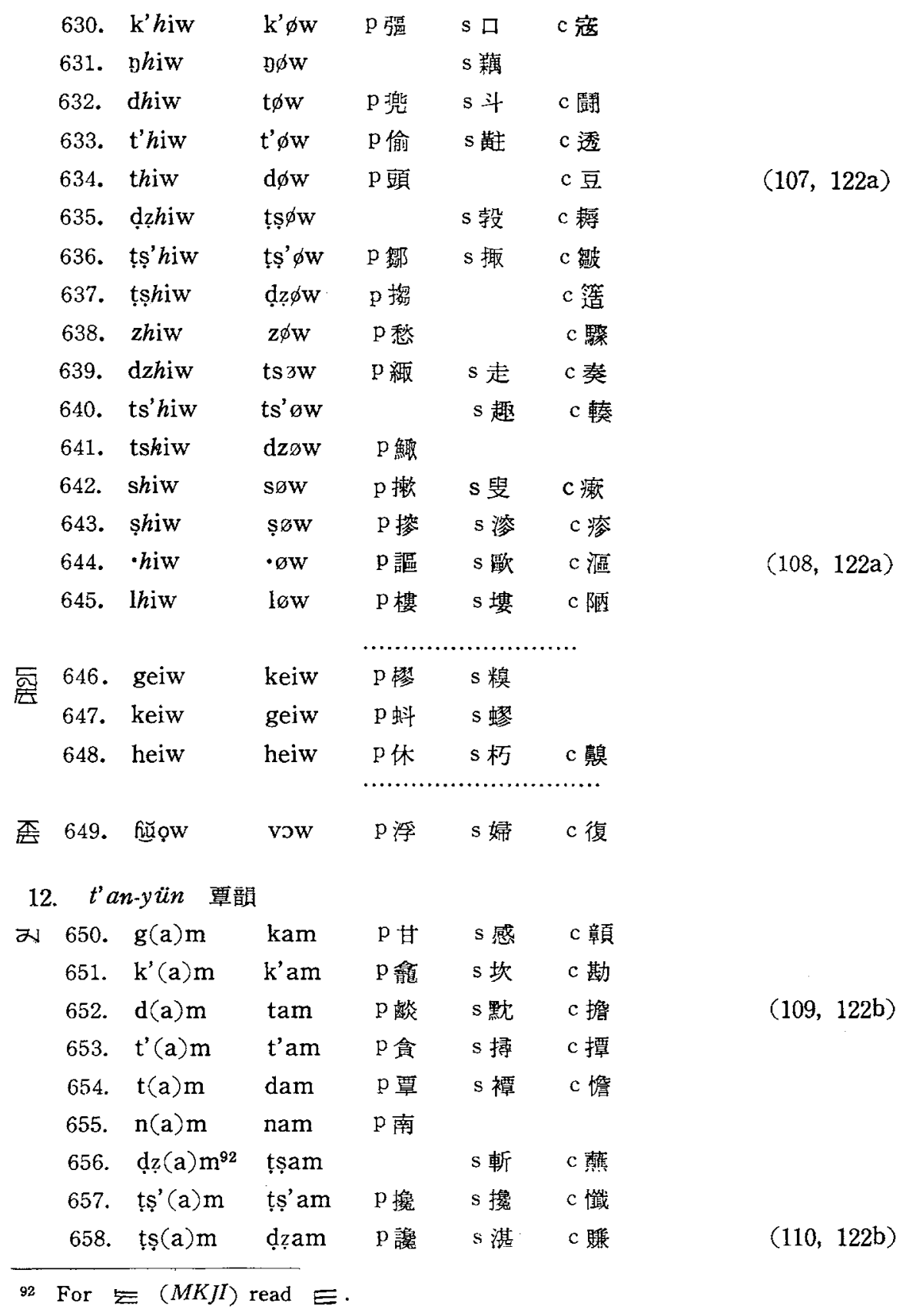




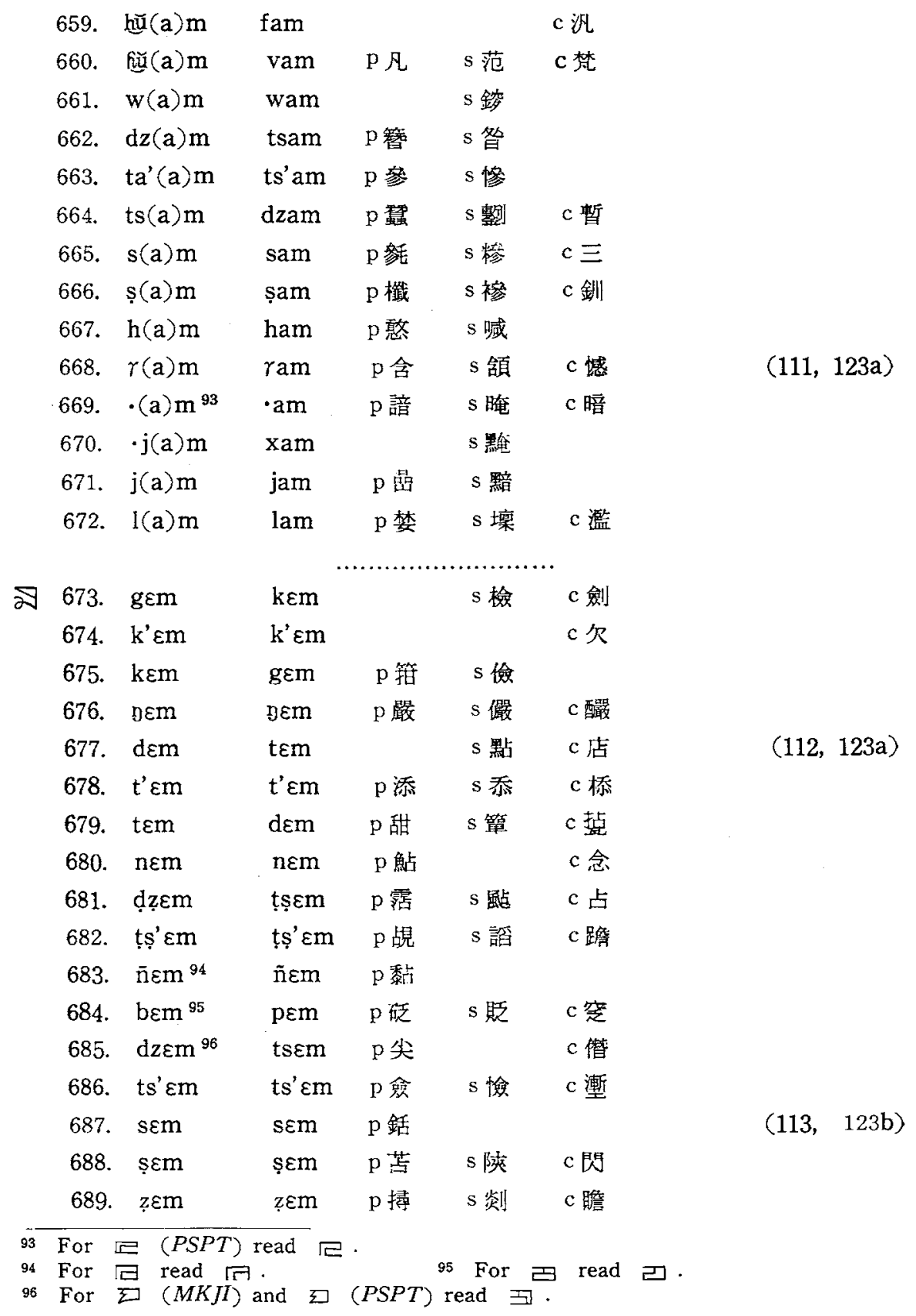




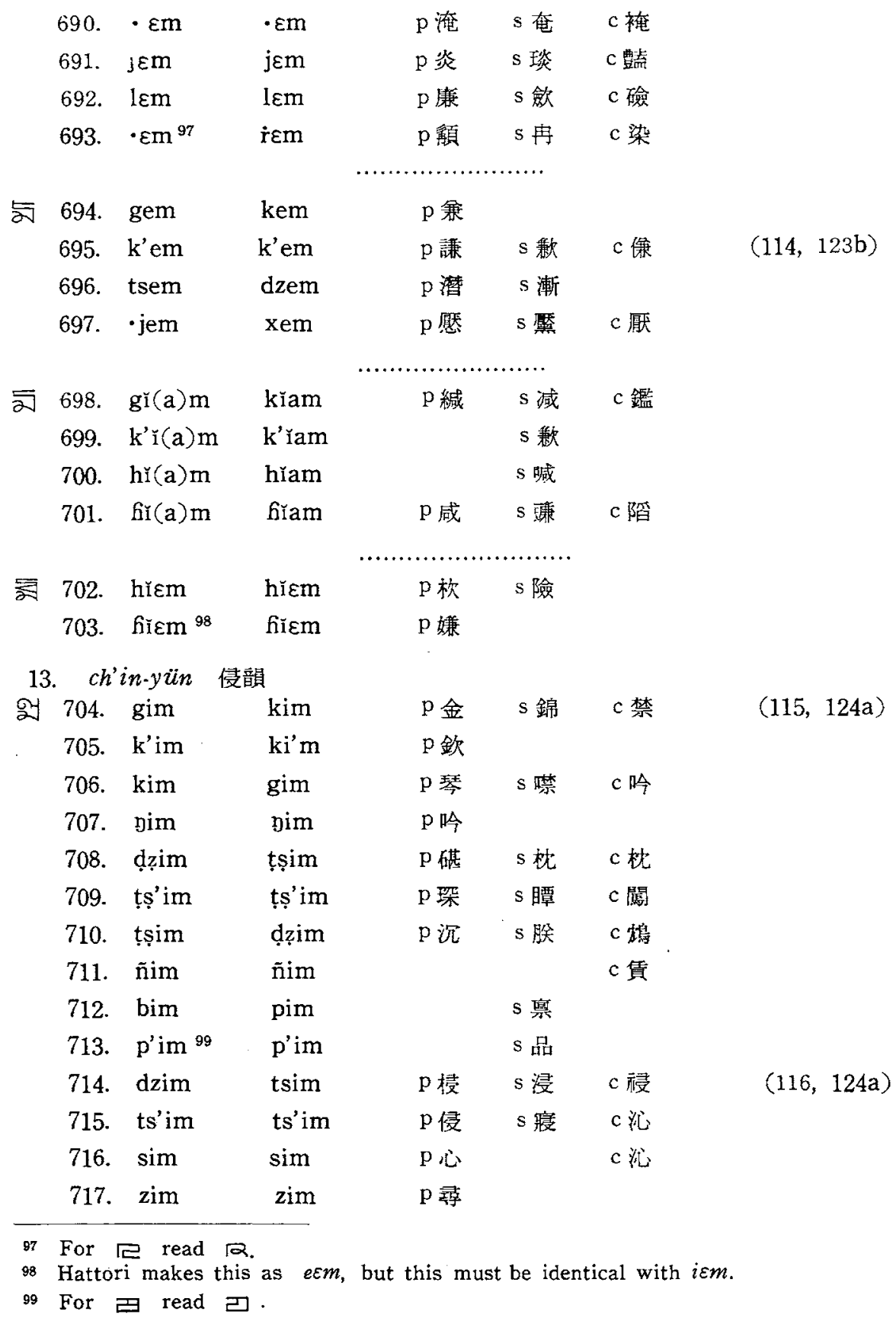


718. șim șim $p$ 哚 $s$ 沈

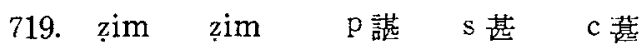

720. $\cdot \mathrm{im} \cdot \mathrm{im} \quad \mathrm{p}$ 番 $\mathrm{s}$ 飲 $\mathrm{c}$ 蔭

721. .jim xim $\mathrm{p}$ 愔

722. jim jim $\mathrm{p}$ 滛

723. $\lim { }^{100} \lim \mathrm{p}$ 林 $\mathrm{s}$ 盧

724. rim rim $\mathrm{p}$ 任 $\mathrm{s}$ 荏 $\mathrm{c}$ 姡

$(117,124 b)$

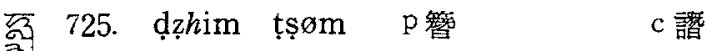

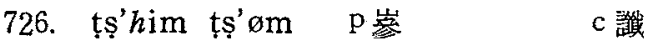

727. ț̣̣him dụøm p 岑

728. șhim șøm $\mathrm{p}$ 森 $\mathrm{c}$ 沜

富 729. hrim hrim p 歆

14. ko-yün 歌韻

\begin{tabular}{|c|c|c|c|c|c|c|}
\hline 730. & go & ko & $\mathrm{p}$ 歌 & $\mathrm{s}$ 愬 & $\mathrm{c}$ 䉪 & $j(t p)$ 葛 \\
\hline 731. & k'o & k'o & $p$ 珂 & $\mathrm{s}$ 可 & $\mathrm{c}$ 坷 & $\mathrm{j}(\mathrm{ktp})$ 渴 \\
\hline 732. & yo & no & $\mathrm{p}$ 㧴 & s 我 & c 餓 & $\mathrm{j}(\mathrm{t})$ 辝 \\
\hline 733. & do & to & $\mathrm{p}$ 多 & S 㲔 & $\mathrm{c}$ 痒 & \\
\hline 734. & $t^{\prime} o$ & t'o & $\mathrm{p}$ 帒 & & $\mathrm{c}$ 拖 & \\
\hline 735. & to & do & $\mathrm{p}$ 駝 & $\mathrm{s}$ 柁 & $\mathrm{c}$ 駄 & \\
\hline 736. & no & no & $\mathrm{p}$ 那 & $\mathrm{s}$ 娜 & c 柰 & \\
\hline 737. & $\mathrm{~d} z o$ & tso & & $\mathrm{s}$ 左 & c 佐 & \\
\hline 738. & ts'o & ts'o & $\mathrm{p}$ 蹉 & $\mathrm{s}$ 差 & & \\
\hline 739. & tso & dzo & $\mathrm{p}$ 酰 & & & \\
\hline 740. & so & so & $\mathrm{p}$ 梁 & & c 些 & \\
\hline 741. & ho ${ }^{101}$ & ho & $\mathrm{p}$ 訶 & $\mathrm{s}$ 㰤 & & $j(t p)$ 喝 \\
\hline 742. & ro & ro & $\mathrm{p}$ 何 & $\mathrm{s}$ 荷 & c 賀 & $\mathrm{j}(\mathrm{t} p)$ 曷 \\
\hline 743. & $\cdot 0$ & $\cdot 0$ & $\mathrm{p}$ 阿 & & & $\mathrm{j}(\mathrm{tp})$ 罯 \\
\hline 744. & 10 & 10 & $\mathrm{p}$ 羅 & $\mathrm{s}$ 攞 & & \\
\hline
\end{tabular}

$(118,124 b)$

$(119,125 a)$

尺 745. gŭo kŭo $\mathrm{p}$ 戈 $\mathrm{s}$ 果 $\mathrm{c}$ 過 $\mathrm{j}(\mathrm{t})$ 括

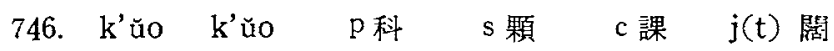

100 For 民⿸丆 read ש. 101 For $\bar{n}$ read $\overline{2}$. 


\begin{tabular}{|c|c|c|c|c|c|c|c|}
\hline 747 & dŭo & tŭo & & s 埵 & & $j(t)$ 掇 & \\
\hline 748. & $t^{\prime}$ ŭo & $t^{\prime}$ ŭo & $\mathrm{p}$ 詑 & s 安 & c 唾 & $\mathrm{j}(\mathrm{t})$ 侻 & $(120,125 a)$ \\
\hline 749. & tŭo & dǔo & & $\mathrm{s}$ 椥 & $\mathrm{c}$ 墮 & $\mathrm{j}(\mathrm{t})$ 奪 & \\
\hline 50. & nŭo & nŭo & $p$ 捼 & & c 湎 & & \\
\hline 751. & bŭo & pŭo & p 波 & s 跂 & c 播 & $\mathrm{j}(\mathrm{t})$ 莣 & \\
\hline 752. & p'ŭo & p'ǔo & $\mathrm{p}$ 頗 & s區 & $\mathrm{c}$ 破 & $j(t)$ 鏺 & \\
\hline 753. & pŭo & bǔo & p婆 & & & $\mathrm{j}(\mathbf{t})$ 践 & \\
\hline 754. & mŭo & mŭo & $\mathrm{p}$ 摩 & $\mathrm{s}$ 麼 & $\mathrm{c}$ 穈 & $j(t)$ 末 & \\
\hline 755. & dzŭo & tsŭo & & & $\mathrm{c}$ 挫 & $\mathrm{j}(\mathrm{t})$ 撮 & \\
\hline 756. & ts' ŭo & $t s^{\prime}$ ŭo & & $\mathrm{s}$ 脞 & $\mathrm{c}$ 轨 & $\mathrm{j}(\mathrm{t})$ 撮 & \\
\hline 757. & tsŭo & $\mathrm{dzŭo}$ & $\mathrm{p}$ 榘 & $\mathrm{s}$ 坐 & $\mathrm{c}$ 坐 & & \\
\hline 758. & sŭo & sŭo & $\mathrm{p}$ 莎 & $\mathrm{s}$ 鏆 & & & $(121,125 b)$ \\
\hline 759. & hŭo ${ }^{102}$ & hŭo & & s 火 & c 貨 & $\mathrm{j}(\mathrm{t})$ 豁 & \\
\hline 760. & $\gamma$ ŭo & $\gamma$ ŭo & $\mathrm{p}$ 和 & s 禍 & $c$ 和 & $\mathrm{j}(\mathrm{t})$ 佸 & \\
\hline 761. & • ŭo & • йo & $\mathrm{p}$ 倭 & & c 涴 & $\mathrm{j}(\mathrm{t})$ 斡 & \\
\hline 762. & lŭo & lŭo & $\mathrm{p}$ 騾 & $\mathrm{s}$ 裸 & c 邏 & $\mathrm{j}(\mathrm{t})$ 渭 & \\
\hline
\end{tabular}

763. $\circ$ o p 伡 c 卧

15. ma-yün 麻韻

764. ge ke

765. k'e k'e

766. de te

767. t'e t'e

768. ne ne

769. ḑ̣e țșe

770. țș'e țș'

771. be pe

772. p'e p'e

773. me me

774. dze ${ }^{103}$ ts

775. ts'e ts'e

776. se $\mathrm{se}^{104}$ se

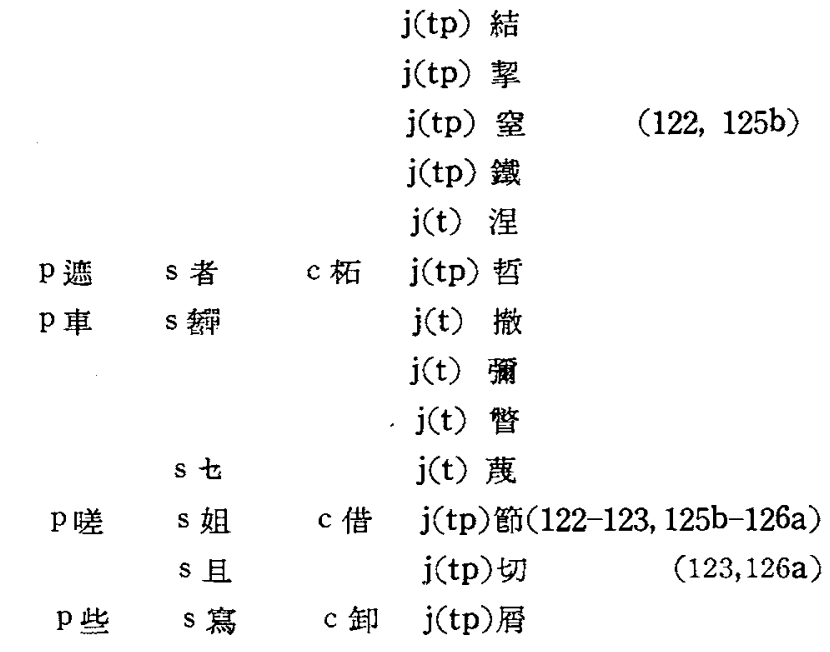

$j(t p)$ 結

$j(t p)$ 絜

公

$j(t)$

$\mathrm{j}(\mathrm{t})$ 暂

(t) 形

$j(t)$ 政

$\mathrm{j}(\mathrm{tp})$ 篩 $(122-123,125 \mathrm{~b}-126 \mathrm{a})$

$j(t p)$ 切

104 For 즌 read 짇. 


\begin{tabular}{|c|c|c|c|c|c|c|c|c|}
\hline & 777. & $s \mathrm{e}^{105}$ & șe & $\mathrm{p}$ 奢 & $\mathrm{s}$ 捨 & $\mathrm{c}$ 舍 & $\mathrm{j}(\mathrm{tp})$ 攝 & \\
\hline & 778. & he & he & & & & $\mathrm{j}(\mathrm{p})$ 脅 & \\
\hline & 779. & fe & fe & & & & $j(t p)$ 纈 & \\
\hline & 780. & $\cdot \mathrm{e}^{106}$ & $\cdot \mathrm{e}$ & & & & $j(t p)$ 謁 & \\
\hline & 781. & $\cdot \mathrm{je}$ & $\mathrm{xe}$ & & & & $j(t)$ 鈤 & \\
\hline & 782. & $\mathrm{je}$ & je & & & & $\mathrm{j}(\mathrm{t})$ 絜 & \\
\hline & 783. & le & le & & & & $\mathrm{j}(\mathrm{tp})$ 列 & $(124,126 a)$ \\
\hline & 784. & $\dot{\mathrm{re}}$ & re & & $\mathrm{s}$ 惹 & & $j(t)$ 熱 & \\
\hline 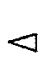 & 785. & $\mathrm{~g}_{\breve{u}}(\mathbf{a})^{107}$ & kŭa & $\mathrm{p}$ 瓜 & s 寡 & & $\mathrm{j}(\mathrm{t})$ 刮 & \\
\hline & 786. & $k^{\prime} \breve{u}(a)$ & $k^{\prime}$ ŭa & $\mathrm{p}$ 誇 & $\mathrm{s}$ 髅 & c 跨 & & \\
\hline & 787. & $\tilde{n} u \mathbf{u}(\mathbf{a})$ & ñŭa & & & & $j(t)$ 擖 & \\
\hline & 788. & $\mathrm{~d} z \underline{\mathrm{u}}(\mathrm{a})$ & ț̣̆ua & $\mathrm{p}$ 檛 & & & $j(t)$ 茁 & \\
\hline & 789. & șŭ(a) & șŭa & & $\mathrm{s}$ 䔖 & & $\mathrm{j}(\mathrm{t})$ 刷 & \\
\hline & 790. & hŭ $(a)$ & hŭa & $\mathrm{p}$ 華 & & c 化 & & \\
\hline & 791. & $\gamma \check{u}(a)$ & $\gamma$ ǔa & $\mathrm{p}$ 華 & s 踝 & $\mathrm{c}$ 匑 & $j(t)$ 滑 & \\
\hline & 792. & $\cdot$ ú $(a)$ & • & $\mathrm{p}$ 窊 & & & & $(125,126 \mathrm{~b})$ \\
\hline & 793. & $y \breve{u}(a)^{108}$ & yŭa & & s 瓦 & & $\mathrm{j}(\mathrm{t})$ 肘 & \\
\hline$\in$ & 794 & $\mathrm{~g} \check{I}(\mathrm{a})$ & kra & $\mathrm{p}$ 繁 & $\mathrm{s}$ 榎 & c 駕 & $\mathrm{j}(\mathrm{tp})$ 昆 & \\
\hline & 795 & $k^{\prime} \mathbf{i}(a)$ & $k^{\prime} \mathfrak{i} a$ & & s 骼 & c 髂 & $\mathrm{j}(\mathrm{tp})$ 籍 & \\
\hline & 796. & $h \breve{i}(a)$ & h'ìa & $\mathrm{p}$ 鰕 & & $\mathrm{c}$ 㖫赤 & $\mathrm{j}(\mathrm{tp})$ 瞎 & \\
\hline & 797. & fir $(a)$ & Gra & $\mathrm{p}$ 澱 & s 下 & $\mathrm{c}$ 睱 & $j(t p)$ 黠 & \\
\hline \multirow[t]{7}{*}{$\leqq$} & 798. & gŭe & kŭe & & & & $\mathrm{j}(\mathrm{t})$ 玦 & \\
\hline & 799. & k'ŭe & $k$ 'ŭe & & & & $\mathrm{j}(\mathbf{t})$ 閣 & $(126,126 b)$ \\
\hline & & d’̣ŭe 109 & ț̣̦ŭe & & & & $j(t)$ 輟 & \\
\hline & 801. & tș̣̆u & țş'ǔe & & & & $j(t)$ 政 & \\
\hline & & dzŭe & tsŭe & & & & $j(t)$ 䔄 & \\
\hline & & tsŭe & dzŭe & & & & $\mathrm{j}(\mathbf{t})$ 絕 & \\
\hline & 804. & sŭe & sŭe & & & & $j(t)$ 雪 & \\
\hline 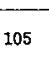 & & 2 read & & & $106 \mathrm{Fo}$ & or 3 & read 窝. & \\
\hline 10 & & PSPT edition & ks the & & -pa spe & elling $o$ & of this sound. & \\
\hline
\end{tabular}




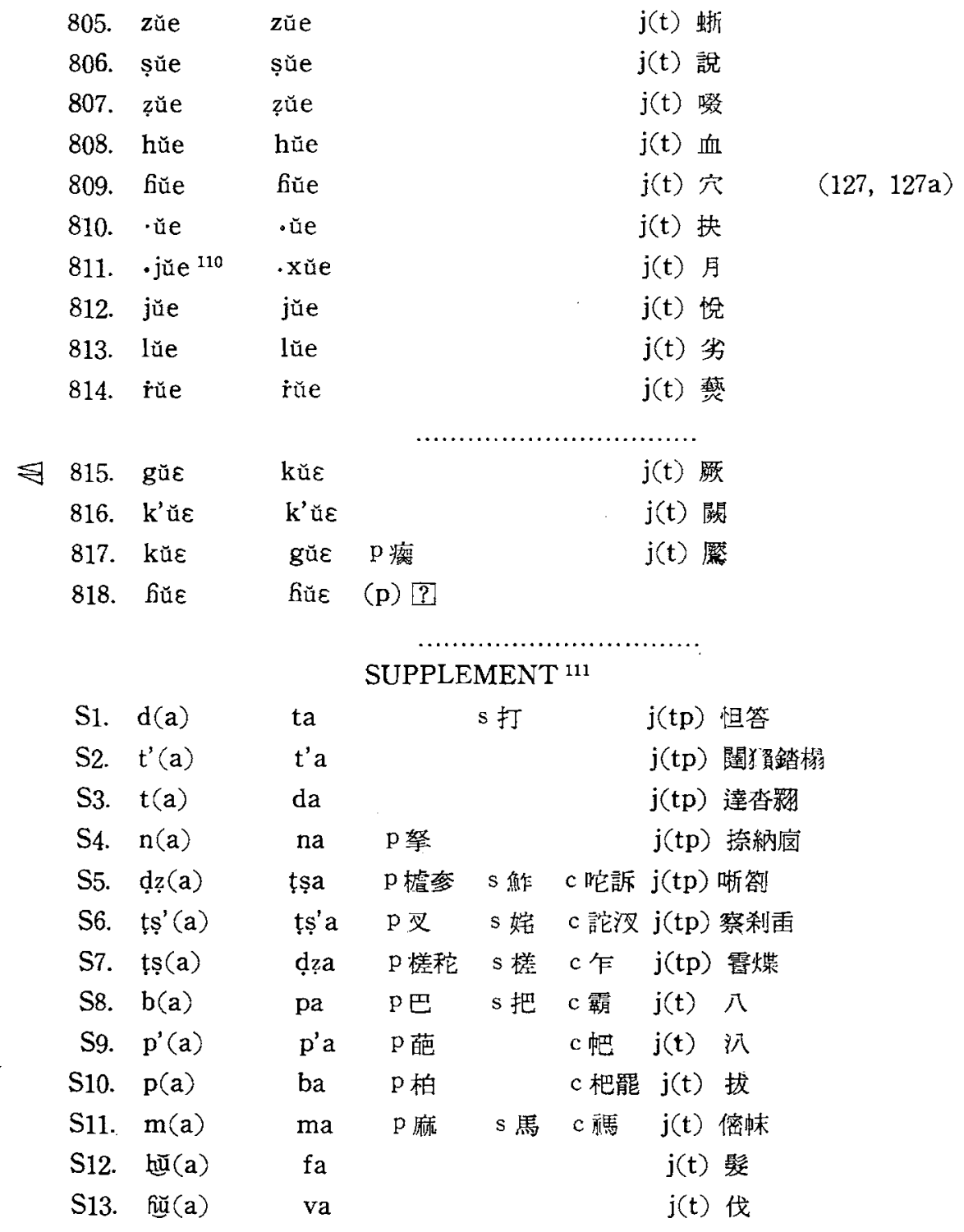

110 For $\square$ read $\pi$.

111 The manuscript of the MKTY held in the British Museum lacks the last two final groups $-a$ and $-\varepsilon$. A supplement was written by Cheng. Tsai-fa with reference to the KYC (MKTY ken ken Pa-ssu-pa-tzu yu-kuan te yün-shu, pp. 102-3). I will append his supplement in full for the convenience of readers. 


\begin{tabular}{|c|c|c|c|c|c|c|}
\hline S14. & $w(a)$ & wa & & & & $j(t)$ 韈 \\
\hline S15. & $\mathrm{dz}(\mathrm{a})$ & tsa & & & & $\mathrm{j}(\mathrm{tp})$ 拶而挾眨 \\
\hline S16. & $\mathrm{ts}^{\prime}(\mathrm{a})$ & ts'a & & & & $j(t)$ 攃 \\
\hline S17. & $\operatorname{ts}(a)$ & $\mathrm{d} z \mathrm{a}$ & & & & $\mathrm{j}(\mathrm{tp})$ 截襍 \\
\hline S18. & $s(a)$ & sa & & & & $j(t p)$ 筅趿 \\
\hline S19. & $s ̦(a)$ & șa & $\mathrm{p}$ 沙 & s 溜 & $\mathrm{c}$ 嗄 & $j(t p)$ 殺軟 \\
\hline S20. & $h(a)$ & ha & & $\mathrm{s}$ 閣 & & \\
\hline S21. & $\cdot j(a)$ & $\mathrm{xa}$ & $\mathrm{p}$ 鴉 & $\mathrm{s}$ 眍 & c 亞 & $\mathrm{j}(\mathrm{t} p)$ 㜞押 \\
\hline S22. & $j(a)$ & ja & p & $\mathrm{s}$ 雅 & $\mathrm{c}$ 訝 & \\
\hline S23. & $1(a)^{112}$ & la & & & & $\mathrm{j}(\mathrm{tp})$ 剌拉朎 \\
\hline S24. & $\mathrm{g} \varepsilon$ & $\mathrm{k} \varepsilon$ & $\mathrm{p}$ 逝 & & & $\mathrm{j}(\mathrm{t} p)$ 訐规揭子 \\
\hline \$25. & $\mathrm{k}^{\prime} \varepsilon$ & $\mathrm{k}^{\prime} \varepsilon$ & p 呿 & & & $j(t p)$ 堨筮 \\
\hline S26. & $\mathrm{k} \varepsilon$ & $g \varepsilon$ & $\mathrm{p}$ 伽 & & & $\mathrm{j}(\mathrm{tp})$ 竭跲傑 . \\
\hline S27. & $\eta \varepsilon$ & $\mathrm{\eta} \varepsilon$ & & & & 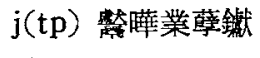 \\
\hline S28. & $\mathrm{t} \varepsilon$ & $\mathrm{d} \varepsilon$ & & & & $\mathrm{j}(\mathrm{t} p)$ 牌姪 \\
\hline S29. & $\mathrm{t} \operatorname{s} \varepsilon$ & $\mathrm{d} z \underline{\varepsilon} \varepsilon$ & $\mathrm{p}$ 蛇 & & $\mathrm{c}$ 射 & $j(t p)$ 䐑轍舌 \\
\hline S30. & $\mathrm{p} \varepsilon$ & $\mathrm{b} \varepsilon$ & & & & $\mathrm{j}(\mathrm{t})$ 獘別 \\
\hline S31. & ts $\varepsilon$ & $\mathrm{d} z \varepsilon$ & & & c 藉 & \\
\hline S32. & $z \varepsilon$ & $z \varepsilon$ & $\mathrm{p}$ 邪 & s 灺 & $\mathrm{c}$ 謝 & $j(p)$ 捷 \\
\hline S33. & $z \varepsilon$ & $z \varepsilon$ & & $\mathrm{s}$ 閭 & $\mathrm{c}$ 礼 & $j(t p)$ 涉折 \\
\hline S34. & $h \varepsilon$ & $\mathrm{h} \varepsilon$ & & & & $j(t)$ 歇 \\
\hline S35. & $\mathrm{j} \varepsilon$ & $\mathrm{j} \varepsilon$ & & s 野 & $\mathrm{c}$ 夜 & $j(t p)$ 葉抴 \\
\hline
\end{tabular}

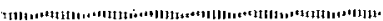

112 For $ᄅ$ (ibid., p. 103) read 


\section{APPENDIX \\ 'PHAGS-PA MATERIALS}

Many 'Phags-pa materials are now available for research in the Chinese, Mongolian, and Tibetan languages. The following list of 'Phags-pa materials is classified into these three languages and is further divided according to provenance, e.g. inscriptions, seals, coins.

Each item is described as follows: title, (1) date, (2) size, (3) place of discovery, (4) present location and (5) reproductions (* decipherments).

Much 'Phags-pa material must be either unknown or inaccessible, and the author welcomes any further information on this subject.

\section{(A) 'PHAGS-PA MATERIALS IN CHINESE}

I. Inscriptions

1. Edict of the Shen-yü-miao Shrine at Lung-men 龍門神禹廟聖旨碑 (1) 1275 , (2) $1.24 \mathrm{~m} . \times 0.73 \mathrm{~m}$., (3) Shensi, Han-ch'eng, (4) Peking University, (5) E. Chavannes, 'Inscriptions et pièces de chancellerie chinoises de l'époque mongole', TP, IX (1908), pp. 373-6, plate 18 ; PSPT, p. 32, plate 4.

2. Edict of the Ch'ung-yang Wan-shou-kung Shrine at Ching-chao-lu 京兆路 重陽萬苝宮聖旨碑

(1) 1269 , (2) $2.07 \mathrm{~m} . \times 1.67 \mathrm{~m}$., (3) Shensi, Chou-chih, (4) Peking University, (5) PSPT, pp. 32-3, plate 5 .

3. Edict of Grant to Pei-yüeh 加封北計聖旨碑

(1) 1291, (2) $1.29 \mathrm{~m} . \times 0.58 \mathrm{~m}$. , (3) Hopei, Ch'ü-yang, (4) Peking University, (5) PSPT, p. 33, plate 6.

4. Edict of the School of the Confucian Shrine 孔子笄學聖旨碑 (1) 1294, (2) $1.34 \mathrm{~m} . \times 0.86 \mathrm{~m}$., (4) Peking University, (5) PSPT, p. 33, plate 7 .

5. Ditto

(1) 1294 , (2) $2.89 \mathrm{~m} . \times 1.14 \mathrm{~m}$., (4) Peking University, (5) PSPT, p. 33, plate 8.

6. Proclamation of Posthumous Grant to Confucius 加封孔子制 
(1) $130 \bar{\tau}$, (2) $2.18 \mathrm{~m} \times 0.76 \mathrm{~m}$, (3) Honan, Yüan-wu, (4) Peking University, (5) PSPT, p. 34, plate 9.

7. Ditto

(1) 1307 , (2) $2.10 \mathrm{~m} \times 0.81 \mathrm{~m}$., (3) Shantung, Ch'ü-fu, (4) Peking University, (5) Chavannes, op.cit., pp. 313-4, plate 1; PSPT, p. 34, plate 10; Kadokawa Shoten (ed.), Sekai Bunkashi Taikei, vol. XVII (Tokyo, 1959), p. 148.

8. Ditto

(1) 1307 , (2) $1.21 \mathrm{~m} . \times 0.61 \mathrm{~m} .$, (3) Hopei, Ting-hsien, (4) Peking University, (5) PSPT, p. 34, plate 11.

9. Proclamation of Special Posthumous Award to Cheng 特贈鄭制宜制誥

(1) 1308 , (2) $1.27 \mathrm{~m} . \times 0.66 \mathrm{~m}$., (3) Shansi, Yang-ch'eng, (4) Peking University, (5) PSPT, p. 34, plate 12 .

10. Ditto 特贈鄭鼎制語

(1) 1312 , (2) $1.42 \mathrm{~m} . \times 0.76 \mathrm{~m}$., (3) Shansi, Yang-ch'eng, (4) Peking University, (5) PSPT, p. 34, plate 13.

11. Edict of the Ta-ch'ung-yang Wan-shou-kung Shrine at Feng-t'ien-lu 奉天路大重陽萬壽宮聖旨碑

(1) 1313 , (2) $2.36 \mathrm{~m} . \times 1.14 \mathrm{~m}$., (3) Shensi, Chou-chih, (4) Peking University, (5) PSPT, pp, 34-5, plate 14.

12. Proclamation of Posthumous Grant to Mencius' Parents 加封孟子父母制 (1) 1316 , (2) $2.64 \mathrm{~m} . \times 0.86 \mathrm{~m}$., (3) Shantung, Tsou-hsien, (4) Peking University, (5) R. Bonaparte, Documents de l'époque des XIIIe et XIVe siècles..., plate XIII, 1 ; Chavannes, op.cit., pp. 342-5, plate $10 ; P S P T$, p. 35. plate 15 .

13. Proclamation of Posthumous Grant to Mencius 加封孟子鄵國亞聖公制 (1) 1331 , (2) $2.48 \mathrm{~m} . \times 0.91 \mathrm{~m}$., (3) Shantung, Tsou-hsien, (4) Peking University, (5) Bonaparte, ibid., plate XIII, 2 ; Chavannes, ibid, pp. 345-7, plate 11 ; PSPT, p. 35, plate 16.

14. Proclamation of Posthumous Grant to Yen-kuo Fu-sheng-kung and his Wife 加封㝇國復聖公制, 追封衰國夫人制

(1) 1331 , (2) $2.31 \mathrm{~m} . \times 0.96 \mathrm{~m}$., (3) Shantung, Ch'ü-fu, (4) Peking University, (5) Chavannes, ibid., pp.329-30, 340-2, plate 5 ; PSPT, p. 35 , plate 17. 
15. Proclamation of Posthumous Grant to Yen-tzu's Parents 加封顏子父母制 (1) 1334 , (2) $1.82 \mathrm{~m} . \times 0.73 \mathrm{~m}$. ., (3) Shantung, Ch'ü.fu, (4) Peking University, (5) Chavannes, ibid., pp. $338-40$, plate $9 ; P S P T$, p. 35 , plate 18.

16. Edict of the Ta-ch'ung-yang Wan-shou-kung Shrine at Feng-t'ien-lu 奉天路大重陽萬㕑宮聖旨碑
(1) 1358 ,
(2) $2.13 \mathrm{~m} . \times 0.99 \mathrm{~m}$. ,
(3) Shensi, Chou-chih,
(4) Peking Uni- versity, (5) PSPT, p. 35, plate 19.

17. Ditto

(1) $13 \hat{3} 3$, (2) $1.70 \mathrm{~m} . \times 0.85 \mathrm{~m}$., (3) Shensi, Chou-chih, (4) Peking University。 (5) $P S P T$, pp. 35-6, plate 20 .

18. Record of the Reconstruction of the Ch'ung-ch'ing-yüan 重修崇慶院記 (1) 1289 , (2) $2.74 \mathrm{~m} . \times 0.94 \mathrm{~m}$, (3) Shantung, Tzu.yang, (4) Peking University, (5) *PSPT, p. 36, plate 21 .

19. Record of the Confucian School at Chung-shan-fu 中山府儒學記 (1) 1294 , (2) $1.44 \mathrm{~m} . \times 0.68 \mathrm{~m}$., (3) Hopei, Ting-hsien, (4) Peking University, (5) *PSPT, p. 36, plate 22 [two words are illegible].

20. Dedicatory Stele to General Liu I 武略將軍遼州知州劉義种道碑 (1) 1300 , (2) $1.34 \mathrm{~m} . \times 0.71 \mathrm{~m}$. , (3) Shansi, Liao-chou, (4) Peking University, (5) $P S P T$, p. 36, plate 23.

21. Proclamation of Posthumous Grant to Confucius 加封孔子制

(1) 1307 , (2) $1.37 \mathrm{~m} . \times 0.63 \mathrm{~m}$., (3) Kiangsu, Wu-hsi, (4) Peking University, (5) $P S P T$, p. 36 , plate 24 .

22. Stele of Ling-chi Chao-yu Hsien-sheng-vvang 霝濟炤佑顯聖王碑 (1) 1350 , (2) $1.65 \mathrm{~m} . \times 0.71 \mathrm{~m}$., (3) Honan, Meng-hsien, (4) Peking University, (5) PSPT, p. 36, plate 25.

23. Stele of Ancestors of the Chang family 張氏先營碑 (1) 1335 , (2) $3.83 \mathrm{~m} . \times 1.39 \mathrm{~m}$., (5) Inner Mongolia, Ch'ih-feng, (4) Peking University, (5)* F.W. Cleaves, 'The Sino-Mongolian inscription of 1335 in memory of Chang Ying-jui ', HJAS, XIII (1950), plates XVII, XVIII, XXIV, XXX ; PSPT, pp. 36-7, plate 26.

24. Edict of the Tung.p'ing.hsüeh School 東平學聖旨碑 (1) 1294 , (2) $2.23 \mathrm{~m} . \times 0.87 \mathrm{~m}$., (3) Shantung, Tung-p'ing, (4) Peking University, (5) PSPT, p. 37, plate 27. 
25. Edict of the School of the Confucian Shrine 孔子廟學聖旨碑

(1) 1294, (2) $1.90 \mathrm{~m} . \times 1.06$., (3) Kiangsu, Sung-chiang, (4) Peking University, (5) G. Pauthier, 'De l'alphabet de Pa'-sse-pa, ...', $J A, \mathrm{~V}$, 19 (1862), plate facing p. 5 ; PSPT, p. 37, plate 28.

26. Edict of Grant to Tung-an-wang 增封東安王詔書碑

(1) 1298 , (2) $2.76 \mathrm{~m} . \times 0.97 \mathrm{~m}$., (3) Shantung, Lin-ch'ü, (4) Peking University, (5) $P S P T$, p. 37, plate 29.

27. Edict of Exemption from Labour Service of "hsiu-ts'ai" in Chiang. huai 江淮㠰秀才雜泛差役詔書碑

(1) 1288, (5) Bonaparte, op. cit., plate XII, 2 ; PSPT, plate 30.

28. Stele of a Christian (1)

(1) 1311, (2) $0.45 \mathrm{~m} . \times 0.30 \mathrm{~m}$., (3) Fukien, Chuanchow, (5)* Wu Wen-

liang, Ch'üan-chou Tsung-chiao Shih-k'o, p. 33, plate 85 ; Kadokawa Shoten, op.cit., p. 159.

29. Ditto (2)

(1) 1324, (2) $0.34 \mathrm{~m} . \times 0.31 \mathrm{~m}$. (3) Fukien, Chuanchow, (5)* Wu Wenliang, ibid., pp. $33-4$, plate 86 (rubbing reproduction on p. 83 ).

30. Ditto (3)

(2) $0.42 \mathrm{~m} . \times 0.28 \mathrm{~m}$., (3) Fukien, Chuanchow, (5)*Wu Wen-liang, ibid.,

p. 34 , plate 87 .

II. Seals

31. T'ai-wei chih yin 太尉之印

(1) 1377，(5)*Hsi-ch'ing hsü-chien 西清續鑑(甲編)；PSPT， p. 19，fig. 1 .

32. Lung-chen-wei pai.hu chih yin 隆鎮衛百户之印

(5) * Tung-pei ku-yin kou-ch'en東北古印鈎沈；PSPT, p. 20. fig. 20.

33. Meng-ku-chün pai-hu yin 蒙古軍百F印

(1) 1295, (2) $6.5 \mathrm{~cm}^{2}$, (5) *W. Simon, 'A $h$ Phags-pa seal of 1295 ', $A M$, n. s. VI (1958), pp. 203-5, plates I, II.

34. Huai-ning-wang yin 懐案王印

(1) 1305 ?, (5) P. Pelliot, 'Un rescrit mongol en écriture 《'phags-pa》', TPS, II, p. 622 [This seal is stamped on this edict-fig. 1]; * E. Haarh, 'L'écriture 'phags-pa vraiment carrée des sceaux chinois des Yüan', $A O$, XXIV, 1-2 (1959), pp. 60, 62 (fig. 1).

35. Ta-Yüan ti-shih t'ung-ling chu-kuo seng-ni chung-hsing Shih-chiao chih 
yin 大元帝師統領諸国僧尼中興釋敎之印

(1) 1295 (5) Seal stamped on the Źa-lu documents. See. TPS, II, pp. 670-754, figs. 124-131; *Haarh, ibid., p. 60, fig. 2. [Haarh mistakenly deciphered this as T'ai-Yüan Ti-shih Jung-ling Chüeh-kuei Sheng-shu Chung-ch'ing Shih-chia-k'0-chih yin 大元帝師冗令是圭聖署中卿釋迦科旨印]

36. Chung-shu-li-pi [read - pu] chih yin 中書䀅部之印

(1) 1306, (5) Seal stamped on the Proclamation of 1306. See Chavannes, op. cit., plate 2 ; Poppe, The Mongolian Monuments in the hP'ags-pa Script, plate VI; *Haarh, ibid., p. 60, fig. 3. [Haarh mistakenly deciphered this as Chung-shu-ling pi-chih-yin 中書令斑旨印.]

37. Chung-shu-sheng yin 中害省印

(1) 1307, (5) Seal stamped on the Proclamation of 1307. See Chavannes, ibid., plate 3 ; Cheng Tsai-fa, 'Pa-ssu-pa-tzu piao-chu...', plate 6.

38. Ta-ssu-t'u yin 大司徒印

(5) Seal stamped on the painting Li Po yin-hsing ' 'u by Liang K'ai ; W. Willettes, Chinese Art, vol. II (Baltimore, 1958), plate 49 ; ${ }^{*}$ Haarh, ibid., p. 60 , fig. 5 [Haarh mistakenly deciphered this seal as $T^{\prime}$ ai-shihtu yin 太侍買印.] ; * S. Hasumi, 'Liang K'ai hitsu Li Po yin-hsing t'u no Pasupamoji “'Ta-ssu-t'u yin” to Anigo ni tsuite', $T H G, 35$ (1968),p. 91. As to re-examination of Haarh's readings concerning items 35,36 , and 38, see M. Nakano, 'Three 'Phags-pa Chinese Seal Inscriptions', $A M$, vol. XVI, part 1 (1971) [in prees].

39. Tsung-pa chih yin 總把之印

(3) Chekiang, Yung-chia, (5) * Ts'ai Mei-piao, 'Yung-chia fa-hsien Yüantai Meng-wen-yin k'ao-shih', WWTK, 89 (1958), pp. 42-3.

40. Hsiao-chung-i Ch'ien-hu so-t'i ya-yin 驍忠義于戶所提押印

(2) $5.8 \mathrm{~cm}^{2}$, (3) Inner Mongolia, O-t'o-k'e ch'i, (5)* $W W, 182(1965)$, p. 62.

41. Seal (illegible) stamped on the Edict of Annanda

(1) 1283, (5) Bonaparte, op. cit., plate XII, 1; Poppe, op.cit., plate V. III. P'ai-tzu

42. Kai-kuan ching-lü 該官族問 (?)

(5) Lo Chen-yü, Li-tai Fu-p'ai T'u-lu 歷代符牌圖錄, vol, 2 ; W. Yanai, Mōkoshi Kenkyü, plate facing p. 870 ; T. Haneda, Haneda Hakushi Shigaku Ronbunshū, I. fig. 2 ; PSPT, p. 23, fig. 4. 
IV. Bank-notes

43. Chih-yüan pao-ch'ao 至元寶鈔

(1) ? -1294, (4) Academia Sinica (Peking) and Asiatic Museum (Leningrad), (5) *PSPT, pp. 24-5, plates 1, 2 ; Kadokawa Shoten, op. cit., pp. $175-6$.

44. Chung-wen Yülan-pao, chiao-ch'ao 中紋元寶, 交鈔

(3) Tsinghai, (4) Shanghai Museum, (5)*WW, 171 (1965), p. 35, plate $\mathrm{V}, 2$ (illegible).

V. Coins

45. Ta-Yüan t'ung-pao 大元通寶

(5) Hsi-ch'ing hsï-chien (Taipei, 1965. new ed.), vol. 6. pp. 3747-9. ; * Pauthier, 'Rapport sur deux médailles'..', JA,V, 15 (1860), pp. 330-5, fig. on p. 332 ; Banaparte, op. cit, p. 5, plate XV, 2 ; * Han Ju-lin, 'Passu-pa-tzu Ta-Yüan t'ung-pao pa', Chung-kuo Wen-hua Yen-chiu-so Huik'an, III (1943), pp. 361-64 ; *Kadokawa Shoten, op. cit., p. 174 ; *PSPT, pp. 25-7, fig. 5 (left).

46. Chih-yïan t'ung-pao 至元通寶 (1)

(5) Bonaparte, op. cit., p. 5, plate XV, 2 ; *PSPT, pp.25-7, fig. 5 (right). 47. Chih-yüan t'ung-pao 至元通寶 (2) (with four inscriptions in Chinese, 'Phags-pa, Hsi-hsia and Persian)

(5) *Wang Chin-ju, 'Shih Ting-hai Fang-shih so-tsang ssu-t'i Chih-yüan t'ung-pao ch'ien-wen', $A S$, III, 2 (1931), pp. 277-8.

48. Chih-cheng t'ung-pao 至正通寶 (5) *WW, 171 (1965), p. 62.

VI. Balances

49. (?)-chin-p'ing $\square$ 斤科

(1) 1300 and 1321, (4) Lu Ho-chiu, (5) *PSPT, p. 28, plate 3.

VII. Texts of the Po-chia-hsing 百家姓

50. Po-chia-hsing

(1) 1340 (ed.), (4) Peking University, (5) PSPT, pp. 57-67.

51. Po-chia-hsing

(1) 1531 (ed.),(5) T'ang Ching-ch'uan pai-pien 唐荊川稗編； J. Edkins, 'Sanscrit and Mongolian characters', Transactions of the China Branch 
of the Royal Asiatic Society, V (1855), pp. 110-8, 4 plates.

52. Po-chia-hsing

(1) 1699 (ed.), (4) Library of the Academia Sinica (Peking), (5) PSPT, pp. 69-82.

53. Po-chia-hsing.

(1) 1699(ed.), (4) Kunaishō Zushoryō (Tokyo), (5) Ligeti, 'Le Po kia sing en écriture 'phags-pa', $A O H$, VI (1956), pp.1-52 (pp. 49-52, plates).

VIII. Texts of the Meng-ku Tzu-yiin 蒙古字䫓

54. Meng-ku Tzu-yün

(1) 1736-95 (copied), (4) British Museum, (5) Kansai Daigaku Tōzai Gakujutsu Kenkyujo, Eiin Daiei Hakubutsukan-zō kyü shōhon Mōkojiin (Osaka, 1956), 123 pp. ; PSPT, pp. 95-127.

\section{(B) 'PHAGS-PA MATERIALS IN MONGOLIAN}

I. Inscriptions

\section{The Edict of Mangala}

(1) 1276, (5) Chavannes, op. cit., pp. 376 81, plate 19;* Poppe, op. cit., pp. 46-7, plate I [Chinese text is in Ts'ai Mei-piao, Yüan-tai Pai. hua-pei Chi-lu, No. 23].

\section{The Edict of Buyantu Qan}

(1) 1314, (5) Chao Han, Shih-mo Chiian-hua (Chih-pu-tsu-chai Ts'ungshu ed.) vol. 6, pp. 11b-14b. ; * von der Gabelentz, 'Versuch über eine alte mogolische Inschrift', $Z K M$, II, 1 (1839), pp. 4-13, Tables I, III ; * Wylie, 'Sur une inscription mongole...', $J A, \mathrm{~V}, 19$ (1862), reproduction facing p. 465 ; Bonaparte, op. cit., plate XII, 3 ; ${ }^{*}$ Devéria, 'Notes d'épigraphie mongole-chinoise', JA, IX, 7-8 (1896), pp. 94-128; Chavannes, ibid. TP, II, 5 (1904), pp.422-6 ; * Lewicki, Les inscriptions mongoles inédites en écriture carrée, pp. 20-3; *Poppe, ibid., pp. 48-50, plate II.

57. The Edict of Buyantu Qan

(1) 1314, (2) Honan, An-yang, (5) Chavannes, ibid., TP, IX(1908), pp. 
407-3, plate 24 ; * Poppe, ibid., pp. 51-3, plate III; Ts'ai Mei-piao, op. cit., p. 67 , plate 4 .

58. The Edict of Dharmapala's Widow

(1) 1321, (4) Oriental Library of the Leningrad University, (5) A.A. Bobrovnikov, 'Gramoty vdovy Darmabalovoj i Bujantu-Xana, pisannyja kvadratnym' pis'mon", TVOIRAO, XVI (1872) [not seen];* Poppe, ibid., pp. 54-5, plate IV ; Simon, op. cit., p. 205, plate III (b) [only the top of this epigraph] ; *Haarh, op.cit., p. 60, fig. 4 [only the top of this epigraph].

59. The Edict of Ananda

(1) 1283, (5) Bonaparte, op.cit,. plate XII, 1 ; * Poppe, ibid., pp. 56-7, plate V.

60. The Proclamation

(1) 1306, (5) Chavannes, op.cit., pp. 320-3, plate 2; *Poppe, ibid., p. 57, plate VI.

61. The Proclamation

(1) 1307 , (5) Chavannes, ibid., pp. 323-4, plate 3 ; Cheng Tsai-fa, op. cit., plate 6 [The 'Phags-pa inscription of this epigraph is exactly the same as item 57.].

62. The Proclamation

(1) 1294 , (5) Chavannes, ibid., pp. 325-9, plate 4 [The inscription is also exactly the same as item 57.].

63. The Proclamation

(1) 1365 (or 1377), (2) $0.82 \mathrm{~m} . \times 0.64 \mathrm{~m}$., (3) Shansi Province, Shanpi-shan, Hsüan-chung-ssu Temple, (4) ditto, (5)* Ozawa, 'Sansei-shō Kōjō-ken Sekiheki-zan Genchū-ji no Pasupamoji Mōkogo hibun no kaidoku,' Tōkyō Gaikokugo Daigaku Ronshū, 9 (1962), pp. 9-33+1 plate.

64. The Chï-yung-kuan Inscription 居庸關碑文

(1) 1345 , (2) $1.55 \mathrm{~m} . \times 1.58 \mathrm{~m}$. (both walls), (3) Hopei, Chü-yung-kuan, (5)* Wylie, 'On an ancient Buddhist inscription at Keu-yung kwan,' $J R A S$, n. s. V (1870), restoration after p. 44; Bonaparte, op. cit., plates I, III, IV; Sekino and Tokiwa, Shina Bukkyo Shiseki, vol. V, plates 128-30; * Poppe, ibid., pp. 60-6, plate II ; J. Murata (ed.), Kyoyzkan, vol. II, plates 59-63, 91-2. 
65. The Edict of Kuang-kuo-ssu Temple

(1) 1318 , (3) Shensi, Ko-yang-hsien, (5) Chavannes, op. cit., plate XXV ; * Yamasaki, ' 1318 nen no Pasupaji Mokogo hibun kaidoku', $G K, 26 / 27$ (1954), pp. 111-9 (reproduction is on p. 113); Cheng Tsaifa, op. cit., plates 4,5 (illegible).

66. The Edict of the Ch'ung-yang-kung at Chou-chih

(1) 1350 ?, (3) Shensi, Chou-chih, (4) Ethnological Museum of Berlin,

(5) * Haenisch, Steuergerechtsame der chinesischen Klöster unter der Mongolenherrschaft, pp. 58-9, plate I.

67. Ditto

(1) 1351, (3) Shensi, Chou-chih, (4) Ethnological Museum of Berlin,

(5) * Haenisch, ibid., pp. 59-60, 63-4, plate II ; *Han Ju-lin, 'Ch'eng-tu Meng-wen sheng-chih-pei k'ao-shih', Studia Serica, II (1941), pp. 136-49. 68. Ditto

(1) 1352, (3) Shensi, Chou-chih, (4) Ethnological Museum of Berlin, (5) *Haenisch, ibid., pp. 60-1, 65-6, plate III.

II. Seals

69. Seal of Nomci mergen mkhan-po

(2) $1 \frac{5}{16}$ in. square, (3) Darjeeling, (4) Forbes-Tweedie (?), (5)* Clauson, 'A Mongolo-Tibetan seal', JRAS, 1929, pp. 117-9, [The last line is written in Tibetan.].

70. Seal of Galdan Boshogutu

(5) *Krueger, 'Three Oirat-Mongolian Diplomatic Documents of 1691', $C A J$, XII, 4 (1969), p. 289.

III. P'ai-tzu

71. The Minusinsk p'ai-tzu

(3) Minusinsk, (4) The Hermitage Museum (Leningrad), (5) Yule, The Book of Ser Marco Polo, I, plate facing p. 352 ; Yanai, op.cit., plate facing p. 894; Haneda, op. cit., fig. 1 ; *Poppe, op. cit., p. 57, plate VII.

72. The Nyuki p'ai-tzu

(3) Nyuki, (4) The Hermitage Museum, (5)*Poppe, ibid, p. 58, plate VIII.

73. The Bogotol p'ai-tzu

(3) Bogotol, (5) A. M. Pozdneyev, 'Ob'jasnenie drevnej mongol'skoj 
nadpisi na čugunnoj doščečky, dostavlennoj v Imp. Akad. Nauk' G. Vinokurovym", ZIAN, 39 (1881) [not seen]; Haneda, ibid., fig. 6, pp. 113-4; * Poppe, ibid., p. 58, plate IX.; Kadokawa Shoten, op. cit., p. 172.

74 The Mongolian-Persian-Chinese $p^{\prime} a i$-tzu

(3) near Peking, (4) Institute of Oriental Studies of the Academy of Sciences of the USSR, (5) Haneda, ibid., fig 5 ; *Poppe, ibid., p. 58, plate X; Kadokawa Shoten, ibid., p. 172.

IV. Documents

75. The Edict of Hai-ning-wang 海密王諮旨

(1) 1305, (5)*Pelliot, op. cit., TPS, II, pp. 621-4.

76. Fragment of the Subhạsitaratnanidhi (1) (= The Mannerheim Fragment) (3) East Turkestan, (4) Société Finno-Ougrienne (?), (5) Ramstedt, 'Ein Fragment mongolischer Quadratschrift', JSFOu, XXVII, 3 (1911), pp. 1-4.; * Aalto, 'The Mannerheim fragment of Mongolian 'Quad. ratic' script', SO, XXII, 7 (1952), pp. 1-9; *Poppe, op.cit., p.59, plate XI. 77. Ditto (2)

(5) Carter, The Invention of Printing in China and its Spread Westward, plate facing p. 120 ; *Aalto, 'A second fragment of the Subhāṣitaratnanidhi', JSFOu, LVII, 5 (1954), pp. 1-6;

78. The Turfan fragment

(3) Turfan, (4) Ethnological Museum of Berlin, (5) *Aalto, ' $\mathrm{Zu}$ den Berliner Turfan-Fragmenten T III D 322', JSFOu, LXI, 6 (1959), pp. 3-21.

I. Seals

\section{(C) 'PHAGS-PA MATERIALS IN TIBETAN}

79. Seal of Dalai Lama (1)

(5) Waddell, Lhasa and its Mysteries, p. 449; *Walsh, 'The coinage of Tibet', $M A S B$, II, 2 (1907), pp. 16-7; * Francke, 'Note on the Dalai Lama's seal and the Tibeto-Mongolian characters', JRAS, 1910, p.1206. [As to the decipherment of this seal, see the following works as well: Bushell, Review of Waddell, op.cit., JRAS, 1906, p. 478; Waddell, 'Seal of the Dalai Lama', JRAS, 1911, pp. 204-6; Francke, 'The Dalai Lama's seal', JRAS, 1911, pp. 528-30.]

80. Seal of Dalai Lama (2) 
(5)*Francke, 'Another version of the Dalai Lama's seal', $J R A S, 1912$, pp. 746-7.

81. Seal of Rnam-rgyal

(5)*Francke, 'Note on the Dalai Lama's seal..., p. 1206, fig. 4.

82. Seal of Prime Minister (1)
(3) Darjeeling, (5)*Walsh, 'Examples of Tibetan seals', JRAS, 1915, pp. 5-7.

83. Seal of Prime Minister (2)

(5)* Walsh, ibid., pp. 7-8.

84. Seal of The Tibetan Council of Ministers

(5)*Walsh, ibid., p. 9, fig. 6.

85. Seal of Bka'-blon Bla-ma

(5)*Walsh, ibid., pp. 9-10, fig. 8 .

86. Seal of Tsogs-'du dud-pa

(5) ${ }^{*}$ Walsh, ibid., pp. 9-10, fig. 7.

87. Seal of Rjon-dpon (1), (2)

(5)*Walsh, ibid., pp. 10-11, fig. 9 .

88. Seal of the Abbot of the Gyantse Monastery

(5) *Walsh, ibid., p. 11.

89. Seal of the Tibet Joint Trade Agent at Gyantse

(5)*Walsh, ibid., pp. 11-12.

90. Seal of the Kyab.dpin

(5) Walsh, ibid., p. 12, fig. 10 (indecipherable).

91. Private Seal of Dalai Lama

(5) Walsh, ibid., pp. 4-5, fig. 3 (indecipherable)

92. Seal of the 'Bras-spun Monastery

(5)*Walsh, ibid., p. 15.

93. Seal of Sera Monastery

(5)*Walsh, ibid., p. 15 (partly illegible).

94. Seal of Dga'-ldan Monastery

(5)*Walsh, ibid., p. 15.

95. Seal of Dalai Lama (3)

(1) 1741, (5)*Walsh, 'Examples of Tibetan seals : Supplementary Note', JRAS, 1915, pp. 466-8. 
96. Smaller Seal of the Regent of Lhasa

(1) 1741, (5) Walsh, ibid., p. 469 (illegible).

97. Larger Seal of the Regent Lhasa

(1) 1741 , (5) Walsh, ibid., p. 470 (indecipherable).

98. Seal of Bhutan

(5)*Francke, 'Ein Siegel in tibeto-mongolischer Schrift von Bhutan', ZDMG, LXIV (1910), pp. 553-4.

99. Seal of Nomcii mergen mkhan-po

[see item 69.]

100. Seal of Qan Olan-a ergügdegsen

(5)*Rintchen, 'A propos de la sigillographie mongole', $A O H$, III (1953)

pp. 27, 30 .

II. Block-prints

101. Rgya-dkar-nag rgya-ser ka-smi-ra bal bod hor-gyi yi-ge dan dpe-ris rnam-gran்s man்-ba, fols. 14a, 14b, 15a

(1) early nineteenth century (?), (3) printed in Peking, (4) National Library of Germany (Berlin); Library of the Hungary Academy of Sciences (Budapest); The Australian National University Library (Canberra); Sakai Collection (Kōyasan); Nagao Collection (Kyōto); Asiatic Museum (Leningrad); Lokesh Chandra Collection (New Delhi); Library of the Oriental Institute, Czechoslovakian Academy of Sciences (Prague), (5) Das, 'The sacred and ornamental characters of Tibet', $J A S B$, LVII (1888), plates V (b), (e), VII, No. 1; * Francke, 'Note of the Dalai Lama's seal..., p. 1203 ; * Nakano, 'Rgya-dkar-nag...ni tsuite ...', THG, 36 (1958) pp. 149-134, plate. ; Nakano, 'On the Rgya-dkar-nag... and some remarks on the 'Phags-pa script', Indo.Asian Studies, part 3 (1971) pp. 1-16, plate.

102. A 'Phags-pa specimen

(4) E. Teramoto, (5) Teramoto, Chibettogo Bunpo, the 3rd plate after the title page; W. Simon, op. cit., plate III (c).

\section{(D) 'PHAGS.PA MATERIALS IN OTHER LANGUAGES}

I. Sanskrit

103. Epigraph of Mo-kao-k'u 莫高窟碑 (The Thousand Buddhas in Tunhuang) 
(3) Kansu, Tun-huang, (4) Academia Sinica (Taipei), (5) Hsieh Chihliu, Tung-huang I-shu Hsï-lu (Shanghai, 1955), plate 1; P'an Hsieh-tzu, Tun-huang Mo-kao-k'u I-shu (Shanghai, 1957), p. 24 ; Kadokawa Shoten, op. cit., p. 181 ; Cheng Tsai-fa, op. cit., plate I. [This epigraph is written in the six scripts: Lañtsha, Tibetan, Uighur, 'Phags-pa, Hsihsia and Chinese. The dhârañ $\bar{\imath}$ of this epigrph can be read as $O m$ mañi padme hüm]. 


\section{BIBLIOGRAPHY}

This bibliography is intended to complement the bibliography edited and revised by N. Poppe and J. R. Krueger added to N. Poppe's The Mongolian Monuments in liP' ags-pa Script (1957). Russian works which are mentioned in Poppe's bibliography are not included in this bibliography. Reviews are also excluded other than a few which seem to be specially important. Entries referring to the Chinese language, especially Middle Chinese, are mainly limited to those quoted in this paper.

\section{A Biography of Bla-ma 'Phags-pa.}

AN, Shou-jen 安守仁, 'Pa-ssu-pa ch'ao-chien Hu-pi-lieh pi-hua 八思巴朝 見忽必烈壁畫’, $W W, 107$ (1959), pp. 12-3.

BACOT. J., Introduction à l'histoire du Tibet (Paris: Société Asiatique, 1962), pp. 4E-9.

BELL, C., The Religion of Tibet (Oxford: Clarendon Press, 1931),pp.65-6.

CH'EN, T'ien-ou 陳天臤, La-ma-chiao-shih lïeh 喇蝶较史略 (=Pien-ch'iang Ts'ung-shu)(Taipei : Chung-yang Wen-wu Kung-ying-she,1954), pp. 25-7. $\mathrm{CH}^{\prime} \mathrm{EN}$, Yin-k'o 陳寅恪, 'Chang-so-chih lun yü Meng-ku Yüan-liu 彰所知論 與蒙古源流', AS, II, 3 (1931), pp. 302-9.

CHI, Yün 紀昀 and others, Meng-ku Yüan-liu Chien-cheng 蒙古源流箋證 annotated by SHEN Tseng-chih 沈曾植 and CHANG Erh-t'ien 張雪田 (Taipei : Wen-hai Ch'u-pan-she, 1965. repr. based on the Ch'an-shouchai chiao-ting-pen 序守弯校訂本, 1789 ed.) pp. 171-81.

[Chinese tr. of the Erdeni-yin Tobzi]

DAS, S.C., 'Contribution on the religion, history, etc. of Tibet', JASB, L, 1 (1881), pp. 187-251, esp. pp. 240-1.

D'OHSSON, C., Histoire des Mongols, depuis Tchingguiz-Khan jusqu' Timour bey Tamerlan (La Haye et Amsterdam: Les Frères van Cleef, 1834), Livre III, pp. 370-2.

FERRARI, A., Mk'yen Brtse's Guide to the Holy Places of Central Tibet (=Serie Orientale Roma, XVI) (Roma: Istituto Italiano per il Medio ed Estremo Oriente, 1958), pp. 62-4, 102, 147, 150-1. 
GABAIN, A. von, 'Der Buddhismus in Zentralasien', Religionsgeschichte des Orients in der Zeit der Weltreligionen $(=$ Handbuch der Orientalistik, Band 8, Abschnitt 2) (Leiden/Köln : E. J. Brill, 1961), pp. 497-514, esp. p. 512 .

Gō, Minoru 江實, Mōko Genry $\bar{u}$ Yakuchū 蒙古源流譯註 (Tokyo: Kōbundō, 1940), pp. 70-5. [First published in the Zenrin Kyōkai Chōsa Geppō 善隣 協會調查月報, 1937,Dec.-1939, Jan.] [Japanese tr. of the Erdeni-yin Tob $i$ ] GOMBOJ̆AB (Tib. Mgon-po skyabs), 'Tsao-hsiang-liang-tu-ching yin 造像量度經引,' Taishō, No. 1419, vol. XXI, p. 939a.

'GOS-LO-TSA-BA GŹON-NU-DPAL, Bod-kyi yul-du chos dan chos-smraba ji-ltar byun-ba'i rim-pa Deb-ther snon-po, or in short Deb-ther snon-po. See Roerich, below.

GRÜNWEDEL, A., Mythologie du Bouddhisme ou Tibet et en Mongolie (Leipzig: F.A. Brockhaus, 1900), p.55, Fig. 41(=Portrait of 'Phags-pa), p. 53, Fig. 44, pp. 65-7,107,179, 208. [French tr. of Mythologiedes Buddhismus in Tibet und der Mongolei (Leipzig: F. A. Brockhaus, 1900), tr. by I. Goldschmidt]

HACKIN, J., Guide-Catalogue du Musée Guimet. Les Collections Bouddhiques(Paris/Bruxelles: Librairie Nationale d'Art et d'Histoire, 1923), pp. $66,110$.

- , 'Mythologie du lamaisme', Mythologie asiatique illustrée (Paris: Librairie de France, 1928), pp. 121-62.

HASHIMOTO, Kōhō 橋本光璸, 'Fubirai-kan to Ramakyō フビライ汗とラ จ数,'Mōko, VIII, 6 (1941), pp. 26-32.

- - , Mōko no Ramakyō 蒙吉の喇䧸数 (Tokyo: Bukkyō Kōronsha, 1942), pp. 30, 66-8, 140-1.

HOFFMANN, H., Die Religionen Tibets Bon und Lamaismus in ihrer geschichtlichen Entwicklung (Freiburg/München: Karl Alber, 1956), pp. 132-5.

HSIANG-MAI 稀遏, Chih-yüan Pien-wei-lu 至元㦚傜錄, Taishō, No, 2116, vol. LII, pp. 751-81.

HUAN-LUN 幻輸, Shih-chien Chi-ku-lüeh hsü-chi 釋鑑秷古略續集, Taisho, No. 2038, vol. XLIX, pp. 903-6.

HUTH, G., 'Hor c'os byun: Geschichte des Buddhismus in der Mongolei, in tibetischer Sprache', Transactions of the Ninth International 
Congress of Orientalists, vol. II (London, 1893), pp. 636-41.

- - Geschichte des Buddhismus in der Mongolei. Mit einer Einleitung:

Politische Geschichte der Mongolen, Teil II (Strassburg: K. J. Trübner, 1896), pp. 118-67.

INABA, Masae 稻葉正枝, 'Gen no Ramaso Tanpa ni tsuite 元のラマ僧能 巴について', $I B K, \mathrm{XI}, 1$ (1963), pp. 180-2.

INABA, Shōju 稳葉正就, 'Gen no teishi ni tsuite — Orānshi o shiryō to shite一一元の帝師に就いて—ーオーン串を資料として'，IBK, VIII, 1 (1930), pp. 26-32.

- - 'The Lineage of the Sa skya pa. A Chapter of the Red Annals', Memoirs of the Research Department of the Tōyo Bunko, No. 22(1963), pp. 107-23. [English tr. of the Hu-lan deb-ther, Chapter V]

- -, 'Gen no teishi ni kansuru kenkyū — Keitō to nenji o chūshin to shite一一元の帝師に關する研究 — - 系統と年次を中心として'，ODKN， XVII (1964), pp. 80-156.

- - , and SATŌ, Hisashi 佐藤長, Hu-lan deb-ther ...... Chibetto Nendaikr フウランテプテルーーチベット年代記 (Kyōto: Hōzōkan, 1964), pp. 118-9, 133. [Japanese tr. of the Hu-lan deb-ther]

'JIGS-MED RIG-PA'I RDO-RJE, Hor-chos-byun. See item of HUTH, G. K'O, Shao-min 柯妿密, Hsin Yüan-shih 新元史, fasc. 140. 'Shih-Lao chuan 釋老傅' (25-shih ed., vol. VIII), pp. 461-2.

KOEPPEN, C. F., Die lamaische Hierarchie und Kirche (=Die Religion des Buddha und ihre Entstehung, Band II) (Berlin: H. Barsdorf, 1906, 2nd. ed.), pp. 96-100.

KOLMAŠ, J., Tibet and Imperial China. A Survey of Sino-Tibetan Relations up to the End of the Manchu Dynasty in 1912(=Occasional Paper, 7) (Canberra: The Australian National University, 1967), pp. 20-2.

KRAUSE, F.E.A., Ju-Tao-Fo. Die religiosen und philosophischen Systeme Ostasiens (München: E. Reinhardt, 1924), pp. 484, 585. Reviewed by P. Pelliot, TP, 'XXIII (1924), pp. 54-62.

KRUEGER, J. R., History of the Eastern Mongols to 1662 (Erdeni-yin Tobci) (= The Mongolia Society Occasional Papers, No. 2) (Blooming. ton: The Mongolia Society, 1967, 2nd ed.), pp. 73-7.

KUN-DGA' RDO-RJE, Hu-lan deb-ther / Deb-ther dmar-po (= The Red 
Annals), Part I (Gangtok : Namgyal Institute of Tibetology, 1961), fol. $22 \mathrm{a}$.

NAKANO, Miyoko 中野美代子, 'Ti-shih Pa-ssu-pa hsing-chuang chiao-cheng 帝師八思巴行狀校登', $H Y H P$, vol. IX, 1 (1969), pp. 93-119.

NIEN-CH'ANG 念常, Fo-tsu Li-tai T'ung-tsai 俳租歷代通載（Taishō,No. 2036, vol. XLIX).

The following chapters are included in the above:

a) WANG, P'an 王磐 and others, 'Hsing-chuang 行狀', ibid., fasc. 21 (Taishō, XLIX, 707b-c).

b) SHIH-YƯAN Tsung-chu 釋源宗主, 'Ti-shih Tien-pei 帝師殿碑,' ibid., fasc. 22 (Taishō, XLIX, 732-3).

NOGAMI, Shunjō 野上俊静 and INABA, Shōju, 'Gen no teishi ni tsuite 元の帝師に就いて', Ishihama Sensei Koki Kinen Tōyoggaku Ronsō 石濱 先生古稀記念東洋學論叢 (Osaka: Kansai University, 1958), pp. 433-48.

OKADA, Hidehiro 岡田英弘, “Mōko shiryō ni mieru shoki no Mō-Zō kan-

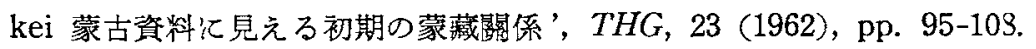

PETECH, L., Mediaeval History of Nepal (= Serie Orientale Roma, X, 3)

(Roma: Istituto Italiano per il Medio ed Estremo Oriente, 1958), pp. 99-101.

- -, 'Tibet', Geschichte Mittelasiens (=Handbuch der Orientalistik, Band 5, Abschnitt 5) (Leiden/Köln: E. J. Brill, 1966), pp. 311-47, esp. pp. 329-30.

RATCHNEVSKY, P., 'Die mongolischen Grosskhane und die buddhistische Kirche', Asiatica. Festschrift Friedrich Weller zum 65. Geburtstag (Leipzig: O. Harrassowitz, 1954), pp. 489-504, esp. pp. 492-5.

ROERICH, G.N. de, The Blue Annals(=The Royal Asiatic Society of Bengal Monograph Series, vol. VII) (Calcutta: The Society, 1949-1953), I, pp. 210-12. [English tr. of the Deb-ther snion-po]

SA $\Upsilon$ AN SEČEN QONG TAYIJ̌I, Erdeni-yin Tobci. See Chi, Gō and Schmidt. SCHMIDT, I. J., Geschichte der Ost-Mongolen und ihres Fürstenhauses, (St. Petersburg: N. Gretsch/Leipzig: C. Cnobloch, 1829), pp. 111-19, 391-8. [German tr. of the Erdeni-yin Tob̌̌i]

SCHULEMANN, G., Die Geschichte der Dalai-Lamas (Leipzig: O. Harrassowitz, 1953), pp. 92-5, 176, 209. [Orig.ed.=Religionswissenschaftliche Bibliothek, 3 (Heidelberg: Carl Winter, 1911).] 
SHAO, Yüan-p'ing 驾遠平, Yüan-shih Lei-pien 元史類編 (Ch'ien-lung ed. published by Sao-yeh Shan-fang 掃葉山房), fasc. 41, 'Tsa-hsing chuan 雜行傳'。

SHEN, Tsung-lien 沈先灌 and LIU, Sheng-ch'i 柳阵祺, Tibet and the Tibetan (Stanford: Stanford University Press,1953), p. 39.

STEIN, R.A., La civilisation tibétaine (=Collection SIGMA dirigée par Henri Hierche, I) (Paris: Dunod, 1962), pp. 55-6.

SUNG, Lien 宋庵 and others, Yïan-shih 元史, fasc. 202, 'Shih-Lao chuan 釋老傳' (25-shih ed. vol. VIII), pp. 454-5.

TE.HUI Ch'an-shih 德輝稆師, Ch'ih-hsiu Po-chang Ch'ing-kuei 勅修百丈清規, fasc. 2, 'Ti-shih Nieh-p'an 帝師涅槃' (Taishō, No. 2025, vol. XLIIX, pp. $1117 \mathrm{a}-\mathrm{c})$.

TUCCI, G., Tibetan Painted Scrolls, II (Roma: La Libreria dello Stato, 1949), pp. 625-51.

- - The Tombs of the Tibetan Kings (=Serie Orientale Roma, I)

(Roma: Istituto Italiano per il Medio ed Estremo Oriente, 1950),p. 11.

WADDELL, L.A., The Buddhism of Tibet or Lamaism, with its mystic cults, symbolism and mythology, and its relation to Indian Buddhism (London: W.H. Allen, 1895), pp. 38, 576 (=chronological table).

YAZAKI, Shōen 矢崎正見, 'Pakupa no kyōgaku ni tsuite パクパの数學江 วいて', IBK, VII, 1 (1958), pp. 241-4.

\section{II. 'Phags-pa Script.}

AALTO, P., 'Altaistica I. The Mannerheim fragment of Mongolian “Quadratic" script,' SO, XVII, 7 (1952), pp. 1-9.

- , 'A second fragment of the Subhāșitaratnanidhi in Mongolian quadratic script,' JSFOu, LVII, 5 (1954), pp. 1-6.

- - 'Fragmente des mongolischen Subhāṣitaratnanidhi in Quadratschrift', MIO, III, 2 (1955). pp. 279-90.

- ' ' $\mathrm{Zu}$ den Berliner Turfan-Fragmenten T III D 322', JSFOu, LXI, 6 (1959), pp. 3-21.

- - 'Quadrat-Inschriften', Mongolistik (=Handbuch der Orientalistik, Band 5, Abschnitt 2)(Leiden/Köln: E. J. Brill, 1964), pp. 104-7.

ABEL-REMUSAT, J.P., Recherches sur les langues tartares ou Mémoires sur differents points de la Grammaire et de la Littérature des Man- 
dchous, des Mongols, des Ouigours et des Tibétains, vol. I (Paris, 1820), pp. 197-214.

- , 'Tha-tha-toung-'a, Ministre ouïgour', Nouveaux mélanges asiatiques, II (Paris, 1829), pp. 61-3.

BACOT, J., Grammaire du tibétain littéraire, I (Paris: Librairie d'Amś. rique et d'Orient, 1946), p. 83.

BANZAROV, D., 'Erklärung einer mongolischen Inschrift auf einer im Jekaterinoslawschen Gouvernement auf den Gütern des Herrn Barons A. von Stieglitz ausgegrabenen Silberplatte', Bulletin, V, 9 (1848), Sp. $129-39+1$ table.

- ' 'Uber zwei mittelasiatische Alphabete. Mit einer Nachschrift von O. Böhtlingk', Bulletin, V, 4 (1848), Sp. 49-57+1 table.

BEAL, S., 'The Buddhist inscription at Kiu-yung-kwan,' Indian Antiquary, IX (1880), p. 195.

BÖHTLINGK, O., 'Über einige Sanskrit-Werke in der Bibliothek des Asiatischen Departements', Bulletin;, II, 22 (1845), Sp. 342-3 (=Nos. $574,590)$.

BONAPARTE, Prince R. N., Documents de l'époque mongole des XIII et $X I V^{\prime}$ siecles. Inscriptions en six langues de la porte de Kiu-yong Koan, près Pekin ; lettres steles et monnaies en écritures oügoure et 'Phags-pa dont les originaux ou le estampages existent en France (Paris: published by the author, 1895), II +5 pp. +15 plates.

BOSSON, J.E., 'A rediscovered xylograph fragment from the Mongolian 'Phags-pa version of the Subhāṣitaratnanidhi', CAJ, VI (1961), pp. 85102.

CARTER, T.F., The Invention of Printing in China and its Spread Westward (New York: Columbia University Press, 1925), plate facing p. 120 ; ibid. (2nd ed. and rev. by L.C. Goodrich) plate facing p. 121, p. 146.

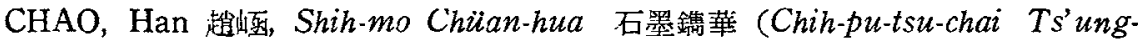
shu ed.), vol. 6, pp. 11b-14b.

CHAVANNES, E., 'Note préliminaire sur l'inscription de Kiu-yong Koan,

I. Les inscriptions chinoises et mongoles ', $J A$, IX, 4(1894), pp. 355-58. - -, 'Le Sütra de la paroi occidentale de l'inscription de Kiu-yong Koan', Mélanges Charles de Harlez. Recueil de Travaux d'Érudition 
offert à Mgr. Charles de Harlez à l'occasion du vingt-cinquième anniversaire deson Professor at dे l'Université de Lowvain 1871-1896(Leyde: E. J. Brill, 1896), pp. 60-81.

- - 'Note sur une amulette avec inscriptions en caractères Pa-sepa ', JA, IX, 1 (1897), pp. 148-9.

- , 'Inscriptions et pièces de chancellerie chinoise de l'époque mongole', $T P, \mathrm{~V}$ (1904), pp. 357-447; ibid., VI (1905), pp. 1-42; ibid., IX (1908), pp. $297-428+30$ plates.

- - 'Notes sinologiques, II. Un passage d'un édit de BouiantouKhan', BEFEO, IV (1904), pp. 81-2.

CHENG, Tsai-fa 鄭再發, Meng-ku Tzu-yün ken ken Pa-ssu-pa-tzu yu-kuan te yün-shu 蒙占字䫓跟跟八思巴字有關的頱書 (=Kuo-li T'ai-wan Tahsïeh Wen-shih Ts'ung-k'an, 15) (Taipei : Taiwan University, 1965),4+ $110+(1$ table $)+5$ pp.

- - , ‘Pa-ssu-pa-tzu piao-chu Han-yü ts'ai-liao chiao-k’an chi 八思巴字標 注漢語材料校勘記', Symposium in Honor of Dr. Li Chi on his Seventieth Birthday, Part II (Taipei: Academia Sinica, 1967), pp. 933-1003+6 plates.

ClAUSON, G.L.M., 'A Mongolo-Tibetan seal', JRAS, 1929, pp. 117-19.

- - , 'The hP'ags-pa alphabet', BSOAS, XXII (1959), pp. 300-23.

- -, Turkish and Mongolian Studies (=Prize Publication Fund, vol. $\mathrm{XX}$ ) (London: The Royal Asiatic Society of Great Britain and Ireland, 162), pp. 189-91.

CLAUSON, G.L.M. and YOSHITAKE, S., 'On the phonetic value of the Tibetan characters $W$ and $\beta$ and the equivalent characters in the $h$ Phags.pa alphabet', JRAS, 1929, pp. 843-62.

CLEAVES, F.W., 'The Sino-Mongolian inscription of 1362 in memory of Prince Hindu', HJAS, XII (1949), pp. 1-133+37 plates.

- - 'The Sino-Mongolian inscription of 1335 in memory of Chang Ying-jui ', HJAS, XIII (1950), pp. 1-131+35 plates.

- - 'The Sino-Mongolian inscription of 1338 in memory of Jigüntei', HJAS, XIV (1951), pp. 1-104 +32 plates.

- - 'The Sino-Mongolian inscription of 1346', HJAS, XV (1952', pp. 1-123+12 plates.

- , 'The Mongolian documents in the Musée de Téhéran', HJAS, 
XVI (1953), pp. $1-107+2$ plates.

DAS, S.C., 'The sacred and ornamental characters of Tibet', JASB, LVII (1888), pp. $41-8+9$ plates.

DENLINGER, P.B., 'Chinese in hP'ags-pa script', $M S$, XXII (1963), pp. 407-33.

DEVÉRIA, G., 'Notes d'épigraphie mongole-chinoise', $J A$, IX, 7, 8 (1896), pp. 94-128, 395-443; 'Addenda et corrigenda', ibid., IX, 9 (1897), pp. 183-4.

DIRINGER, D., The Alphabet. A Key to the History of Mankind (London: Hutchinson Scientific and Technical Publications, 1948, 2nd. and rev. ed.), pp. 318, 330, 355.

DRAGUNOV, A., 'The $h$ Phags-pa script and Ancient Mandarin', IAN, VII (1930), pp. 627-47, 775-97. [Chinese tr. : Lung Kuo-fu 龍果夫 (Dragunov), $P a$-ssu-pa-tzu $y \ddot{u} K u$ Han-y $\ddot{u}$ 八思巴字與古漢語, tr. by T'ANG, Yü 唐處 (Peking: K'o-hsüeh Ch'u-pan-she, 1959), 46 pp.]

DROUIN, E., 'Notice sur les monnaies mongoles, faisant partie du Recuil des documents de l'époque mongole publié par le Prince Roland Banaparte', JA, IX, 3 (1896), pp. 486-544.

DULAURIERS, E., 'Les mongols d'après les historiens arméniens, fragments traduits sur les textes originaux', $J A, \mathrm{~V}, 11-12$ (1858), pp. 192255, 426-73, 481-508.

EDKINS, J., 'Sanscrit and Mongolian characters', Transactions of the China Branch of the Royal Asiatic Society, Part V (Hong Kong, 1855), pp. 101-8+4 tables.

FENG, K'uan 奉寬, 'Chü-yung-kuan Yüan-k'o chou-sung-yin pu-fu-k'ao 居庥關元刻呪頌昔補附考'，Shih-hsüeh Nien-pao, II, 1 (1934), pp. 45-55. FEVRIER, J. G., Histoire de l'écriture (Paris: Payot, 1948), p. 308.

FRANCKE, A. H., 'Ein Siegel in tibeto-mongolischer Scrift von Bhutan', ZDMG, LXIV (1910), pp. 553-4.

- - ' Note on the Dalai Lama's seal and Tibeto-Mongolian characters', JRAS, 1910, pp. 1205-14.

- - , 'The Dalai Lama's seal', JRAS, 1911, pp. 528-30.

- - , 'Another version of Dalai Lama's seal', JRAS, 1912, pp. 746-8.

GABELENTZ, H. C. von der, 'Versuch über eine alte mongolische Inschrift', $Z K M$, II, 1 (1839), pp. $1-21+3$ tables. 
- -, 'Nachtrag zur Erklärung der altmongolischen Inschrift', $Z K M$, III (1840), pp. 225-7.

GRIGORIEF, V., 'Lettre adressée à la Société Asiatique de Paris sur l'origine et les monuments de l'écriture carrée, dont l'invention est attribuée au Pagba-lama', JA, V, 17 (1E61), pp. 522-58.

GULIK, R.H. van, Siddham. An Essay on the History of Sanskrit Studies in China and Japan (=Sarasvati Vihara Series, vol. 36) (Nagpur: International Academy of Indian Culture, 1956), pp. 98-100.

HAARH, E., 'L'écriture 'phags-pa vraiment carrée des sceaux chinois des Yüan', $A O, \mathrm{XXIV}, 1-2$ (1959), pp. 59-61+7 figs.

HAENISCH, E., 'Grammatische Besonderheiten in der Sprache des Monghol un Niuca Tobca'an', SO, XIV, 3 (1950), pp. 1-26.

- - Steuergerechtsame der chinesischen Klöster unter der Mongolenherrschaft. Eine kulturgeschichtliche Untersuchung mit Beigabe dreier noch unverc̈ffentlichter Phagspa-Inschriften (=Berichte über die Verhandlungen der Sächsischen Akademie der Wissenschaften zu Leipzig, Philologisch-historische Klasse, XCII, 2) (Leipzig: S. Hirzel, 1940), 74 pp. +4 plates. Reviewed by H. Schumann, HJAS, XIV (1951), pp. 291-306.

HAMBIS, L., Grammaire de la langue mongole écrite, première partie (Paris : Adrien-Maisonneuve, 1945), pp. XXI-XXII, 95-6 (=bibliography).

HAN, Ju-lin 韓需林, 'Ch'eng-tu Meng-wen sheng-chih-pei k'ao-shih 成都 蒙文聖旨碑考釋”, Studia Serica (Chengtu), II, 2 (1941), pp. 137-49.

- - , 'Pa-ssu-pa-tzu Ta-Yüan t'ung-pao pa 八思巴字大元通寶践', Chung. kuo Wen-hua Yen-chiu-so Hui-K'an 中國交化研究所㽞刊, III (1943), pp. $361-4$.

HANEDA, Tōru 坊田宁, 'Genchō ekiden zakkō 元朝礋傳雜考', Haneda Hakushi Shigaku Ronbunshū 炣田博士史學論文集, I (=Rekishi-hen) (Kyoto: Kyoto University, 1957), pp. 32-114, esp. pp. 92, 101, $113+$ plates 1, 2, 5, 6. [First written in 1930]

- - 'Genchō no Kan bunmei ni taisuru taido 元朝の漢文明飞對する態 度', ibid., pp. 671-96. [First published in the Kano Kyojju Kanreki Kinen Shinagaku Rons $\bar{o}$ 狩野教授還厤記念支那學論叢 (Kyoto：Kyoto University, 1928).] 
- -, 'Kanyaku no Butten ni tsuite 漢譯の佛典について', ibid., II (=Gengo, Shükyō-hen) (Kyoto: Kyoto University 1958), pp. 348-57. [First published in the Geibun, II, 2 (1911).]

HASHIMOTO, Mantarō J. 橋本萬太郎, 'Pasupa bun boin tensha no ichi mondai 發思巴文母音轉寫の一問題', Jimbun Kenkyu (Ō saka City University), XIX, 10 (1968), pp. 22-33.

- - 'The $h \mathrm{P}$ 'ags-pa transcription of Chinese plosives', $M S$, XXVI (1957), pp. 149-74.

HASUMI, Shigeyasu 莲賽重康, 'Liang K'ai hitsu “Li Po yin-hsing t'u" no Pasupamoji “Ta-ssu-t'u-yin” to Aniko ni tsuite 梁楷筆「李白吟行圖」の 八思巴交字「大司徒印」と阿尼哥飞就いて”, THG, 35 (1968), pp. 83-97.

HATTORI, Shirō 服部四郎, Genchōhishi no Mōkogo o arawasu Kanji no Kenkyu 元朝祕史の蒙古語を表はす漢字の研究 (Tokyo：Ryūbun Syokyoku, 1946) iv +146 pp. esp. pp. 36-58, 66-73.

- - 'Genchōhishi onyaku genten Pasupaji-bon setsu ni tsuite 元朝就史 昔譯原典八思巴字本說に就いて’, $G K, 19 / 20$ (1951), pp. 120-1.

- - , 'Genchōhishi genten no mondai ni tsuite 元朝䋅史原典の問題飞就いて’, GK, 25 (1954), pp. 52-9.

- - , 'Pasupaji パスパ字’, Sekai Daihyakka Jiten 世界大百科事典, vol. XXIII (Tokyo: Heibonsha, 1958), p. 226b.

HEISSIG, W., Die Pekinger lamaistischen Blockdrucke in mongolischer Sprache. Materialien zur mongolischen Literaturgeschichte (=Göttinger Asiatische Forschungen, II) (Wiesbaden: O. Harrassowitz, 1954), pp. 159-60.

- - Mongolische Handschriften $\cdot$ Blockdrucke $\cdot$ Landkarten (=Verzeichnis der Orientalischen Handschriften in Deutschland, Band I) (Wiesbaden: F. Steiner, 1961), p. 31.

- - Beiträge zur Übersetzungsgeschichte des mongolischen buddhistischen Kanons ( $=$ Abhandlungen der Akademie der Wissenschaften in Göttingen, Philologisch-historische Klasse, III, 50) (Göttingen: Vandenhoeck \& Ruprecht, 1962), pp. 7-8.

HODGSON, B.H., 'Notices of the Languages, Literature, and Religion of Bauddhas of Nepal and Bhot', Asiatic Researches, vol. XVI (1828), Article No. XII, pp. 409-49, esp. the 3rd plate after p. 420. HOPE, E.R., Karlgren's Glottal Stop Initial in Ancient Chinese, with par. 
ticular reference to the hPhags-pa alphabet and to certain points of linguistic psycholoy (Ottawa: published by the author, 1953), xii $+89 \mathrm{pp}$. Reviews and replies:

a) SERRUYS, P.L.M., Oriens, VIII(1955), pp. 135-41.

b) HOPE, E. R., Oriens, IX (1956), pp.295-6 [Answer to Serruys]

c) SERRUYS, P.L.M., Oriens, IX (1956), p. 296. [Rejoinder]

d) WHINNOM, K., JOS, II (1955), pp. 158-72.

- - 'Letter shapes in Korean Önmun and Mongolian hPhagspa alphabet', Oriens, X (1957), pp. 150-9.

HUTH, G., 'Note préliminaire sur l'inscription de Kiu-yong Koan, IV. Les inscriptions mongoles', $J A$, IX, 5 (1895), pp. 351-60.

IMBAULT-HUART, C., 'Note sur l'inscription bouddhique à la passe de Kiu-yong Kouan', Revue de l'Extrême Orient, II, 4 (1883), pp. 486-93. ISHIDA, Mikinosuke 石田幹之助, 'Mōko moji no kigen to enkaku 蒙古文 字の起原と沿革”, Tōa, III, 12 (1930), pp. 84-92.

JENSEN, H., Geschichte der Schrift (Hannover, 1925), pp. 119-217.

KANAOKA, Shūyū 金岡秀友, 'Mōko moji no seitei to Bukkyōsō no kankei 蒙古文字の制定と佛教僧の閣係'，Ōkurayama Gakuin Kiyō (Yokohama), I (1954), pp. 141-48.

KANSAI DAIGAKU TŌZAI GAKUJUTSU KENKYÜJO 關西大學東西學術 研究所, Eiin Daiei Hakubutsukan zō Kyūshōhon Mōkojiin 影印大英博 物館藏舊鈔本蒙古字韻 (Osaka：Kansai University, 1956), 128 pp.

KARA, G., 'Un texte mongole en écriture soyombo', $A O H, \mathrm{IX}(1959)$, pp. 1-38, esp. pp. $1,4-5$.

KLAPROTH, J., Abhandlung über die Sprache und Schrift der Uiguren (Berlin, 1812)

KOBAYASHI, Takashirō 小林高四郎, 'Kanji onyaku Genchōhishi Pasupajibon genten setsu ni tsuite 漢字亘譯元朝北史八思巴字本原典說に就いて’, Katō Hakushi Kanreki Kinen Tōyōshi Shūsetsu 加藤博士還曆記念東洋史 集說 (Tokyo: Fuzanbō, 1941), pp. 289-309.

- - Genchōhishi no Kenkyū 元朝秘史の研究 (Tokyo：Nihon Gakujutsu Shinkōkai, 1953), pp. 281-305, 307-9.

KOTWICZ, W., 'Quelques données nouvelles sur les relations entre les Mongols et les Ouigour', RO, II (1919/1924), pp. 240-7.

- -, 'Formules initiales des documents mongoles aux XIII-e et XIV-e 
ss.', $R O, \mathrm{X}$ (1934), pp. 131-57.

- - Quelques mots encore sur les lettres des il-khans de Perse retrouvées par Abel-Rémusat', RO, XVI (1953), pp. 405-27. [First published in Collectanea Orientalia, No. 10 (1936), 22 pp.]

KRADER, L., 'Qan-Qayan and the beginnings of Mongol kinship', $C A J$, I (1955), pp. 17-35, esp. p. 31.

LACOUPERIE, T. de, Beginnings of Writing in Central and Eastern Asia, or Notes on 450 Embryo-Writings and Scripts (London, 1894, repr. Osnabrück: O. Zeller, 1965), pp. 76-7, 173.

LANE-POOLE, S., The Coins of the Mongols in the British Museum (= Catalogue of Oriental Coins in the British Museum, vol. VI) (London, 1881, repr. 1967), $1 \times x v+300$ pp. +9 plates, esp. pp. xlix-lii.

LANG, D.M., Studies in the Numismatic History of Georgia in Transcaucasia (New York, 1955), pp. 52-4.

LAUFER, B., 'Skizze der mongolischen Literatur', $K S z$, VIII (1907), pp. 160̄-261, esp. pp. 183-6.

LEWICKI, M., Les inscriptions mongoles inédites en écriture carrée $(=C o l$ lectanea Orientalia, No. 12) (Wilno, 1937), 72 pp.

- - La Langue mongole des transcriptions chinoises du XIVe siècle. Le Houa-yi yi-yu de 1389, I ( = Prace Wroctawskiego Towarzystwa Naukowego, A 29) (Wrocław, 1949), 225 pp.; II (=ibid., A 60)(Wrocław, 1959), 89 pp.

I. reviewed by N.N. Poppe, JAOS, LXXI (1951), pp. 187-92.

II. reviewed by J. Chmielewski, RO, XXIII, 1 (1959), pp. 101-4.

LI, Te-ch'i 李德啓, 'Man-chou wen-tzu chih lai-yüan chi ch'i yen-pien 㴖 洲支字之來源及其演變”， PPTSK, V, 6 (1931)，pp. 1-18.

LIGETI, L., 'A 'Phags-pa irásos nyelvemlékek [=Les documents en écriture 'phags-pa]', Emlékkönyv Melich János hetvenedik születésenapjára [= Mélanges offerts à M.J. Melich à l'occasion de son $70^{e}$ anniversaire] (Budapest, 1942), pp. 222-37.

- -, 'Le chinois en écriture 'phags-pa', Actes $21^{e}$ Congrès Orientaliste (Paris, 1949), p. 262.

- - 'Mots de civilisation de Haute Asie en transcription chinoise', $A O H$, I (1950), pp. 141-88, esp. p. 155.

- - 'Le Po kia sing en écriture 'phags-pa', $A O H$, VI (1956), pp.1-52. 
- - 'Trois notes sur l'écriture 'phags-pa', $A O H$, XIII(1961), pp. 201-37.

- - 'Les fragments du Subhāṣitaratnanidhi mongole en écriture 'phagspa', $A O H$, XVII (1964), pp. 239-92.

LO, Ch'ang-p'ei 羅常培 and TS'AI, Mei-piao 蔡美㱆, Pa-ssu-pa-tzu yüi Yüantai Han-yü 八思巴字與元代漢語(資料鲳編) (Peking: K'o-hsüeh Ch'u-panshe, 1959), 128 pp. +30 plates.

LO, Ch'ang-p'ei, 'Lun Lung Kuo-fu te Pa-ssu-pa-tzu ho Ku-Kuan-hua 論 龍果夫的《八思巴字和古官話》’, $Z Y, 90$ (1959), pp. 575-81. [Repr. in $L_{0}$ Ch'ang-p'ei Yü-yen-hsüleh Lun-wen Hsüan-chi 羅常培語言學論交選集 (Peking: Chung-hua Shu-chü, 1963), pp. 184-94.]

LU, Chih-wei 陸志韋, 'Shih CYYY 釋中原音韻', YCHP, XXXI (1946),pp. 35-70.

MOSTAERT, A. and CLEAVES, F.W., "Trois documents mongole des Archives Secrètes Vaticanes,' HJAS, XV (1952), pp. 419-506+8 plates.

MURATA, Jirō 村田治郎 (ed.), Kyoyökan 居庸閣 (Kyoto： Kyoto University, 1957), II, plates 59-63, 91-2.

MURAYAMA, Shichirō 村山七郎, “Über die Annahme, dass der chine. sischen Transkription der Geheimen Geschichte der Mongolen ein Original in hP'ags-pa Schrift zugrunde liege', $G K, 24$ (1953), pp. 12-47.

NAKANO， Miyoko 中野美代子, 'Mōkojiin no kenkyū — On'inshi teki kōsatsu — 蒙古字䫓の研究——音韻史的考察', $H D G G K, \mathrm{XI}$ (1964), pp. 15-37. [Repr. in CKRS, I (1965), pp. 247-58.]

- -, 'Rgya-dkar-nag rgya-ser ka-smi-ra bal bod hor-gyi yi-ge dar dpe-ris rnam-grañs man்-ba ni tsuite —- Pasupaji to sono shūhen — Rgyadkar-nag...について—パスパ字とその周邉”, THG, 36(1968), pp. 149-134 (1-16). [English tr.: 'The Rgya-dkar-nag......and some remarks on the 'Phags-pa script', Indo-Asian Studies, vol. 3 (1971), pp. 1-16.]

NOMURA, Masayoshi 野村正良, 'Mokogo 蒙古語', Sekai Gengo Gaisetsu 世界言語概說, vol. II (Tokyo: Kenkyūsha, 1955), pp. 537-90.

OSHIBUCHI, Hajime 駕淵一, 'Chūgen On'in chū no Pasupaji nite utsusaretaru Kanjion ni tsuite 中原吾䫓中の八思巴字にて窞されたる漢字音に 就いて’, Ogawa Hakushi Kanreki Kinen Shigaku Chirigaku Ronsō 小川博士還曆記念史學地理學諭叢 (Kyoto: Kōbundō, 1930), pp. 601-41.

- - 'Pasupa moji ni shirusaretaru Gendai Kanjion ni tsuite 八思巴文 字に記されたる元代漢字音に就いて’, Shigaku Kenkyü (Hiroshima), I, 3 
(1930), pp. 480-1.

- - 'Pasupa moji ni tsuite 八思巴交字に就いて’, SZ, XLI, 7 (1930), pp. 854-5.

OZAKI, Y $\bar{u}$ jirō, 尾崎雄二郎, “Daiei Hakubutsukan-bon Mōkojiin sakki 大英博物館本蒙古字韻札記', Jinbun (Kyoto), VIII (1962), pp. 162-80.

OZAWA, Shigeo 小澤重男, 'Sansei-shō Kōjōken Sekiheki-zan Genchū-ji no Pasupamoji Mōkogo hibun no kaidoku 山西省交城縣石壁山去中寺の 八思巴文字蒙古語碑文の解讀', Tōkyō Gaikokugo Daigaku Ronshū 東京外 國語大學論集, 9 (1962), pp. 9-33+1 plate.

PALLAS, P.S., Sammlungen historischer Nachrichten über die mongolischen Völkerschaften (St. Petersburg: Kaiserl. Akad. der Wiss. 17761801), 2 vols.

PAUTHIER, G., 'Rapport sur deux médailles en cuivre jaune trouvées à Sourabaya, île de Java, dont les fac-similé lithographique ont été envoyés à la Société par M. Netscher, de Batavia', JA, V, 15 (1860), pp. 321-37+3 illustr.

- -, 'De l'alphabet de Pa'-sse-pa, et de la tentative faite par Khoubilai-Khan au XIII ${ }^{e}$ siècle de notre ère pour transcrire la langue figurative des chinois au moyen d'une écriture alphabétique,' $J A, \mathrm{~V}, 19$ (1862), pp. 5-47+4 tables.

PELLIOT, P., 'Sur quelques mots d'Asie centrale attestés dans les textes chinois', JA, XI, 1 (1913), pp. 451-69.

- - 'Un catéchism bouddhique ouigour écriture tibétaine', $J A$, XVIII, 1 (1921), pp. 135-6. [Brief summary of his report at the Asiatic Society of Paris.]

- - Review of F.E.A. Krause, Ju-Tao-Fo (see item of Krause), TP, XXIII (1924), pp. 54-62.

- - 'Les systèmes d'écriture en usage chez les anciens mongols', $A M$, II, 2 (1925), pp. 284-9.

- - Review of C. Bell, Tibet, Past and Present, TP, XXV (1928), pp. 139-48, esp. p. 142 , n. 1.

- - 'Sur l'origine de l'alphabet dit 'phags-pa', JA, CCX, 2 (1927), p. 372. [Brief summary of his report at the Asiatic Society of Paris.]

- - 'Un rescrit en écriture 《'phags-pa》', Tibetan Painted Scrolls (see item of Tucci), vol. II, pp. $621-4+2$ plates. 
- -, Notes sur l'Histoire de la Horde d'Or (=Oeuvres Posthumes de Paul Pelliot, II) (Paris: Adrien-Maisonneuve, 1949), pp. 59-61.

POPPE. N.N., Istorija Mongol'skoj pis'mennosti, vol. I=Kvadratnaja pis' mennosti (Moscow/Leningrad: Akademija Nauk SSSR, 1949), 167 pp. a) Japanese tr.: 'Hôkeiji 方形字', tr. by S. MURAYAMA and T. YAMASAKI, Nihon Bunka (Tenri University), 35 (1955), pp. 236-187 (1-50). [with N. N. Poppe's preface to the Japanese translation dated 2 April 1954.]

b) English tr. : The Mongolian Monuments in hִP'ags-pa Script (= Göttinger Asiatische Forschungen, 8), tr. and ed. by J.R. Krueger (Wiesbaden: O. Harrassowitz, 1957), xii 147 pp. +13 plates +1 map. [with a very rich bibliography by J. R. Krueger, ibid., pp. 134-42. (136 items).]

- - 'Die Sprache der mongolischen Quadratschrift und das Yüan-ch' ao pi-shi', $A M$, n.s. I, 1 (1944), pp. 97-115.

- - 'The groups *ura and *üge in Mongol languages', SO, XIV, 8 (1950), pp. 1-15.

- - Grammar of Written Mongolian (=Porta Linguarum Orientalium, n. s. I) (Wiesbaden: O. Harrassowitz, 1954), pp. 4-6.

RAMSTEDT, D.J., 'Mongolische Briefe aus Idiqut Schāhri bei Turfan', Sitzungsberichte der Königlichen Preussischen Akademie der Wissen. schaften, Philologisch-Historische Klasse, XXXII (1909), pp. 838-48.

- , 'Ein Fragment mongolischer Quadratschrift', JSFOu, XXVII, 3 (1911), pp. 1-4.

[English tr.: 'A fragment of Mongolian 'Quadratic' script', C.G. Mannerheim. Across Asia from West to East in 1906-1908 (Helsinki : Société Finno-Ougrienne, 1940), 5 pp.]

Rgya-dkar-nag rgya-ser ka-smi-ra bal bod hor-gyi yi-ge dan் dpe-ris rnam-

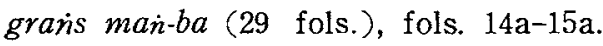

RINT(S)CHEN, 'Zwei unbekannte mongolische Alphabete aus dem XVII. Jahrhundert', $A O H$, II (1952), pp. 63-7+1 table +1 plate.

- 'A propos de la sigillographie mongole', $A O H$, III (1953), pp. $25-9+2$ plates.

ROERICH, G. N. de, 'Mun-mkhyen Čhos-kyi hod-zer and the origin of the Mongol alphabet', JASB, XI, 1 (1945), pp. 52-8. 
SCHIEFNER, A., 'Nachträge zu den von O. Böhtlingk und I. J. Schmidt verfassten Verzeichnissen der auf Indien und Tibet bezüglichen Handschriften und Holzdrucke im Asiatischen Museum der Kais. Akademie der Wissenschaften', Bulletin, V, 10 (1848), Sp. 146-7 (=No. 125aaa). SCHLÖSSER, R., 'Die Münzen der beiden Epochen Chi Yüan', Artibus Asiae, V, 1 (1935), pp. 38-46.

SCHMIDT, I. J., 'Über eine mongolische Quadratinschrift aus der Regierungszeit der mongolischen Dynastie Jüan in China', Bulletin, IV, 9 (1848), Sp. $129-41+1$ table.

SEKINO, Tei 關野真 and TOKIWA, Daijō 常盤大定, Shina Bukkyō Shiseki 支那佛敉史蹟 (Tokyo: Bukkyō Shiseki Kenkyūkai, 1928), vol. V, plates 128-30.

SHENG, Hsi-ming 盛熙明, Fa-shu k'ao 法書考（Ssu-pu Ts'ung-k'an ed.）, vol. 2, pp. 1b-3b.

SIMON, W., 'A $h$ Phags-pa seal of 1295', $A M$, n.s.VI, 2 (1958), pp. 203-5.

T'AO, Tsung-i 陶宗儀, Shu-shih Hui-yao 書史會要 (Ssu-k'u Ch'üan-shu ed.), vol. 7, pp. 27b-28a.

TERAMOTO, Enga 寺本婉雅, 'Kyoyōkan no hekibun oyobi sono chōkoku bijutsu ni tsuite 居庸關の壁文及其彫刻美術に就て'，SZ，XX，(1910),pp. 351-64; pp. 609-17 ; pp. 1514-16.

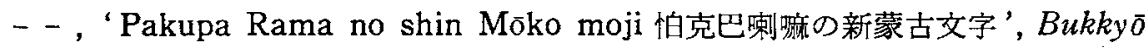
Shigaku, I; 11 (1912), pp. 917-34; ibid., II. 2 (1912), pp. 108-27.

- - Chibettogo Bunpō 西藏語文法 (Kyoto: Naigai Shuppan, 1923), pp.6-7, plate after the title page.

TS'AI, Mei-piao, 'Pei-ching Ta-hsüeh Wen-k'o Yen-chiu-so so-ts'ang Yüan Pa-ssu-pa-tzu pei-to hsü-mu 北京大學文科研究所所藏元八思巴字碑 拓序目', PCTH, VII, 3 (1930).

- - Yüan-tai Pai-hua-pei Chi-lu 元代白話碑集錄 (Peking: K'o-hsüeh Ch'u-pan-she, 1955), pp. 23-4, plate 4. [Cf. FENG, Ch'eng-chün 馮承鈞 Yüan-tai Pai-hua-pei k'ao 元代白話碑考(=Shih-ti Ts'ung-shu)(Shanghai : Commercial Press, 1933), 63 pp.]

- - ' 'Yung-chia fa-hsien Yüan-tai Meng-wen-yin k'ao-shih 永募發現元代 蒙文印考釋', WWTK, 89 (1958), pp. 42-3.

WADDELL, L.A., Lhasa and its Mysteries (London : J.Murray, 1905), p. 448.

Reviewed by S.W.:Bushell, JRAS, 1906, pp. 476-9. 
- - 'Seal of the Dalai Lama', Hasting's Encyclopaedia of Religion and Ethics (Edinburgh), IV (1911), pp. 204-6.

- , 'Seal of the Dalai Lama', JRAS, 1911, pp. 204-6.

- - 'The Dalai Lama's seal', JRAS, 1911, pp. 822-5.

WAISH, E.H.C., 'Coinage of Tibet', $M A S B$, II, 2 (1907), pp. 11-23+2 plates.

- , 'Seal of the Dalai Lama', JRAS, 1911, pp. 206-7.

- - 'Examples of Tibetan seals', JRAS, 1915, pp. 1-15; 'Examples of Tibetan seals: Supplementary note', ibid., pp. 465-70.

WANG, Ching-ju 王静如, 'Shih Ting-hai Fang-shih so-ts'ang ssu-t'i-tzu Chih-yüan t'ung-pao ch'ien-wen 釋定海方氏所藏四體字至元通寶錢交', $A S$, III, 2 (1931), pp. 277-8.

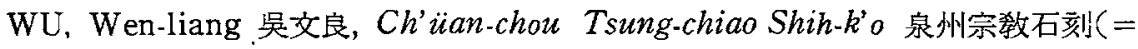
K'ao-ku-hsüeh Chuan-k'an, I-chung, No. 7) (Peking: K'o-hsuieh Ch'upan-she, 1957), pp. 33-4, plates 85-7.

WYLIE, A., 'On an ancient inscription in the Neuchin language', JRAS, XVII, 16 (1860), pp. 331-45.

- - ' Remarks on some impressions from a lapidary inscription at Keuyung-kwan, on the Great Wall near Peking. Fac-similes exhibited', Journal of the North China Branch of the Royal Asiatic Society, n.s. I (1860), pp. 133-6.

- - , 'Sur une inscription mongole en caractères $\mathrm{Pa}^{\prime}$-sse-pa', $J A, \mathrm{~V}, 19$ (1862), pp. $461-71+1$ plate.

- -., 'On an ancient Buddhist inscription at Keu-yung kwan, in North China', JRAS, n. s. V, 1 (1870), pp. 14-44.

- -, 'On an ancient inscription in Chinese and Mongol, from a stone tablet at Shanghai', Transactions of the China Branch of Royal Asia. tic Society (Hong Kong), n.s. part V, article No. III (1885), pp.65-81.

- - , Notes on Chinese Literature, with Introductory Remarks on the Progressive Advancement of the Art (Shanghai: American Presbyterian Mission Press, 1901), p. 187.

YAMASAKI, Tadashi 山崎忠, '1318-nen no Pasupaji Mōkogo hibun kaidoku, 1318 年の八思巴字蒙古語碑文解讀’, $G K, 26 / 27(1954), p p .111-9$.

YANAI, Wataru 箭內亘, 'Genchō haifu kō 元朝牌符考', Mōkoshi Kenkyū 蒙古史研究 (Tokyo：Tōkō Shoin, 1930), pp.839-98, esp. plates facing 
pp. $870,894$.

YANG, Nai-ssu 楊耐思, 'Pa-ssu-pa-tzu tui-yin—-tu Lung Kuo-fu Pa-ssupa-tzu yü Ku-kuan-hua hou一一八思巴字對豆一一頒龍果夫《八思巴字與古官 話》後', $Z Y, 90$ (1959), pp. 582-4, 587.

YULE, H. (tr. and ed.), The Book of Ser Marco Polo, the Venetian con. cerning the Kingdoms and Marvels of the East (London: J. Murray, 1903), I, pp. 351-6 (=Book VII, Chapter VII, note 2), plate facing p. 352.

YUYAMA, Akira 湯山明, Indic Manuscripts and Chinese Blockprints (Non-

Chinese Texts) of the Oriental Collection of the Australian National University Library, Canberra (=Occasional Paper, 6) (Canberra : Australian National University, 1967), pp. 84-100.

\section{Chinese Language, in particular Middle Chinese.}

ARISAKA, Hideyo 有坂秀世, 'Nisshō inbi shōshitsu no katei 入聲韻尾消 失の過程', Kokugo On'inshi no Kenkyu 國語晋韻史の研究(堵補新版) (Tokyo: Sanseidō, 1957, rev. and 2nd ed.), pp.601-7. [First published in Onseigaku Kyōkai Kaihō 畐聲學協會會報, 41 (1936).]

- - 'Fugin no Tō-on ni han'ei shita Kamakura jidai no on'in jōtai 諷 經の唐亘に反映した鎌倉時代の音韻狀態'，ibid., pp. 185-220. [First published in $G K, 2$ (1939).]

- ' 'Mei, nei no tagui wa hatashite Kan-on narazaruka ? メイ(明)ネ イ(害)の類は果して漢音ならざか’, ibid., pp. 369-74. [First published in Onseigaku Kyōkai Kaihō, 64 (1940).]

CHANG, Ping-lin 章丙麟, 'Ku-yin niang jih erh-niu kuei ni shuo 古晋娘日 二紐歸泥說', Chang-shih Ts'ung-shu 章氏叢書 (Taipei: Shih-chien Shuchü, 1958, based on the Chekiang Library ed.), vol. I, pp. 30b-33a.

CHAO, Hsia-ch'iu 趙遐秋 and TSENG, Ch'ing-jui 曾磨瑞, 'CYYY yinhsi te chi-ch'u ho ju-p'ai san-sheng te hsing-chih 中原晋韵曋系的基礎 和 '入派三聲” 的性質', $Z Y, 117$ (1962), pp. 312-24.

CHAO, Yuen-ren 趙元任, Hsien-tai Wu-yü te Yen-chiu 現代吳語的研究 (=Tsing Hua College Research Institute Monograph, No.4) (Peking :

Tsing Hua College Research Institute, 1928), xv +135 pp.

- - , 'Lun ch'ing-cho 諭清濁’, AS, IV, 2 (1959), pp. 493-7. 
CHAO, Yin-t'ang 趙院棠, CYYYYen-chiu 中原音韻研究 $(=$ Kuo-hsüeh Hsiao. ts'ung-shu) (Shanghai : Commercial Press, 1936), 298 pp.

- - , Teng-yün Yüan-liu 等韻源流 (Shanghai: Commercial Press, 1957), $342 \mathrm{pp}$.

CHENG, Tsai-fa, 'Han-yü yin-yün-shih te fen-ch'i wen-t'i 漢語音韻史的分 期問題', $A S, \mathrm{XXXVI,} 2$ (1966), pp. 635-48.

CH'IEN, Ta-hsin 錢大所, Shih-chia-chai Yang-hsin-lu 十駕唯養新錄, vol. 5 (Chia-ting Ch'ien-shih Ch'ien-yen-t'ang Ch'üan-shu 嘉定錢氏潜研堂全 書).

CHOU, Te-ch'ing 周德清, Chung-yüan Yin-yün 中原晋韻, See III : HattoriTōdo and Hsü Shih-ying.

CHOU, Tsu-mo 周祖謨, 'Sung-tai Pien-Lo yü-yin k'ao 尔代汴洛語音考', FJHC, XII, 1/2 (1943), pp. 221-85. [Repr. in Han-yü Yin-yün Lunwen-chi 漢語音韻論文集 (Shanghai : Commercial Press, 1957),pp. 189-235.]

CHU, Tsung-wen 朱宗文, Meng-ku Tzu-yün 蒙古字韻. See II : Kansai Daigaku and Lo.Ts'ai.

CSONGOR, B., 'Chinese in the Uighur script of the T'ang-period ', $A O H$, II (1952), pp. 73-121.

- ' 'Some Chinese texts in Tibetan script from Tun-huang', $A O H$, $X(1960)$, pp. $97-140$.

FORREST, R. A. D., 'The ju-sheng tone in Pekinese', BSOAS, XIII(1949), pp. $443-7$.

HANEDA, Tōru, 'Kan-Ban taion Senjimon no dankan 漢藩對音千字文の斷 簡', Haneda Hakushi Shigaku Ronbunshū, II (= Gengo, Shükyōhen) (Kyoto: Kyoto University, 1958), pp. 396-419, plate 11. [First published in TYGH, XIII, 3 (1923), pp. 390-410+3 plates.]

HARTMANN, L. M., 'The segmental phonemes of Peiping dialect', Lan. guage, XX (1944), pp. 28-42.

HASHIMOTO, Mantarō, J., Phonology of Ancient Chinese (Ann Arbor : University Microfilms Inc., 1966), 734 pp. [Ph. D. Thesis presented to the Ohio State University, 1965.]

HATTORI, Shirō and TŌDŌ Akiyasu, 藤堂明保, Chūgen On'in no Kenkyū 中原音韻の研究(校本篇) (Tokyo: Kōnan Shoin, 1958), 266 pp. +facsimile of the T'ieh-ch'in T'ung-chien-lou ts'ang Yüan-k'an CYYY 鐵琴銅劍! 樓藏元刊中原音韻. 
HIRAYAMA, Hisao 平山久雄, 'Chūko nisshō to Pekingo seichō no taiō tsūsoku 中古入聲と北京語聲調の對應通則', $N C G H, \mathrm{XII}(1960)$, pp. 139-56. HOCKETT,C. F., 'Peiping morphophonemics', Language, XXVI (1950), pp. 63-85.

- - ' 'Peiping phonology', JAOS, LXVII (1947), pp. 253-67.

HSÜ, Mu-yün 徐慕雲 and HUANG, Chia-heng 黄家衡, Ching-chü Tzu-yün 京劇字韻 (Shanghai : Shanghai Wen-i Ch'u-pan-she, 1963), pp.67-80.

HSÜ, Shih-ying 許世英 and LIU, Te-chih 劉德智, Yin-chu CYYY 亘洼中 原音䫄 (Taipei : Kuang-wen Shu-chü, 1962), $55+5$ fols.

KARLGREN, B., Etudes sur la phomologie chinoise $(=$ Archives d'Etudes Orientales, vol. 15) (Uppsala: Appelberg, 1915-1924), 898 pp. [Chinese tr. : Kao Pen-han 高本漢 (Karlgren), Chung-kuo Yin-yün-hsüeh Yen-chiu 中國音韻學研究, tr. by CHAO, Yuen-ren, LO, Ch'ang-p'ei and LI, Fangkuei (Shanghai : Commercial Press, 1940), 731 pp.]

- -, 'Prononciation ancienne de caractères chinois figurants dans les transcriptions bouddhiques', TP, XIX (1920), pp. 104-21.

- - Analytic Dictionary of Chinese and Sino-Japanese (Paris: P. Geuth. ner, 1923), $436 \mathrm{pp}$.

- - Grammata Serica Recensa (= The Museum of Far Eastern Anti. quities Stockholm Bulletin, No. 29) (Stockholm: Museum of Far Eastern Antiquities, 1957), 332 pp.

KEIYA, Toshinobu 璴谷鲞信, 'Nisshō inbi shōshitsu no katei ni tsuiteno ichi kasetsu —Mōkojiin karano apurōchi - 入聲韻尾消失の過程につ いての一假設一一蒙古字韻からのアプローチ’, NDBKR, XXXVII (1965). pp. 1-37. [Repr. in CKRS, II. (1965), pp. 14-32.]

- ', 'Pei-yin ju-sheng yen-pien $k$ 'ao fusetsu 北音入聲演變敃附說'， NDBKR, XL (1966), pp. 45-110.

- - 'Nisshō inbi shōshitsu ni kansuru ichi mondai 入聲䁚尾の消失に關 する一問題', Kotoba, XXXIV (1966), pp. 15-37.

-. ' 'Onsetsu kōsei to on' in henka-Kohoku hōgen ni okeru nisshō inbi shōshitsu no katei一音箅構成と音韻變化一一湖北方言における人聲 韻尾消失の過程', NDBKR, XLIII (1967)，pp. 17-49.

LAUFER, B. , 'Chinese transcriptions of Tibetan Names', TP, XVI(1915), pp. $420-4$.

LI, Jung 李榮, 'Huang-chi Ching-shih shih-sheng shih-erh-yin chieh 皇極經 
世十聲一二音解', Ch'ieh-yün Yin-hsi 切韻昔系 (=Yü-yen-hsüeh Chuan$k^{\prime} a n$, No. 4) (Peking: Chung-kuo K'o-hsüeh-yüan, 1952), pp. 165-74. LIAO, Hsün-ying 沗珣英, 'Chu-kung-tiao te yung-yün 諸宮調的用韵', $Z Y$, 128 (1964), pp. 19-27.

LO, Ch'ang-p'ei, 'Yeh-su-hui-shih tsai yin-yün-hsüeh shang te keng-hsien 耶蘇會士在夏韵學上的貢獻’, $A S, \mathrm{I}, 3(1930), \mathrm{pp} .267-338$.

- - , 'CYYY sheng-lei k'ao 中原音韻䠛類考', $A S$, II, 4 (1932), pp. 423-40.

[Repr. in Lo Ch'ang-p'ei Yü-yen-hsüeh Lun-wen Hsüan-chi (Peking: Chung-hua Shu-chü, 1963), pp. 65-79.]

- - ' Chih ch'e ch'eng niang yin-chih k'ao 知徹澄娘昔值考', $A S$, III, 1 (1931), pp. 121-57. [Repr. ibid., pp. 22-53.]

- - 'Fan-wen o-yin wu-mu te Tsang-Han tui-yin yen-chiu 梵文頢音五 母的藏漢對亘研究', AS, III, 2 (1931), pp. 263-76. [Repr. ibid., pp. 54-64 +1 table. $]$

- - , T'ang Wu-tai Hsi-pei Fang-yin 唐五代西北方晋 （=The National Research Institute of History and Philology Monographs Series $A$, No.

12) (Shanghai: Academia Sinica, 1933), 223 pp.

- - Hsia-men Yin-hsi 厦門晋系 (=Academia Sinica Monograph, No. 4)

(Peiping: Academia Sinica, 1930, repr. Peking 1956), ix +286 pp.

LU, Chih-wei, 'Chi Shao Yung HCCS te t'ien-sheng ti-yin 記邵雍皇極經 世的天馨地音', YCHP, XXXI (1946), pp. 71-80.

- - , 'Chi Lan Mao Yün-lüeh I-t'ung 記藍茂韻略易通', YCHP, XXXII (1947), pp. 161-8.

- , 'Chi Hsü Hsiao Ch'ung-ting Ssu-ma Wen-kung Teng-yün T'u-ching 記徐孝重訂司馬溫公等韻圖經', YCHP, XXXII (1947), pp. 169-96.

- - ' 'Chi Pi Hung-chen Yün-lüeh Hui-t'ung 記畢洪宸贑略監通', YCHP, XXXIII (1947), pp. 105-13.

- - ' Chin Ni-ko Hsi-ju Erh-mu-tzu so-chi te yin 金尼閣西需耳目資所記 的竟', YCHP, XXXIII (1947), pp. 115-28.

- - 'Chi Wu-fang Yüan-yin 記五方元音', YCHP, XXXIV (1948), pp. $1-13$.

- - , 'Kuo-yü ju-sheng yen-pien hsiao-chu 國語入䠛演變小泩', $Y C H P, \mathrm{XXX}$ IV (1948), pp. 21-8.

MARTIN, S., 'Problems of hierarchy and indeterminacy in Mandarin phonology', $A S, \mathrm{XXIX,} 1$ (1957), pp. 209-29. 
MASPERO, H., 'Le dialecte de Tch'ang-ngan sous les T'ang', BEFEO, XX, 2 (1920), pp. 1-124.

MIZUTANI, Shinjō 水谷負成, “Tōdai ni okeru Chũgokugo gotōbion no denasalization shinkō katei 唐代における中國語語頭鼻晋の denasalization 進行過程', TYGH, XXXIX, 4 (1957), pp. 1-31.

NAGASHIMA, Eiichirō 永島榮一郎, 'Kinsei Shinago tokuni Hoppōgo keitō ni okeru on'inshi kenkyü shiryō ni tsuite 近世支那語特k北方語系統 に於ける晋䫓史研究資料化就いて’，GK,7/8 (1941)，pp. 147-61；ibid, , 9 (1941), pp. 17-79.

OGAWA, Tamaki 小川環樹, ' $N i$ to erh oyobi $j i h-m u$ no seiritsu 儞と爾 及び日母の成立’, $G K, 24$ (1953), pp.7-11.

- - , 'Su Tung-p’o koshi yōin kō 蘇東坡吉詩用韻考”, Kyōto Daigaku Bun. gakubu Gojisshūnen Kinen Ronshū 京都大學文學部五十周年記念論集 (Kyoto: Kyoto University, 1956), pp. 843-70.

- , “"Nanchō yonhyaku hasshinji” no yomikata 南朝四百八十寺の讀み方”, Onsei Kagaku Kenkyü 晋聲科學研究 (Kyoto), I (1961), pp. 29-36.

OSADA, Natsuki 長田夏樹, 'Soshūgo on'in taikei no shotokuchō ni tsuite 蘇州語音䫓體系の諸特徵について’, CGKR, I (1953), pp. 35-50.

ŌTOMO, Shin'ich 大友信一, Muromachijidai no Kokugo Onsei no Kenkyū 室町時代の國語吾聲の研究 (Tokyo：Shibundo, 1963), pp. 67-88.

PEI-CHING TA.HSÜEH YÜ-YEN-HSÜEH CHIAO-YEN-SHIH 北京大學語 言學敉研室, Han-yü Fang-yin Tzu-hui 漢語方音字龨 (Peking: Wen-tzu Kai-ko Ch'u-pan-she, 1962), 272 pp.

PELLIOT, P., 'Quelques transcriptions chinoises de noms tibátains', $T P$, XVI (1915), pp. 1-26.

PO, Ti-chou 白滌洲, 'Pei-yin ju-sheng yen-pien k'ao 北昔入聲演變攻', NSTH, II, 2 (1931).

PULLEYBLANK, E.G., 'The consonantal system of Old Chinese. part. II', $A M$, IX, 2 (1963), pp. 206-65.

- - 'The Chinese name for the Turks', JAOS, LXXXV, 2 (1965), pp. 121-5.

RAI, Tsutomu 賴惟勤, 'Jōko Chūgokugo no kōtō inbi ni tsuite 上古中國 語の堠頭韻尾について’, OJDG, III (1953), pp. 51-64.

RYGALOFF, A. , 'La phonologie du Pékinois', TP, XLIII (1955), pp.183-264.

SAKAI, Ken'ichi 坂井健-, 'Sōshi ōinji ni mirareru on'injō no ichi ni no 
tokushoku 宋詞押韻字に見られる晋䫓上の一二の特色”, TYGH，XXXVIII， 2 (1955), pp. 85-113.

SERRUYS, P. L. M. , 'Chinese dialectology based on written documents', $M S$, XXI (1962), pp. 320-44.

SIMON, W., 'A note on Chinese texts in Tibetan transcription', BSOAS, XXI (1958), pp. 334-43.

- , 'The China Illustrata Romanisation of João Soeiro's (Soerio's) Sanctae Legis Compendium and its Attribution to Michael Boym', Studia Serica Bernhard Karlgren Dedicata (Copenhagen: E. Munks. gaard, 1959), pp. 265-70+4 plates.

STIMSON, H. M., 'Ancient Chinese $-p,-t,-k$ endings in the Peking dialect', Language, XXXVIII (1962), pp. 376-84.

- - The Jongyuan In Yunn (=Sinological Series, No. 12) (New Haven: Far Eastern Publications of Yale University, 1966), $485 \mathrm{pp}$.

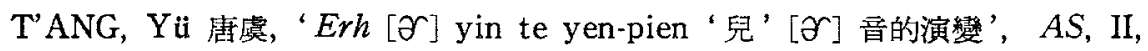
4 (1932), pp. 457-67.

THOMAS, F. W. and CLAUSON, G. L. M., 'A Chinese Buddhist text in Tibetan writing', JRAS, 1926, pp. 508-26.

- - 'A second Chinese Buddhist text in Tibetan characters', JRAS, 1927, pp. 281-306, 858-60.

TōDŌ, Akiyasu, 'Kànwa no seiritsu katei kara mita Seiju Jimokushi 官 話の成立過程加ら見た西儒耳目資'，THG，5 (1952)，pp. 99-122.

- - , Chügokugo On'inron 中國語音䫓論 (Tokyo: Kōnan Shoin, 1957), 358 pp.

- ' ' $K i$ - to tsi- no kondō wa 18 seiki ni hajimaru, ki.とtsi-. の混同は 18 世紀飞始まろ’, CG, 94 (1960),pp. 1-3, 12.

- - 'Development of Mandarin from 14c. to 19c.' $A A$, VI (1964),pp. $31-40$.

WANG, Li 王力, Han-yü Yin-yün-hsüeh 漢語昔喟學 (Peking: Chung-hua Shu-chü, 1956), $\mathrm{x}+682 \mathrm{pp}$.

- - , Han-yü-shih-kao 漠語定稿, vol. I (Peking: K'o-hsüeh Ch'u-panshe, 1957), $209 \mathrm{pp}$. 


\section{POSTSCRIPT}

After this monograph had been completed, a number of articles became available. Particularly important ones are as follows:

1. FARQUHAR, D.M., 'The Official Seals and Ciphers of the Yüan Period', MS, XXV (1966), pp. 362-93+36 figs.

2. HASHIMOTO, M.J., 'The $h \mathrm{P}$ 'ags-pa Transcription of Chinese Plosives', MS, XXVI (1967), pp. 149-74.

3. PULlEYBLANK, E. G., 'Note of the $h$ P'ags-pa Alphabet for Chinese', $A M(=W . B$. Henning Memorial Volume) (1970), pp. 358-75.

4. KRUEGER, J. R., 'Three Oirat-Mongolian Diplomatic Documents of 1691', CAJ, XII, 4 (1969), pp. 288-95.

Farquhar provides a number of materials of 'Phags-pa seals. His figure 20 is, as he says, especially of interest 'for being the only known text in a Turkic language written with the 'Phags-pa script' (p. 388). In 'Appendix : 'Phags-pa Materials' above, I have listed only one item written in a language other than Chinese, Mongolian, and Tibetan. Thus the 'Phags-pa Turkic seal is now to be added to my list as new material with some other 'Phags-pa Chinese seals introduced by Farquhar.

I was also unable to consult Hashimoto's article, although it is listed in my bibliography. It deals in great details with alternation between voiced and voiceless initial consonants in 'Phags-pa Chinese documents, which I have also treated in Chapter III. I have tried to clarify the puzzle of the alternation from a viewpoint of 'phonological opposition'; on the other hand Hashimoto bases his argument on a much more exhaustive phonetical viewpoint.

Pulleyblank deals with the value of the letters $e$ and $o$, the representation of the 'muddy' initials, and the initials ying, $y \ddot{u}$ and $i$, some of which are also mentioned in my paper.

As to Krueger, I wrote a commentary on his reading of The Great Seal of Galdan Boshogtu Khan, stamped on the letter to the Russian 
Czar from the Oirat Khan, Galdan in 1691 . It is expected to be published in CAJ, XIII, 1 (1971). As regards 'Phags-pa Chinese seals, I have also re-examined $\mathrm{E}$. Haarh's reading of three 'Phags-pa Chinese seals. My article entitled 'Three 'Phags-pa Seal Inscriptions - Reexamination of Dr. E. Haarh's Readings', will be published in $A M$, XVI, 1 (1971), pp. 6-101.

I regret $I$ was unable to revise this monograph after referring to these articles.

After finishing this monograph, I wrote a small book on the same subject for general readers, Sabaku ni uzumoreta Moji-Pasupamoji no Hanashi一砂漠に埋れな文字一パス八交字のはなしー (Script buried in Desert: A Story of the 'Phags-pa Script) soon to be published in Japan. In this book, I have advanced or abandoned some of the ideas in this monograph; in particular I have dealt historically with the social roles of the 'Phags-pa script amongst Mongolian and Chinese bureaucrats in the Yüan court and the meaning of the 'returning' of the 'Phags-pa script to Tibet.

Sapporo, April, 1971

M. N. 